
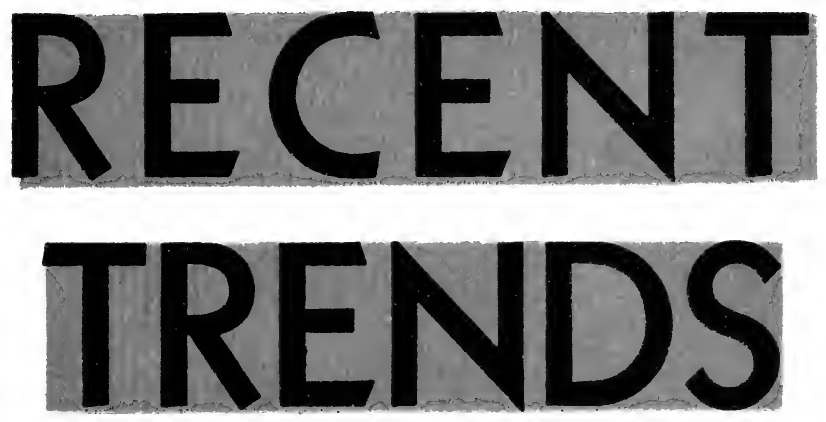

IN
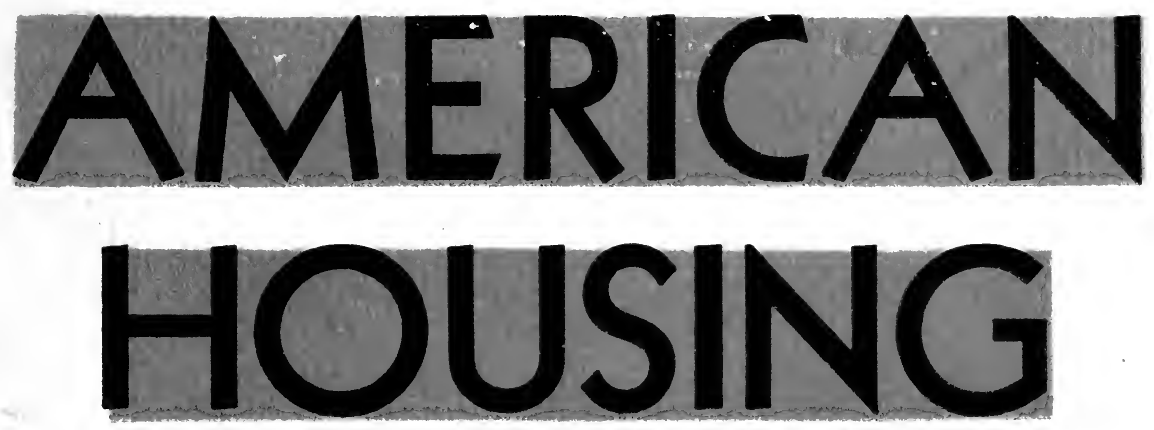

EDITH ELMER WOOD, Ph.D. Author of "The Housing of the Unskilled Wage Earner," etc. 


\section{RECENT TRENDS IN}

\section{AMERICAN HOUSING}

\section{By}

EDITH ELMER WOOD, Ph.D.

Author of

"The Housing of the Unskilled

Wage Earner," etc.

\section{ILLUSTRATED}

In her earlier book-"The Housing of the Unskilled Wage Earner" -Dr. Wood presented an authoritative and comprehensive array of facts concerning housing conditions up to 1919.

In this new book she takes up modern trends in American housing, having first made a careful summary of housing evils and their remedies up to 1917. This book is filled with startling statistics, comparisons, and statements which should shake us still further out of our lethargy about housing conditions in this country. Dr. Wood is interested both in restrictive and constructive housing measures, but she emphasizes the need of making better homes available to a larger percentage of people-the constructive policy.

THE MACMILLAN Publishers 
From the collection of the

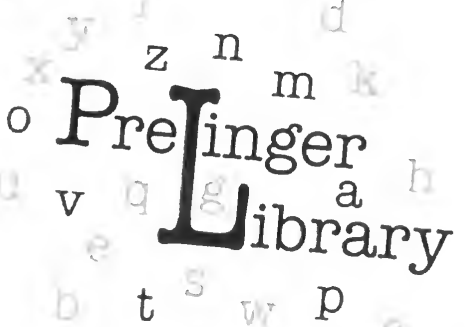

San Francisco, California 2006 
in

ti)

cr

to

m

h.

o

I

W

al

U

a

c

b

h

8

h

C

1 


\section{RECENT TRENDS IN AMERICAN HOUSING}




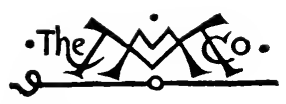

THE MACMILLAN COMPANY NEW YORK - BOSTON - CHICAGO - DALLAS ATLANTA - SAN FRANCISCO

MACMILLAN \& CO., Limited LONDON - BOMBAY - CALCUTTA MELBOUR NE

THE MACMILLAN COMPANY OF CANADA, Limited TORONTO 



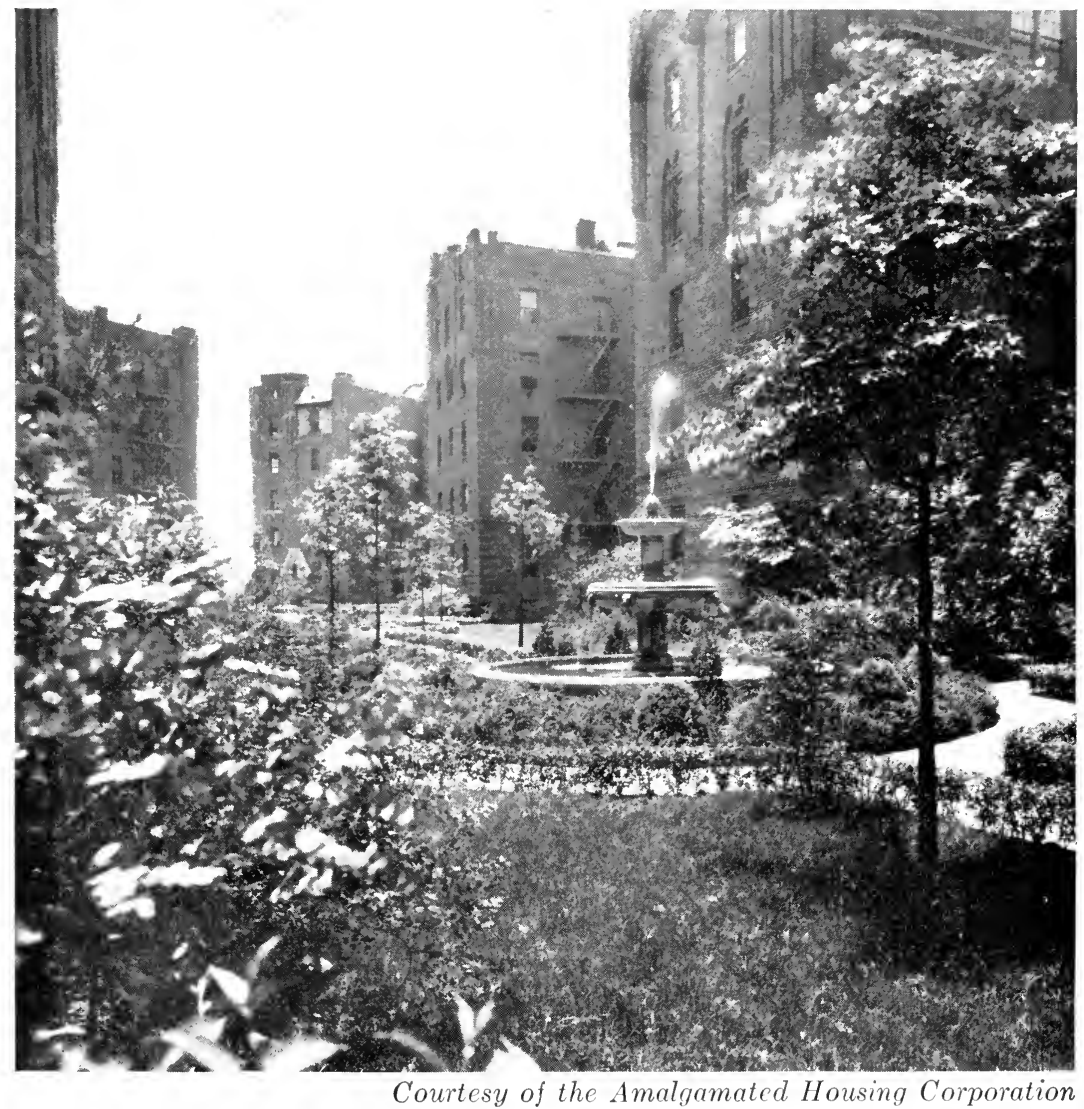

Amalgamated Housing Corporation, New York. Cooperative garden apartments for clothing workers made possible by tax exemption under the New York State Housing Law. 


\section{Recent Trends in American Housing}

by

Edith Elmer Wood, Ph.D.

Author of "The Housing of the Unskilled

Wage Earner", “Housing Progress in

Western Europe", etc.

Illustrated

率?

New York

The Macmillan Company

1931 
PRINTED IN THE UNITED STATES OF AMERICA

Copyright, 1931,

BY THE MACMILLAN COMPANY.

All rights reserved - no part of this book may be reproduced in any form without permission in writing from the publisher.

Set up and printed. Published October, 1931.

NORWOOD PRESS LINOTYPE, INC. NORWOOD, MASS., U. S. A. 


\section{ACKNOWLEDGMENT}

The writer wishes to record her sincere thanks and deep obligation to all the men and women in public and private life who have aided in the preparation of this book by supplying her with needed information, frequently unpublished, or by reading portions of the manuscript which dealt with events coming under their special cognizance.

For conclusions drawn and judgments expressed, the writer alone is responsible. 



\section{CONTENTS}

PAGE

INTRODUCTION

1. The problem . . . . . . . . 1

2. Health, morals, citizenship, happiness, as affected by housing . . . . . . . . 4

3. Retrospect. Summary of the housing situation in $1917 \quad 8$

4. Remedies for housing evils in the United States prior to 1917 . . . . . . . 10

5. Remedies for housing evils in European and other foreign countries before and since the War . . .

6. Sources of information on recent American urban housing

7. Sources of information on recent American rural housing

8. Home ownership in the United States . . . . $\quad$. 35

9. Minimum standard of housing . $\quad . \quad$. $\quad . \quad$. $\quad 39$

10. What is wrong with supply and demand? . . . 43

11. Family income. . . . . . . . 47

12. The place of housing in family budgets . . . 53

13. Four items in the cost of a home . . . . . 59

\section{CHAPTER}

I. WAR Housing . . . . . . . . 66

II. The Housing Shortage . . . . . $\quad$. 83

III. Rent Restriction . . . . . . . . . $\quad$. 95

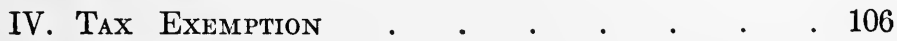

V. Tenement House and Housing Codes (DwellING LAws) . . . . . . . . 114

VI. RaPid Growth of Zoning . . . . . . 122

VII. City and Regional Planning . . . . 135

VIII. The Land Question . . . . . . . 149

IX. Satellite Garden Cities and Other New Towns 156

X. The Advent of Coöperative Housing . • . 171 
CHAPTER

XI. Housing Loans at Low Interest . . . . 185

XII. Eliminating Commercial Profit . . . . 206

XIII. Housing by Public Authorities . . . . 237

XIV. The New York State Board of Housing . . 259

XV. Slum Clearance . . . . . . . . . 274

Conclusion . $. \quad . \quad . \quad . \quad . \quad . \quad . \quad . \quad . \quad 283$

The economic cost of obsolete housing in preventable deaths, illness and crime versus the cost of clearance and replacement

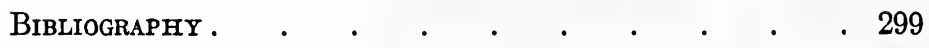

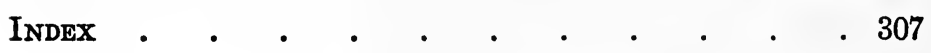




\section{ILLUSTRATIONS}

Coöperative Garden Apartments for Clothing Workers Built by the Amalgamated Housing Corporation, New YoRK Frontispiece FaCING PAGE

Why London Has a Lower Death Rate Than New York 16 Samples of Several Million American Homes

Government Housing for Shipbuilders (Emergency Fleet Corporation), Yorkship Village, Camden, New JERSEY

Government Housing for Munition Workers (United States Housing Corporation), Bridgeport, Conn.

Mariemont Garden Village, Cincinnati, Ohio

The First Radburn Super-blocks

Radburn, New Jersey

Amalgamated Housing Corporation, Bronx, New York 182 Paul Laurence Dunbar Apartments, Harlem, New York 226

Michigan Boulevard Garden Apartments, Chicago

Homes of California Veterans Acquired Under the Veterans' Farm and Home Purchase Act 
1 


\section{RECENT TRENDS IN AMERICAN HOUSING}





\section{INTRODUCTION}

\section{The Problem.}

The crux of the housing problem is economic. Under the ordinary laws of supply and demand, it is insoluble. In our modern industrial civilization, the distribution of income is such that a substantial portion of the population cannot pay a commercial rent, much less a commercial purchase price, for a home fulfilling the minimum health and decency requirements.

This is not a local or transitory phenomenon. It is universal and permanent,- - to the extent, at least, that our economic system is universal and permanent. The sooner we in the United States recognize these facts, as most thinking people in the rest of the civilized world have already done, the sooner we shall find a remedy. For of course there is one, if we choose to pay the price for it. No situation which is producing disease and crime faster than our remedial agencies can cure them is a necessity. As a matter of fact, other nations have found remedies and are putting them into effect. It cannot be done in a day. It cannot be done without sacrifice. But the progress in some countries has been remarkable. We may not like their remedies. But in that case, it would seem to be up to us to devise better ones.

No such simple remedy as raising wages will solve the problem. If the group involved were a small one, 
it might answer. But a general increase of wages for unskilled and semiskilled labor would add to the general cost of production and therefore to the cost of living, which would force up salaries and the wages of skilled labor. The cost of a home would increase in the same proportion, and we should be just where we were before, on a higher price level. It is not the absolute figures that are important, but the ratio between family income and the cost of a home.

It is easier in practice to lessen the cost of housing than it is to change the distribution of income in favor of the lower groups. It disturbs the existing order of things much less. Hence it is the course followed by such conservatively progressive nations as Great Britain, France, Germany, Belgium and Holland.

Changes in American methods of production since the World War have, it is true, injected some new and perhaps hopeful factors into the situation. Through the introduction of better machinery, more efficient management, better coöperation between capital and labor, we are told that the per capita productivity of American labor increased 53.5\% between 1919 and 1927. ${ }^{1}$ Productivity in 1919, however, was considerably below the pre-war level, so that the net gain is nearer $40 \%$. Due, partly at least, to the wide acceptance among employers of the economic theory that the increased products of industry can find a market only if the workers themselves are prosperous enough to be purchasers, the workers have shared in the added wealth that they have created to a substantial extent. The cost of living in the United States is about $70 \%$ higher than it was in 1913 , but wages average somewhat more than double (103\% increase in 1927 over 1913). The difference

${ }^{1}$ Report of the Committee on Recent Economic Changes in the United States, p. 104. 
means an increase of purchasing power amounting to roughly $18 \%$ in the case of wage earners and $9 \%$ for salaried persons. ${ }^{2}$

Such an increase means, of course, an enlargement of the group who are able to afford acceptable housing. It is certain, however, that nothing like all of the potential improvement has been realized. With cunningly worded advertising and high pressure salesmanship urging the worker to spend his new-found surplus on this, that and the other,--a radio, a vacuum cleaner, a fur coat, a diamond ring, over-stuffed furniture, a car, a piano,--all on the installment plan with seductively small first payments, it is only where both husband and wife are unusually clear-sighted and strong-willed that they can resist all these importunities and concentrate on what most of them need most, a better home. The number who do so will probably increase, as the near-wise have an opportunity to see what the wholly wise have been able to accomplish. But if such a tendency goes far, what will become of the stimulation to production by the expansion of the market for things in general? Concentrating on housing would stimulate only the production of building materials,-bricks, tiles, and boards, plumbing, lighting and heating fixtures. What would become of the rest of industry and the increased wages which each manufacturer has been willing to give in order to boost his own sales? In other words, won't this excellent increase in labor's share of the national income, not only stop growing, but start decreasing, if wage earners

${ }^{2}$ Report of the Committee on Recent Economic Changes in the United States, Chapter XII. According to W. I. King in "The National Income and Its Purchasing Power" (1930), the increase in purchasing power for wage earners by 1927 was $18.7 \%$ and for salaried persons $14.5 \%$. Since the spring of 1931, wages have fallen slightly and the cost of living substantially. 
should stop scattering their surplus among non-essentials and devote themselves to securing decent homes? ${ }^{3}$

\section{Health, Morals, Citizenship, Happiness, as Affected by Housing.}

Bad housing conditions which are injurious to health include lack of light (especially sunlight), lack of ventilation, dampness (as in underground dwellings), overcrowding, impure or inadequate water supply, lack of bathing facilities, insanitary or insufficient toilets, lack of sewer connection, uncleanliness, dilapidation, lack of screens against flies and mosquitoes, inadequate disposal of garbage.

The number of interior rooms in old houses, without windows to the outer air, is incredible to those who have not studied the subject. New York had over 350,000 such rooms in 1901. ${ }^{4}$ She has them still, except in so far as the buildings containing them have been torn down. Certainly those that remain number 200,000, perhaps 250,000. Boston has them, Philadelphia, Chicago, San Francisco,- - every big city. But so have many of the small ones, and they are not unknown in the open country. And then there are millions of rooms, only a little better, whose windows look out on dark, narrow courts and passage ways, sometimes mere cracks between two walls.

Darkness develops rickets in children and helps the spread of tuberculosis from every open lesion case.

${ }^{3}$ Economic discussions in this work, except as otherwise indicated, are based on conditions of normal prosperity, not on those obtaining during the present business depression.

${ }^{4}$ First report of the Tenement House Department, City of New York, 1902-3, p. 85. The second and subsequent reports of the California Commission on Immigration and Housing show the extent of the evil on the Pacific coast. Reports of the Michigan Housing Commission in 1916 and of the Housing Commission of Des Moines in 1917 show it in the Middle West. These are merely samples. 
Children cannot thrive where flowers have not sunlight enough to bloom. Almost all tenement babies have rickets to a greater or less degree. It is only within the last few years that the extent of the damage has been understood. The tubercle bacillus, expelled from the human body in sputum, is destroyed by the direct rays of the sun out of doors in fifteen minutes or so. It lives for a couple of hours in even a brightly sun-lit room, and perhaps for a couple of days in a room with northern exposure. In a dimly lighted court room, it survives for weeks, and in a completely dark room for months. It is easy to calculate how much this prolongation of bacillus life increases the chance of infecting the family of a patient in the advanced stages of the disease, especially the young children playing on the floor. Dark rooms, moreover, are not kept as clean as light rooms because the dirt does not show. ${ }^{5}$

Some of the largest cities, notably New York and Boston, have $100 \%$ city water and sewer connections for poor as well as rich. But only a few years ago, St. Louis had 40,000 privy vaults, Philadelphia 60,000 and Baltimore 90,000 . Since then St. Louis has achieved a reduction and the other two an almost complete elimination of the evil. Baltimore accomplished it in one great engineering feat after the fire, Philadelphia has done it piecemeal, with a yearly fight for a small appropriation. Both cities have reaped their reward in a much reduced death rate. Most American communities, however, have sections, large or small, inhabited predominantly by Negroes or the foreign-born, where neither city water nor city sewers penetrate. Filthy back-yard privies with overflowing vaults serve from two to a dozen fam-

${ }^{5}$ For a recent résumé of scientific knowledge on this subject, consult the section on Sunlight and Daylight for Urban Areas in the volume on Neighborhood and Community Planning, Regional Plan of New York. 
ilies. Water is carried by hand into the house from well or hydrant. Cleanliness of person or of home is rendered so difficult for such families that those who achieve it-and some do-deserve a distinguished service medal. Overcrowding spreads through the family each germ disease that overtakes any member, whether it be a cold in the head or infantile paralysis. The connection between overcrowding and epidemics is too well known to dwell upon. Overcrowding is also a serious nerve strain, especially when combined with the noise of city tenements. Mental and nervous break-downs of the wife and mother are especially frequent. The effect on infants and young children has never been seriously studied. ${ }^{6}$

Many stairs to climb mean increased cardiac cases. Dampness results in rheumatism. Typhoid comes from polluted milk or water or is carried by flies, who also carry the germ responsible for the enteritis of young children. Mosquitoes bear malaria. Hook-worm is prevalent where toilet facilities are absent.

Bad housing conditions which menace morals directly are overcrowding and lack of privacy in sleeping, bathing and toilet arrangements, especially where poverty has forced the irresponsible lodger or boarder into the family circle. Nor is the still darker menace of incest to be overlooked, either in city or country, where both sexes and all ages are herded together without possibility of day or night separation. Dark halls in city tenements offer an added danger to the morals of the young.

Indirectly, the ugliness and discomfort, as well as the crowding, supply a strong inducement for father, sons and daughters, to spend as few as possible of their lei-

6 This subject is treated at more length in the Conclusion, in connection with the nervous effects of noise. 
sure hours at home. Street, dance-hall, pool-room, speak-easy are waiting for them. Intemperance, loss of employment, desertion, disruption of the family, may result from the father's wanderings. Juvenile delinquency, vice and crime are too often the fate of the children.

Shabbiness and dilapidation produce mental depression and the frame of mind to which the label inferiority complex is commonly attached. Extreme slum conditions, on the other hand, foster violent bomb-throwing radicalism and an understandable spirit of hatred toward the society which tolerates them. No better way of helping Soviet propaganda could be devised than the conservation of slums.

As for happiness, aside from its intimate connection with health, morals and reasonable comfort, who has not felt the depressive influence of a cramped, badly lighted, shabby room and the exhilarating effect of space, good repair and a flood of sunlight? Normal family life can not exist apart from a normal home.

If the list of bad housing conditions be analyzed, it will be noted that some of them are structural-inherent in the house or lay-out,- -while others depend upon occupancy. These distinctions will help us to assign responsibility. As an English writer put it recently (Major Harry Barnes in a paper read before the Town Planning Institute), some people see nothing in slums but bad buildings while others see nothing but bad tenants, and the controversy as to whether the bad tenant is the cause of the bad building or the bad building is the cause of the bad tenant is as hard to settle as the relative priority of the hen and the egg. Obviously, however, such structural matters as windowless rooms, houses which cover too much of their lot, apartments partly underground, lack of water, lack of plumbing, 
lack of sewer connection, are not conditions created by the tenant. On the other hand, he is the creator of overcrowding (though he may not be able to help it) and he is responsible for uncleanliness within his apartment and sometimes outside of it. He and the landlord are in a perpetual state of trying to pass the buck as to responsibility for dilapidation and lack of repairs. Nor is it an easy matter for the outside observer to apportion the blame. Certainly, bad houses make careless tenants, and careless tenants make bad houses worse, and the vicious circle goes on forever. But justice requires us to remember that structural faults are quite outside the tenant's sphere of influence. He did not create them and he cannot cure them. Sometimes they are also beyond the landlord's power to remedy. As a rule, he did not create them, but acquired them long afterward. In such cases, the community is clearly responsible for the low standards it enforced at the time the house was built or converted to its present use. It is in this community responsibility that resides the $a$ priori justification for municipal slum clearance.

\section{Retrospect. Summary of the Situation in $191 \%$.}

For the history of housing in the United States, both as to conditions and attempted remedies, prior to the entrance of this country into the World War, reference is made to "The Housing of the Unskilled Wage Earner" (Macmillan, 1919), to which the present work is a sequel.

For three quarters of a century, a mass of material in the form of local housing surveys had been accumulating. Jacob Riis and Mrs. Albion Fellows Bacon did much to popularize it. Lawrence Veiller interpreted it and prescribed remedies.

The situation may be summed up in the briefest form 
by saying that, in 1917, one third of American families were living in good homes, one third in fair homes, more or less lacking in conveniences, but not unwholesome, while the last third occupied the oldest and worst castoff houses which no one else wanted. The housing of this last third was definitely sub-normal by any decent standard, and was having a deleterious influence on health, morals, and family life. The housing shortage after the war made this situation appreciably worse, enlarging the boundaries of the group which suffered. The subsequent period of intensive building brought it back to so-called normal. We are now approximately where we were fourteen years ago. Certain trends are, however, discernible, which it is the purpose of the following pages to discuss.

The estimate that a third of our people are badly housed was arrived at by careful computation of the amount of bad housing revealed by the numerous housing surveys that had been made in large cities, middlesize and small towns, on the assumption, apparently justified, that they revealed fairly typical urban conditions. At that time, little had been contributed toward the study of rural housing, but the inadequacy of much of it was a matter of common knowledge. The estimate from surveys was checked by considering the racial make-up of the population. Negro families and foreign-born families are so notoriously ill housed that they would fall, with few exceptions, in the sub-normal group. These two elements accounted for about 25\% of the population. Native whites, rural and urban, who are badly housed, are certainly sufficiently numerous to account for the remaining 8 or $10 \%$. Striking confirmation of these general estimates by a consideration of income distribution and the cost of building will be found in Section 11. 


\section{Remedies for Housing Evils in the United States prior to $191 \%$.}

Efforts to meet the housing situation in the United States were of the two main types described in "The Housing of the Unskilled Wage Earner" as restrictive and constructive. Of the former type, was the unevenly distributed system of regulatory laws and ordinances which set up minimum standards of light, air, sanitation and safety, by an exercise of the police power in the interest of health, morals and general welfare. Under the second heading must be classed employers' housing and the housing erected by limited divided companies, in so far as they produced better housing at cheaper cost than private business enterprise. The total amount of housing so produced was neglible in comparison with the great volume provided by commercial builders.

The New York Tenement House Law has been the American prototype of restrictive legislation. A tenement house is legally defined as one where three or more families live independently of each other, doing their cooking on the premises. It includes all grades of flats and apartments, but not hotels, clubs, or institutions. The first New York Tenement House Law was enacted in 1867. It was amended in the seventies, eighties and nineties and largely rewritten in 1901, when the Tenement House Department was established to administer it. A number of cities and a few states, as New Jersey and Connecticut, passed tenement house laws during the next few years, which were based on that of New York.

Later came the so-called housing laws, the earliest being the Columbus, Ohio, ordinance of 1911. These were wider in their application, as they covered one and 
two-family houses, hotels, and all other types of dwelling. In varying degree, they were all based on the Model Housing Law drafted by Lawrence Veiller, who had been the driving force behind the 1901 revision of the New York Tenement House Law and the creation of the Tenement House Department. Since the founding of the National Housing Association in 1910, Mr. Veiller has been its executive director. A number of cities and some states passed this type of legislation between 1913 and 1919. The subject is further discussed in Chapter V.

Regulatory legislation is an absolutely essential part of any all-around housing program, since without it all sorts of atrocities would be perpetrated-are being perpetrated. But it is only a beginning. It may forbid the bad house, but it does not provide the good one.

Limited dividend housing companies sought to supply this complementary need,--good houses at lower cost-by cutting out speculative profit. Most of the pre-war companies limited themselves to a $5 \%$ return on their invested capital. A few contented themselves with $4 \%$. They were predominantly philanthropic or civic in their underlying motive. Employers were influenced in addition-sometimes exclusively-by the need of maintaining their labor force. Toward the end of the period, a number of limited dividend companies were organized under Chamber of Commerce auspices. Certain optimists hailed this as the American solution of the housing problem. As will be seen in Chapter XII, their hopes were not destined to be fulfilled.

Early examples of limited dividend housing in the United States include the Boston Coöperative Building Company (1871), the Alfred T. White model tenements in Brooklyn (1878-90), the Sanitary Improvement Company (1897) and the Sanitary Housing 
Company (1904) of Washington, the City and Suburban Homes Company (1896) of New York, and a very few others. The best results, with due regard to rental and standard, were probably attained by Mr. Schmidlapp's Model Homes Company in Cincinnati (1911), which, of course, profited by the experience of its predecessors. The discouraging feature of the movement was that it showed no appreciable tendency to expand.

It should be clearly understood that restrictive housing legislation involves an expansion of the functions of government, limiting the right of the individual to do as he likes with his property at the point where the community believes the health, morals or safety of others are liable to be endangered. Such regulations are always resented and fought by owners of insanitary and dilapidated old houses and by those builders and real estate developers who want to overcrowd the land with shoddy buildings in the future.

On the other hand, limited dividend housing is in competition with that supplied by ordinary business enterprise and is just as truly an interference with the laws of supply and demand as municipal housing, for instance. One suspects that the comparatively mild opposition it has encountered is largely due to its feebleness as a rival.

5. Remedies for Housing Evils in European and Other Foreign Countries before and since the War. ${ }^{7}$

European countries (and to Europe, for our purposes, we must add New Zealand, Australia, and to a lesser degree, South America, South Africa, Canada and

${ }^{7}$ For further information, see the author's "Housing Progress in Western Europe," Chapter V in "The Housing of the Unskilled Wage Earner," and Louis H. Pink's more recent "The New Day in Housing." Foreign references will be found in the bibliography. 
Japan) have gradually worked out a philosophy and practice of housing based on the proposition that, both for their own sake and that of the nation, all children must be brought up in healthful surroundings. ${ }^{8}$ The problem is to bring this about with the minimum dislocation of existing social and economic machinery. All except the extreme radicals (exemplified by Soviet Russia and the Socialist government of Vienna) are agreed that so far as private business initiative and the laws of supply and demand are producing acceptable homes, they should continue to do so. Where supply and demand fail, they have come to agree, the community should step in.

For the accomplishment of these aims, European countries have developed three major forms of housing activity which are all but unknown in the United States: (1) slum clearance to get rid of irredeemably bad old houses, carried on by public authorities as a health measure, nearly always involving considerable expense to the tax payers; (2) housing loans at low interest rates, tending to be that of government bonds, providing a large amount of accessible capital and eliminating the always costly second mortgage; (3) housing by public authorities, usually municipal, for those not otherwise provided for.

Different schools of thought favor widely divergent methods. When the conservatives are in power, encouragement is given to home ownership and private enterprise. Money is lent at low interest rates and for a long period to the purchaser of a home. We have the Belgian General Savings Bank lending $80 \%$ of the

${ }^{8}$ Our mode of reasoning has been similar in regard to universal free education, $-a$ much more radical provision, since it lays an enormous burden on the tax-payers, whereas housing by public authorities is normally self-supporting. Yet health and decency are more fundamental needs than schooling. 
money needed for purchasing a home, for 25 years, at a low interest rate. In France, the Ribot law and agricultural credits function in the same way. In Sweden, under the "Own Home" law, the government in effect offers second mortgage money at 5\% interest for the difference between the first mortgage and $90 \%$ of the value of the house and land.

When the radical groups are in office, home ownership is soft-pedaled, and efforts are concentrated on government loans to coöperative housing societies, or on municipal housing rented to workers, or both. The socialists are convinced that home-ownership makes workingmen conservative and attached to the existing order.

Neither policy necessarily, or indeed normally, involves subsidy. Before the war, housing loans, whether to societies or individuals, and also municipal housing, were carried on at cost without throwing any burden on the tax payers. It was like a municipal water supply, which is expected to pay its own way and retire its bonds, though not to make a profit. Slum clearance, on the other hand, costs money. It is undertaken as a public health measure, to rid the whole community of a menace, not simply to provide better homes for the small group immediately concerned. Like other corrections of past errors, it tends to be expensive. Compared, however, with such undertakings as the elimination of grade crossings, it costs much less per life saved and accomplishes the saving of vastly more lives.

Subsidy in connection with housing loans or with municipal housing is a post-war phenomenon. It was adopted as a temporary emergency measure and a lesser evil than waiting for financial stabilization. Nearly all subsidy legislation was enacted in 1919 . In some countries, it has already come to an end. In others it has 
been greatly reduced. In a few years, the housing of all classes, except the small dependent one which exists everywhere, will once more be on a self-supporting basis. But the housing of the lowest economic third of the population will have been permanently removed from the field of private business enterprise, and the housing of the middle third partially so.

Compressing pre-war British housing history into a few words, we may call 1850-1870 the period of discussion and awakening, and 1870-1890 the period of regulatory legislation, slum clearance, and housing by philanthropic foundations and limited dividend companies,-approximately the state of public opinion which we are now going through, except that we have not gone beyond the talk stage in slum clearance. During the important twenty years, 1890-1910, the struggle was between private initiative as represented by the Public Utility Societies (limited dividend) and housing by local authorities, urban, rural, or county. It was now conceded by both sides that private capital was unequal to the task, and that government loans were necessary, whether to the private societies or the public authorities. Between 1910 and 1914 housing by local authorities made vast strides in Great Britain. Progress could not have been so rapid, however, nor could so high a standard have been attained without the object lessons created wholly by private initiative-Port Sunlight, Bournville and Earswick, built by enlightened employers, and Letchworth, the first Garden City, built in accordance with the ideas of Ebenezer Howard. It is thanks to these demonstrations that the housing of the English ${ }^{\circ}$ working classes today is largely in cottages set among gardens and not in tenement houses.

' Not true in Scotland, where the tall tenement house still prevails. 
Post-war housing in Great Britain has expanded into a movement which can only be described as a peaceful social revolution. Parliament was pledged to provide good housing for the returning soldiers. Hence the Lloyd George or Addison Housing Act of 1919, with its loosely drawn subsidy provisions. Half a million homes were to be built in three years. Only half the program was actually carried out owing to the great expense. But 250,000 dwellings, 174,000 of which were built by local authorities in England and Wales, represented a fairly large achievement, especially as a very high standard was set in hygiene, comfort, and beauty. Nearly all were five and six room cottages of brick or concrete (counting the scullery as a room), with electric lights, gas ranges, hard wood floors and all the other modern improvements, except central heat. They are built not more than 12 to the acre in cities or 8 to the acre in rural communities and rent for from $\$ 2$ to $\$ 5$ per week.

Building under the 1919 Act having come to an end, public opinion forced a reluctant Conservative government to enact a new housing subsidy law (Chamberlain Act of 1923) to take its place. The amount of subsidy for a house built by local authorities was limited to $£ 6$ a year for 20 years, and to make this possible without increased rents, the housing standard of 1919 was lowered in several particulars. The most characteristic feature of the Chamberlain Act, however, was one designed to encourage the private builder, who was to receive a flat subsidy for putting up a small house of prescribed standard, which he was to sell at a prescribed price. This has produced 405,141 little homes which have been sold to lower middle class families, resulting in a marked increase in home ownership. Only 78,000 working class houses were built under this act by local 

authorities, who were soon to have more advantageous terms offered them.

In 1924 the first Labor Ministry came in and did not repeal the 1923 Act, but added to it the 1924 (Wheatley) Act. This offered a $£ 9$ subsidy for 40 years to local authorities building according to the high standards of the 1919 law. Rural authorities received somewhat more. Over 366,000 houses have so far been built under these provisions, except that the amount of subsidy was cut to $£ 7$ per year in 1927 .

An extremely important contribution of this ministry was the fifteen-year program for the building of two and a half million homes by 1940. An agreement was brought about between building trade workers, employers and material men not to increase the cost of building during the fifteen years.

The Conservatives returned to office within a year, but did not interfere with the 1924 Act or the fifteen-year program.

Altogether, in the ten-year period completed in 1930 , over 1,000,000 "assisted" houses were built in England and Wales and over 100,000 in Scotland, accommodating nearly one eighth of the population.

The Housing Act of 1930, prepared by the second Labor Ministry, seeks to speed up rural housing and slum clearance. Financial assistance by the national government takes the form of a per capita payment for 40 years for each person removed from insanitary quarters for whom new quarters have been provided, the amount being 45 shillings a year in urban districts and 50 in rural districts. It is estimated that 100,000 persons a year will be displaced and re-housed.

The amount of subsidy paid by the British people for housing has been greatly exaggerated by careless writ- 
ers in the United States. According to official figures given in the October 1929 issue of Garden Cities and Town Planning, total housing subsidies paid by the national government during the decade ending March 31, 1929, in England, Scotland, and Wales, came to $£ 82,621,517$, of which over 73 million were for the admittedly extravagant 1919 houses. The annual charges on the exchequer at the present time are between 9 and 10 million pounds. The annual subsidy for a 1919 house seems to be about four times as high as for a Wheatley house, and it will go on for a longer time. Evidently, there are subsidies and subsidies.

Germany was, along with England and Belgium, a pioneer in housing betterment during the quarter century preceding the War. In addition to restrictive laws, she developed a system of government loans to encourage coöperative housing societies and a system of direct municipal building. Interrupted by the War, the program was later resumed with great energy. Between 1919 and 1928, housing was created by these means for over 1,100,000 families. An important aid in financing has been the rent tax (Hauszinsteur), imposed on owners of pre-war houses who had profited by the three fourths cut in their mortgage obligations brought about by fluctuations in the currency. The great bulk of this building has taken the form of apartments of two to four rooms, with water-closet, but not always a bath. Though the standard is thus seen to be definitely lower than that of England, and there must still be considerable crowding in sleeping accommodation, the new apartments represent an increase in the number of rooms per working-class family, their architecture is good, light and air ample, and landscaping attractive. A marked drop in the general death rate has 
accompanied the housing program. Germany now has, for the first time, a lower death rate than the United States.

If Great Britain and Germany have built more houses in absolute numbers, Holland has built most in relation to population, having re-housed one fifth of her population with public assistance since 1915, and mostly since 1920. This is a very remarkable achievement. The standard is not so high as in England, although the three-bedroom norm is accepted. But bathtubs are omitted from working-class houses, which are built closer together, with less garden and play space. In Amsterdam, many of them are two-family houses, and in Rotterdam, three and four story tenements are found. Subsidies, never so high as the British, have come to an end for new houses and are being gradually tapered off on the houses built at the period of maximum cost.

Nearly all other European countries have developed some form of housing loan at low interest rate and some form of municipal housing or a slightly disguised substitute for it. The amount of slum clearance done has been much less than the work carried out under either of the other heads.

6. Sources of Information on Recent American Urban Housing.

The post-war period has not been rich in housing surveys of the older type. So much information showing bad conditions had been gathered and so little had been done to remedy them that there was small incentive to go on. Why survey again?

The Housing Commission of the City of Des Moines published a 64-page illustrated report in 1917, showing dark interior rooms, fire traps, shacks and other evils. 
This was used in the successful campaign for the Iowa State Housing Law.

The Board of Health of Lexington, Ky., caused a housing survey of the city to be made by Madge Headley, an experienced investigator, between January and April 1924. Its 46 pages and illustrations show the familiar overcrowding and dilapidation in sections of the city without sewers or water.

Miss Headley, a little earlier, made a study of Negro housing in Chicago for the Women's City Club. This was followed in 1925 by an official report on "Living Conditions for Small Wage Earners in Chicago" by Elizabeth A. Hughes for the City Department of Social Welfare, of which Mary E. McDowell was the head. It dealt chiefly, though not exclusively, with the housing of Negroes and Mexicans. The University of Chicago (Abbott and Breckinridge) studies of Chicago housing conditions have been for some time past in process of being brought up to date, but are not yet available in print.

An important government publication appeared in 1920 - "Housing by Employers in the United States" (Bulletin 263 of the Bureau of Labor Statistics, by Leifur Magnusson, 283 pp. illus). ${ }^{10}$ It deals with 423

${ }^{10}$ See Chap. XII.

As is customary in government reports, the companies described are not identified either by name or locality. Housing standards run the gamut from atrocious to excellent. According to this report, companies in the cotton mill region generally insist that each room in the house shall provide an operative for the mill. This is a shockingly anti-social requirement, pushing to child-labor, the taking of boarders and lodgers, and obviously to overcrowding. The population of three southern cotton mill villages is given, one as housing 1500 persons in 878 rooms, another with 3431 persons in 2638 rooms, and the third with 1000 persons in 465 rooms. Some Pennsylvania coal companies still house their foreign-born employees in wooden barrack rows, without improvements, built at the time of the Civil War. Many western mining companies consider their obligations to Mexican workers liquidated by permitting them to build themselves shacks on company land. 
company towns owned by 213 companies, mostly mining or textile, in various parts of the country, who provided housing, good or bad, for over $160,000(34.4 \%)$ of their employees. Some of these communities were built as long ago as 1840, others as recently as the World War. "Generally speaking, company towns are unsewered and without a piped water system for a large majority of the buildings. . . . The typical company house is a single or detached frame house consisting generally of 4 rooms." Of the 47,580 dwellings for which data were available, $17.3 \%$ had modern improvements (bath, water-closet, running water and gas or electricity), while $39.2 \%$ had none, $22.3 \%$ had gas or electric light only, and $5.4 \%$ had running water only.

Perhaps our best sources of housing information during the past decade may be described as continuous surveys by either public or private bodies. Of the latter sort are the exceedingly useful annual studies of the Philadelphia Housing Association and those not quite so frequent of the Cincinnati Better Housing League, covering now one phase of the subject, now another, in various sections of the city, returning after a year or several years, to note the changes that have taken place.

In New York, a survey of eight scattered blocks selected as typical was made first in 1920 for the Housing Committee of Governor Smith's Reconstruction Commission, repeated in 1923 and 1925 for the Commission of Housing and Regional Planning, and in 1927 and 1928 for the State Board of Housing. It deals chiefly with congestion and rentals.

The New York Evening World, during the autumn of 1923, while the shortage was still acute, conducted an investigation of its own, sent its reporters to live in the slums, featured their sensational write-ups, and tried, without much success, to start a landslide for municipal 
housing, slum clearance, or anything that would improve matters.

In 1928, the United Neighborhood Houses made a useful little study of the housing of 1014 families frequenting settlements in various parts of the city, which has not yet been published.

Portland, Ore., Los Angeles, Kansas City, St. Paul, Detroit, Indianapolis, Boston, and other cities have conducted housing inquiries.

The California Commission of Immigration and Housing from time to time goes over the ground of its earlier housing surveys. One such was published in 1923 under the title of "A Report on the Housing Shortage." It dealt with cities which included $45 \%$ of the population of the state.

Each of the Infant Mortality studies of the Children's Bureau in Washington contains a chapter on housing conditions. Pre-war numbers dealt with Johnstown, Pa. (1915), Montclair, N. J., and Manchester, N. H. (1917). The Waterbury, Conn., study appeared in 1918, Brockton, Mass., and Saginaw, Mich., in 1919, New Bedford, Mass., and Akron, Ohio, in 1920, Gary, Ind., and Baltimore in 1923.

The last mentioned is particularly valuable from a scientific point of view, because it deals with a sufficient number of cases to classify deaths by race of mother and income of father as well as by room density in the family home. It is therefore possible to eliminate the influence of race and poverty on the infant death-rate and to show to what extent it varies with increasing congestion. The effect of bathtub, sewer connection and a toilet for the family's exclusive use is also, though less satisfactorily, recorded (pp. 106-114).

The congestion correlation is worked out for eight cities, including Baltimore, in the final volume of the 


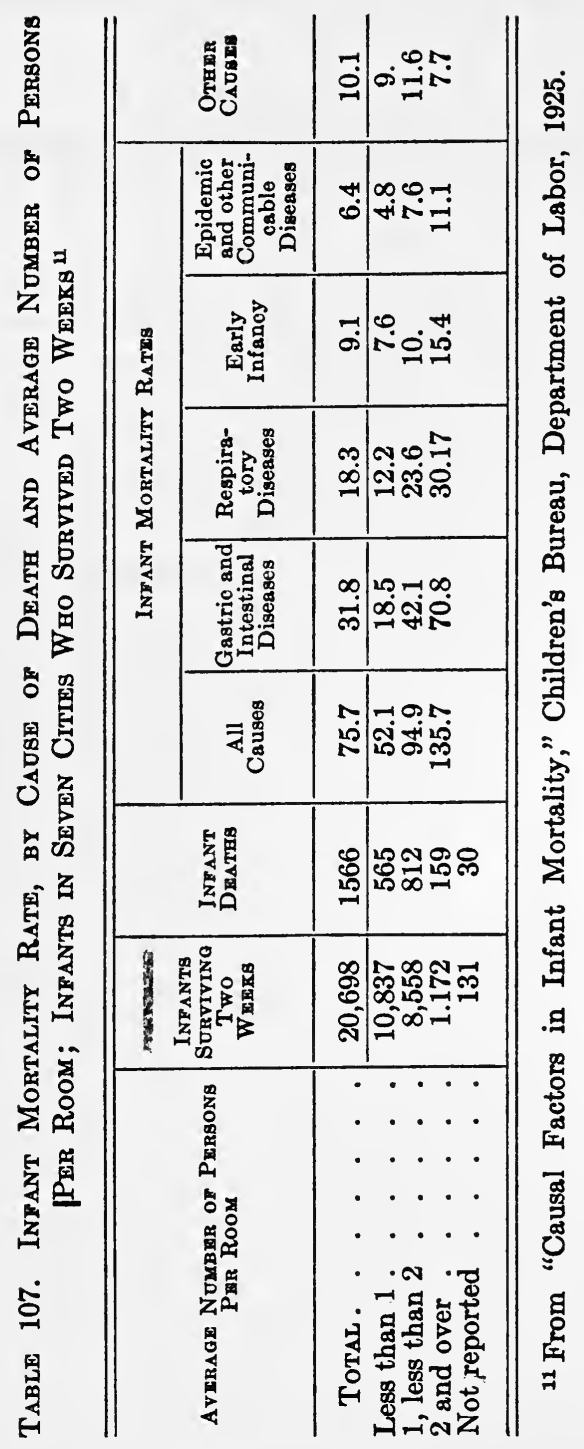


series, "Causal Factors in Infant Mortality" (Bureau Publication 142, 1925). In the section on Housing Congestion (pp. 125-130) the matter is summarized as follows:

"Housing congestion was found to have exerted an influence upon infant death rates, the mortality among infants in homes in which the number of persons averaged two or more per room being two and a half times as high as that among infants in whose homes the number of persons was less than the number of rooms. When allowances were made for the correlation between housing congestion on the one hand and earnings of fathers and nationalities of mothers on the other, this apparent excess mortality among babies in the most congested dwellings was reduced to about twice that among the babies in the least congested homes."

It is also pointed out that if correction were made for the factor of breast feeding, which is most prevalent in the most crowded homes and tends to reduce infant mortality there, the evil effect of congestion would be seen to be even greater than the tables show.

While elaborate city surveys such as those of Pittsburgh and Springfield, Ill., characteristic of the previous decade, have not been made, we find valuable data on housing in such a sociological study as "Middletown," by Robert S. and Helen Merrell Lynd (1929). The original Middletown, generally understood to be Muncie, Indiana, was selected as a typical medium-size Middle Western town. Chapter IX, The Homes in which Middletown Lives, indicates that 38,000 people live in 9,200 homes, that $86 \%$ of these homes are detached singlefamily houses, and that two thirds have sewer connections. Presumably, therefore, one third do not. This and other items are strictly confirmatory of the generalizations in Section 3. On the other hand, $99 \%$ of the homes have electric light, undoubtedly the most widespread of our modern improvements and the one having 
the least connection with health or morals. Rents run from $\$ 10$ to $\$ 25$ a month for $27 \%$ of the homes and from $\$ 25$ to $\$ 40$ for $44 \%$.

In 1927 the Literary Digest published a report (188 pp.) on "Zanesville and Thirty-Six Other American Communities" prepared for them by a research agency, R. A. Eastman, Inc. For the information of advertisers, the report seeks to analyze "the average American home [family?]-how it lives, how it works and plays, what it eats, where it spends its money. ... F For the answer to these questions is part of the solution to their problem of marketing." Incidentally, it presents considerable socially useful information concerning Zanesville, Ohio, selected as an average American town. Here every home was visited, though interviews were obtained in only $68.4 \%$ of them, 4596 in all. From the 6636 homes visited in the 36 other cities, no standard-of-living deductions whatever can be made, as the report states (p. 24) "the less prosperous section of each community was given less attention than those containing the middle class of houses." 12

In Zanesville, $52.2 \%$ of families visited live in homes estimated as being worth from $\$ 1000$ to $\$ 4000$, and $31.5 \%$ in homes worth from $\$ 4500$ to $\$ 6000$. No bathrooms are found in $38.2 \%$ of homes, $59.6 \%$ have one and $2.2 \%$ have two or more. In $73.7 \%$ of homes there is electricity and in $96 \%$ gas. In $90.5 \%$ there is running water and, by inference, in $9.5 \%$ there is none. Nearly $70 \%$ of the families own their homes. Forty-eight per cent own one automobile and $2.8 \%$ own two or more. The fact that almost half the families own none is indicative of the over-optimism of automobile figures generally circulated. Only $2.3 \%$ of Zanesville families

12 The caution is not superfluous, as one of our most distinguished housing authorities has fallen into this error. 
employ full time servants, while $2.5 \%$ have part time help. The full time group corresponds rather closely in size to those having incomes of $\$ 5000$ and over.

The General Federation of Women's Clubs in 1925 and 1926 carried out an ambitious nation-wide survey of urban home equipment, which, with the best will in the world, it is hard to take very seriously. The Industrial Survey and Research Service of Washington prepared their schedule and checked and tabulated the returns, but the field work was done by unsupervised club members in nearly 1500 communities. They were told to get their information from city officials and public utility companies, or failing these, from real estate or electric supply dealers, taking estimates where exact figures were unknown. It is the writer's conviction, based on considerable experience, that exact figures would be obtainable in very few communities and that the tendency of the booster spirit to affect estimates through the desire to give the home town a good name would be overwhelming. ${ }^{13}$ The survey reports $82.2 \%$ of urban dwellings as having flush toilets and $68.3 \%$ as equipped with stationary bathtubs. Both figures are quite certainly too high. The results of the survey were not printed, but circulated rather widely in mimeograph.

Figures supplied by electrical companies indicating that 17 to 18 million American families light their homes by electricity are probably reliable. From trade sources also comes the statement that since $19221,100,000$ enamel bathtubs have been installed annually in the

${ }^{13}$ This tendency was strikingly exemplified in the returns from questionnaires sent to the branches of the American Association of University Women by the National Committee on Housing of which the writer was chairman. See "The Result of the Housing Questionnaires" in the January, 1926, issue of the Journal of the Amer. Assoc. of Univ. Women. 
United States. ${ }^{14}$ But there is no way of telling how many were replacements. Most new houses are equipped with them, and a number of owners of older houses, mostly of the middle income group, are having them put in for the first time, but how many, no one knows.

Virtually every civilized country in the world except the United States has national census figures to show what proportion of its population is living in crowded or over-crowded conditions. ${ }^{15}$ The number of persons in the family divided by the number of rooms which the family occupy gives the coefficient of room density. Any density over one is found to exert an unfavorable influence on health, increasing with the density. Anything over two is grossly bad (See previous reference to Children's Bureau study).

Some countries, as Norway and Holland, collect through their census much other housing information in addition to room density. Home ownership is the only subject connected with housing on which our American census has given us information, except the items about farm homes referred to in the next section, and increasingly meaningless figures on families and dwellings. ${ }^{16}$

${ }^{14}$ Quoted by Dr. Maurice Leven in the section on Housing of Chap. I, "Recent Economic Changes in the United States."

15 "The Statistics of Room Congestion," Edith Elmer Wood, Journal of the American Statistical Association, Sept. 1928.

16 "A dwelling, for census purposes, is a place in which one or more persons regularly sleep. It need not be a house in the usual sense of the word, but may be a hotel, boarding house, institution, or the like. A boat, a tent, a freight car, or a room in a factory, store, or office building, although occupied by only one person, is also counted as a dwelling, while, on the other hand, an entire apartment house, although containing many families, constitutes but one dwelling." 14th Census of the U. S. Population, 1920, Dwellings and Families, p. 3. Figures concerning number of dwellings, persons per dwelling, and families per dwelling, in this sense, are nearly useless and in many cases confusing. 
A strong effort was made by the American Association of University Women, aided by thirty-odd other organizations, to get the number of rooms per family on the population schedule of the 1930 census. The only result was a promise to make the inquiry experimentally in a couple of cities, and even this got crowded out at the last minute. The inclusion of such an obviously trade-inspired item as the possession of a radio instead of one so packed with social significance as the number of rooms per family, was particularly disheartening. ${ }^{17}$

One fortunate by-product of the agitation for this inquiry was its inclusion in the 1928 School Census of Detroit. Two questions, number of persons and number of rooms, were asked of every family whether they had children or not. The results were not tabulated in the most useful way, as they showed only the average room density in each of the 588 School Census districts, instead of the number of families living at specified room densities. Even so, it was important to find that in 53 districts the average density was more than one person per room and in 88 districts almost one per room, these two groups having a population of nearly 300,000 . The worst districts had average densities of 1.46, 1.57, 1.71 , and 2.66 per room (Home Index, Nov. 1928, p. 7). ${ }^{18}$ Dr. S. James Herman, executive director of the Michi-

${ }^{17}$ Further information will be found in "Methods of Compiling Housing Statistics," Studies and Reports, Series N (Statistics), No. 13, International Labor Office, Geneva, 1928.

${ }_{18}$ G. W. Clark in "The Housing of the Working Classes of Scotland," 1930, Chap. II, defines the Index Figure of Occupational Density of a Community as the number of persons per 100 rooms. "This figure gives a just approximation of the housing conditions in any community." He states that "in England any community whose index figure is over 105 is considered to be unsatisfactory." For England and Wales as a whole, the figure is 91 and for Scotland (notoriously overcrowded) 142. London's worst metropolitan borough has 154 and Scotland's worst 241. 


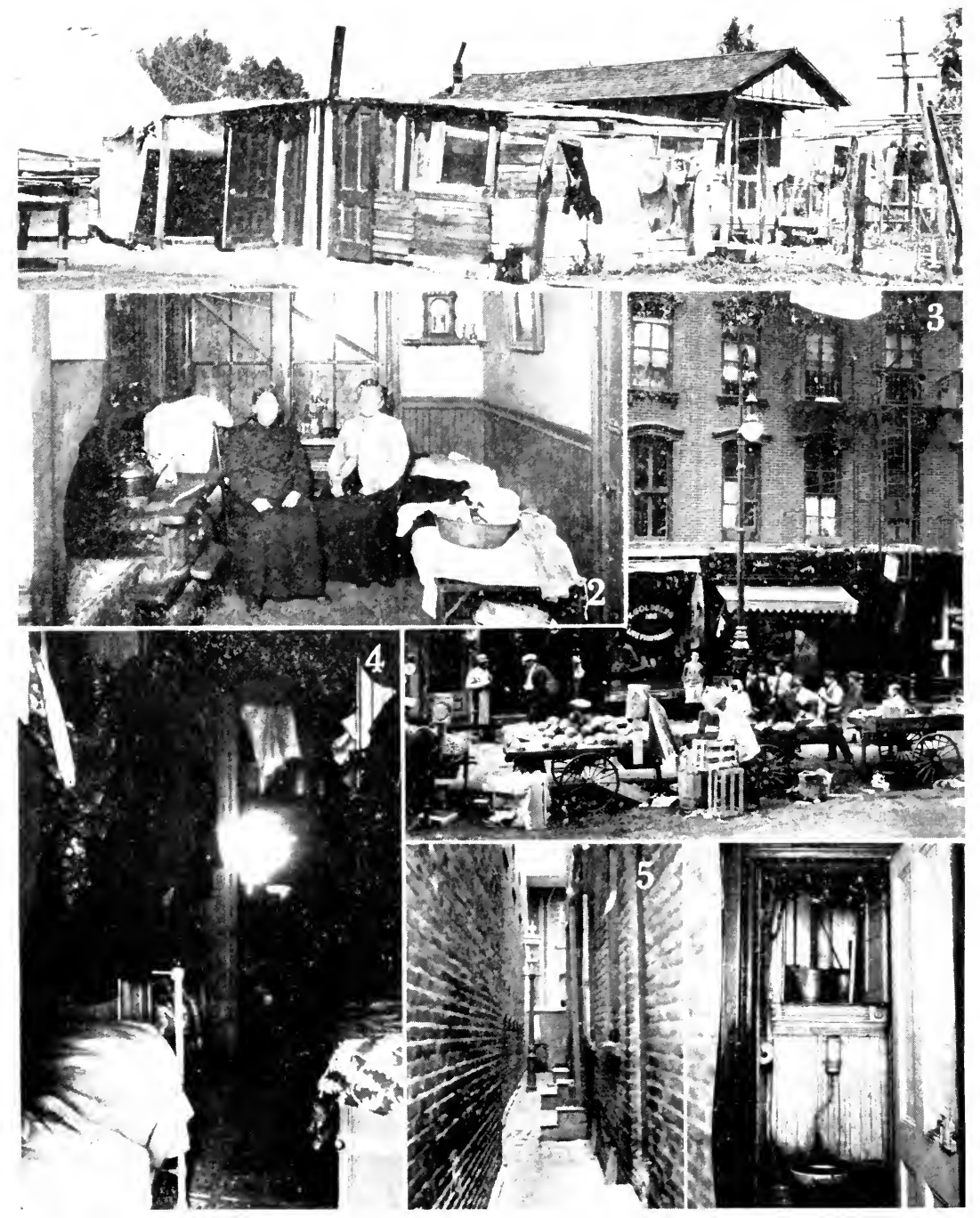

Samples of several million American homes. 1. Mexican laborer's shack. Fresno, California. (Courtesy of the California Commission of Immigration and Housing.) 2. A basement home with scanty daylight. (Courtesy of the Women's Municipal League of Boston.) 3. Old-law tenements in down-town New York. (Courtesy of the New York State Board of Housing.) 4. Three dark rooms in a row in a building erected before the window requirements of 1879 . (Courtesy of the New York Tenement House Department.) j. Alley houses facing on a blank wall. (Courtesy of the Philadelphia Housing Association.) 6. Hall toilet shared by two families in old-law tenement, New York. (Courtesy of the Lenox Hill Neighborhood Association.) 

gan Housing Association, has brought together some interesting maps and charts derived from this material, in City Health, the publication of the Detroit Health Department, for July and August 1929. The 588 census zones are here combined into groups of approximately equal population, arranged on an ascending scale of room density. Correlation of room density with infant mortality, with tuberculosis and pneumonia death rates and with juvenile delinquency appears to be high. It is greatly to be hoped that public spirited citizens of Detroit will provide the funds to tabulate these returns by number of rooms and number of persons per family, at least in the more densely populated districts.

\section{Sources of Information on Recent American Rural Housing.}

In the past, rural housing has been overshadowed by the more conspicuous evils of city housing, but its problems can not be ignored much longer.

No one knows how many one-room and two-room cabins there are among the Negroes and poor whites of the South, among the mountaineers of North Carolina, Tennessee and Kentucky, among the Mexican laborers of the Southwest, and sporadically elsewhere. Whatever the number, it is too many. Family life cannot develop normally under such pressure.

Contaminated water is more apt to be found in rural districts or small towns than in cities. The modern city usually has a fairly abundant supply of reasonably pure water. But many farmers are still careless about the location and depth of their wells, and wells linger on in villages and small towns which long since should have abandoned them.

Contaminated soil in the hook-worm belt is another 
$30 \quad$ Recent Trends in American Housing

danger to health, proceeding in a large degree from a lack of even the primitive yard privy. The Rockefeller Sanitary Commission organized a campaign against this condition in 1910, which it has gradually turned over to the county health authorities. In 1925, it was still giving aid to 220 counties in 26 states. Early surveys showed as high as $80 \%$ of infection in some counties, but a great improvement has been realized everywhere, in some places amounting to almost complete eradication. The thousands of sanitary privies installed by or under the auspices of the Commission form an essential part of the record.

A considerable part of the indictment against rural housing is based on the almost complete lack of modern conveniences. The 1920 Census, under Selected Farm Expenses, Chap. VIII, Vol. V, p. 514, gives nation-wide figures for certain rather curiously selected items. Thus, $10 \%$ of our farms had water piped into the house and $7 \%$ had gas or electric lights, while $30.7 \%$ had automobiles and $38.7 \%$ had telephones. Geographical differences are marked. The percentage of running water varied from 1.5 in East South Central states to 47.9 in New England, or from $1.1 \%$ in Mississippi to $62.9 \%$ in Vermont. Modern lighting was most common on the Pacific slope $(19.3 \%)$ and least so in the West South Central states $(1.9 \%)$. But the state which had most was Utah (43.4\%), while Louisiana, Mississippi and Arkansas all had 1.1\%.

There is an admirable Nebraska study dealing with 117,758 farms ("Nebraska Farm Homes," U. S. Dept. of Agriculture and Agricultural Experiment Station of the University of Nebraska, 1923). Nebraska is a progressive state with conditions far above the average for the nation. Thus we find $10 \%$ of these farm homes had indoor toilets and $17 \%$ had bathtubs. The fed- 


\section{Introduction}

eral census gave 16.6 and 9.7 as the Nebraska percentages of water piped into the house and electric light or gas.

Another valuable study, now out of print, is "The Farm Woman's Problem," Florence E. Ward, 1920 (U. S. Dept. of Agriculture). It is based on 10,044 questionnaires distributed by county Home Economics agents and filled out by farm women in 33 northern and western states. Women with the intelligence and patience to fill out these elaborate schedules must have been a selfselected group, so the returns must give a picture distinctly above the average for sections of the country where conditions tend to be most favorable. We find that $32 \%$ of them had running water against $10 \%$ for the country as a whole in the 1920 census, and $65 \%$ had water in the kitchen. (The difference between $32 \%$ and $65 \%$ is accounted for by pumps.) Twenty per cent had bathtubs and $15 \%$ indoor toilets (both higher than the high Nebraska percentages), 95\% had sewing machines, $96 \%$ had door and window screens. Yet their average number of hours of work per day was 11.3,13.1 in summer,-87\% never took a vacation, $96 \%$ did all their own washing, $92 \%$ their own sewing, $94 \%$ baked their own bread, and only $15 \%$ had power machinery to help them in any of their tasks, although electric power was used in farm work in $42 \%$ of cases. In this selected group, $42 \%$ had cars and $72 \%$ telephones. The women in this study had an average of eight rooms to care for, so that they suffered from too much rather than too little space. They averaged two stoves to keep going in winter beside the kitchen range. Where water was carried, women were the bearers in $61 \%$ of the families, the average distance being 39 feet.

It is easy to deduce from all this that the hard life of the farmer's wife may be an even greater force 
driving young people cityward than the hard life of the farmer. The compensating independence, so precious to the farmer, does not come into her case.

Of later date are a number of studies by sample carried on under the Department of Agriculture, where the number of cases is so small and the method of selecting them so problematical that it is impossible to give them much weight. The results are published in Bulletin 1466 of the Department of Agriculture, "The Farmer's Standard of Living," described as a SocioEconomic Study of 2886 White Farm Families of Selected Localities in Eleven States, by E. L. Kirkpatrick (November 1926). The eleven states are New Hampshire, Vermont, Massachusetts, Connecticut, Kentucky, South Carolina, Alabama, Mississippi, Kansas, Iowa and Ohio. It will be observed that the average number of families per state was 262. The four New England states together mustered only 317. Housing receives only incidental attention in this bulletin. The following summary, however (p. 22), is not without interest:

"Slightly more than a twentieth of all the homes reporting were completely modern: that is, fitted with central heating and central lighting systems, running water, kitchen sink and bathroom (equipped with stationary tub and bowl), indoor toilet and sewage disposal. About a fifth of the homes were partially modern; that is, fitted with a part of the improvements named. Almost three fourths of the homes have none of the modern improvements mentioned above."

The General Federation of Women's Clubs also sponsored a Farm Home Equipment Survey, ${ }^{19}$ which was conducted on a wholly different system from the Urban Survey. Returns were from individual farms. The questionnaires were largely distributed and col${ }^{10}$ Circulated in mimeograph form only, 1926. 


\section{Introduction}

lected by County Home Demonstration Agents or Farm Bureaus. In some states the Granges coöperated. Geographical distribution was irregular. New York is the only Middle Atlantic state represented, Texas the only Gulf State. Only white families are included. The total number of families replying to different questions varied from 30,000 to 40,000 . Of these $47.2 \%$ report water piped to house, $21.3 \%$ have bathtubs and $16.6 \%$ a flush toilet, $27.4 \%$ have electric lights, $79.5 \%$ have automobiles, $57.2 \%$ telephones, $22.1 \%$ radios, and so on. It seems obvious that they represent the better class of farm homes rather than a cross-section of all.

Striking pictures of the bad features of rural housing are to be found in a series of bulletins issued by the Children's Bureau: Rural Children in Selected Counties of North Carolina, No. 33, 1918; Maternity Care and the Welfare of Young Children in a Homesteading County in Montana, No. 34, 1919; Maternity and Child Care in Selected Rural Areas of Mississippi, No. 88, 1921; Nutrition and Care of Children in a Mountain County of Kentucky, No. 110, 1922; Child Labor and the Work of Mothers in the Beet Fields of Colorado and Michigan, No. 115, 1923; Maternity and Infant Care in a Mountain County in Georgia, No. 120, 1923; The Welfare of Children in Cotton-Growing Areas of Texas, No. 134, 1924; A vivid summary of these findings is contained in Bernard J. Newman's paper on Rural Housing in the United States of America presented at the International Housing and Town Planning Congress in Paris, July 1928 (Part I of Proceedings, pp. 290-295):

"A survey in North Carolina showed that the Negro tenant houses had from one to three rooms, while the white farmers' houses averaged four rooms. These were small, ceiled, but 
not plastered, with window openings without sash or glass. In the mountain district, the houses were of one and two rooms, with only a fifth over four rooms. A fourth of the families slept five or more persons per bedroom. . . . In one survey in Mississippi, where the plantation system as the unit for farm management predominates, $56 \%$ of the white farmers and $89 \%$ of the Negroes were tenants. These tenants are practically hired help. Most of the cabins were of one story with three rooms. Only $4 \%$ were plastered on the interior. Numerous dwellings lacked windows and were served by open holes with shutters for stormy weather. Overcrowding was common. In fact, $40 \%$ of the families lived two or more per room, $10 \%$ of the white families slept four and five per bedroom; $11 \%$ six or more per bedroom; while cases of 9 and 10 per sleeping room were found. . . . Frontier farm conditions still prevail in sections of Montana. In the county studied, farmers lived in sod and gumbo houses, in dugouts, in log and tar paper dwellings and in frame structures, while $43 \%$ of the homes were of one room."

Thus we see that overcrowding is sometimes as serious a problem on the farm as in the city, and that lack of light and air, due to absence of windows, is not unknown. Sanitary deficiencies as to water and toilet are far more prevalent than in towns. The yard privy with box vault, often open to flies, sometimes accessible to pigs and poultry, frequently so placed as to contaminate the well water, is the usual sanitary provision. But in the more primitive districts, vast numbers of families, white as well as Negro, have no toilet facilities of any kind. In the Mississippi study cited, $61 \%$ of the white families and $85 \%$ of the Negro families had no privies. In the Montana county, where all the families were white and of an enterprising type, nearly a quarter were in the same situation. Eighty-five per cent of the families in the Georgia survey were without any sort of sanitary convenience. In a coastal plain county of North Carolina, more than half of the white families and four fifths 
of the Negroes lacked privies, and in a mountain county $90 \%$. In one of the Texas counties, $28 \%$ of white families and $75 \%$ of Negroes had neither privies, nor door and window screens, although both hookworm and malaria were prevalent.

In the face of such figures, it is difficult to maintain a complacent attitude.

\section{Home Ownership in the United States.}

We have always prided ourselves in the United States on being a nation of home owners. An owned home may be bad and a rented home may be good, but in the long run owned homes average better materially and spiritually. That is to say, the houses themselves tend to be better, and the home life within has the same tendency.

It is a commonplace to say that those who own a home have more stake in the community than those who rent,-more interest in taxes and what is obtained in return, in the quality of local government and in the character of candidates for office. They have a sense of permanency which makes them enter more fully into the community's social, religious and civic life. In addition, the ownership of property makes for conservatism, which will be regarded as an advantage or a disadvantage according to the point of view.

The gradual acquisition of a home is good training in thrift. The family either learns to save or loses its home. In spite of distinguished endorsement, some of us still regard the recent extension of installment buying to things in general as a social and economic calamity. For the purchase of a home, on the other hand, it is fully justified, under proper safeguards. If we asked families to refrain from buying a house until they had saved enough to pay for it in cash, it would 
mean waiting in most cases until the children were grown and dispersed and the acquiring couple on the threshold of old age. For every social, health and moral reason, the owned home is most important for the children's sake-while they are babies, while they are in school, while they are growing into manhood and womanhood. It is socially desirable, therefore, that the family should have the home to live in during most, if not all of the years in which they are paying for it.

It is of vital importance, however, that home-buyers in the moderate income groups should be protected from exploitation. For most of them this transaction is one of colossal magnitude which can occur only once in a life-time. There is no chance to learn by experience, to profit by one's mistakes, as may be done in buying shoes or pork chops. A bad location, a poor house plan, shoddy materials and workmanship, an unscrupulous vendor or mortgage holder may spell ruin to a hard-working couple. They need-most home-buyers need-reliable, disinterested, expert advice. Their interests should be guarded for their own sake, for their children's, and for society's.

To meet these problems of financing and of safety, such systems of help to home seekers have grown up as the Belgian and Swedish already briefly described, and that of New Zealand, or the system now being used in California for the benefit of veterans (See Chap. XIII). So large a proportion of the necessary capital is lent that the young couple need not wait many precious years to save the remainder. Repayment is spread over the whole working life if necessary. The interest rate is kept extremely low. There is no possibility of exploitation in the process. Disinterested expert advice is obtainable at every stage. Is this 
paternalism or efficiency? Is complete freedom to achieve financial ruin a particularly precious characteristic of a democracy?

American statistics of home ownership being unique, we cannot compare ourselves with other nations in this respect. An impression exists that we stand fifth in home ownership, but it does not seem possible either to verify or disprove it.

There has been a slow, but steady decrease in home ownership in the United States for some decades, and a slow, but steady increase in the proportion of mortgaged homes. The 1930 figures are not yet available.

\begin{tabular}{|c|c|c|c|c|}
\hline & \multicolumn{2}{|c|}{ Percent of total homes } & \multicolumn{2}{|c|}{ Percent of owned homes } \\
\hline & Rented & Owned & Free & Encumbered \\
\hline $\begin{array}{l}1890 \\
1900 \\
1910 \\
1920\end{array}$ & $\begin{array}{l}52.2 \\
53.9 \\
54.2 \\
54.4\end{array}$ & $\begin{array}{l}47.8 \\
46.1 \\
45.8 \\
45.6\end{array}$ & $\begin{array}{l}72 \\
68.7 \\
67.2 \\
61.7\end{array}$ & $\begin{array}{l}28 \\
31.3 \\
32.8 \\
38.3\end{array}$ \\
\hline
\end{tabular}

The percentage of owned homes varies from 37.2 in the Middle Atlantic states to 56.4 in the West North Central, and from 30.7 in the state of New York (30.9 in Georgia) to 65.3 in North Dakota. Among the cities, New York has the lowest percentage of ownership (12.7), while in the borough of Manhattan it is only 2.1. These are 1920 figures. The city as a whole will show an increase in 1930.

The ten cities with populations over 100,000 having the highest percentages of home ownership are:

$\begin{array}{ll}\text { Des Moines } & \mathbf{5 1 . 1} \\ \text { Grand Rapids } & \mathbf{5 0 . 2} \\ \text { Toledo } & 49.4 \\ \text { Omaha } & 48.4 \\ \text { Youngstown } & 47.8 \\ \text { Kansas City } & 47.6 \\ \text { Reading } & 46.6 \\ \text { Baltimore } & 46.3 \\ \text { Seattle } & 46.3 \\ \text { St. Paul } & 46.1\end{array}$


It will be observed that $50 \%$ of home ownership has been attained in only two of our large towns. Racially, it is interesting to note that in the Southern states, $49.6 \%$ of white families own their homes, and $23.8 \%$ of Negro families.

Home ownership, to be sure, is not always a desirable thing. It is a serious check on the mobility of labor. The difficulty of selling a home may anchor a man to an uncongenial job or induce him to turn his back on beckoning opportunity. It is also undesirable when it involves an excessive financial burden-when it means skimping on food or health needs, going without insurance, or lying awake nights to worry over the obligations assumed.

Thus in Philadelphia, we see an astonishing increase in home ownership during the years 1920-1925-from 39.5 to $45.5 \%$. But of the homes owned, $70.9 \%$ were mortgaged, about twice the normal percentage. What does this mean? Simply that, in the housing shortage years following the war, Philadelphia landlords, unhampered by rent restrictions, were able to force multitudes of tenants to undertake the purchase of the obsolescent houses they occupied, without regard to whether or not they would be financially able to meet their payments. Others, of course, bought new houses. The result is and will continue to be a sad crop of foreclosures. From 737 in 1920, the number of sheriff's writs issued rose to 9093 in 1928 and 11,918 in 1929 ("Housing in Philadelphia, 1929," p. 24, Bernard J. Newman, Philadelphia Housing Association).

A similar thing happened with regard to the poorly built houses which sprang up in the boroughs of Brooklyn and Queens (New York) during the tax-exemption years of post-war shortage. The purchaser was led on by smooth-tongued salesmen and pushed by high rents 
and no vacancies. Too often, he failed to realize that the cost of sidewalks and sewers not yet laid would some day be assessed against his property, or how quickly the shoddy frame and brick would need repair. Here also the aftermath of foreclosures is getting under way.

Compare the Belgian system with less than two thirds of one per cent of foreclosures in nearly forty years (Caisse Générale d'Epargne et de Retraite, Compte Rendu, 1928, p. 63).

Building and loan associations and other means of financing home ownership will be considered in Chapter XI.

\section{Minimum Standard of Housing.}

By minimum standard of housing is here meant not minimum existing standard, nor minimum legal standard, nor minimum attainable-under-existing-conditions standard, but minimum health-and-decency standard. This should be the standard provided for in wage scales or health-and-decency budgets. Obviously this standard should be obtainable by every self-supporting family, rich or poor, large or small, white or black, American born or foreign-born, throughout our land, and it should be used in calculating the amount of relief needed for those who are not self-supporting.

There has been no better formulation of what the minimum standard of housing should include than that drawn up by the National Conference of Charities and Correction in Cleveland in 1912 (Proceedings, pp. 391; 392), as follows: ${ }^{20}$

"The Right to a Home. Social welfare demands for every family a safe and sanitary home; healthful surroundings; ample and pure running water inside the house; modern and

${ }^{20}$ Also quoted by the writer in the "Housing of the Unskilled Wage Earner," p. 10. Such faithfulness to an eighteen-year-old statement does not indicate rapidly rising standards. 
sanitary toilet conveniences for its exclusive use, located inside the building; adequate sunlight and ventilation; reasonable fire protection; privacy; rooms of sufficient size and number to decently house the members of the family; freedom from dampness; prompt, adequate collection of all waste materials. These fundamental requirements for normal living should be obtainable by every family, reasonably accessible from place of employment, at a rental not exceeding $20 \%$ of the family income."

Are these excessive requirements? Do they more than provide for safeguarding life, health, morals and economic solvency? Yet it is certain that less than half the homes of our country would measure up to them. We should have to rule out about $95 \%$ of farm homes and $80 \%$ of village homes for lack of a sanitary toilet within the building and almost as many for lack of running water.

In large and small towns a varying proportion, perhaps averaging 35\%, would fall under the ban for the same defects. In such a city as New York, at least a third of the families have wholly inadequate light and air. Many of the same group have to share their toilet with their neighbors. Others are over-crowded and lack privacy. Some suffer from dampness. Among the better homes, the rental often greatly exceeds twenty per cent of the tenant's income. ${ }^{21}$

Not all of our sub-standard housing is due to poverty. Some-especially in the rural districts,-is likely to be remedied by education.

The Cleveland standard is not so high, in several particulars, as that of the housing schemes of local authorities in England and Wales, ${ }^{22}$ which provide fully

21 Where rent includes heat, this must, of course, be taken into consideration, but the margin is much too large to be covered by that in all cases.

${ }_{22}$ The Scotch standard is lower. 
equipped bathrooms, not simply toilets and running water, in single-family houses set among gardens.

This opens up a big question. With few exceptions, American authorities agree with the British and a majority of Continentals that a single-family detached house with a garden all around it forms the ideal setting for the life of growing children, and next to that comes a single-family house with a garden space front and back. Unless the cost of land and the resources of the resident are such that houses can be built far enough apart for adequate lighting and ventilation of rooms opening only at the side and for privacy in such rooms, it is far better to have small dwellings built in groups or rows. In that case, however, they should be only two rooms deep. (See discussion of standards adopted by United States Housing Corporation in Chapter I.)

In the smaller cities, the only excuse for apartments is for celibates, childless couples, and elderly people whose children have grown up and scattered. These classes are numerous enough to create a steady, though limited, demand. Newly married couples, especially where husband and wife are both working, will naturally turn to them also. And herein lies the danger, if they stay on after children are born. Normally, this should regulate itself. A yard for the children to play in, a place to hang the washing, a porch where the baby may take his nap, the possibility of unlimited noise without disturbing the neighbors, quiet rooms for the children to sleep in unwakened by music and laughter when friends drop in for the evening,-all these things draw the growing family to the single-family house.

In the large cities where land values raise economic difficulties, these same considerations draw them to the suburbs or to the outlying districts. Even in New York, it has been demonstrated that zoning regulations make it 
possible for families of moderate means to live at least in a two-family house if they are willing to travel forty or fifty minutes to work. Seattle and Philadelphia have found it possible for a large city to offer single-family houses to all economic grades.

We may grant with the enthusiasts for garden apartments that a two-room deep apartment in a building around a park-like court, with supervised play grounds and play rooms, affords a better home for a child than a dilapidated, over-crowded single-family house with out-door privy, contaminated well and a yard full of tin cans. But the comparison proves little. Multiple dwellings may be necessary in those large cities which were not planned right in the beginning. They may even be made comparatively healthful. But the child who is brought up in them carries a handicap as compared with the child who has a home of his own to shout in and a yard of his own to dig in. The most perfect garden apartment only returns him a fraction of his birthright.

In this connection, recent building permit figures from 257 American cities with over 25,000 inhabitants, may well give us pause. They are taken from the Monthly Labor Review of the Department of Labor. They refer to the number of families to be provided for in new construction during the year in question.

\begin{tabular}{|c|c|c|}
\hline \multirow{2}{*}{$\begin{array}{l}\text { In single-family houses } \\
\text { In two-family houses } \\
\text { In multi-family houses }\end{array}$} & $\begin{array}{l}1921 \\
58.3 \% \\
17.3 \% \\
24.4 \%\end{array}$ & $\begin{array}{l}1928 \\
35.2 \% \\
11.1 \% \\
53.7 \%\end{array}$ \\
\hline & 10 & 100 \\
\hline
\end{tabular}

For 1921 to 1928 the trend had been continuously away from the single family house and toward the apartment. The relative importance of the latter had considerably 
more than doubled. It is gratifying that 1929 shows a swing in the other direction, but it is too soon for much rejoicing.

\section{What is Wrong with Supply and Demand?}

With quantitatively trifling exceptions, American housing has been produced, sc far, by private business initiative, regulated by supply and demand. The system works to the extent that every one has some sort of shelter. Families are not found camping on the sidewalks. Beyond that, it is only the minimum standard set by restrictive law and the local degree of enforcement which puts any limit to the inadequacy of housing. "Demand" is by no means equivalent either to need or to desire. The only demand which stimulates supply is what economists call "effective demand"- desire plus the price in one's pocket.

The cheerful dictum of the well-fed business man, "Those people must like to live that way, or they would get out", rests on the assumption that something better is available at a price they could pay. Except for a sporadic case here and there of excessive thrift, this is far from true. Most instances of "families who have radios and automobiles instead of decent homes" involve no such choice. The radios turn out to be home made and the cars to be third-hand Fords. The remainder prove that the salesmanship of agents for cars and radios is more energetic and the arrangements for installment buying easier than in the case of homes. (See President Hoover's statement quoted in Chapter XI.)

The only part of the population which presents an effective demand for good housing is the class which can build or buy if not satisfied with the landlord's offering. This possibility stimulates the landlord to keep repairs 
up and prices down to a reasonable profit. To the extent that he meets this demand, new building is checked, and everybody below has to stay put. In times of housing shortage, this may be absolute, and the suffering extreme. When the shortage is sufficient to raise prices, building starts and will normally continue until it results in over-building, so called,-overbuilding, that is, from the builder's point of view. New houses stand vacant until the selling price drops. The purchaser may get a bargain, and some one from the lower income group may be able to move into his vacated house, after it has been empty for a time and the rent reduced. But the builder has lost money. So he knocks off building till a new shortage puts up prices again.

Builders prefer building relatively large houses and dealing with relatively well-off purchasers and do not cater to the cheaper trade even to the extent that they could. That they are not unamenable to reason, however, in this respect, is proved by the success of the educational campaign carried on by Bernard J. Newman, director of the Philadelphia Housing Association.

For several years, Mr. Newman made surveys and published figures showing the relative rate of absorption of different priced houses. In his report for 1926 (p. 33) he has a table showing that $74 \%$ of the new houses priced at $\$ 5000$ and under were sold and occupied at the end of the year, against $54 \%$ of those priced between $\$ 5001$ and $\$ 6000,48 \%$ of those between $\$ 6001$ and $\$ 7000$, and so on to the $\$ 10,000$ and $\$ 11,000$ class, where only $20 \%$ had been disposed of. He pointed out that the demand at the higher income levels was evidently nearly satisfied, while the demand farther down had hardly been tapped. He showed how many more families have low incomes than high ones. He re- 
minded the builders how quickly slow sales eat up their profits-even big ones-and how much more they would prosper with a rapid turn-over of many small houses, though the profit on each might be small. In his reports for 1928 (p. 8) and 1929 (p. 19), Mr. Newman was able to note with satisfaction a drop in average selling price from $\$ 8465$ in 1924 to $\$ 6550$ in 1928 and 6339 in 1929. In 1924, only $15.4 \%$ of new dwellings sold for $\$ 6000$ or less, whereas in $1928,35.4 \%$ fell in that class, and $5.3 \%$ sold for $\$ 5000$ or less, a few homes being marketed at $\$ 3990$.

In general, the more "to rent" and "for sale" signs, the better for tenants and home-buyers. But to do any particular family any good, the vacancies must be within range of its pocket-book, and bear a potential geographic relation to its place of employment. Vacancies at $\$ 100$ a month, or even at $\$ 50$ a month, are of no earthly use to a family with a weekly income of $\$ 25$ to $\$ 30$. And on a given income, a family with five or six children must pay much less for rent than a childless couple could afford, though their need for space and sunshine is so much greater. The big family moreover tends to pay high for what it gets because it is unpopular with landlords. Conversely, vacancies in the slums do not benefit a family looking for a comfortable home in pleasant surroundings.

The whole situation, as previously indicated, is not new and not temporary, but is bound up inextricably with our economic system. Except under pioneer conditions, where land and building materials are practically free, supply and demand, unaided, have never, at any time or at any place, furnished all classes of selfsupporting families with a minimum health-and-decency grade of housing. Nor is there any reason to suppose they ever will. 
Rentals of older homes are determined, not by their original cost, but by their replacement value,-i.e., the current price of new building. This is why a general increase of wages helps the housing situation so little. The cost of new housing promptly increases in the same ratio, and rents in the old houses, unless restrained by rent laws, follow close behind. It is a vicious circle which benefits no one except the owner of old property.

Two thirds of the population cannot pay a rental or purchase price high enough to produce a commercial profit on a new dwelling, satisfactory to the commercial builder, ${ }^{23}$ who must face many risks. Therefore, he does not build for them. This establishes a limit beyond which such efforts as Mr. Newman's cannot be expected to succeed. If this large section of the population, or any considerable part of them, are ever to live in new homes, such houses must be built on some other than a commercial basis-though not necessarily on a charitable one. There is no good reason why the commercial builder should object to this, for it would not interfere with any market which he has or could hope to have. It will, however, be in competition with landlords of old property, who will be quite certain to express themselves.

People are, nevertheless, more important than profits, and there is no doubt that social welfare demands an improvement in existing housing standards-for the lowest economic third imperatively and for the middle third if possible.

The best European practice attacks the needs of both groups simultaneously. The number of those able to live in new houses is increased by non-commercial financing schemes under government auspices which

${ }^{23}$ The justification of this particular figure will be given in the next three sections. 
permit either individual home ownership or building through coöperative societies to persons in the middle income group, whose former homes then become available for those a bit lower in the economic scale. At the same time, the worst houses at the bottom are being vacated under the restrictive law as unfit for human habitation, or torn down in the course of municipal slum clearance schemes. In the United States, where the situation is by no means so clearly recognized, efforts to meet it have been confined to our few limited dividend enterprises at the upper end and a rare demolition or closing order at the bottom.

\section{Family Income.}

The proportion of the population able to live in new dwellings is a function of family income, the part of it which can be devoted to housing, and the cost of a new home. Nothing is more important for us to know or more difficult to determine than the distribution of family income. Such information as we have refers chiefly to the individual incomes of those gainfully employed.

The standard figures for individual incomes are those published by the National Bureau of Economic Research. The following summary is condensed from "Income in the United States, Its Amount and Distribution", Table 28, p. 137, and refers to incomes of those gainfully employed in 1918, excluding two and a half million soldiers and sailors then mobilized.

$\begin{array}{ccc}\text { Income in dollars } & \text { Percent of persons } & \text { Cumulative percent } \\ \text { Under zero } & 0.53 & \\ 0-500 & 4.86 & 5.39 \\ 500-1000 & 33.35 & 38.75 \\ 1000-1500 & 33.26 & 72.01 \\ 1500-2000 & 13.89 & 85.91 \\ 2000-3000 & 8.15 & 94.07 \\ 3000-5000 & 3.68 & 97.75 \\ 5000-10,000 & 1.56 & 99.32\end{array}$


All higher incomes account for only about six tenths of one per cent of persons. Comparable tables are not given for later years. Eut in "Income in the Various States, Its Sources and Distribution, 1919, 1920 and 1921," we find the average of those gainfully employed presented in tables for those three years for the several states. For 1921, they range from $\$ 613$ in Mississippi to $\$ 1525$ in the District of Columbia, $\$ 1380$ for New York State being near the top.

The total annual income of the United States increased about $45 \%$ from 1918 to 1928 . To what extent have the lower income classes shared in this prosperity?

The most recent publication of the Bureau is "The National Income and Its Purchasing Power," by Willford I. King, 1930, which gives data up to 1928, though not in the same detailed form. From it we learn that the average income per wage earner in 1927 was $\$ 1205$ and the average income per salaried employee $\$ 2084$. The latter has been pulled somewhat out of focus for the mass of small salaried people by the inclusion of highpaid executives. The whole group of employees receive in wages and salaries about $57 \%$ of the national income. The entrepreneurs receive the rest, which in 1927 amounted to $\$ 36,845,000,000$.

Perhaps enough has been said to make clear the futility of talk about per capita income obtained by dividing the total national income by the total number of inhabitants. Thus, the per capita income in the United States for 1927 was $\$ 748$, a very impressive sum when compared with earlier periods or with other less prosperous countries at the present time, but it tells us less than nothing of the economic condition of the masses of the people. The newspapers and Rotary Clubs which get such satisfaction out of our per capita income often multiply it by five (which has not been our average size 
of family for a long time) to give what they call the income of the avera se American family. At $\$ 3740$, that sounds very well indeed, but it is a purely fictitious figure, representing only what it would be if the national income were evenly divided,- - the last thing that most of these gentlemen would advocate.

Our most difficult problem is making the transition from individual earner to family income. At first glance it seems a simple matter to divide the number of persons gainfully employed by the number of families to obtain the average numbers of earners per family, and this is, in fact, what statisticians usually do. For 1920 , that would be $41,614,248 \div 24,351,676=1.75$ nearly. For New York City at the same date, it would be just over two. When the statement was given out from the White House that there was an average of nearly one and three quarters earners to each family, this was, of course, what was meant. If all earners formed part of a family group, turning in their pay envelopes to the common fund, this would be accurate enough; but as a matter of fact, they do not. To count the total income of a boarder or lodger as forming part of the income of the family with whom he boards or lodges is utterly misleading. And this is true when the boarder or lodger is a grown son or daughter as well as in the case of a stranger. The only thing which affects the income of the family is the amount paid into its coffers by the boarder or lodger. True, the census definition of a family includes boarders, lodgers, visitors and servants. But if we think clearly, what we ought to be interested in obtaining for studying standard of living is the income of the natural family group which remains an economic unit.

If we can estimate the number of independent celibates and subtract them from the total number gain- 
fully employed, we shall have the number of earners in families. Or, we can start at the other end and try to estimate the number of supplementary earners directly.

For the sake of obtaining a serviceable estimate until a more accurate one is available, we are going to assume that all gainfully employed single persons over twenty are economically free-lance, which is not true, and that all gainfully employed boys and girls under twenty pool their earnings with the family income, which is not true either, in the belief that the two errors will approximately cancel each other.

The Census gives 1,920,281 as the number of married women gainfully employed in 1920 . Not all, however, were supplementary earners. If we deduct one quarter for those who are substituting for an incapacitated husband (about $2 \%$ of all married men), and add all the working boys and girls under twenty, we shall have:

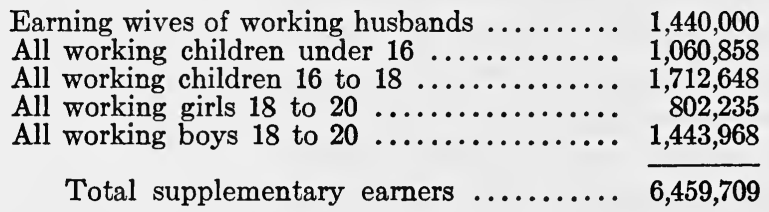

Adding this to the number of main supporters, which equals the number of families, we get $30,811,385$ as the approximate total number of earners in families in 1920 . Subtracting this figure from the total gainfully employed, we have $10,802,863$ as the approximate number of independent celibates. Dividing total earners in families by total number of families, we find the average number of earners per family to be $1.261 / 2$. In other words, there is a supplementary earner in one American family out of four instead of in three out of four. The importance of this distinction is obvious.

If we are justified in saying that there is an average 
of $1.261 / 2$ earners per American family, we are by no means justified in assuming that family income averages $261 / 2 \%$ more than the father's earnings. When the mother works, it is often part time, or she does home work, which is notoriously ill paid. The working boy or girl is by no means getting a man's wage. It is not at all likely that the family income in the United States averages more than 10 or $12 \%$ in excess of that of the principal earner.

From King's "National Income and Its Purchasing Power," already quoted, we draw, in round numbers, the following classification:

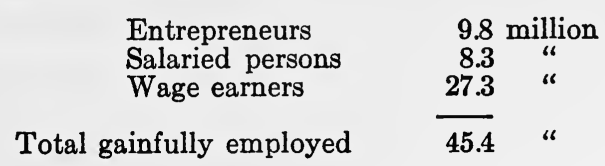

King does not give the number of families at the period with which he deals (1927), but according to the population, which he does give, it should be about 26 million.

Nearly all entrepreneurs are heads of families and, perhaps, two thirds of the salaried persons, -14 to 15 million for the two. That would leave 11 to 12 million families whose head is a wage earner.

Six million entrepreneurs are farmers. The Secretary of Agriculture, Arthur M. Hyde, recently gave $\$ 1159$ as the average income of farm families in the United States,- - not money income only, but including the retail value of farm products consumed and the rental value of the farm home. Substantially more than half of farm families would, therefore, belong in the not-to-exceed $\$ 1200$ income group.

It will be recalled that King gives $\$ 1205$ as the average (not median) wage received in 1927 and $\$ 2084$ as the average (not median) salary. More than half of the 27.3 million wage earners would receive not-to-exceed 
$\$ 1200$ and more than half of the 8.3 million salaried persons not-to-exceed $\$ 2000$.

The present writer estimates that there are about 5 million families with wage-earning head in the not-to exceed $\$ 1200$ class, the remaining 6 or 7 million being divided between the $\$ 1200-\$ 2000$ class and that above $\$ 2000$. The higher income levels would mean either that the head of the family belonged to a skilled trade, or that there were supplementary earners, or both. No doubt it is the presence of this substantial number of wage earners at comparatively high income levels which gives the business man his optimistic impression of the prosperity of the working class.

In the nature of the case, about fifteen years of married life must pass before the eldest child can go to work. If the mother has been forced by economic pressure into work away from home during that period, it is at a serious social cost to the family. Some choose one horn of the dilemma, some the other.

It is the writer's belief that the following will be found not far from true.

One third of American families have incomes not to exceed $\$ 1200$.

One third of American families have incomes between $\$ 1200$ and $\$ 2000$.

One third of American families have incomes in excess of $\$ 2000$.

To adapt this to New York City, we should have to add $25 \%$ to these averages, making the boundary lines come at $\$ 1500$ and $\$ 2500$. In view of the scarcity of farmers, it may be that the lower figure should approach $\$ 1600 .^{24}$

${ }^{24}$ The United Neighborhood Houses and the League of Mothers Clubs made, in 1928, a so-far-unpublished study of 1014 tenement house families in seven districts of New York City. They represented 
12. The Place of Housing in Family Budgets.

Of these modest incomes which most families have to get along on, even in a highly prosperous country, how much may be devoted to housing? In other words, what is the place of housing in the family budget?

There is, of course, no universally correct answer, whether we are dealing with what actually takes place or what we conceive ought to take place. The propor-

skilled and unskilled labor, small tradesmen and a few office workers. Family income ran from $\$ 900$ a year to over $\$ 2500$. The median was $\$ 1570$, or $\$ 30.19$ per week. In $50 \%$ of this group, the father was the only earner, in $7 \%$, the mother.

Reference should be made to the Report of the Commission of Housing and Regional Planning to the Governor and Legislature of the State of New York, Dec. 22, 1923, which found that in New York State approximately three-fourths of the families and in New York City approximately two-thirds of the families $(69 \%)$ had incomes under $\$ 2500$ (pp. 68, 69).

In Chicago, a study of 467 families whose heads were steadily employed unskilled or semi-skilled workers was made by Dr. Leila Houghteling of the University of Chicago for a Joint Committee representing the University, the Council of Social Agencies, and several large employers. (1927.) Family incomes of 1924 were cumulatively grouped as follows:

$\begin{array}{lr}10.7 \% \text { had under } & \$ 1200 \\ 26.8 \% \text { had under } & 1400 \\ 44 \% \text { had under } & 1600 \\ 60.3 \% \text { had under } & 1800 \\ 69.1 \% \text { had under } & 2000\end{array}$

An interesting study of family incomes in Philadelphia in 1928 was made as part of a Buying Power Survey for the Public Ledger by Dr. F. R. Cawl of the Wharton School of Finance, University of Pennsylvania. It represents an actual visit to one in ten of Philadelphia families and an effort to report accurately on occupation, and check up on its remuneration, rather than to ask questions directly bearing on income. The result, with some combining of classes for the sake of brevity, is as follows:

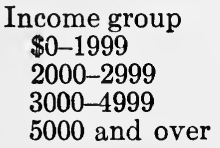

Totals
Number of Families Per cent of Families

\begin{tabular}{rr}
227,120 & 48.33 \\
126,460 & 26.92 \\
78,430 & 16.70 \\
37,850 & 8.05 \\
\hline 469,860 & 100.00
\end{tabular}


tion of the income to be devoted to the various objects varies with the size of the income and also with the size of the family. Food is an imperative necessity, relatively irreducible for a family of specified size. It occupies the largest place in the working man's budget. Housing, however, is his largest single item of expense. His food expenditure represents a large number of small purchases. A mistake here is not so serious. If the butcher or grocer gives poor value, one can try his competitor around the corner. If the marketing for Sunday dinner has been extravagant, one can atone by frugality on Monday and Tuesday. But one takes a house or a flat for at least a year. Moving is costly and troublesome. The rent bill has to be paid before food or coal or clothing is bought, or Johnny has his tonsils out or Mary goes to the dentist.

American families in the lower income groups generally divide their expenditures within the following limits:

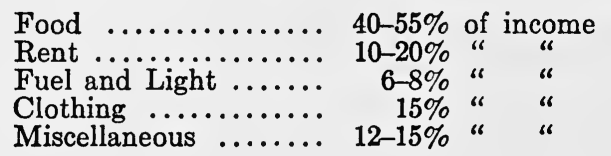

Instances of families, especially Negro families, having to spend $30-35 \%$ of their income in rent are not unknown, but admittedly involve great hardship in the other items. Those who, because of many mouths to feed, have to expend the larger amounts on food, must take the cheaper housing to make up, however inadequate it may be. Foreign countries which show a markedly higher relative expenditure for food (50$65 \%$ is common in Europe and $70 \%$ not unknown) probably have, approximately to that extent, a lower standard of living. But there is no way of making a 
precise comparison, and the amount of good housing provided on a non-commercial basis in many of these countries still further complicates the situation. ${ }^{25}$

In the middle income group, composed mostly of skilled artisans and small salaried people, we would expect some such proportion as this, permitting for the first time a real health and decency standard:

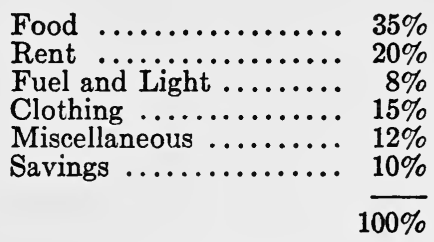

At higher income levels, further changes in proportion occur. ${ }^{26}$

Translating these percentages into dollars, on the basis of the income distribution predicated in the last section, we arrive at rentals of $\$ 10$ to $\$ 20$ per month for families at the top of the lowest economic third, i.e., with a $\$ 1200$ income, and rentals of $\$ 33.38$ at the dividing line between the middle and highest third. For a heated

25 The National Industrial Conference Board published in 1927 a study on The Cost of Living in Foreign Countries, which shows the many different ways in which the record may be kept and the relative importance assigned to the various items. It attempts no comparison of standards. The British allow $60 \%$ for food in the working man's budget and 16 for housing. The Germans allow $19 \%$ for housing and expect it to provide two rooms only. The French put housing at $11 \%$ and food at 64 . The tables sometimes shown comparing per capita income or hourly wages in different countries mean nothing, since no allowance is made for differences in distribution of income and in cost of living.

${ }^{26}$ A great many studies of actual expenditures of families at different income levels have been made, those on the largest scale for the United States by the Bureau of Labor Statistics and its predecessor, the Bureau of Labor. A convenient summary of results may be found in the chapter on Household Expenditures of "The Economics of the Household," Benjamin R. Andrews, 1923. 
apartment, fuel allowance may be added to rent, but there are no heated apartments provided for those near the bottom.

It would lead us too far afield to discuss food cost and other budget items here in order to show how nearly incompressible they become in the lower income brackets. Those who do not visualize clearly what it means to feed, cloth, warm and shelter a family on $\$ 1000$ to $\$ 1200$ a year at present price levels would do well to dip into the literature of Home Economics. The chapter on Food and the Family in Andrews' "Economics of the Household," already cited, will be found illuminating.

So far, we have spoken of rental. For the purchase of a home, it is commonly said to be possible to use rental plus savings, though whether it should be considered permissible to sacrifice life insurance and health insurance is questionable. Where there are no savings, there can be no home purchase, for rental alone is not enough, and there must also be a considerable cash payment at the start, which implies past savings.

There is a convenient rule of thumb which asserts that families should not undertake the purchase of a home costing more than twice their annual income. Not only does the effort to purchase a larger home entail excessive sacrifice to complete the purchase, but the upkeep tends to be a continuous strain, out of proportion to other expenditures. Of course, such a statement can be true only in a very general sense. On a given income, a childless couple can obviously save more than a family with half a dozen youngsters. The number of persons to be fed and clothed is, then, a highly important factor. So are the age, health, and prospects of the breadwinner. Can he count on steady employment? 
Has he reached his maximum earning power? How many more years of it can he reasonably count on? What borrowing power has he in case of an emergency? A young business or professional man, who can borrow from Dad for the mortgage payment if things go wrong, can take a chance that would be rash in the workingman, who would have to resort to a loan shark in a similar contingency. The kind of terms the purchaser can get for completing his payments has a great deal to do with it. Can he avoid the always expensive second mortgage? Can he escape the expense and uncertainty of renewals? What rate of interest does he pay? At what rate does he amortize or otherwise pay off the principal of his indebtedness? Above all, does he know that he is dealing with honorable people who will not try to take advantage of him? ${ }^{27}$

The average cost of single-family dwellings built in eighty-five large American cities during 1929 was $\$ 4902$, according to the Bureau of Labor Statistics. This was exclusive of land. Also, it was building cost, as recorded in the permit, not selling price. Mr. Newman's experience would indicate selling price as at least $30 \%$ higher. On the other hand, this is average cost, not minimum.

Now the top limit of the lowest economic group under average American conditions is $\$ 1200$, and it needs no argument to prove that a new home, with land under it, and modern improvements installed, cannot be bought, at average American prices, at the present date, for $\$ 2400$. Many would put it at $\$ 5000$, but for the sake of optimism we will call it $\$ 4500$. According to the two-times-income rule, the purchase of such a house

${ }^{27}$ These and kindred matters are sensibly discussed in the pamphlets, "How to Own Your Own Home," and "Present Home Financing Methods," issued by the Division of Building and Housing of the Department of Commerce. 
should not be attempted by a family with an income under $\$ 2250$.

Of course such a rule is far from absolute. Let us suppose a $\$ 2000$ family has been small enough and lucky enough to save $\$ 1500$ over a period of seven or eight years, and to find a new house for $\$ 4500$, also to find a Building and Loan Association willing to grant them a two-thirds mortgage loan at six per cent. Their annual carrying charges would be

Interest on $\$ 3000$ at $6 \%$

Subscription to B. and I. shares

to pay off the principal

Taxes at $2.5 \%$

Repairs, insurance, water rates, etc.
$\$ 180$

180

112.50

112.50

$\$ 585$ or $\$ 48.75$ per month

They can, perhaps, do it. The $\$ 1500$ family certainly can not. The $\$ 1800$ family, if it has no children and no illness and is good at managing, may just be able to swing it-or it may not. On the other hand, if there are a number of children, even the $\$ 2500$ family would hardly be able to make good.

Members of the building trades occupy a fortunate position in that, during periods of unemployment, they can build their own homes for the cost of materials.

Many families in the $\$ 1500-\$ 2000$ income bracket successfully purchase old homes which are cheap because unimproved or in need of repairs. Sometimes these are ultimately made very convenient and attractive.

Few single-family houses are built to rent at the present day. Our $\$ 4500$ house could not be profitably rented at less than $\$ 540$ per year or $\$ 45$ per month. This is above the proper rent limit of the $\$ 2000$ family, as it would absorb their potential savings. 
Summing up, it seems clear that the building of new single-family houses on a commercial basis is carried on almost exclusively for the top economic third of the population. If it were possible to reduce the cost of housing without reducing income a large unsatisfied demand would be tapped at once.

Except where the cost of land is very high, apartments show little economy over single-family houses, since they have to be more substantially constructed. There is enough difference, however, to permit a sprinkling of families from the upper half of the middle economic third to rent new apartments.

The statement made in an earlier section (Sec. 10) that only the top economic third of the population are able to control their environment in any real sense, because they are the potential purchasers of new homes, should by now seem clear and cogent. The ability of some families in the upper half of the middle group to pick up an old house on the bargain counter and gradually to recondition it, gives a general effect of limited control to this group which makes their situation more tolerable than that of the groups below.

\section{Four Items in the Cost of a Home.}

It is clear that the number of families who are able to live in new homes or in homes nearly-as-good-as-new can be augmented only by increasing incomes in the lower groups without increasing the cost of a new home, or by decreasing the cost of a home without decreasing incomes. As explained in Section 1, the first alternative is impossible in practice, as any general increase in wages is promptly reflected in building costs. Nor would this apply only to new houses. There is a strong tendency for owners of old houses to take advantage of increase in tenant income to put up rents in proportion. 
Replacement value, rather than actual original cost, forms the basis for calculating rentals.

We must then, if we are to have progress, lower the cost of the new home. It will help us to analyze the situation if we break up that cost into its four constituent parts:

1. The cost of the land

2. The cost of the building

3. The cost of financing

4. The profit of the entrepreneur

It is possible to get reductions at any and sometimes at all of these points. To get costs within reach of the lowest income groups, we shall need reductions all along the line.

The Veterans' Welfare Board of California, in connection with their housing work, to be described later, made a careful study of average cost distribution in a large number of small homes being marketed at $\$ 5000$ in different parts of the state, with the following result:

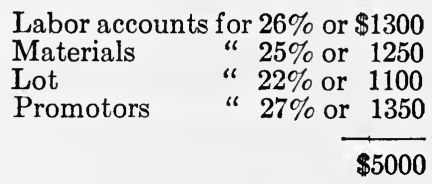

The lot is an improved one-i.e., with water, sewer, gas and electric connections on a paved street with curbs and sidewalks.

Under their fourth item, they include our third and fourth i.e., the cost of financing, the cost of selling, and the profit of the entrepreneur, which in this case certainly cannot be excessive. Our second item has been split to make their first and second.

Relative proportions would vary somewhat in dif- 
ferent sections of the country. The Californian probably gets more value for his money than the average.

It is possible for land to be so costly that none but the wealthy can afford to live on it. There is an unfortunate tendency in cities for the poorer families to be housed on very dear land, making up for it by extreme congestion and the toleration of obsolete and insanitary buildings. An effort to reduce the per capita cost for land in these sites increases the number of persons per square foot until this very congestion, as an income producer, pushes up the value of the site another peg, forcing greater congestion, which repeats the vicious circle.

The ways in which land values may be-and are being-at least partially controlled are discussed in Chapter VIII.

The cost of the building itself is generally the least reducible item. This is partly because it has been made the subject of so much intensive technical study that further possibilities (or at least probabilities) are limited.

We have ruled out reduction in building costs by reduction of wages in the building trades, for that cannot take place except as part of a general wage and salary reduction which would lower the capacity to pay of the would-be resident.

Economy through standardization, quantity production, and greater efficiency - as by cutting seasonal unemployment-is possible and highly desirable. It is chiefly in the realm of standardization that Mr. Hoover's Division of Building and Housing in the Department of Commerce has rendered noteworthy service. The elimination of hundreds of unnecessary varieties of lumber, brick, metal and plumbing parts by voluntary 
agreement among manufacturers and builders must have resulted in substantial saving.

According to a statement to the press by Ray M. Hudson, Assistant Director of the Bureau of Standards, in August 1928, the Hoover Committee on the Elimination of Waste in Industry (1921) reported 53\% waste in the building industry. As some five billion dollars are spent annually on construction in the United States, the implication is stimulating to the imagination. How great an improvement has been effected, we do not know. Whatever it is, it has been absorbed in the building trade rather than passed on to the consumer. It has made possible good wages for building trade workers, good profits for the builders, but it has not, to any appreciable extent, enlarged the boundaries of the class who can buy or rent new homes. By all means, let the process continue. Waste benefits no one. Efficiency is good. But we are still waiting to see it "do for the poor man's home what Ford did for his car."

The invention of some wholly new and much cheaper building material or building process is always possible, but we cannot afford to fold our hands while waiting for the technical experts to find it. They have been at it for such a long time! Wood and stone and brick have not changed since the time of the Pharaohs. Various European governments established experiment stations after the World War in which many forms of new building material were tested. The resulting conclusion was that in districts containing clay suitable for bricks, nothing as satisfactory has been found to be cheaper. When bricks have to be transported from some distance and there are local accumulations of cinders from gas plants and factories which can be used in the manufacture of concrete blocks, there is some economy in using them. A double wall of concrete blocks with air spaces 
between produces satisfactory results. In Rotterdam they believe they have built dry houses with poured concrete, but this is disputed elsewhere. Rammed earth was a dismal failure. A few steel houses have been built in England, but inspire no en thusiasm. They are said to be hot in summer and cold in winter, and their endurance qualities remain to be tested by time.

The classic disappointment in this line occurred some years ago when it was announced that Mr. Edison had perfected a process which would bring the cost of a modern home within reach of the humblest laborer. It was a poured concrete system by which the entire housewalls, roofs, floors, partitions, window jambs, stairs, bathtub and picture molding - was to be poured in one operation. The houses so produced did not prove satisfactory. People did not like to live in them. They were never produced in sufficient numbers to make them cheap, though that feature could probably have been achieved in large-scale operations.

One of the best experiments carried out along this line was by C. J. Ingersoll, the watch manufacturer, who first put up 40 all-concrete poured houses for his employees at Union, N. J. containing four rooms and bath, followed by 25 of the same at Phillipsburg, N. J. and 50 containing six rooms and bath. These operations occurred in 1918 and 1919.

The cost of financing a home is the profit made by the institution or individual who lends the money for it. This is only one of a whole series of profits which every house represents. That of the speculative builder is only one, for before him were contractors, sub-contractors, material men, land owner and subdivider, and after him follows the landlord.

Speculative builders operate on a credit basis. They spread their working capital as far as it will stretch, 
seeking profit in the size of their undertakings and in quick turnover. In addition to the conservative first mortgage on which they usually pay $6 \%$ interest, they carry a second mortgage on which they are in effect, through the discount and bonus system, paying 12 $15 \%$. The more speculative pile up a third and even fourth mortgage, on which the rates are fantastic. Naturally, it is the purchaser who pays for this in the first place and the tenant ultimately.

The New York Commission of Housing and Regional Planning, in its 1926 report (p. 35) found that of each dollar paid by the New York apartment house tenant in rent, 54.7 cents go to pay interest on the various mortgages and on the owner's equity, and that only 16.6 cents are used in amortizing the principal. Where owner's profit is at the same rate as interest, as in the case of limited dividend companies, cutting the rate of interest in half would permit a reduction in rent of $27.3 \%$.

Limited dividend housing does not eliminate the profits of contractors and material men. It reduces interest charges by cutting out junior mortgages and it reduces the indeterminate profit of the speculative builder to a voluntarily accepted 5 or $6 \%$ on the money invested. The lower interest rates on foreign housing loans make their reduction greater. Municipal housing involves no profit-after the contractor gets hisbut as all of the money is borrowed and must be returned with interest, ${ }^{28}$ the effect is much the same as in the case of a limited dividend company except that it can usually amortize more slowly. Subsidized housing goes a step further, of course, to bring down the cost to the consumer. Tax exemption is a form of subsidy. low.

${ }^{28} \mathrm{Vienna}$ furnishes the exception. Her rentals are correspondingly 


\section{Introduction}

With the foregoing general considerations in mind, we should be prepared to take up the story of the last fourteen years in American housing. An effort will be made to show characteristic trends and tendencies rather than a detailed picture of everything that has occurred in all parts of the country during the period. 


\section{CHAPTER I}

\section{WAR HOUSING ${ }^{1}$}

IT is safe to say that had it not been for the quality and type of British war housing, our own would have been of the temporary barracks variety. And we should have known little of what the British were doing without the foresight of Charles Harris Whitaker, editor of the Journal of the American Institute of Architects, who sent Frederick L. Ackerman to England, shortly after the American declaration of war in 1917, to gather information. Mr. Whitaker's strong editorials and Mr. Ackerman's illuminating articles, accompanied by full ground plans and beautiful photographs of the Ministry of Munitions' extensive housing developments at Well Hall, Woolwich, and at Gretna and Eastriggs in Scotland, established a collection of reference material in the pages of the Journal of the American Institute of Architects which could hardly be ignored.

Here were the British, with the war at their door, using their best town planning and architectural talent to lay out complete garden villages and fill them with attractive cottages of permanent construction in which their war industry workers could settle down to a normal, wholesome family life. Naturally, the British would not have achieved these standards if it had not

1 As "The Housing of the Unskilled Wage Earner" dealt with housing events up to the Armistice, a certain overlapping is involved here. But the war experience is so obviously the dividing line between two eras that what followed would not be comprehensible without it. 
been for their pre-war experience in publicly built and owned cottage estates. But what interested the Council of National Defense and ultimately Congress was that they had developed an efficient system of warmaterials production and that good housing for the workers was one of the means employed.

The Council of National Defense had been created in the summer of 1916 as a precautionary measure. Samuel Gompers, member for labor, and chairman of a committee which covered health and welfare as well, realized early in 1917 how the lack of housing would hamper the sudden expansion of war industries, and appointed a sub-committee on housing in May of that year, with Philip Hiss of New York as chairman. Questionnaires on existing housing supply were sent to 200 cities and Mr. Hiss traveled extensively over the country collecting first-hand information. Various experts, called together for conference at the end of August, decided that the provision of housing for workers in the new war industries would prove too great a task for private capital and private enterprise and that the Government would have to intervene. This conference also recommended that permanent housing of good quality would be the best economy in the long run for the Government as well as best for the workers.

The battle was not won without a struggle. It had to be made abundantly clear that this was a war policy only and did not commit the Government to anything in peace time. The bunk house idea died hard. Owners of obsolete tenement property protested that they would be ruined by the competition. It would be all right for the Government to subsidize the transportation lines to bring workers from a distance, but highly dangerous and subversive for it to accept any loss through housing operations. 
In October 1917, the Council of National Defense appointed another committee with Otto M. Eidlitz of New York as chairman, which reported that an emergency existed, that it was impossible to bring into being great new centers of war industry without at the same time providing housing for the workers, and that an organization with broad powers would have to be created to acquire real estate and conduct building operations. It also recommended, in view of the probable duration of the war and the ultimate sale value to the Government, that methods of permanent construction be used and that standards be kept high.

On November 30, the National Housing Association sent a strong letter to President Wilson in the same vein.

In February, Congress appropriated $\$ 50,000,000$ for housing of workers under the Shipping Board. This was later increased to $\$ 75,000,000$. In May, $\$ 60,000$,000 was appropriated for the housing of other war workers, to be administered by the Department of Labor. In July, $\$ 40,000,000$ was added. At the same time the United States Housing Corporation was created to carry on the work under the Department of Labor. The Shipping Board thus had the advantage of several months earlier start over the Housing Corporation.

The methods of procedure adopted by the two organizations differed widely. With a few exceptions, the method followed by the Shipping Board (Emergency Fleet Corporation) was to lend the necessary money to realty companies incorporated by the ship-building companies, which provided the land, the loans being secured by blanket mortgages covering the land and improvements. ${ }^{2}$ It was expected that the realty companies

2 This statement is taken from a letter of J. Caldwell Jenkins, Vice President of the United States Shipping Board Merchant Fleet Corporation, to the author, dated June, 2, 1930. 

would ultimately repay the loans and own the housing developments after the Government had written off excess war cost. A. Merritt Taylor was head of the Division of Transportation and Housing which had these matters in hand, and Frederick L. Ackerman had charge of its architectural work, which was of particularly high character.

The United States Housing Corporation, on the other hand, built and administered directly. Otto M. Eidlitz was its president, as well as director of the Bureau of Industrial Housing and Transportation in the Department of Labor, under which it operated.

One of the early acts of the Bureau of Industrial Housing, before the creation of the Housing Corporation, was to draw up a set of "Standards Recommended for Permanent Industrial Housing Developments," which were printed in a 15 page pamphlet dated March 1918. These were basically the work of Lawrence Veiller, secretary of the National Housing Association, discussed and modified by a group of architects, town planners and others.

The following quotations are illustrative:

"These standards are not intended as inflexible requirements, but any plans which fail to conform to them are not likely to be accepted unless supported by very strong reasons. Local building codes, housing laws and similar ordinances are to be followed: Provided, however, that in case such local regulations permit or require anything not permitted by these standards the express approval of the bureau is to be obtained before departing from the standards as here outlined.

"Tenement and apartment houses are considered generally undesirable and will be accepted only in cities where, because of high land values, it is clearly demonstrated that single or two-family houses cannot be economically provided, or where 
there is an insistent local demand for this type of multiple housing. ....

"Materials of Exterior. Materials dependent on local supplies; brick, terra cotta, stone or concrete preferred; . . . but wood frame clapboarded, shingled or stuccoed permitted for detached and semidetached (single-family or two-family) houses not over $2 \frac{1}{2}$ stories high. . . . Roof to be fire resisting. ... .

"Row or group houses normally not to be more than two rooms deep. No living quarters to be in basements. ... Every bedroom to have a clothes closet, opening from the room. ... Cooking. Gas preferred, but flue for coal stove to be provided. Lighting. Electricity preferred. Open Spaces. Side yard between adjacent buildings to be preferably 20 feet; minimum 16 feet. . . . Rear yard depth to be not less than height of building. ... Minimum distance between backs of houses to be 50 feet. . . . Front yards or set-backs desirable when practicable. . . .

"Out door water-closets will not be accepted. Privies will not be accepted. ... Bathtub (shower is not sufficient), Lavatory to be preferably in bathroom. Sink to be in kitchen; rim 36 inches above floor. Washtubs with covers, preferably two, rim 36 inches above floor, to be set in kitchen or in well-lighted dry, and ventilated cellar.

"Rooms, Number and Use of. For higher-paid workers, 5 -room type preferred, with parlor, large kitchen, 3 bedrooms and bathroom. . . . For lower paid workers, 4-room type desirable, with parlor, kitchen, two bedrooms and bathroom."

The only items in these quotations, or in much more not quoted, which are fairly open to criticism are contained in these last sentences. The backward stage of American opinion-even among the enlightened-is strikingly revealed in thus making the number of bedrooms depend, not on the size of the family, as would be the case almost anywhere in Europe in a government housing project, but on the size of the income.

In general, however, the standards proved very useful in Housing Corporation developments, and while 
the Shipping Board group never formally adopted them, their influence was clearly perceptible in that quarter.

Beside the United States Housing Corporation and the Emergency Fleet Corporation, extensive housing schemes were carried out by the Ordnance Department, which created sixteen new communities in isolated districts for the manufacture of explosives, the largest of which at Old Hickory, Tenn., housed over 10,000 workers. Here the construction was all of a temporary character. Ready-cut houses and a large proportion of dormitories were used, as it was not believed the communities would continue after the restoration of peace. The establishment of schools, churches, social and health centers, as well as shopping facilities, in these temporary towns presented interesting features, but throws little light on permanent family housing problems. Altogether, some 45,000 persons were housed by the Ordnance Department.

The work of the Housing Division of the Emergency Fleet Corporation is summarized in the accompanying table taken from the report of its chief, A. Merritt Taylor, to a Senate Committee, January 10, 1919. It represented projects which averaged $81 \%$ complete and which he recommended should be carried out. He said that this housing would provide for 55,000 persons, including women and children, and he anticipated that the ship-building companies would take over the completed developments with little loss to the government. He estimated total government expenditures for housing of shipyard workers at $\$ 66,883,845$.

Meanwhile the United States Housing Corporation had been exceedingly active. So much preliminary work had been done before July 25, 1918, when its appropriation first became available, that during the 109 
Amer. Intern'l S. B. Co., Hog Island, Phila. (4 projects)

Newport News S. B. and D. D. Co., Newport News, Va. (2 projects)

New York S. B. Co., Camden, N. J. (4 projects) .

501

Bethlehem S. B. Corp., Sparrows Pt., Md. (2 projects) . 1662

Atlantic Corporation, Portsmouth, N. H. . . . . .

531,296

Sun Shipbuilding Co., Chester, Pa. (2 projects) . . .

276

713

Chester Shipbuilding Co., Chester, Pa. (2 projects) . . 278,1 B. H.

American Shipbuilding Company, Lorain, Ohio . . .

Texas Shipbuilding Co., Bath, Maine . . . . . . . 109

Bethlehem S. B. Co., Wilmington, Del., and Pusey and Jones

Merchants S. B. Corp., Bristol, Pa. . . . . . . . . . Pusey and Jones, Gloucester, N. J. . . . . . . .

Westinghouse E. and M. Co., Essington, Pa. (2 projects) 200

Merrill-Stevens S. B. Co., Jacksonville, Fla. . . . . 158

Bayles Shipyard Inc., Pt. Jefferson, L. I. . . . . . . . $\quad 9$

G. M. Standifer Constr. Co., Vancouver, Wash. . . . 107

Terry Shipbuilding Co., Savannah, Ga. . . . . . . 120

Traylor Shipbuilding Co., Cornell Heights, Pa. . . . Tents

Detroit Shipbuilding Co., Wyandotte, Mich. . . . . 78

Manitowoc S. B. Co., Manitowoc, Wis. . . . . . . 100

Groton Iron Works, Groton, Conn. . . . . . . . . 52

Newburgh Shipyard Inc., Newburgh, N. Y. . . . . . . 127

Pacific Coast S. B. Co., Clyde, Cal. . . . . . . . . 105

Missouri Valley D. and I. Co., Quantico, Va. . . . . 10, 3 B. H.

Total 
CORPORATION - DIVISION OF PASSENGER TRANSPORHOUSING DEPARTMENT

cluding Character of Housing and

Men Housed.

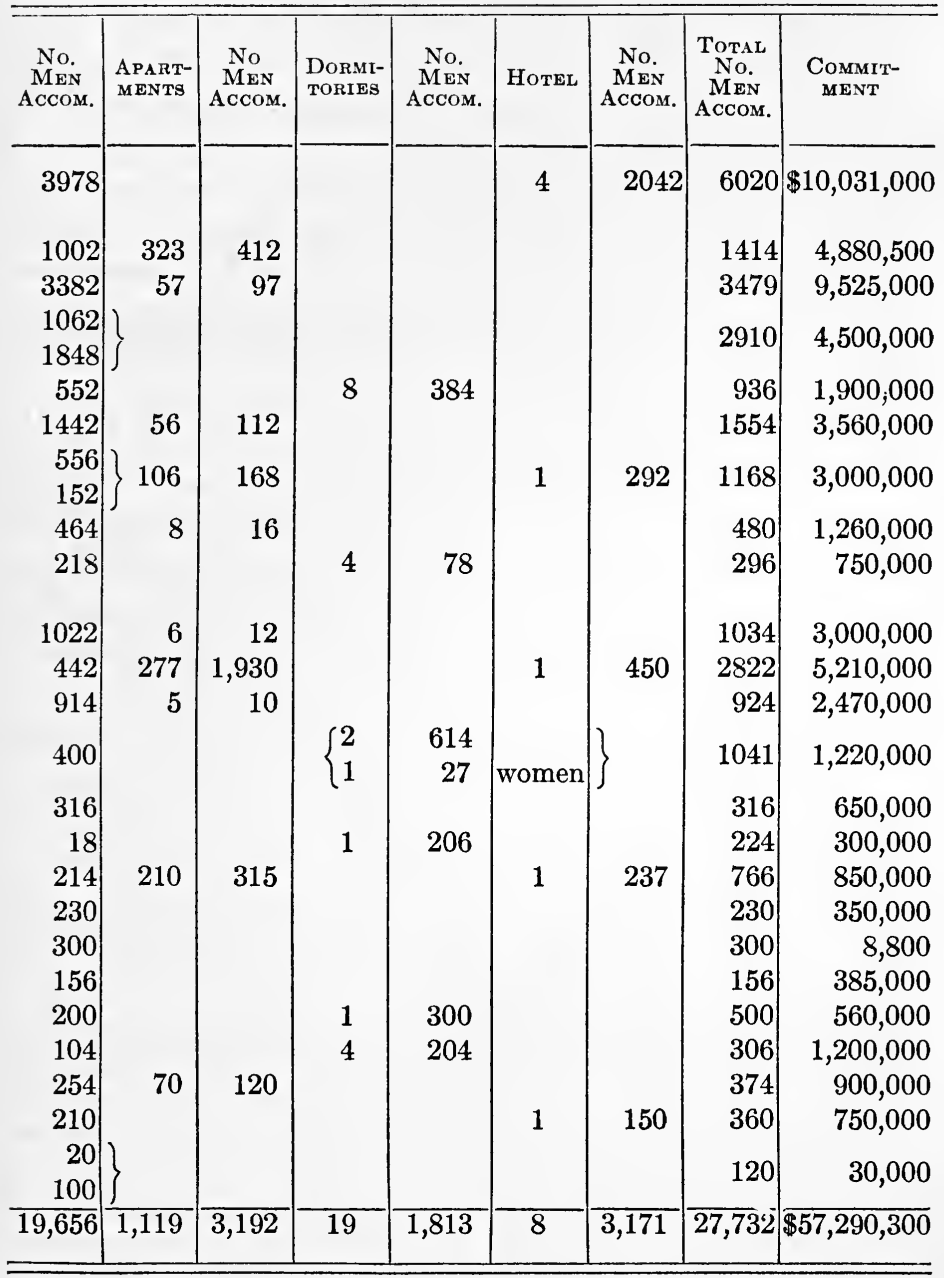


days from that date to the signing of the Armistice, plans were gotten under way for 128 sites in 71 communities. For 83 of these projects, specifications were completed, for 60 contracts were let, and in 40 construction was already started. (Vol. II, Report United States Housing Corporation, 1919, Henry V. Hubbard, Editor.)

The Armistice did away with the reason for all this. Where contracts had not been made, plans were at once dropped. Where work had not started, contracts were cancelled. Projects not well advanced or not likely to be useful in peace times were abandoned. Others were curtailed.

The following summary table taken from the Report of the United States Housing Corporation, 1919, Vol. II, p. 386, shows the scope of projects before the Armistice and the extent to which they were afterwards cut. It also shows how great was the housing need. The amount of housing proposed before the Armistice, it will be observed, was only half the family accommodation and three-fifths the accommodation for single workers which the bureau's investigations showed to be required after taking care of as many as possible by "saturation" and "transportation." Had the war lasted longer, there would doubtless have been further plans and additional appropriations to meet these unmet needs. ${ }^{3}$

In an earlier report of the Housing Corporation to the Secretary of Labor, bearing date of December 3,

${ }^{8}$ By "saturation" is meant the fuller use of existing vacancies, including in Washington and Bethlehem several hundred cases of requisitioning. Home registries for recording all vacancies,-houses, flats and rooms,-were established in 66 cities, and canvasses preliminary to the establishment of registries were going on in 41 more. Publicity campaigns were carried on urging people to take war workers into their homes as a patriotic duty. By "transportation" is meant making available existing vacancies in neighboring towns by creating transportation service. 


\section{UNITED STATES HOUSING CORPORATION}

\section{Table I. Housing Need and Provision}

Estimated housing need, workers to be accommodated under full war program

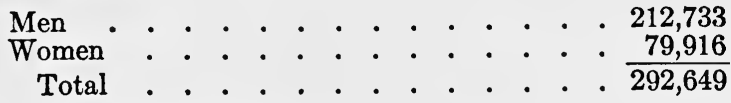

Workers to be accommodated

By saturation . . . . . . . . . 71,035

By transportation : . . . . : . $: 55,530$ Total

Workers remaining to be housed . . . . .

Number of families to be housed . . . . . 50,350

Number of single workers to be housed . . . 52,850

Construction recommended by investigators:

Families in houses . . . . . . . . . 24,539

Quarters for single workers . . . . . 32,651

\begin{tabular}{|c|c|c|}
\hline Housina Program, 128 Sites & $\begin{array}{c}\text { Proposed Nov. 4, } \\
1918\end{array}$ & $\begin{array}{c}\text { REvised APR. } 18, \\
1919\end{array}$ \\
\hline $\begin{array}{l}\text { Number of families, including } 3,965 \text { families } \\
\text { on sites for which plans were not made } \\
\text { Number of single workers . } \\
\text { Number of families in permanent bldgs. } \\
\text { Number of families in temporary bldgs. } \\
\text { Number of single workers in perm. bldgs. } \\
\text { Number of single workers in temp. bldgs. } \\
\text { Number of families in houses. } \\
\text { Number of families in apartments } . . \\
\text { Number of families in ready-cut houses } \\
\text { Number of families in sectional houses } \\
\text { Number of single workers in existing hotels } \\
\text { Number of single workers in new hotels } \\
\text { Number of single workers in dormitories } \\
\text { Number of single workers in buildings con- } \\
\text { vertible into houses } \\
\text { Number of boarders in family houses. }\end{array}$ & \begin{tabular}{|c|}
24,970 \\
12,865 men \\
11,132 women \\
24,218 \\
752 \\
$2374 \mathrm{M}, 2435 \mathrm{~W}$. \\
$10,489 \mathrm{M}, 8697 \mathrm{~W}$. \\
22,391 \\
2,579 \\
1,702 \\
336 \\
$591 \mathrm{M}, 815 \mathrm{~W}$. \\
$583 \mathrm{M}, 3566 \mathrm{~W}$. \\
$11,125 \mathrm{M}, 5693 \mathrm{~W}$. \\
$324 \mathrm{M}, 1425 \mathrm{~W}$. \\
$767 \mathrm{M}, 1058 \mathrm{~W}$.
\end{tabular} & $\begin{array}{l}6,148 \\
4,932 \\
3,375 \\
6,148 \\
594 \mathrm{M}, 302 \mathrm{~W} . \\
4338 \mathrm{M}, 3073 \mathrm{~W} . \\
5,055 \\
1,093 \\
267 \\
944 \mathrm{M} . \\
350 \mathrm{M}, 1944 \mathrm{~W} . \\
4338 \mathrm{M}, 1301 \mathrm{~W} . \\
172 \mathrm{~W} . \\
130 \mathrm{~W} .\end{array}$ \\
\hline
\end{tabular}


1918 , it was stated that $\$ 45,000,000$ would cover all present and proposed expenditures for construction under the Corporation, and that $\$ 4,000,000$ of this represented the cost of canceling contracts already made.

Total contracts awarded $\ldots \ldots \ldots \ldots \ldots \ldots . \$ \$ 63,481,146$

Reduction effected ................. 25,056,231

Approximate final costs ............. $\overline{\$ 38,424,915}$

To the last figure $15 \%$ was added for contingencies.

Prompt and efficient as the Housing Corporation had shown itself in speeding action when action was needed and in cutting it down when no longer required, the Senate permitted itself to be persuaded, in the name of economy, to adopt a resolution, a month after the Armistice (Dec. 12), requiring the Housing Corporation to suspend work at once on all projects not $75 \%$ complete and to dispose of all unfinished schemes for whatever they would bring. The Committee on Public Buildings in the House was apparently about to report the resolution favorably when an aroused public opinion began to make itself felt. The housing shortage, due to war-time suspension of normal building, was already pinching. Small, modern homes were greatly in demand. It was obvious that bidding on unfinished buildings would be limited to a few professionals and that the prices obtained by the Government would be proportionately as well as absolutely much lower than if the houses were finished and sold individually. The home-purchaser, moreover, would get his house cheaper from the Government than from a dealer. The only parties gaining from the proposed liquidation would be the real estate promoters who would buy at a low figure from the Government and sell at a high one to the home-seeker.

The National Housing Association was particularly 
active in calling attention to the matter and stirring up protests, but the American Institute of Architects, the American Federation of Labor and other organizations took a hand, as did the Army, Navy and Labor Departments. The action finally taken by Congress reflected these currents. Twenty-odd projects were allowed to be finished, but it was stipulated that the property should be sold at its fair market value as soon as could be advantageously done, and that the Housing Corporation should then wind up its affairs and dissolve. A provision of real social value was that a reasonable effort should be made to sell the houses direct to prospective individual home owners for their own occupancy before they were offered for sale in bulk or to speculative investors (66th Congress H. R. 7343). The successful carrying out of this policy will be reverted to later. ${ }^{4}$

A year after its first attack, Congress was still showing hostility toward the Housing Corporation. The Senate Committee on Public Buildings and Grounds employed a lawyer as investigator who made a report so obviously ex parte that nothing came of it after the Committee signed and printed it. In it, the Housing Corporation was scored for building permanent instead of temporary houses. It was scored for building better houses than workers were accustomed to, for wasting time on town planning, planting and "orientation", in quotation marks, as if it were a term of reproach. The officials of the Housing Corporation were charged with

${ }^{4}$ Housing Corporation projects were carried out at the following: Aberdeen, Md.; Alliance, O.; Bath, Me.; Bridgeport, Conn. (6 sites); Charlestown, W. Va.; Erie, Pa.; Hammond, Ind.; Indianhead, Md.; Mare Island, Calif.; New Brunswick, N. J.; New Castle, Del.; New London, Conn. (2 sites) ; Newport, R. I.; Niagara Falls, N. Y.; Niles, O.; Norfolk, Va. (2 sites); Philadelphia, Pa. (Oregon Ave.); Pompton Lakes, N. J.; Portsmouth, N. H.; Puget Sound Navy Yard, Wash.; Quincy, Mass. (3 sites); Rock Island District, Ill. (6 sites); Seven Pines, Va.; Tullytown, Pa.; Washington, D. C. (3 sites) ; Waterbury, Conn.; Watertown, N. Y.; Woodbury, N. J. 
being "engaged in making a demonstration of model housing". "Congress certainly did not intend, whatever may have been the intention of the Housing Corporation, to enter into competition in architectural poetry with any other nation or private organization. ... We do not believe that this was necessary for the loyal mechanics who were to be housed. They would not have complained of the color of the houses, or of the curve of the dormer windows, or of the 'orientation' of the blocks." A general charge of extravagance was made, but was not borne out by the facts alleged. ${ }^{5}$

What was the cause of this persistent hostility toward the Housing Corporation and the entirely different attitude toward the Housing Division of the Fleet Corporation? Obviously, the Emergency Fleet Corporation was in a better strategic position because its work was farther advanced. This would account for some difference in results, but not for the difference in attitude. Was it not, perhaps, the bugbear of government housing that was the real object of attack? The Shipping Board projects were only a war variation of the familiar employer's housing through a subsidiary holding company. The shipbuilding companies or their subsidiaries owned the land and managed the houses. The fact that the Government had provided the money for the houses, supervising their lay-out and architecture, and held a mortgage on the property, did not

5 According to this actively hostile report, the average cost per single-family house was $\$ 5,673.78$, including, presumably, land and improvements. According to the Housing Corporation's figures embodied in Vol. II of its 1919 Report, p. 389, the average cost per house alone was $\$ 4,374.70$ (30 cents a cubic foot), or with land and improvements directly chargeable to it, $\$ 5,108.93$. With its share of general improvements outside the project and of buildings other than houses, it was $\$ 5,398.11$. These prices were higher than those of the pre-war period, but not higher than those which followed the war. There was no conceivable way for home-building to avoid the general high level of wages and materials prices, though doubtless the war need of speed prevented some minor economies which might otherwise have been effected. 
worry any one very much. But the projects under the Housing Corporation were government owned, government built and government managed. There had been scattering talk, especially in labor circles, of making the housing activities of the Government permanent and of starting similar agencies in states and cities. Were the owners of obsolete housing and speculative builders of the jerry type alarmed? Was this the real source of the offensive? If so, while they failed to discredit the Housing Corporation or to throw its partly finished projects into the hands of speculators, they were entirely successful in preventing the continuance of the Bureau of Industrial Housing, even as a source of information.

In regard to the ultimate disposition of the Shipping Board housing projects, Vice-President Jenkins' letter, previously cited, may be quoted as follows:

"The total cost to the Government of these housing developments was approximately $\$ 69,300,000$. The total sales prices, including purchase money mortgages taken, was approximately $\$ 25,450,000$.

". . . Eight of these blanket mortgages, ${ }^{6}$ totalling approximately $\$ 14,140,000$, were sold to shipbuilding companies for cash or assigned to them in general settlements for an estimated total of $\$ 4,188,500 \ldots$.

"Nine of the projects were sold at public auction, probably a majority of the houses in these cases being purchased by individual home seekers and a large number by real estate firms and others for investment or speculative purposes. One entire project and about half of another were sold at private sale to individual purchasers.

"We are unable to state with exactness the average price per home paid by individual home seekers, but this would probably be about $\$ 2,800$. $^{7}$

- Mortgages held by the Shipping Board. See previous reference to this letter.

${ }^{7}$ In reply to a question, Mr. Jenkins said that this price included the land. 
"In the sales at public auction, purchasers were required to pay a total of not less than $30 \%$ in cash and were given the option of allowing $70 \%$ to remain on purchase money mortgage at $6 \%$ interest, $60 \%$ to remain at $51 / 2 \%$ or $50 \%$ to remain at $5 \%$. We still hold some of these mortgages.

"In the private sales to individuals a $10 \%$ cish payment was required. A purchase money first mortgage for $60 \%$ of the purchase and a second mortgage for $30 \%$, both bearing interest at $6 \%$, were accepted in payment of the balance. In such cases, the second mortgages were payable in installments. All the mortgages taken in these sales were subsequently sold by the Shipping Board for cash."

It will be observed that the Government has recovered approximately $37 \%$ of its expenditures for the housing of shipyard workers.

According to a letter from Mrs. Lulah T. Andrews, President of the United States Housing Corporation, dated April 2, 1930, that organization has recovered about $48 \%$ of its expenditures. This comparison is made, not as a reflection on the Shipping Board, but as showing how little foundation there was for accusing the Housing Corporation of extravagance. Most wartime expenditures were all outgo and no income at all. In both instances, the primary object-expediting war industry by providing comfortable housing for war industry workers-was efficiently achieved.

As to the disposition of the Housing Corporation's property, Mrs. Andrews says: "No sales were made to speculators, and none to development companies until after all efforts had been exhausted to dispose of the properties to individual purchasers, direct. Sales were not made by the medium commonly known as 'public auction'."

Of the 6148 family units completed, 452 were transferred to other government departments for the use of their employees and the rest-5696-were sold to in- 

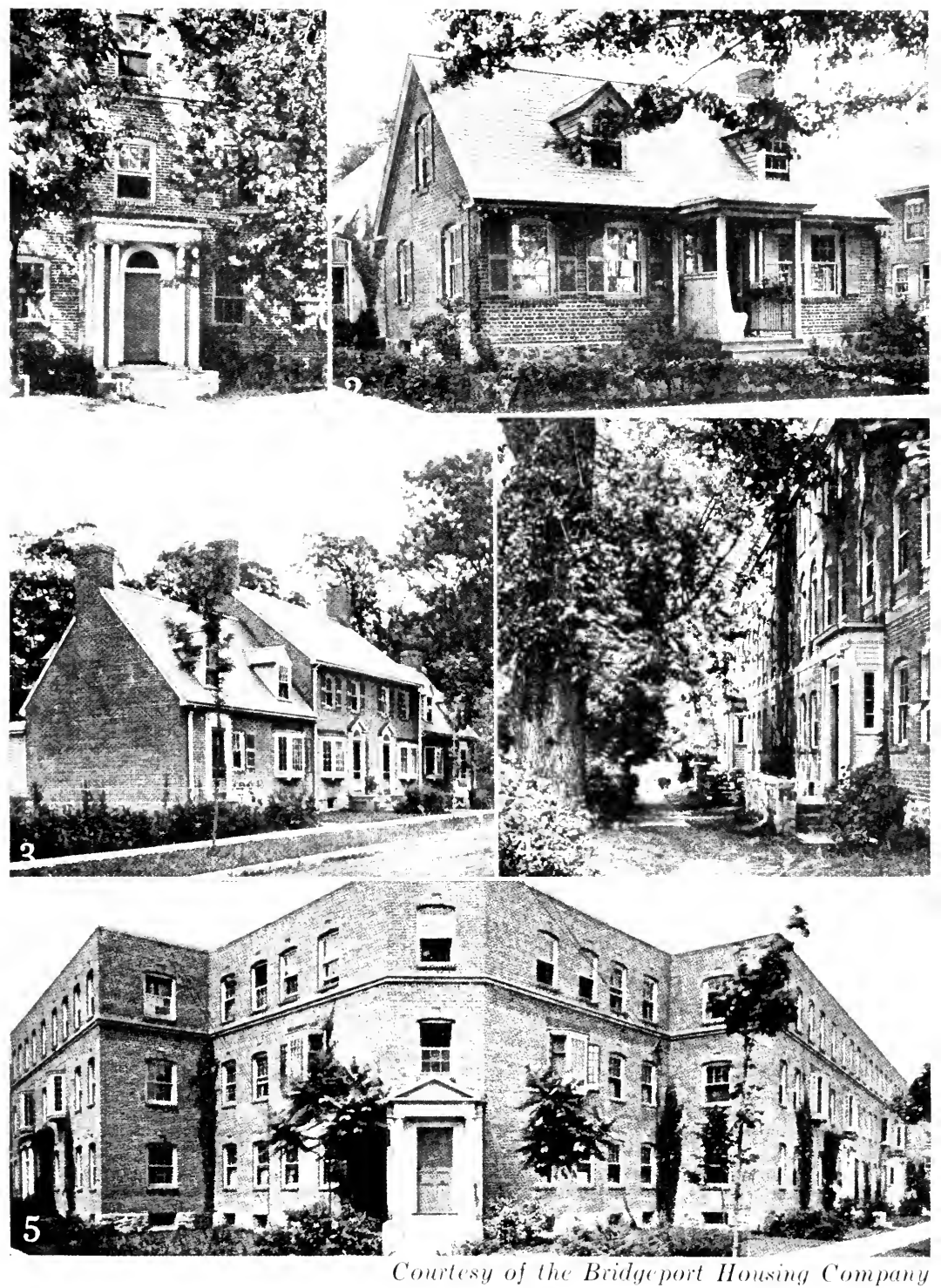

Government housine for munition workers, (Lnited States Housing Corporation,) Bridgeport, Conn. R. Clipston Sturgis, architect. 1. Doorway of apartunent house. 2. Six-room detached house. 3. Group of four houses. 4 and 5 . Apartments. 

dividual home seekers at an average sales price of $\$ 3165$ each. Preference was given to the workers already in the houses if they had shown themselves good tenants and likely to be responsible purchasers. As provided by Congress, sales were made only to American citizens. Mrs. Andrews' impression is that the majority of the purchasers were skilled industrial workers, but no effort was made to confine sales to any occupational or economic group.

In general, sales of improved properties were made on the basis of $10 \%$ cash down payment, and $1 \%$ monthly, covering installments of principal and $6 \%$ interest on balance remaining unpaid.

"Comparatively few purchasers paid cash for their homes, and as for the remainder, purchase money notes and mortgages for outstanding balances were executed by them to United States of America, direct. In many instances, however, purchasers have refinanced their debts after they had been reduced to notes and mortgages, and have paid the Government in full.

"The work of the Corporation at this time consisted largely in the making of collections on balances outstanding under notes and mortgages and depositing the same with the United States Treasury."

It is evident that the Government carried on very large scale housing operations of a high character. Housing was provided for 45,000 persons by the Ordnance Department, 55,000 by the Shipping Board and (on the same basis of calculation) about 38,000 by the Housing Corporation. In permanent structures and largely in single family dwellings, the Shipping Board and Housing Corporation together provided for something over 16,000 families. Had the war lasted another year, the volume of construction would have been greatly increased. 
Repeating that the primary object of war housing was to help win the war, what useful results, if any, has it had as by-products?

1. Standards of house design and subdivision layout have been substantially raised all over the country. Our best architects and city planners gladly served with the Shipping Board and the Housing Corporation. The new towns and subdivisions which they created are widely distributed on the Atlantic and Pacific Coasts and to some extent in the interior. Their effect on subsequent commercial building and platting has been marked, although chiefly for the benefit of higher economic groups.

2. The standard of living of the war workers was in most cases substantially raised by the convenient and attractive modern houses which they occupied. Some of them were able ultimately to purchase these homes. Some of the shipyard workers still occupy them on a rental basis. The rest must surely have had their ambition for a good home and their understanding of what makes a good home stimulated by their sojourn in the government houses. Had the war lasted longer, this effect would doubtless have taken deeper root.

3. It proved that government housing could be produced and administered in the United States without scandal, without extravagance, without the sky falling, or the constitution going on the scrap heap. 


\section{CHAPTER II}

\section{THE HOUSING SHORTAGE}

THe failure to conserve war gains in housing standard and to push them farther was due in part, at least, to the general post-war reaction from all forms of idealism to a frankly self-centered materialism. Such concepts as human brotherhood and social justice went into the discard in the de-bunking process. The boys in the trenches and their anxious folks at home had been breathing a rarified atmosphere of self-sacrifice-utterly real while it lasted-which was evidently a strain, if one may judge by the haste with which most of them scrambled down from it before the ink was fairly dry on the Armistice. Business had accepted during the War an unaccustomed and uncomfortable degree of government control. Naturally, it was eager to revert to the good old days of laissez-faire.

If general public opinion had been farther advanced so that the working people themselves knew just what they wanted in the way of housing and how it could be secured, as was the case in England, for instance, their self-centered materialism might have served as a lever to force their standards up. There were enough of them to out-vote the self-centered materialism of landlords, builders and real-estate promoters. As it was, their ideas were vague, their scattered efforts lacked effectiveness as to housing and were soon concentrated on the old subject of wages, with which they were much 
more familiar. The building trades, being among the best organized, were able to secure the biggest advances, and so the cost of building increased somewhat more than the average rise of wages or the general cost of living.

This circumstance aggravated another important factor, which came to dominate the housing situation during the next few years, diverting attention from quality to quantity, and making it supremely difficult even to speak of raising standards-the post-war shortage.

The housing shortage at the end of the War came as a surprise to most of the people in the United States. Before the War there had been in our country an average annual urban production of about 400,000 new dwellings, which took care of replacements and increase of population. In 1917 and 1918 almost no building was done except by the Federal Government. Private building was expected to resume briskly as soon as the War was over. It started to do so, but halted. The cost of a home-labor and materials-had doubled. Would people pay the increased price? Few cared to do so, even if they could, as a sudden deflation in prices might wipe out half their investment.

The volume of home-building in 1919, instead of reducing the shortage, was only $58 \%$ of normal. That of 1920 reached only $37 \%$ of normal. There was by that time a numerical shortage of over a million homes. The maximum shortage was at the end of 1921, when it reached at least one and a quarter million. Some responsible estimates placed it higher. Then the tide turned. Nineteen twenty-two held its own. Each year thereafter showed substantial gains. By 1926 the end of the shortage was in sight. By 1928 it had been reached. In a nation-wide numerical sense, there was 
no longer a housing shortage. We were back where we were before the War, with qualitative rather than quantitative needs. So far as net progress was concerned, ten years had been lost.

While the shortage lasted, standards were lowered instead of raised. Instead of landlords competing for tenants, tenants were competing for any sort of shelter. Rents soared, only checked here and there by legal restrictions. Repairs were neglected. Families doubled up. Single-family houses were divided into apartments. Large apartments were cut in two. Vacant houses, unfit for human habitation, were filled to capacity. Landlords who had been through lean years found their property a sudden gold mine. Many of them saw that this happy condition would not last and sold while the market was good. In most cases the purchaser was not seeking a permanent investment, but a speculative profit in rising values. He had no interest in spending money on repairs, but concentrated his attention on a quick sale. In New York, tenement houses changed hands two or three times a year. Neither tenant nor Tenement House Department had a chance to locate the new owner before he was gone. The Philadelphia experience has already been described (p. 38).

Overcrowding was reported everywhere. The inevitable results were noted, social as well as physical. In 1920, the Health Officer of Cleveland stated that illegitimate births had suddenly doubled in the city, and that he considered overcrowding the principal cause.

\section{In New York}

In 1919 Governor Smith of New York appointed a Housing Committee as part of a Reconstruction Commission. The veteran Dr. Felix Adler was a member, 
and a young architect on the editorial staff of the Journal of the American Institute of Architects, Clarence S. Stein, who had already shown an enlightened interest in housing, served as its volunteer secretary. In March, 1920, it presented its report. A number of civic organizations had coöperated in making the survey.

"The survey disclosed that families were crowded together in dark, ill-smelling apartments and were unable to find better quarters. Many landlords weı taking no care of their apartments. Underpaid janitors neglected their duties. In some cases, there were no janitors, and the stairs were never cleaned except by the tenants. In every block were found ill-kept apartments, in fact, certain of them were not kept at all. They had been allowed to fall into decay. The roof leaked, the plaster was falling off the wall and the stairs needed repair. The water did not run, the landlord refused to repaper or paint the dirty walls. The rubbish collected in the basements. Yet every apartment was full and the tenants were afraid to complain to the landlord for fear he would dispossess them. One tenant said that her shoes had been worn out looking for another apartment, but she had found nothing but 'rat holes' " (Report of the Housing Committee of the Reconstruction Commission of the State of New York, March 26, 1920, p. 21).

In 1914, 20,577 new apartments (family units) had been built in New York City; in 1915, 23,617; in 1916, 21,359 . In 1917, the number fell to 14,241 , in 1918 to 2,706, and in 1919 to 1,481. Assuming only normal rate of increase of population, the shortage in 1920 would be some 40,000 apartments, the Housing Committee reported.

In 1919, the Legislature of New York also appointed a committee to investigate housing conditions in the 
state, which came to be known by the name of its chairman as the Lockwood Committee. A special session of the Legislature in June 1919 carried out several recommendations of this committee. Resolutions were passed urging the New York delegation in Congress to work for a Federal Home Loan bill and to exempt from federal taxation the bonds of the Land Bank of the State of New York. They amended the Tenement House Law to facilitate the conversion of single family houses into apartments. They amended the state banking laws to permit savings banks to make building loans. They passed an act requiring landlords to give monthly tenants twenty days dispossess notice instead of ten, and another authorizing the judges of the municipal court of the City of New York to grant stays of execution in dispossess cases of twenty days instead of five, where the tenant deposited rent at the old rate with the clerk of the court. Further steps in this direction will be described in the next chapter.

It is of interest to note, in the Preliminary Report of the Lockwood Committee (1920), the statement that if the worst of the old-law tenements in New York were not modernized by the owners, "action on the part of the city or state will become necessary", and later that "the question of state and municipal aid has been submitted to the Attorney-General for opinion as to constitutionality."

A report to Governor Smith by the Commission of Housing and Regional Planning in December 1923 indicated that there was still no relief as to housing shortage. Two years later marked improvement was recorded, but not yet a normal condition. The annual vacancy surveys of the Tenement House Department tell the story, perhaps, most concisely.

In 1909, following a period of over-building, there 
were $8.08 \%$ of vacancies in New York apartments. In 1916, there were $5.60 \%$, which is about normal to permit freedom of choice on the tenant's part. In 1917, this had dropped to 3.66, in 1919 to 2.08 and in 1920 to .36. And all of the vacancies in this fraction of one per cent were at rentals of $\$ 50$ per month or more. This condition persisted for five terrible years. In January 1921 vacancies were $.15 \%$, in $1923, .37$, in $1924, .83$. But January 1925 showed 2.23\%, January 19263.46 , January 19275.15 (normal again), January 19286.63 and January 1929 7.76, which is distinctly more than normal. In old-law tenements (those built before 1901) the vacancies were $9.32 \%$ in 1929 . According to the estimate of the State Board of Housing in its March 6,1929 , report, the rate of vacancies on the Lower East Side was at that time about $17 \%$. According to the September 1930 issue of Housing, the Tenement House Department placed it at $221 / 2 \%$ on January 1, 1930. This great stream of migration from the Lower East Side is one of the most encouraging things that has occurred. The 1930 Census shows a reduction in its population of 232,420 people, or about $40 \%$, in the decade since 1920.

\section{In Philadelphia}

The annual reports and special studies of the Philadelphia Housing Association show a similar series of figures. The housing shortage on January 1, 1921, was estimated at 19,600. In April 1923 there were only 412 vacancies among 61,133 houses in 14 industrial areas which were canvassed by the Association. This was .67 of one percent. Yet even these vacancies when looked into, proved to be mostly for sale only, or unfit for occupancy, or under repair. By January 1, 1925, the net 
gain had been some 2000 dwellings, leaving the shortage still about 17,600. In April 1925, a survey of 63,118 dwellings in 15 industrial districts revealed 789 vacancies, or $1.25 \%$. But of these, less than half were available for rent under $\$ 50$.

From page 17 of the 1927 report (published in 1928) we take the following table:

New Dwelling Construction-1921-1927, Inclusive.

Total number of housing accommodations provided

1921 to Dec. 31, 1927

By new construction

By legal conversion of dwellings

Total number of housing accommodations needed

1921 to Dec. 31, 1927

To care for normal population increase

To care for families dehoused by demolition

\section{The Building Cycle}

A similar story could be told in most parts of the country. But there is another lesson to be learned from nation-wide building permit figures for 257 cities of 25,000 inhabitants and over, as reported in the Monthly Labor Review (May, 1930, p. 137).

$\begin{array}{lc}\text { Year } & \text { Number of families provided for } \\ 1921 & 224,545 \\ 1922 & 377,305 \\ 1923 & 453,673 \\ 1924 & 442,919 \\ 1925 & 491,222 \\ 1926 & 462,214 \\ 1927 & 406,095 \\ 1928 & 388,678 \\ 1929 & 244,197\end{array}$

This shows the workings of the supply and demand residential building cycle. It started with a shortage 
which spurred building to additional volume, reaching its maximum in 1925 . The shortage vanished and with it effective demand except for replacements and population increase. The 1929 volume of residential building had almost reached the low level of 1921 . Nor was that the end. The first half of 1930 provided for only 52,489 families against 142,066 during the first half of 1929-a falling off of $63.1 \%$. And 1929 was producing less than half of 1925 . The aggregate cost of the 1930 housing as compared with 1929 fell off $72.7 \%$. Non-residential building fell off too, but not so much-25.9\% in the matter of aggregate cost, or for both classes of building 53.1\% (Monthly Labor Review, August, 1930).

There is no reason to suppose that so long as our home building depends wholly on private business enterprise acting under the law of supply and (effective) demand, we shall not have a series of cycles like the above, distinguished by a shortage followed by a building boom, then a surplus followed by a building slump. Has this factor been sufficiently considered in discussing business cycles? Isn't building after all a key industry? A fairly reliable index to prosperity? To what extent, then, is the drop in residential building, which was inevitable as soon as the housing shortage was overcome, a cause - even a major cause-of our present business depression? If a non-commercial, but economically sound method can be devised to build for the subnormally housed millions during the periods when effective demand for housing on a commercial basis is slack, so that the building trades will be uniformly busy, shall we not have taken a considerable step toward eliminating the periodic business depression ${ }^{1}$

${ }^{1}$ In September, 1921, as chairman of the Committee on Housing of the American Association of University Women, the writer addressed an open letter to Secretary of Commerce Herbert Hoover, who had 


\section{In European Countries}

The post-war housing shortage was far from being an exclusively American phenomenon. European belligerents suffered from it more acutely because for them the war-time halt in building lasted four full years. In addition, for those nations which furnished the battlefields, whether on the western, southern or eastern fronts, there were hundred of thousands of destroyed houses to be replaced. Even the neutrals were seriously affected by rising building costs and in some cases by inability to import essential building materials.

A convenient general survey of the European situation in this respect, is found in a volume issued by the

been appointed Chairman of a Conference on Unemployment, from which the following extracts are taken: " ... All sorts of suggestions ... will be urged upon you. The Government will be asked to undertake a variety of public works-roads, irrigation, river and harbor improvements or public buildings-in order to afford employment and relieve distress. .... Clearly no Government can let its people starve, yet a more unpropitious time for embarking on great public expenditures which will ... increase the already heavy burden of taxation-can hardly be conceived. . . There is a way, however, Mr. Secretary, in which large-scale, varied and widely distributed employment can be afforded without adding one cent to the tax payer's burden, - a way which, if adopted, would also solve one of our most vexatious domestic problems and thereby raise the standard of health, happiness, family life and good citizenship among our people. We are short at least a million and a quarter homes in the United States today. Commercial business enterprise is not providing them. ... We do not suggest any plan involving government subsidy.... We suggest-and we urge-a great nation-wide program of home-building, under government auspices, on a strictly at-cost basis, whatever that cost may prove to be. And we mean at-cost all the way back. We mean that the organization to be formed should make its own bricks, mix its own concrete, saw its own lumber. ... Homes so built could be sold to would-be home-owners, payments extending over a term of years, on a basis of price and interest exactly calculated to cover the principal and interest of the bonds which had been issued to finance the enterprise.". This proposal received some friendly comments, but was never seriously considered. If the proposal were being formulated to meet 1931 conditions, the writer would substitute state for national auspices and add safe-guards to limit home purchasers to the lower income groups. 
International Labor Office at Geneva, "European Housing Problems Since the War, 1914-1923." Statistics tell the story. Building operations slackened and died. Vacancies dwindled to zero. Lists of families forced to double up and applying for separate accommodations grew to an alarming extent. Consciousness of shortage became acute in belligerent countries in connection with demobilization. The table opposite is reduced in size from page 12 .

Efforts were made in the various countries, following the war to estimate the extent of the housing shortage. An official commission reported Great Britain short about a million family units, though the accuracy of this figure was questioned from both directions. German estimates ran to one and a half million. Official estimates in Belgium varied from 90,000 to 240,000 . It was subsequently found that war destruction alone ran approximately to the former figure. Holland had a national housing census taken which showed a shortage of 164,000 dwellings.

On a per capita basis, it will be seen that the shortage in Great Britain, Germany and Holland was of about the same intensity and that it was roughly twice as bad as ours at its worst. France, Belgium, Italy, Poland, Serbia, and other war-devastated countries were much worse off.

Measures of dealing with the housing shortage strikingly similar in principle, though differing widely in detail and in extent, were adopted by almost every European country during the year 1919. These measures took the form of special emergency legislation for a government housing program on a subsidized basis, since only on that basis could new houses at their postwar cost, be rented low enough to meet the needs of the bulk of the population. It is noteworthy that they did 


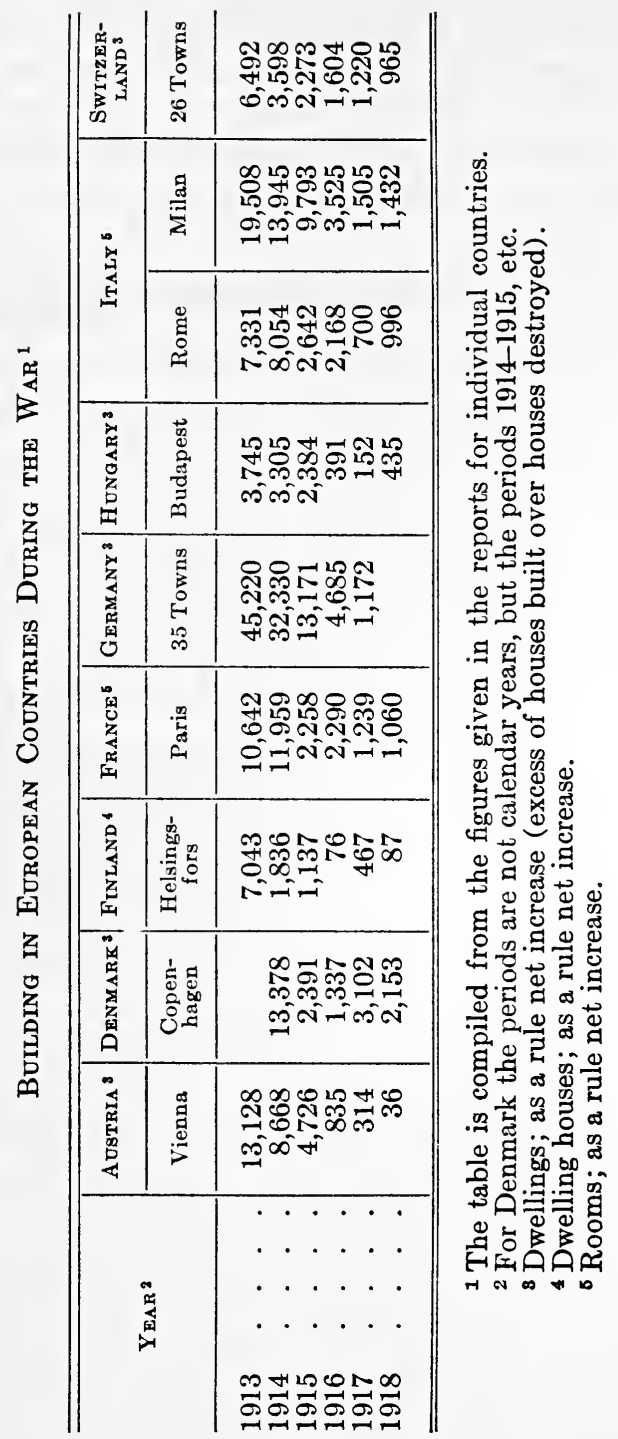


not lower standards to meet needs, nor did they to any appreciable extent resort to temporary construction. Neither did they produce houses for the well-to-do, hoping that their vacated quarters would eventually bes:efit the overcrowded masses below. The subsidy feature, abundantly grumbled about, was accepted as part of the cost of the War.

The fact that we did not in this country adopt an analogous program is partly due, no doubt, to our relatively less acute situation, but more to our physical distance, which greatly lessened the force of example, and to our less developed state of public opinion on the whole subject of housing. The few scattering attempts in this country to adopt European methods of dealing with the housing shortage were neither wisely planned nor strongly supported and were either total failures or not far from it, as will be discussed later. 


\section{CHAPTER III}

\section{RENT RESTRICTION}

RENT restriction is a war baby. Without the War, it could hardly have gained a foot-hold either in Europe or America. It represents the most radical interference with the rights of private property of any housing measure adopted outside of Soviet Russia, and it probably has the least permanent value. Before the War, it existed only in the very mild form of the Fair Rent Courts of Australia, where little beside moral suasion was used, and that only in flagrant cases. Yet that used to be referred to as "state socialism" in the orthodox economic discussions of the day.

The War, however, soon forced much more stringent measures. Long before the shortage due to the stopping of building was felt, there was a shortage due to suddenly expanding population in national capitals and other centers of war activity. Hence a prompt tendency for rents to rise. At the same time a large part of the productive manhood of each nation were mobilized with the colors. Wives and children, left behind with greatly diminished income, could not possibly meet increased rent. They often could not pay the old rent. And so, in a few months time, in nation after nation, laws were passed to keep rents at the 1914 level and to prevent eviction as long as the old rents were paid. As a rule, soldiers' and sailors' families were protected, rent or no rent. Neutral countries were affected later and less intensely, but by the end of the War nearly the whole 
of Europe was covered by some form of tenant protection. ("European Housing Problems since the War," Part I, Chap. 2.)

Rent restriction was logically followed in some, but not in all countries, by a greater or less control of housing accommodation, including the requisitioning of unoccupied dwellings or parts of dwellings (Ibid., Chap. 3). This tendency reached its full development only in Soviet Russia, but was conspicuous also in post-war Germany and Austria. Its extremely mild use in a few American cities has been mentioned in Chapter I.

As the writer has said more than once, rent restriction is like a dose of morphine, necessary sometimes in emergency to ease excessive pain, but having no curative value, having, indeed, a tendency to aggravate the causes which produce the pain.

Permanent rent control is logical where and in so far as housing is a public utility - a function of government. Where and in so far as housing is a commercial service dependent on private business initiative, it is clearly illogical if not suicidal. The whole theory of supply and demand requires that they be allowed free play. Scarcity raises prices till they stimulate production. Production continues briskly till prices fall. Production then slackens till scarcity causes prices to rise again, and the cycle is repeated. Artificial checking of the rise of rents throws the whole process out of gear.

Rent restriction may be necessary in an emergency, but we should understand what we are doing when we resort to it and what the effects will be.

One inevitable effect will be to check residential building,- the only process which can relieve the shortage which induced the higher rents. Exempting new dwellings from rent restriction does not obviate this, as confidence in this form of investment has been destroyed 
and every one knows that the power which created a rent restriction law can enlarge its scope.

Another effect is that rent restriction, once started, as in the case of other habit-forming drugs, is extremely difficult to leave off. Sudden stopping at any given moment would involve a great deal of hardship. Moreover, people do not like to give up privileges they have once acquired-whether they be landlords or tenants. There are a great many more tenants than landlords, and they have a great many more votes. Few legislative bodies hold out against them when organized and sufficiently clamorous. So we see date after date set for the end of rent restriction, and as often we see that date postponed.

Sweden ended hers in 1925 and got away with it at the cost of erecting temporary municipally owned quarters for evicted tenants. Her problem then became how to do away with the temporary quarters. Italy ended her rent restrictions in 1926 , but almost immediately reestablished them in effect, though not in name, the final control being decidedly more drastic than the first, as recalcitrant landlords may now be sent into enforced exile. Great Britain permitted an increase of $40 \%$ in rents in 1919 and has been raising the bars gradually since. De-control was to have been complete in 1927, but five years were added to make the process more gradual. Belgian rent control was to end in 1930 and that of France in 1931.

Post-war Vienna, under a Socialist city government, has pursued the most radical course outside of Russia. The landlord's share of rent on pre-war houses has been limited to a purely theoretical return on his investment -i.e., half the rent he received in 1914. But as this sum has not been readjusted with the enormous fluctuations of Austrian currency, it has been, for all practical purposes, wiped out. A thousand 1914 Austrian kroner 
are worth but a few cents today. In partial compensation, ground taxes, repairs and all maintenance costs are borne by the tenant, who pays, in addition, a steeply graduated dwelling tax (Wohnbausteur), out of which the municipal housing program is financed on a cash basis without resort to loans. If the tenant fails to pay taxes or to make repairs, however, the owner is held responsible. If he cannot make good, the property is sold at auction and bought in by the city (there being few competitors), which is thus gradually becoming the one great landlord.

The German system of handling the situation has been much less radical than that of Vienna, but considerably more so than that of her neighbors to the North and West. It is worth noting that the three most radical invasions of property rights in connection with housing have occurred, not among the previously democratic nations of Europe, but in the three countries which had been most completely under systems of autocratic suppression. Moreover, the distance and violence of the pendulum's swing to the left has been in direct proportion to the previous completeness of reactionary control. To those interested in conserving what appears to them to be of value in the existing order of things, this might seem to indicate the practical advantage of palliative measures as safety valves to prevent boiler explosions, quite aside from considerations of humanity or social justice.

To us in the United States also, rent restriction came with the War. We did not stop to experiment or to discuss. We took over European methods. Had we not accepted conscription and food regulation and given up freedom of speech? Rent restriction was a mere detail. Yet of course the constitution did bar national legislation on the subject. Some of our states protected all 
tenants, others took action only in favor of families of men serving in the army or navy. Specific legislation of this sort was enacted by Maine, Massachusetts, Connecticut, New Jersey, Virginia and Nevada. ${ }^{1}$ Congress passed the Soldiers' and Sailors' Relief Act in 1918 and also the Saulsbury Resolution, which was followed by the Ball Rent Law in 1919, applying to all rents in the District of Columbia.

New London, Conn., in the days of war industries and housing shortage, appointed a Committee of TwentyFour, representing employers, employees, lawyers and real estate men. It was divided into groups called adjustment boards, which heard complaints and determined fair rents. If the landlord refused to appear, that fact was published. This method was sponsored by the Bureau of Industrial Housing of the Federal Department of Labor. It was copied in seventy-six other towns with war industry housing problems (Page 14, Report U. S. Housing Corporation, Dec. 3, 1918).

Municipal committees functioned with varying success in Fresno, Los Angeles, Jersey City, Atlanta, Chicago, Wichita, Baltimore, Newark, Buffalo, Cleveland, Dayton, Akron, Philadelphia, Seattle, Portland, Ore., Boston and Milwaukee, to name only a few. Some held authority under state law, some by city ordinance. Others had nothing behind them but war need and could inflict no penalty but publicity.

Most of this came to an end with the War. Exceptions were the District of Columbia, New York State, New Jersey and Massachusetts. Wisconsin was also an exception, until the courts pronounced her rent law unconstitutional.

${ }^{1}$ A good résumé of this American experience is given in "The Public Control of House Rents," by Marcus Whitman in the Journal of Land and Public Utility Economics, for July, 1925. 


\section{The District of Columbia}

The War had expanded Washington almost overnight from a city of 300,000 to one of half a million, most of the new-comers being low-paid government clerks. Washington had been a city of one and two-family houses at low rentals, with a considerable margin of vacancies. Apartment house construction was still in its infancy. The United States Housing Corporation built hotels for approximately 2000 women clerks in the vicinity of the Capitol and Union Station ${ }^{2}$ and dormitories for nearly 500 men workers at the Navy Yard. Its further housing program was abandoned after the Armistice. The Bureau of Industrial Housing had a Homes Registration service and its right of requisition. But something more was needed to curb post-war profiteering by landlords. Hence the Rent Law already mentioned.

The Rent Commission in Washington, established by the rent law, was composed of five members. ${ }^{3}$ When either the tenant or the landlord was dissatisfied with an existing rent, he appealed to the Commission to revise it. Both parties were heard and the premises visited. The Commission determined the fair value of the house largely by deducting depreciation from replacement value and by considering critically the landlord's list of annual expenses. The rent was set sufficiently above

${ }^{2}$ Six of the original twelve temporary structures have been demolished to make way for government buildings. Such strenuous protests from the occupants have met every suggestion of tearing down the rest that they have so far been permitted to remain in service. They are efficiently managed, meet a real need, and cost the tax-payers nothing, as they are self-supporting.

${ }^{3} \mathrm{An}$ account of its origin and procedure is found in an address by one of its members, Clara Sears Taylor, before the National Housing Association in its 1923 Conference, "Housing Problems in America," Vol. IX, pp. 191-201. 
the sum of these expenses to give him a net return of 6 to $10 \%$ on the fair value as above defined. Marcus Whitman thinks that the Washington Commission tended to fix rents nearer the lower limit.

In May 1925, the District of Columbia Rent Act came to an end. A strong effort had been made to renew it for five years. So conservative a thinker as President Coolidge endorsed the measure. But the arguments of the real estate groups ultimately prevailed with Congress. In an effort to meet individual cases of hardship, the Real Estate Board established a committee of its own to consider reported abuses on the part of the landlords.

\section{Massachusetts}

Emergency rent laws were enacted in Massachusetts in 1919 and 1920. They were to have expired in 1923, but were continued till 1925, then to 1926 and to 1927 . Thirty days' notice of eviction was required and cases could be heard by the Massachusetts Special Commission on the Necessaries of Life or by the local rent and housing committee established by it. By January 1923, the Commission had handled over 50,000 landlord-andtenant disputes, while the Boston Committee had heard over 26,000. A $25 \%$ increase in rent was held to be unreasonable unless the landlord could definitely prove the contrary.

\section{New York State and City}

The first step toward protecting tenants in New York City from summary eviction was taken in 1919, as stated in the last chapter, on recommendation of the Lockwood Committee. It amounted only to 20 days' notice and authority to the court to grant a 20 days' stay of execu- 
tion and proved a wholly ineffective barrier against the rising flood of dispossess notices. Additional legislation secured in April 1920 still failed to meet the need. October 1, 1920 was the date on which, delays and stays being exhausted, tens of thousands of these notices were due to be executed. The situation constituted a very real crisis. There would be no place for the evicted tenants to go. They were desperate. Riot and bloodshed were feared. An army of men, women and children could not be expected to camp on the side-walks through a New York winter.

Governor Smith called a special session of the legislature in September to deal with the housing crisis. Six months earlier the Governor's Housing Committee, mentioned in the last chapter, had sent in its report dealing with the causes of the temporary housing shoriage and of the permanent housing problem. They recommended a long-range program including the establishment of local and state housing and planning boards for fact-finding and policy forming purposes, an amendment to the state constitution permitting state housing credits at low interest rates to reduce the cost of new housing by limited dividend companies, a policy of city ownership of undeveloped land in the out-skirts to control the price of building sites, and a policy of municipal building if and when all other methods failed.

These far-reaching measures, however, held little immediate interest for the panic-stricken tenants. Trainloads of them traveled to Albany and thronged the legislative hearings. They shouted and shook their fists. A few wept. The landlords were there too, but there were not so many of them, and their voices were drowned out. So, in spite of the Governor's indorsement, the legislature paid no attention to the Housing Committee's recommendations. It enacted, however, 
a rather efficient group of emergency rent laws, forbidding evictions so long as the tenant paid the former rent, unless he could be proved to the satisfaction of the court to be definitely objectionable, or the landlord could prove that he needed the premises for his personal use as a home, or unless he wanted to demolish them in order to rebuild and his plans had been approved by the proper authorities, or unless he had sold out in good faith to a bona fide coöperative company. Even where the tenant had agreed to an increase in rent, if he claimed the agreement was made under duress, the additional amount could not be collected unless the owner brought action and the court pronounced that the increase was justified. The owner had to base his claim on full particulars as to income and expenses as well as value of the premises. The court calculated a fair return on the whole value of the property, not simply the owner's equity, as otherwise there would have been great variations in the rentals of similar properties. New York judges put a "fair return" somewhere between 6 and $10 \%$, usually around 8 .

These rent laws at first applied only to cities of one million inhabitants and over (New York) and to cities in adjoining counties (Yonkers and a few other communities in Westchester County and on Long Island). Buffalo and Rochester were subsequently included, and in the spring of 1923 Albany and nearby towns were added-Schenectady, Amsterdam, Troy, Cohoes, Watervliet and Rensselaer. The rent laws did not apply to new dwellings or to hotels or transient lodging houses. Their protection was lost to the tenant who moved. They were originally enacted for two years only (till November, 1922), but were re-enacted for another two years on the ground that the emergency continued. When again re-enacted in 1924, Rochester was exempted 
from their jurisdiction. In 1926, they were continued on until June 1, 1927, with the provisions that the law should no longer apply to dwellings or apartments in New York City which were renting at $\$ 20$ or more per room per month on December 31,1925, or to those in Buffalo and Albany renting at $\$ 15$ or more.

In 1927, on recommendation of the newly established State Board of Housing, the rent laws were continued until June 1, 1928 for dwellings and apartments renting at not more than $\$ 15$ per room per month in New York City or $\$ 7$ in Buffalo.

In its report to the Governor of February 25, 1928, the State Board of Housing found that the emergency which had been the reason for the rent laws had ceased to exist and recommended their discontinuance on the date set. They recommended permanent legislation which would give the courts power to grant a six months' stay in holdover proceedings to meet cases of real hardship. This has since been secured. A normal number of vacancies now existed due to intensive building over a period of years. The Board admitted that about 193,000 families would be adversely affected by the ending of the rent laws, of whom about 167,000 were paying less than $\$ 8$ per month per room. The Governor endorsed the recommendation of the Board. Hereupon occurred a rather amusing display of human nature. The tenant organizations took the matter up energetically with their representatives in the Legislature. The situation was by no means as tense as in 1920, but sufficiently so to produce results. The strongly Republican Legislature, which had opposed Governor Smith's housing policies as "radical," "socialistic," and what not, now became intensely responsive to the sufferings of tenants and, with righteous indignation over the proposed termination of the rent laws, continued them for 
another year, providing only that dwellings in New York City renting at more than $\$ 10$ per room per month should be exempt after December 31, 1928.

The 1929 Legislature got its courage up to permitting the rent laws to lapse. Whereupon the Board of Aldermen stepped into the breech, passing an ordinance to continue rent control in New York City for still another year. The courts, however, decided that they lacked jurisdiction.

In addition to its bevy of rent restriction acts, ${ }^{4}$ the 1920 Special Session of the Legislature passed a permissive tax exemption act, which had the support of builders. This will be discussed in the next chapter.

${ }^{4}$ The Emergency Rent Laws may be consulted in the Statutes of 1920 (regular session), Chapters 130, 131, 132, 133, 134, 135, 136, 137, $138,139,209,210$, and (extraordinary session) Chapters 942, 943, 944, 945, 947, 948, 949, 950, 951, 952, 953. Also Statutes of 1921, Chapter $165,298,367,371,374,434$; Statutes of 1922, Chapters 281, 658, 663, 664 ; Statutes of 1923, Chapters 278, 892.

Valuable data on the housing shortage and the rent laws in New York State are found in the reports of the Commission of Housing and Regional Planning of Dec. 23, 1923 and Dec. 23, 1925, and in those of the State Board of Housing of March 9, 1927 and Feb. 25, 1928. Neither body favored rent restriction theoretically, but both accepted it as a temporary necessity. A strong statement of the case against rent restriction was made by Professor Samuel McCune Lindsay of Columbia University in the pamphlet, "Some Economic Aspects of the Recent Emergency Housing Legislation in New York," printed for the Law Commitee of the Real Estate Board of New York, Oct. 1923, revised and reprinted Feb. 1924. 


\section{CHAPTER IV}

\section{TAX EXEMPTION}

Subsidy, in some form, is the almost necessary corollary of rent restriction. In New York, it took the form of tax exemption, which, whatever may be said to the contrary, is essentially a subsidy. It may be beneficial in some cases. It may, at times, be almost a necessity. But, as in the case of rent restriction, the public should understand clearly what it is. To balk at non-subsidy public credits as economically unsound and adopt tax exemption is sheer muddle-headedness.

Rent restriction, having violently arrested the action of supply and demand by checking the rise in cost due to scarcity, it became necessary to stimulate building artificially by the offer of a bonus at the tax-payer's expense. In a number of European countries since the war, this has taken the form of open subsidy. ${ }^{1}$ In New York since the War and in certain European countries before and since, ${ }^{2}$ it has been partially camouflaged as tax exemption. In all European cases, however, either

${ }^{1}$ Neville Chamberlain, Minister of Health in the last Conservative cabinet and author of the British Housing Act of 1923, the distinctive feature of which is encouragement of small home building by the payment of a flat subsidy to the builder, said he had preferred that method to tax exemption, because tax exemption was the most dangerous form of subsidy - a concealed subsidy.

${ }^{2}$ For cases of pre-war tax exemption, see Bulletin 158, Bureau of Labor Statistics, "Government Aid to Home Owning and Housing of Working People in Foreign Countries." For post-war cases, "European Housing Problems since the War," previously cited. 
of tax exemption or open housing subsidy, the legislation was enacted for a definitely social purpose, and the social benefit was conserved by retaining control over (1) the standard of house built, and (2) the rent or sales price. It remained for New York to provide tax exemption with no requirement as to standard beyond those which apply to all new dwellings and without the faintest attempt to limit rent or selling price. Thus applied, tax exemption becomes a subsidy to the building industry rather than to health and welfare. ${ }^{3}$

Due to intensive work by a few individuals and civic bodies, New York City, in adopting the permissive tax exemption law enacted by the Legislature, limited the exemption to $\$ 5000$ on a single-family house, $\$ 10,000$ on a two-family house, and $\$ 1000$ per room, with a maximum of $\$ 5000$ per family unit, on an apartment house. This did, of course, so far as it went, have a socially useful effect by favoring the erection of inexpensive houses and apartments.

New Jersey passed a tax exemption law containing no restrictions whatever. It was probably fortunate that the courts declared it unconstitutional.

Bethlehem, Pa., in 1923, adopted an ordinance granting five years' tax exemption to residential buildings completed before July 1, 1929, on assessed valuation up to $\$ 7000$ per dwelling.

The New York State Law (Chap. 949 Acts of 1920) permitted a county, city, town or village to exempt from local taxation until January 1, 1932, under whatever restrictions might be locally adopted, all new dwellings, except hotels, begun before April 1, 1922, and completed within two years of that date. New York City was the only community to take advantage of the permission.

${ }^{3}$ For a discussion of tax exemption under the New York State Housing Law of 1926, see the end of this chapter. 
As its ordinance was not adopted until February 15, 1921, ten years was the maximum tax exemption period.

The time for starting building was first extended for a year-till April 1, 1923. The ordinance actually expired at that time, but three months later was re-enacted by the Board of Aldermen for another year, limiting its benefits on multiple dwellings to $\$ 15,000$ per building, thereby giving a useful impetus to the small as against the large apartment house. Limitations on one and two-family houses remained as before. ${ }^{4}$

In the spring of 1924, as the limit date again approached, the Commission of Housing and Regional Planning, frankly recognizing tax exemption as a subsidy, advised, never-the-less, that it be extended for a time provided its benefits were limited to "one and twofamily houses to be sold for a limited price and to apartments to be sold for co-operative ownership at a limited price or to apartments for which a limited rental will be charged." As this failed to appeal to speculative builders, tax exemption was allowed to lapse. During 1925 and 1926, however, large numbers of dwellings continued to be finished which were tax exempt because begun before April 1, 1924.

There is no doubt that tax exemption broke the postwar residential building deadlock in New York City and brought about great activity earlier than would otherwise have occurred. In 1921 the net increase in family units (apartment, single-family or two-family) was only 10,708 . In 1922 , it had increased to 48,935 , in 1923 to 64,145 , and in 1924 to the extraordinary num-

${ }^{4}$ Copies of the law and its amendments and of the City ordinances referring to it will be found in the appendices of the "Report of the Commission of Housing and Regional Planning," of March 14, 1924, which also gives a résumé of its results to that date. 
ber, 90,691 . How much of this was due to tax exemption and how much would have occurred anyhow, it is impossible to say. In 1925, due perhaps to the rush the year before to get started in time to be tax exempt, the number fell to 65,511, but it picked up in 1926, and in 1927, when tax exemption had ceased to be a factor, passed the 1924 record. This proved to be the peak. There was a drop in 1928 and a bigger one in 1929. The numerical shortage had been wiped out and a surplus established. Effective demand at existing price levels had been supplied. Between 1920 and 1929 there had been a net increase in family housing accommodations of 616,328 units, or about $46 \%$ of the previous total. (Report of the State Board of Housing, 1930, p. 54.) On the basis of population or of number of rooms, the percentage increase would be much less, for the new apartments run small and are seldom crowded.

The subsidy, for those who obtained the full ten years' exemption and were able to keep construction expenses within the exempt limits, amounted to one-third of the capital cost. (Report of the Commission of Housing and Regional Planning, March 14, 1924, p. 16.) Even those who did not build until 1924 received a benefit equal to about $22 \%$ of capital cost.

The rather rare individual who built his own home thus derived a substantial benefit. Where he purchased a home from a speculative builder, the latter got most of the profit. But the years of tax exemption, during which the second mortgage could be paid off, were what made the transaction look possible to many purchasers.

The effect on city revenues has received surprisingly little attention. It has been frequently said that to whatever extent tax exemption produced building which would not have occurred at all without it, the city reaps 
a deferred benefit at the end of the exemption period. ${ }^{5}$ To the extent that tax exemption hastened by one or two or half a dozen years, building which would have taken place later anyhow, the city sustained a direct loss, though indirect social benefits might-or might not -make up for it. To the extent that the city granted tax exemption to building which would have taken place when it did without it, it was obviously all loss.

In the 1924 report of the Commission of Housing and Regional Planning already referred to, the effect of tax exemption on city revenue was considered on the basis of figures then available (pp. 17-19). But the effects have been multiplied several times since that date. The 1929 report of the Commissioners of Taxes and Assessments (p. 12) gives the total amount of exempt valuation under the provisions of the Ordinance of February 15, 1921, as $\$ 916,330,075$-not far short of a billion dollars. The total assessed valuation of New York City real estate in 1929 was $\$ 17,705,161,490$ (Ibid, p. 11). The amount of exempt property is not only a staggering figure in itself, but it represents a substantial proportion of total valuation. The added burden to tax-payers of providing police, fire protection, health, schools, and all the other services for this dead-head real estate during a term of years has been far from insignificant

In order to ascertain what the exempted taxes have amounted to, the writer secured the basic figures from the Tax Commissioner's department-exemptions and the tax rates in each borough for each year since ex-

${ }^{5}$ Another point made is that a substantial proportion of the small houses built in Queens, at least, are beyond the present limit of city improvements. Having neither sewers, pavements nor schools, it would have been hardly just to tax them for services they did not receive. On the other hand, it is one of the dark features of the situation that assessments for these improvements, when they come, will cause many of the installment purchasers to lose their homes. 
emption started, to and including 1930. The staff of the State Board of Housing kindly made the computations. The result deserves study. The exempted taxes add up to $\$ 167,066,888.24$. Assuming that 1931 will have about the same valuations and tax rate as 1930 (they have varied little since 1926), we may estimate that when the exemption period ends, the beneficiaries will have received from the tax-payers a subsidy of approximately $\$ 191,387,000$.

In other words, post-war housing in New York has been as truly and as heavily subsidized by the taxpayers as post-war housing in London or Liverpool or Manchester. The big difference has been that in the English cities the subsidy enabled families of the lower income brackets to live in very high grade new houses, whereas in NewYork the subsidy made gorgeous profits for the builders, but the houses were very ordinary, ${ }^{6}$ and even so, only those of higher income could live in them.

Rents in the new buildings, unaffected by rent restriction laws, soared happily. Nearly half the new suites built in 1924 rented for $\$ 20$ per room per month and up. About $17 \%$ rented for $\$ 15$ per room per month or less. The rest were in between. Queens had the lowest rents and Manhattan the highest. Rents were lower in Brooklyn than in the Bronx. In Manhattan over $92 \%$ of the new apartments rented at $\$ 20$ per room per month and up, over $60 \%$ at $\$ 25$ or more and nearly $42 \%$ at $\$ 30$ or higher (Report of the Commission of Housing and Regional Planning, Dec. 23, 1925, p. 21). The newspapers carried advertisements indicating that those who invested in the new apartment houses could recover their capital in three years. Probably they could not, but the suggestion portrays a mental attitude.

${ }^{6}$ The flimsy frame houses of Queens are worse than ordinary and constitute a gigantic fire risk. 
It has been the income groups between $\$ 2000$ and $\$ 3000$ who especially suffer from these rents, though many of higher income pay a disproportionate amount of it to secure adequate housing. In general only the top economic third have found their way into the new houses. Those below have had to content themselves with the relief resulting from lessened pressure from above.

It was in the hope of carrying the benefits of tax exemption to lower income levels and at the same time insuring higher standards, that the Commission of Housing and Regional Planning recommended that if it were continued for dwellings begun later than 1924, it should be granted only, in effect, to limited dividend or cooperative companies. It was in this form that the project was revived in 1926.

In that year, the Commission prepared a bill, sent to the Legislature by Governor Smith with his strongest endorsement, to create a State Housing Loan Bank and a State Board of Housing, able, among other advantages, to grant state tax exemption to approved limiteddividend housing companies, and permitting cities to exempt such companies from local taxes. The bank was cut out by the Legislature, but most of the other features survived in the important State Housing Law of 1926.

A year later, the city of New York passed an ordinance granting twenty years' tax exemption on buildings constructed by limited dividend companies approved by the State Housing Board. The land was not exempted. This has been found in practice to reduce the carrying charges about $\$ 2.00$ per month per room in the coöperative and limited dividend companies which have been the beneficiaries. Under these conditions, it becomes a subsidy with a social purpose like those of Europe. 
The highly significant results will be discussed in a later chapter.

A person with a logical mind might prefer to see the benefit conferred by state or city credits without subsidy (loans furnished at the price of state or city bonds, approximately $41 / 4 \%$ ), but if American psychology ${ }^{7}$ accepts tax exemption and shies away from public loans, by all means let us have tax exemption, provided only it be of the 1926 rather than the 1920 variety. The one thing certain is that if we want fit citizens tomorrow, we must open the door to fit homes for the children of today.

${ }^{7}$ It may or may not have significance for us that tax exemption abroad for housing purposes is less in evidence today than it was twenty years ago, and much less in evidence in such countries as Holland and Great Britain than in such as Spain and Rumania. It may, perhaps, represent a stage through which nations tend to pass before public opinion in regard to housing becomes really discriminating. 


\section{CHAPTER V}

\section{TENEMENT HOUSE AND HOUSING CODES (DWELLING LAWS)}

In the last four chapters, we have been concerned with conditions and activities directly or indirectly growing out of the World War. It is now time to take up the pre-war threads. It will be recalled (Introduction, Sec. 4) that regulatory efforts in the United States at that period largely took the form of Tenement House or (restrictive) Housing Codes, local or state-wide.

The encouragement, drafting, enactment and enforcement of these codes were the special interest of the Veiller school of thought and therefore of the National Housing Association. The movement, however, appears to have reached its high point before the post-war period was fairly started.

The State of Michigan and the City of Minneapolis adopted the Veiller Model Law ${ }^{1}$ in 1917. (See "The Housing of the Unskilled Wage Earner," pp. 82, 88, 89.) St. Paul enacted a similar code the following year. In 1919 there were bills for state-wide housing laws of the Veiller type before the legislatures of Iowa, Illinois and Pennsylvania, while the Massachusetts legislature was considering a special housing code for Boston. All had good civic backing. Of them all, only the first went through successfully. The Iowa law, like that of Michigan, is an almost verbatim transcript of the Veiller

1 "A Model Housing Law," Lawrence Veiller, published by the Russell Sage Foundation, 1914 and 1920. 
model draft, and has proved its usefulness. The other bills, re-introduced in several subsequent years, were finally abandoned. A revision of the California State Act in 1919 was mostly downward. The Kentucky Act, applying only to Louisville and never very adequate, was suddenly repealed in 1922 at a moment when the reformers were napping.

Portland, Oregon, adopted a housing code on the Veiller model in 1919, but permitted it to be revised to please her real estate men during the following year to an extent that amounted to a repeal. Seven years later, a revival of interest in the subject caused the Mayor to appoint a Citizens' Commission to study the housing situation and recommend changes in the law. By the spring of 1930, they had drafted a code, still strangely weak for a progressive city like Portland as to yard and court requirements, but at least calculated to end the two most vicious features of the 1920 revision,- -an Advisory Board with power to waive requirements in special cases, and the general power to make exceptions by special ordinance.

During the last decade, not a single restrictive housing law, state or local, has been enacted in the United States. Yet restrictive legislation was the principal method of housing progress used in this country before the War.

The situation is not so discouraging as this statement and the preceding summary would, at first sight, seem to indicate, for many of the light and air provisions affecting new dwellings, which would formerly have been secured only through a tenement house or restrictive housing code, are now embodied in zoning ordinances. There are both advantages and disadvantages in this change, as will be more fully discussed in the next chapter. 
For the benefit of those not familiar with the Model Housing Law, it may be worth while to summarize very briefly what it does for the State of Iowa. It applies there only to cities of 15,000 inhabitants and over and is administered by local health departments, except for the fire provisions, which are under the building departments. The State Board of Health, which includes a State Housing Commissioner, has general supervision of enforcement should local authorities fail. It may also apply the code provisions, so far as applicable, to any mining camp in any township where conditions constitute a menace to health.

Provisions affecting dwellings hereafter erected insure a fairly high standard of light and ventilation for every room and hall, modern plumbing, city water and sewer connections wherever obtainable, and reasonable fire protection. Light and air are required to be let into old homes as far as practicable and sewer-connected sinks and toilets installed. Cellar rooms (more than half underground) are not to be lived in, and basement rooms (at least half above ground) must be dry, well lighted and well ventilated. Periodic inspection of all dwellings must take place at least once a year. Repairs and cleanliness are required and overcrowding is forbidden.

This statute has been decidedly useful to Iowa, but ought to apply also to smaller communities and to rural districts. This is well set forth in Bulletin 17 of the Iowa Board of Health (April, May, June, 1921).

\section{New York Multiple Dwelling Law}

The most important revision of an existing code is the recent action by the state legislature on behalf of New York City. It will be recalled that between its 


\section{Tenement House and Housing Codes}

first enactment in 1867 and its revision in 1901, the New York Tenement House Law was made over three times on the recommendation of a series of commissions appointed by the Governor, each time with notable gains won in the face of strong opposition. The 1901 revision had made a bigger advance than usual and had established the Tenement House Department with its large corps of inspectors as a uniquely efficient enforcing agency. It was natural that for the next few years reform groups should rest on their oars and occupy themselves with enforcement and with protecting their law from the annual flood of bills at Albany intended to weaken or repeal it. Unfortunately, however, this attitude became a habit.

The Hylan administration and the housing shortage proved an unhappy combination for efficient law enforcement. The shortage would inevitably have weakened standards under any administration, as even the worst of houses cannot be ordered vacated if there is literally nowhere for its tenants to go, and the landlord who does not wish to make repairs is not slow to find this out. The bad effect of rapidly changing ownership of tenements during the shortage has already been alluded to. But Mayor Hylan carried a grudge against the Tenement House Department during all the eight years he was in office. It was the one point where he practised economy, stripping the department as bare of employees as the city charter would permit. So greatly was its personnel reduced that periodic inspections had to be abandoned, although mandatory under the law. The situation has improved somewhat under Mayor Walker and Commissioner Deegan, and additional inspectors have been granted since the enactment of the Multiple Dwelling Law, but their numbers are still inadequate. 
The initiative to revise the 1901 Tenement House Law, when it did at last appear, came from the camp of its enemies. Hotel and apartment house owners had complained to the Mayor that the so-called apartment hotels were giving them unfair competition because they had been allowed to violate the Tenement House Law with impunity. The definition of a tenement house, it may be remembered, is one containing three or more families, living independently of each other, and doing their cooking upon the premises. By filing plans with the Building Commissioner as non-housekeeping apartment hotels, they had avoided the rigorous requirements of the Tenement House Law as to fire escapes and ventilation of bathrooms. While omitting kitchens, they provided serving pantries with sinks and running water and connections for gas or electric plates. All gradations of actual housekeeping followed from making an occasional cup of tea to cooking three meals a day for a family. Another numerous group of law violators were the owners of illegally converted houses, - single-family dwellings made over for the use of several families. Plans for these, in the same way, had been called non-housekeeping and filed with the Building Commissioner instead of the Tenement House Department. Sinks and gas plates were placed in clothes closets or corners of bed rooms.

The case was clear, and Mayor Walker ordered the Tenement House Department to stop all cooking in nonhousekeeping apartments or require the owners to make their buildings conform to the Tenement House Law. The apartment hotels owners promptly carried their troubles to Albany and demanded a revision of the Tenement House Law which would legalize their position. They were joined by groups which had always opposed the law. At this point the Tenement House Commit- 
tees of the Charity Organization Society and the Brooklyn Bureau of Charities thought they saw a chance for a step forward and added their voice to the request for a Commission to revise the Tenement House Law. The Governor must have been in sympathy with them, for the reformers had a majority on the Commission appointed in 1927.

The Dwelling Bill introduced in the Legislature in 1928 was the result. Its outstanding features may be briefly summarized.

(1) It proposed to take the long-overdue step of expanding the Tenement House Law to cover all dwellings, including one and two-family houses and hotels.

(2) It coined the new term "Dwelling Law" to distinguish the proposed enactment from the New York State Housing Law of 1926, which was of the constructive character commonly connoted by the term "Housing Law" in Europe. The previous monopoly of the term in the United States by restrictive codes such as those of Michigan and Iowa had already proved confusing.

(3) It classified building lots according to assessed valuation in 1927 , putting the dividing line at $\$ 2$ per square foot. The idea was to preserve the land not yet ruined by intensive building for a lower and more open type of construction insuring wholesome homes, somewhat after the manner of a zoning ordinance. Nearly all of Manhattan, $11 \%$ of Brooklyn, $7 \%$ of the Bronx and very small portions of Queens and Richmond fell in the high value category for which only intensive building was considered possible.

(4) It enlarged the minimum size of courts and yards even in the intensive zone, but permitted the height of buildings to be increased from one and a half times the height of the street to two times, provided set-backs 
were used, not only at front and rear, but at the sides. The resulting towers of pyramidal type appealed to many architects.

(5) There were other good points (such as larger minimum size of rooms and lower height of non-fireproof walk-ups), but there were others of at least doubtful tendency, such as the lower minimum of height of rooms ( 8 feet instead of 9) and one intake instead of two for the ventilation of interior courts.

(6) The weakest feature of the bill was its failure to do anything worth while for the improvement of existing tenement houses. It made a show of doing a number of things, but only a few exceptional cases were involved. The Commission was probably justified in feeling that the new-law tenements (built since 1901) were good enough to let alone. But the old-law tenements, which were unsatisfactory thirty years ago, and which still house from a quarter to a third of New York's population, deserved, after all these years, either some substantial improvements or a speeding of their elimination. The United Neighborhood Houses claimed that it was time to require a separate toilet for every family in such old houses as were to continue in use and that after a specified date, as 1935, the occupancy of rooms without windows to the outer air should be forbidden.

It was the violent opposition of real estate interests to the classification of lots and to the inclusion of one and two-family houses which prevented the bill's approval in 1928. The Commission was continued for another year, and three representatives of protesting groups were added to it.

The result seemed to some of us more a surrender than a compromise. The bill presented in 1929 was called a Multiple Dwelling Act. The one and two-family houses had dropped out of the picture, but the scope 
of the old law had been enlarged to include hotels and lodging houses, clubs, dormitories and the much debated apartment hotels. The classification of lots, by valuation, was cut out. No compensating improvements for the oldest buildings were added. The bill became a law in the last days of the session.

Although substantial concessions had been made to apartment hotels already built, their owners were by no means satisfied and took the new law promptly to court. They won a preliminary victory in the Supreme Court of the State on the plea that the provisions of the law constituted an invasion of the home rule rights of the city. The Court of Appeals, however (August 8, 1929), reversed the decision. The new law has apparently come to stay.

The United Neighborhood Houses, with the help of a few other civic organizations, have continued the uphill fight for improvements in the old-law tenements. In 1930 they secured from the Legislature two amendments of the Multiple Dwelling Law, one requiring the removal and replacement of all vertical-ladder fire escapes instead of only part of them, the other outlawing all cellar dwellings. The following year the latter provision was nibbled away to the extent of a possible year's grace and a possible auxiliary use of some cellar rooms for living purposes other than sleeping. In 1931 they secured the passage of a compromise bill forbidding, after January 1, 1936, the use for dwelling purposes of rooms which neither have windows to the outer air nor open directly into rooms which do. If this provision is enforced, it will end the occupancy of those unspeakable interior rooms which are two and three removes from daylight. 


\section{CHAPTER VI \\ RAPID GROWTH OF ZONING}

As OBSERVED in the last chapter, the improvement of housing conditions in the United States by restrictive regulation has, during the past dozen years, taken the form of zoning. In fact, the extraordinary spread of zoning has been one of the outstanding phenomena of the period.

Zoning is an exercise of the police power in the interest of public health, morals, safety and general welfare. This also is true of a tenement house law. Zoning accomplishes various good things looking toward orderly community growth which a dwelling law cannot touch. Even in the domain of housing, it is more effective in that it permits a differentiation of requirements in different districts. It had always been a weak point in the older codes that the standard of light and air for the whole city could only be what it was possible to impose at its center. Open and fairly cheap land in the outskirts had to be delivered over to tall tenements and tiny courts and yards if land values required that sort of development at the city's heart. Zoning has changed all that.

On the other hand, zoning has several serious shortcomings when regarded as a substitute for the older type of legislation.

(1) It deals only with the future-buildings hereafter erected-and can require no improvements in old structures. 
(2) It deals with light and air requirements, not with sanitation or fire prevention.

(3) It has nothing to say about repairs or cleanliness.

(4) It has a degree of flexibility not desirable for housing regulations, being always embodied in a local ordinance, which is much easier to amend than a statute enacted by the legislature. And there is always a Board of Appeals which has considerable leeway in waiving requirements in individual cases.

In other words, zoning is an admirable complement to a restrictive housing code rather than a satisfactory substitute for it. Both are needed. But the chance of working up public opinion to get a code after zoning has been secured appears dim at the present time.

Zoning may be defined as the application of forethought to the growth of a town in respect to the use, height and area of its buildings. It provides for the segregation of nuisance uses, the confinement of industry to certain districts and of business to certain other districts. Districts where neither business nor industry is permitted are residential, but residential districts may be further subdivided into those where only one and two-family houses may be built and those open to multiple dwellings. Industrial districts are sometimes divided into those for light and heavy industry. A distinction is sometimes made between business and commercial districts, one of the chief purposes of which seems to be to keep filling stations off of shopping streets. A recent innovation in Glynn County, Georgia, has been the creation of an agricultural district, but the usual practice is to class farms as residential.

Zoning is essentially a part of city planning, and some planners go so far as to oppose zoning until a general plan is under way. Practically, however, when local 
interest in zoning has developed sufficiently to demand the appointment of a Zoning Commission, it seems sensible to take advantage of that fact. Doubtless, the Zoning Commission should cultivate a planner's point of view in order to zone intelligently. Often the interest in zoning will lead logically to the appointment of a Planning Commission as the next step. But there are many small communities which can benefit by zoning, but are unlikely to go in for planning unless as part of a regional scheme.

In the early days of zoning, three sets of maps were made showing use, height and area districts respectively. It was found, however, that there was seldom any reason for giving height and area districts different boundaries from use districts, and that a single map based on use supplied every need. The greatest height is commonly permitted for office buildings near the center of the town, the next greatest for apartment houses. One and two-family house districts are commonly restricted to two and one-half or three stories, or to 35 or 40 feet. Neither apartment houses nor office buildings should be allowed to be built higher than the width of the street on which they face, ${ }^{1}$ if we are to have proper lighting of lower stories. But New York and some other large cities have unfortunately disregarded this natural limit.

Area (or bulk) restrictions provide for front yard (set-back), rear yard, side yards and courts. Where two side yards are required, the district is thereby automatically restricted to detached houses. Where only one side yard is required, the semi-detached house with party wall on the lot line is permissible. Where no side yards are required, houses may be built in rows.

Zoning has the great advantage of appealing both to

1 Except in so far as the street is widened, in effect, by a set-back. 
the idealist and to the practical man-the housing reformer and the realtor. It also appeals to the enlightened self-interest of every family owning a home on a street of homes who want protection against the intrusion of business, industry or other incongruous use. Because it assures him this protection, the intelligent home-seeker will choose a zoned town rather than an unzoned one to settle in, where he has any choice (e.g., in selecting a suburb for residence).

This is the sort of point which impresses the real estate dealer, who is quick to react to buyers' demands. He also has witnessed many examples of loss through the blighting of neighborhoods by the processes which zoning is designed to check. A pleasant block of detached single-family houses with well-kept lawns is first invaded by a tall brick apartment house, extending to the side-walk, casting a long shadow over its neighbors and shutting out summer breezes. Then a chain store appears at the corner and a filling station across the way. An exodus starts among the residents. Those who remain have lost all pride and pleasure in their homes. Those who have sold out and gone elsewhere have done so at a substantial loss. The first offender, the apartment house, was a parasite trying to secure without exertion of its own the pleasant vistas of grass and shrubbery which the neighbors had created by years of effort, to quote the opinion of Justice Sutherland in the Village of Euclid case (see pp. 131133).

The esthetic returns of zoning are very great, but must be regarded as fortunate by-products rather than as primary aims. American courts have not yet agreed to classify esthetic satisfaction among the general welfare objects for which the police power may be used, though they seem to be moving in that direction. Un- 
pleasant smells have long been regarded as a nuisance. Unpleasant noises are beginning to be so recognized. Unpleasant sights ought to have their turn soon. Meanwhile, health, morals and safety are objects always sure of support, if the regulations made are "reasonable".

Under the head of health, come the greater supply of light and air for homes and the removal from residential neighborhoods of the noise, smells and smoke of industry. Safety largely centers about traffic. It is industry and business, not homes, which bring a large amount of traffic. Their separation from homes therefore makes the home neighborhoods safer for playing children. The fire risk resulting from frame buildings too close together is lessened by the side yard requirements of a zoning ordinance. Normally, a child grows up in a safer atmosphere in a neighborhood of homes than in one where pool-rooms, cheap movies and speakeasies are sprinkled around and where loafing places are afforded by garages or barber shops, as local custom may prescribe.

Zoning, properly done, "increases individual and aggregate money values and returns" (Frank B. Williams in "The Law of City Planning and Zoning"). This point also, though most courts view it with sympathy, is not regarded by them as a direct object for which the police power may be employed.

\section{History of Zoning}

The history of zoning shows that its several elements grew up independently in widely separated localities. Thus, regulation of the height of buildings was tried out in a small way in Boston as early as 1892 and in Baltimore in 1904. And the establishment of use districts was foreshadowed in Los Angeles ordinances which were 
sustained by famous court decisions in 1911 and 1913.

Zoning as we know it, however, was the creation of the New York Commission weaving together these American precedents with certain European procedures, especially what had grown up in Germany under the name of Zoning. Going farther back, Williams points out that the seed of zoning came from France, but its development took place in Germany. The name inseparably connected with it is that of Franz Adickes, Bürgermeister, first of Altona, a suburb of Hamburg, and later of Frankfurt-am-Main. In the former city he worked out a system of zoning for height and area in 1884, and in the latter he developed use regulations as well in 1891. There were only two use districts, industry and residence. Business went anywhere. German cities have so much more home rule than American that they can carry on quite daring experiments without enabling legislation. The system spread widely in Germany after 1904 . In the early towns zoned, the development was sufficiently concentric to make the term appropriate. The old walled city, roughly circular and intensely crowded, formed the inner zone. It was encircled by a zone where the buildings were lower and open spaces more adequate. Beyond it was a villa zone of detached houses in ample gardens. As zones became split into smaller and more irregular districts, the Germans adopted the term "graduated building regulation". But zoning was the word imported to America, and zoning it remains, in spite of criticism, especially from the British Isles, where they have, perhaps, a more delicate reaction to etymological incongruities than is common with us.

The British Housing and Town Planning law of 1909, by the way, introduced most of the benefits of zoning, without the name, to unbuilt-on areas for which plans 
were prepared, but provided no machinery for extending them to built-up communities. This deficiency has caused a strong demand for such powers, which seem likely to be granted in the near future through the enactment of the Town and Country Planning bill, now before Parliament, as a Government measure.

Mr. McAneny, then Borough President of Manhat$\tan$, was responsible for the appointment in 1913 of a very able Commission on Height, Size and Arrangement of Buildings, whose report, after a study of what was going on in Europe and at home, led to the appointment of a Zoning Commission, and, in 1916, to the adoption of a zoning ordinance for the city of New York. The task of zoning New York was stupendous, but was carried out with remarkable skill and success. The invasion, just at that time, of the retail shopping district on Fifth Avenue by the loft buildings in which the needle trade industries were carried on, helped to win the support of business men for the zoning movement.

The extraordinarily rapid spread of zoning over the country in the last fifteen years may be laid to three main causes:

(1) Its own intrinsic merits. It met a need.

(2) The fact that it started in New York-a very conspicuous spot-and that this first example was well done and proved successful.

(3) Mr. Hoover's willingness to put the authority of his name behind it. This has been no small factor. In the early days of the Division of Building and Housing in the Bureau of Standards of the Department of Commerce, Mr. Hoover appointed an Advisory Committee on Zoning, composed of prominent men identified with the movement, who, with the assistance of Dr. John M. Gries, chief of the Housing Division, pro- 
ceeded to draw up several publications. The first of these was "A Zoning Primer," a seven-page pamphlet issued in 1922, revised in 1926, and widely distributed. This was ultra popular and frankly propagandist. "A Standard State Enabling Act" followed in 1923, which has already been used in 35 states. Reports on zoning progress have been issued at regular intervals in mimeographed form to the press and others interested. They include the number of zoned communities, their aggregate population, their classification by states. Occasional studies are made which tabulate for ready comparison the requirements of typical zoning ordinances or summarize court decisions. Special papers by zoning authorities have been given wide distribution in the same way,-as "Zoning and Health" by the late Professor George C. Whipple of Boston, and "The Constitutionality of Zoning" by Edward M. Bassett of New York. The Housing Division has thus made itself offcial headquarters for the latest information on zoning in the United States.

The last progress bulletin issued, bringing the story to January 1, 1931, showed 981 zoned communities in the United States of all sizes from tiny hamlets to the largest cities. Their aggregate population exceeded 46 million, nearly two fifths of the total population of the United States and more than two thirds of the urban population. The State of New York had the largest number of zoned communities with 159 and New Jersey next with 120. Then followed California, Illinois, Massachusetts, Pennsylvania, Ohio, Michigan, Wisconsin and Kansas in the order named.

A few states may have enough home rule to zone without an enabling act, but it has been considered safer for all to adopt one. Occasionally a state has to amend 
its constitution in order to zone effectively, as Massachusetts did in $1922^{2}$ and New Jersey in $1927 .^{\circ}$

\section{Court Decisions}

The events leading to the New Jersey amendment are rather instructive. New Jersey was a pioneer state in zoning. In the northern half of the state, within commuting distance of New York, every one reads New York newspapers, and most heads of families earn their living in the city. During the years the New York zoning ordinance was in preparation, they became as familiar with the subject as New Yorkers and saw how much zoning might do for them also in preserving the amenities of their home towns. The first New Jersey enabling act was passed in 1917-a very imperfect and incomplete statute, which was amended again and again until the legal situation became both confused and confusing. This was probably one factor in the court decisions which caused so much trouble, but the personal psychology of the judge who tried the Nutley case and of those who reviewed it must have counted for considerable. It has also been stated that, due to overconfidence, the case for zoning was rather carelessly presented. Be that as it may, the decision (Supreme Court of New Jersey, Aug. 13, 1923), afterwards confirmed by the Court of Errors and Appeals, held up Zoning progress in New Jersey for nearly five years.

2 "The General Court [i.e., the Legislature] shall have power to limit buildings according to their use or construction in specified districts of cities and towns."

8 "The Legislature may enact general laws under which municipalities, other than counties, may adopt zoning ordinances limiting and restricting to specified districts and regulating therein, buildings and structures according to their construction and the nature and extent of their use, and the exercise of such authority shall be deemed to be within the police power of the State. Such laws shall be subject to repeal or alteration by the Legislature." 
A Greek named Ignaciunas had tried to build a fruit store in the village of Nutley in a district set aside by the zoning ordinance as residential. The building inspector refused to grant a permit, and the case was taken to court. The decision was that the zoning ordinance, in so far as it prohibited the erection of a store in a residential district, was "void and violative of the rights of private property guaranteed by the State and Federal Constitutions" and that "said prohibition was not a valid exercise of the police power in the interest of the public health, safety and welfare."

In 1924, the Legislature repealed all existing zoning acts and adopted the Standard Enabling Act issued by the Department of Commerce, adding a paragraph to make abundantly clear its intention to give municipalities the power to establish separate districts for residence, business and industry. The Courts, however, ruled that the Legislature was without authority under the Constitution to bestow such power.

Thereupon, under the leadership of the New Jersey League of Municipalities and other civic bodies, the machinery was set in motion to amend the state constitution. After the amendment had been approved by two successive legislatures, it was ratified by popular vote (by a large majority) in September 1927. The former enabling act had then to be repealed and a new one adopted under the amendment, which was done in 1928.

Since then, New Jersey court decisions have been friendly and favorable. But it is possible that they still might not have been if a very sweeping decision of the Supreme Court of the United States had not been rendered in the meantime. There had been several previous ones covering one or another aspect of the subject, and there had been general decisions in a number of 
states. But the Euclid case was the first fundamental decision of the Supreme Court of the United States, and as such, is likely to be the Magna Charta of Zoning in this country for all future time.

Euclid, Ohio, is a suburb of Cleveland, and is predominantly zoned for residence. The Ambler Realty Company owned a large tract of land within a residential zone which they wished to sell for industry. They claimed that the zoning ordinance interfered with their constitutional rights.

The decision, given November 22, 1926, ${ }^{4}$ was written by Justice Sutherland. There were three dissenting voices, but the majority was a safe one. It upheld specifically the right to exclude stores from residence districts, factories from business districts, and apartment houses from single-family districts. It stated that new evils require new remedies.

"Regulations, the wisdom, necessity and validity of which, as applied to existing conditions, are so apparent that they are now uniformly sustained, a century ago, or even half a century ago, probably would have been rejected as arbitrary and oppressive. Such regulations are sustained, under the complex conditions of our day, for reasons analogous to those which justify traffic regulations, which, before the advent of automobiles and rapid transit street railways, would have been condemned as totally arbitrary and unreasonable. . . .

"And in this there is no inconsistency, for while the meaning of constitutional guarantees never varies, the scope of their application must expand or contract to meet the new and different conditions which are constantly coming within the field of their operation. In a changing world, it is impossible that it should be otherwise."

${ }^{4}$ Housing Betterment, December 1926. 
The case is put forcibly in the following paragraph: "Thus the question whether the power [exists] to forbid the erection of a building of a particular kind for a particular use, like the question whether a particular thing is a nuisance, is to be determined, not by an abstract consideration of the building or of the thing considered apart, but by considering it in connection with the circumstances and the locality. A nuisance may be merely a right thing in the wrong place-like a pig in the parlor instead of the barnyard."

It must not be supposed, however, that the door has been opened wide to every sort of regulation under the name of zoning. Time and again the Courts have repeated that the regulations must be reasonable. There are certain specific things, moreover, which various communities have endeavored to do through zoning, which the Courts have consistentiy pronounced unconstitutional. Thus it is definitely settled that zoning cannot be used to bring about racial segregation. Neither can it be used to prevent houses being built of less than a prescribed minimum cost. Nor can it be used to exclude hospitals (except those for contagious diseases) or schools from residential districts. Just what it can and cannot accomplish in the way of regulating bill-boards still remains to be proved. And there are other debatable regions whose determination is for the future.

Zoning stands for order as against hodge-podge. It stands for better home neighborhoods and therefore for better home life. It stands for stability in use and for greater permanence in home associations. In European countries, we often find love of home centering around a house and a parcel of land that have been handed down in the same family for hundreds of years. It is a rare thing in this country for a house to serve 
134 Recent Trends in American Housing

even two generations. In our perpetual tearing down -or burning down - and building anew, a good deal is lost that would have been worth preserving. Roots of affection and loyalty, striking deep into the soil, which would have served as anchors in a troublous life, are broken off ruthlessly and left to wither. 


\section{CHAPTER VII}

\section{CITY AND REGIONAL PLANNING}

IT is regrettable from every point of view that housing and city planning should be divorced to the extent that they have always been in the United States. In most other countries their history has been closely interwoven. In Great Britain town planning was actually introduced by housing reformers as a housing measure, and the passage of the Housing of the Working Classes and Town Planning Law of 1909 gave official sanction to the relationship. It is true that the two parts of the law are now (since 1925) in separate statutes, but the division took place rather because of bulk than through any divergence of interest.

In the United States most of our communities have been planned, in the sense that streets have been laid off on a map with rule and T-square in a checker-board or gridiron pattern before building began. Too often this primitive plan was drawn without regard to contour, orientation or natural features of any sort. Yet it cannot be said that spontaneous growth without a plan produced better results. Any one who has tried to find his way through the mazes of the North End of Boston is likely to take an indulgent view of William Penn's neat checkerboard. And Penn's plan had some other good features, as the two broad thoroughfares crossing at right angles at the center of his city and the system of small parks. It was not Penn's fault that his 
successors covered his central park at the intersection of Broad and Market Streets with the Philistine bulk of the present City Hall.

The plan of Washington by Major L'Enfant was a more elaborate and sophisticated piece of work and has made Washington easily our best planned city.

Just a little over a century ago, in 1828, Manhattan Island was planned north of the unnumbered streets. Real foresight was shown in the reservation of the Central Park area for a future playground in the midst of what was then a rural farming district. It is easy to criticize the gridiron pattern of the numbered streets, ${ }^{1}$ but to have continued the confusion of colonial New York would hardly have been preferable.

In a real sense, however, the art and science of American city planning is commonly regarded as beginning with the City Beautiful movement which followed the World's Fair in Chicago in 1893. The architectural and landscape effects of the White City made an extraordinary impression all over the country. Daniel Burnham was high priest of the movement, and the Chicago City plan its outstanding result. Charles Mulford Robinson wrote its literature.

Not all the results of the City Beautiful movement were happy. Elaborate civic centers sprang up all over the country and public buildings were erected in them, some of which were later discovered to be monstrosities. Tax-payers' money went into regrettable fountains and

${ }^{1}$ If the gridiron had been turned the other way and we had twice our present number of north-and-south thoroughfares, and half the number of east-and-west ones, traffic problems would be much simplified. In the matter of orientation, it would have had the advantage of doubling the number of buildings with east and west frontage, and halving those with north and south frontage. In the former every room gets direct sunlight some time during the day. In the latter, half the rooms never get it. 
monuments which their children will pay to have carted to the dump heap.

The next period buried the City Beautiful phrase in oblivion and went in strongly for utility. The automobile had created undreamed-of traffic problems. On them American city planning has largely focused in recent years. This phase dates approximately from 1909, when the Chicago city plan was completed and the $\mathrm{Na-}$ tional Conference on City Planning was founded to bring planners together once a year for an exchange of experience.

Along with streets and traffic and public utilities, water fronts, terminals and markets have attracted attention. Parks and playgrounds have fully held their own. And the civic center has crept back discreetly under the necessity of locating public buildings somewhere. Zoning since 1915 and 1916 has been adopted whole-heartedly. It appeals to the architect-planner's sense of order. It helps to solve his traffic problems. It has esthetic values which draw him even though he does not talk about them. And he does not mind its making better homes for children to grow up in. $\mathrm{He}$ may even regard it as an asset.

Zoning, then, forms a recognized connecting link between the fields of city planning and housing in the United States. Housing specialists realize clearly that, even apart from zoning, they depend in many ways on city planning, but only a handful of city planners show any perception of the fact, that the city and its plan exist primarily for the sake of the city's homes, and that where a large proportion of those homes are bad, neither the city nor its plan has fulfilled its most important function.

Where city plans are made for the built-up parts of an existent city, they involve the expenditure of large 
sums of tax payers' money in the process of carrying them out, which is necessarily spread over many years. The objects sought in such American plans include the widening of existing streets and cutting through of new streets, the redemption of water fronts, the establishment of parks and playgrounds, but never, so far, the elimination of slums as such. Philadelphia, for instance, has spent its millions cutting a boulevard from City Hall to Fairmount Park, but has never considered seriously having the municipality tear down the little court and alley houses which clutter the interior of its big blocks and help to keep up its death rates and its quota of juvenile delinquency. In this Philadelphia is not exceptional, but typical. New York raises huge bond issues to make elevated drive ways and tri-borough bridges, or to eliminate grade crossings, whose victims, however unfortunate, are only a few individuals per year. But if any one suggests that the city should pull down and rebuild the murderous dark tenements whose yearly victims are numbered by the thousands, the cry of socialism or paternalism is raised at once.

Boston offers the nearest approach to an exception which the writer has been able to discover. Its official City Planning Board, of which Ralph Adams Cram was then chairman, reported a plan in 1919 for improvements in the crowded North End. It was not called slum clearance, and there was no provision for re-housing. But it did aim at the improvement of housing conditions by the elimination of a group of small slum areas. $^{2}$ A broad traffic street was to be cut through the

- There have been a few instances scattered over the past forty years in which small parks and playgrounds have been established as much for the sake of getting rid of bad houses as for the resulting open spaces. Examples are Mulberry Bend in New York, Willow Tree Alley in Washington and Hell's Half Acre in Philadelphis. See also the pending proposal for Washington, briefly described in Chapter XV. 


\section{City and Regional Planning}

district. Interiors of blocks filled with rear tenements were to be cleared out and made into playgrounds and small parks. Narrow streets were to be widened and dead-end streets cut through. The city administration was behind the plan, but the Legislature failed to approve it. Various parts of the scheme, however, have been carried out since as separate projects. The third and largest of these, the Webster Place improvement, recently completed, has rid the city of a labyrinth of disgraceful old houses, some of frame construction, and will provide much needed play space in a district seething with children.

Admirable as this is by comparison, the time and effort required for its piece-meal accomplishment show the sluggishness of public opinion, and the entire lack of provision for re-housing the dispossessed tenants puts it in a wholly different category from slum clearance activities abroad, where the health and welfare of the dispossessed furnish the first incentive to action, though by no means the only one.

It is fitting, however, that this pioneer effort should have occurred in Massachusetts, the only state which has compulsory town planning and the only state in which the original town planning legislation was secured by a group primarily interested in housing. (For an account of the Massachusetts Homestead Commission and the compulsory Town Planning Act of 1913, consult the "Housing of the Unskilled Wage Earner," pp. 215-218.) Under the Massachusetts law, every city and town of 10,000 inhabitants or over must have a Planning Board "to make plans for the development of the municipality with special reference to the housing of the people." Each planning board was required to report annually to its city council or town meeting and to file a copy of its report with the Homestead Commission. 
This body was directed to call the attention of the mayors of cities and the selectmen of towns to the provisions of the act and to furnish the planning boards from time to time with information and suggestions.

While the appointment of a planning board was mandatory, there was no penalty for non-compliance. For the first few years, it was a case of the good complying with the law and the bad ignoring it. All the well-to-do residential suburbs appointed planning boards, while Fall River, New Bedford and Lowell with their wretched housing and high death rates, pointedly remained aloof. Nevertheless, in time the system justified itself. As one community after another fell in line, the pressure of publir opinion on those remaining became irresistible. At the beginning of 1931, there were 115 official planning boards operating in Massachusetts, with four more provided for, but not yet functioning. These included all but three of the communities over 10,000 - the cities of Chelsea and Marlboro and the town of Adams, - and a number of smaller ones. Such a result bears witness to the tact and patience of the Homestead Commission and its official successor, the Division of Housing and Town Planning in the Department of Public Welfare. (A consolidation act of 1919 abolished the Homestead Commission and transferred its functions to the new Division of Housing and Town Planning.) The number of zoned communities in Massachusetts at the same date was 70. The Division of Housing and Town Planning acts in an advisory capacity in regard to zoning, as well as other phases of town planning. It has put out some excellent educational literature, its secretary, Edward T. Hartman, being an acknowledged authority. Building codes have been adopted or revised under the auspices of the planning boards (as in the case of Springfield), and the or- 
ganization of housing companies has occasionally been encouraged. Although their housing activities are still largely latent, it is evident that in her compulsory planning boards Massachusetts possesses an instrumentality which other states would be the gainers by emulating.

Rather recently, the Federal Government, as represented by the Building and Housing Division of the Department of Commerce, has extended its influence to the furtherance of city and regional planning in addition to zoning. The Advisory Committee on Zoning has become, without change of personnel, an Advisory Committee on City Planning and Zoning. During the year 1928 this committee issued a "City Planning Primer," and a "Standard City Planning Enabling Act for the Use of States," while the Housing Division itself prepared a "Tabulation of City Planning Commissions" of the larger cities of the United States in mimeograph form, which has been repeated yearly. The edition appearing in the spring of 1931 gave 257 as the number of official planning boards in cities of 25,000 inhabitants and over, and 529 in smaller communities, 786 in all. In addition, 38 unofficial planning commissions were noted.

\section{Regional Planning}

Regional planning is the logical next step after local planning. Cities expand as to boundary. What is without today may be within tomorrow. Of what use is it to have wide streets within a city if there is a bottleneck outside? If the owner of a neighboring farm decides to cut it up into building lots and lays out a street system which has no relation to that of the city, there is a permanent inconvenience and incongruity. But unity of interests extends far beyond probable or 
possible city limits. Everything within commuting distance of a great center of population shares in its industrial, financial, recreational and cultural life. It is, for this larger unit that Regional Planning has been developed. No one can say where the movement will stop. State Planning has been talked of. Kern has written a book on National Planning and Bénoit-Levy one on World Planning. Regional planning is being more extensively carried out in England than any where else so far. The Germans have a big project in the Ruhr. France has several regional commissions at work, one covering the winter resorts on the Mediterranean coast.

A pioneering event of importance in the United States was the establishment of the Metropolitan District of Boston in 1889 with a unified system of police, water and parks, extending far beyond the city limits of Boston. Real regional planning has grown up within the last decade. The 1930 Department of Commerce Survey shows nine states with enabling legislation permitting County or other Regional Planning. Official County Planning Boards were said to be operating in Los Angeles and Santa Barbara Counties, Calif.; Glynn County, Ga.; Detroit and Wayne County, Mich.; Mercer County, N. J.; Putnam, Onondaga and Monroe Counties, N. Y.; Hamilton and Lucas Counties, Ohio; Allegheny County, Pa.; and Milwaukee County, Wis. The same report enumerates in addition the following official regional planning commissions: District of Columbia; Montgomery and Prince George's Counties, Maryland; the Boston Metropolitan District; the Niagara Frontier Region; Tulsa, Ponca City and Oklahoma City, Okla.; and Seattle, Wash. Midway of the decade, Cincinnati had completed a useful regional plan for herself and surroundings. 
In the Philadelphia region, a Tri-State Plan (Pennsylvania, New Jersey and Delaware) is being worked out by a privately financed commission, which, like the Regional Plan of New York, will have to depend on enlightened public opinion to carry it out.

The New York Legislature of 1923 authorized the Governor to appoint a State Commission of Housing and Regional Planning. Its housing activities will be described later. During its three years' life the Commission published a monthly bulletin dealing partly with regional planning, held regional conferences, secured enabling legislation and sponsored the creation of two regional boards, one on the Niagara Frontier, which, working with a Canadian board, became international in scope, and that of the Capitol District, including Albany, Troy, Schenectady, Cohoes and Rennselaer. The last official act of the Commission was the publication of a report (May 7, 1926) intended to furnish a fact basis for state planning. It deals with the forces which have shaped the economic development of the state,physical conformation, soil, forests, cultivated farm lands, natural highways, distribution of population, location of industries, the concentration that came with steam, and the decentralization which may come with the distribution of electric power. A final paragraph sums up as follows:

"Up to now we have been too greatly at the mercy of blind chance and of our necessities. We have been to a large extent the creatures of circumstances; we have permitted external forces to shape our lives, without making an effort to see how far those forces conformed to useful human purposes. With the powers that are now at our command, with the technical insight and the social vision which the State can now summon to its service, we may reverse this situation: instead of being the passive creatures of circumstance, we may become more and more the creators of our future. By 


\section{Recent Trends in American Housing}

using human nature and machinery intelligently, we can make them serve our human purposes. This is the final aim of the State plan."

The State Commission left the New York City region out of its activities, because the privately organized Committee on the Regional Plan of New York, set up by the Russell Sage Foundation in 1922, was already in possession of the field. It was more adequately staffed and liberally financed than any similar body had ever had the good fortune to be, upward of a million dollars having been devoted to it by the Foundation.

The Regional Plan of New York is the outcome of a suggestion by Charles D. Norton, who had been associated in working out the Chicago plan. He was especially interested in the redemption of water fronts and in bold plans for the future which public opinion would voluntarily carry out. The directors of the Sage Foundation adopted the project with the understanding that the improvement of living conditions should be the key motive. This might seem to assure the inclusion of housing, but it has not so worked out.

Mr. Norton was chairman of the Committee until his death in 1923, when he was succeeded by Frederic A. Delano. Frederic P. Keppel was executive secretary until September 1923, when Thomas Adams became its director. Mr. Adams had exceptional qualifications for such an undertaking. He had been executive secretary of First Garden Cities Ltd., the company which created Letchworth. He had been Town Planning Advisor to the Local Government Board of Great Britain and was brought to this side of the Atlantic in 1913 as Town Planning Advisor to the Canadian Government.

The region selected is roughly co-terminus with commuting distance from Manhattan. It includes 


\section{City and Regional Planning}

Long Island, Westchester County and other contiguous parts of New York State, all of northern New Jersey and Fairfield County in Connecticut-altogether more than 5000 square miles containing more than 400 separate administrative governmental units and a present population of eleven million. There were only nine million when the survey started. Its population studies indicate a probable population for the region of $21 \mathrm{mil}-$ lion in 1965.

One of the greatest lessons taught by the Regional Plan is that there will be ample room for that great population to live, work and play in health and comfort, within the region, provided they are properly distributed. It is stated that there would be room enough within the city limits of New York for every family now in residence to live in a detached house with a garden, at the low density of seven families to the acre, if they were spread out evenly. Tenements and skyscraper apartments would be wholly unnecessary if sufficient foresight had been displayed.

The first of two volumes containing the regional plan itself and most of the eight. volumes of preparatory studies and surveys began to be published in final form in 1929. The Master Plan is intended to serve as a framework for regional growth. It contains 471 concrete proposals, mostly connected with traffic and transportation, dealing with railways, subways and motor roads, with special emphasis on belt lines and unification of all systems. Parks, parkways and playgrounds receive adequate and sympathetic attention. A system of airports is strongly recommended. Local and regional zoning are essential features of the plan. Decentralization of industry and population is an accepted underlying principle. But housing is practically omitted from the picture. 
The survey series contains studies of the various basic industries, - chemical, metal, wood, food, clothing, textiles, tobacco and printing,-studies of population, of transit and transportation, of highway traffic, and of land values, but not of housing.

Facts may be found here and there of considerable housing interest. For instance, in Volume II B are the results of a questionnaire circulated among food workers on the relation of place of residence to place of work. Of the approximately 3000 who replied, $34 \%$ lived near enough to walk to work and $39 \%$ rode for less than 30 minutes. The membership mailing list of the Amalgamated Clothing Workers gave residence and workplace of 39,500 (Clothing and Textile Industries). Of these, $63 \%$ worked in Manhattan and 27\% in Brooklyn and Queens, while only $40 \%$ lived in Manhattan, $45 \%$ in Brooklyn and Queens and 9.3\% in the Bronx. The Women's Garment industry showed places of work and residence for over 52,000. Here, 89\% worked in Manhattan and $10 \%$ in Brooklyn and Queens, while only $49 \%$ lived in Manhattan, 29\% in Brooklyn and Queens and $22 \%$ in the Bronx.

These figures have so strong a bearing on decentralization that one wonders why they were not obtained for the other industries.

Among the most useful studies, for those interested primarily in health and housing, are those contained in Volume VII, Neighborhood and Community Planning. Here is to be found The Neighborhood Unit by Clarence A. Perry, describing the superblock idea, founded on school population, which is being put to the test at Radburn. Here is also a study on Sunlight and Daylight for Urban Areas by Wayne D. Heydecker and Ernest P. Goodrich, which brings together the latest ideas on sunlight and rickets and on sunlight and tuber- 
culosis. It deals with the bactericidal and therapeutic effects of sunlight, with orientation, the size of windows and of lots. A third part of the volume is concerned with Problems of Planning Unbuilt Areas and is by Thomas Adams, Edwin M. Bassett and Robert Whitten. The Whitten study based on the Perry scheme would seem to indicate an economy over the standard lay-out of about $50 \%$ of the development costs.

Volume VI of the survey, Buildings, Their Uses and the Spaces about Them (1931) is also of great interest. It contains a report by Mr. Adams on the Character, Bulk and Surroundings of Buildings, one by Mr. Adams and Mr. Heydecker on Housing Conditions in the New York Region (involving, however, no new field study), and one by Mr. Bassett on Control of Building Heights, Densities and Uses by Zoning.

The second volume of the Regional Plan is not yet published. Mr. Adams has said it will contain "constructive suggestions for a housing policy." It is, therefore, still permissible to hope.

On the completion of the Regional Plan, the Regional Plan Association was created to carry it out, with offices at 400 Madison Avenue to mark its independence of the Sage Foundation, and with George B. Ford as director. Mr. Ford's untimely death a few months later was a serious blow.

For those who find the big volumes of survey, maps and plan discouraging by reason of bulk, a little book by R. L. Duffus, called "Mastering a Metropolis" may be recommended. It is readable, accurate and sympathetic. One of its chapters ends with the following excellent statement:

"It cannot be too often emphasized that poor housing sometimes costs as much as good. If a city cannot give 
148 Recent Trends in American Housing

the mass of its people sufficient sunlight, fresh air and open spaces, it is to that extent a failure as a city, and the civilization in which it exists is a failure as a civilization." 


\section{CHAPTER VIII}

\section{THE LAND QUESTION}

SINCE the housing problem is caused by the wide discrepancy between the cost of a new dwelling conforming to modern standards and the purchasing or renting power determined by the income of about two thirds of the population, and anything which lessens the cost of an acceptable home without lowering the general income level tends toward the solution of the problem, such a reduction may helpfully be applied to any one of the several elements making up the cost of the home,i.e., land, building, financing or profit.

We take up at this point the consideration of the land. Normally, it ought to be a small item, comparatively speaking, in the cost of a home. Perhaps-though generalizations are dangerous-it ought to represent about one tenth of the total cost if the land is raw or one fifth if it is improved. Thus, if a small house and lot are to be sold for $\$ 5000$, it would be reasonable for $\$ 500$ of that to represent the cost of the lot if unimproved, or $\$ 1000$ if streets, sidewalks, sewer and water are already laid and paid for. In a large city, it might be reasonable to expect only a twenty to twenty-five foot frontage, on which of course, only a row house could be built, while in a small town, one ought to obtain a fifty foot frontage suitable for a detached house with adequate space on each side.

Where land is scarce and in demand, prices rise. This 
induces intensive building, and the profits received from intensive building increase the demand for and put up the price of adjoining land. The way in which zoning holds this pyramiding in check has already been discussed. So long as a district is zoned for detached single-family houses, lots simply cannot command prices at which only tall tenements could be built on them. That is why, of course, land speculators are hostile to zoning.

Henry George, in "Progress and Poverty," was the original Jack who attacked the Giant of Land Monopoly. His idea of a single tax on land, equal to its full rental value, to supersede all other forms of taxation, still seems to a dwindling, but devoted band of followers to show the way to the social millennium when all economic wrongs will be righted. That he established a real distinction between values earned by labor, manual or mental, and the unearned increment on land,-its rise in value due to the enterprise of the community, not of the owner,--few would now deny. But it is hard to see profit on land as any more an unearned increment than wealth acquired by trading on the stock market or gambling in futures on the corn exchange.

\section{The Graded Tax on Land}

What survives as Henry George's enduring contribution to economic progress is the Differential or Graded Tax, where either the whole real estate tax is put on land, buildings being exempt, or the tax rate on land is higher than that on buildings. In either case, though in different degree, the socially undesirable practice of holding land idle for a rise is discouraged by making its retention too costly, and building is encouraged because it produces revenue without adding to the tax burden. 
Under the old system, enterprise is penalized and inertia is rewarded.

With zoning regulations and a graded tax adopted at an early stage of community growth, exaggerated land values should not be able to develop.

A number of Canadian cities have adopted the graded tax system, and a few in the United States, the largest of which are Seattle and Pittsburgh. Seattle was an early convert to the graded tax, which has undoubtedly been an important factor in making it a city of home owners ${ }^{1}$ and of single-family detached houses. And these circumstances, again, have had much to do with its very low general and infant death rates,- - the lowest in any of our major cities.

Pittsburgh had gone too far in the direction of exceedingly bad housing before adopting the graded tax to produce comparable results, nor has it been in operation long enough. But it appears to have fully justified itself, and should show a noticeable increase in home ownership when the 1930 census figures are available, for it is claimed that the amount of building permits in Pittsburgh per 1000 of increased population, from 1914 to 1920 , exceeded those in New York by $25 \%$, those in Philadelphia and Cleveland by $66 \%$ and those in Detroit by $186 \%{ }^{2}$

The Pittsburgh Graded Tax law was enacted in 1913. It provided that the local tax rate on buildings as compared with that on land should be reduced $10 \%$ for the years 1914 and 1915, and an additional $10 \%$ each third year thereafter until the rate on buildings was only half that on land. This point was reached in 1925 . There is now a movement on foot to continue the process until

${ }^{1}$ One of the first ten in percentage of home ownership among American cities of 100,000 inhabitants and over.

2 "The Pittsburgh Plan," leaflet authorized by the Allied Boards of Trade of Allegheny County. 
the whole tax is shifted to land. Objectors claim that the graded tax law, even as it stands, tends to nibble away the standards set by the zoning ordinance through the incentive it offers to cover as much of the land as possible with buildings. A report on "The Graded Tax Law and Housing" by John Ihlder, executive director of the Pittsburgh Housing Association, dated June 21, 1929, suggests that this danger could be avoided and an incentive offered to raising standards if it were provided that open spaces about a building up to twice the amount required by the zoning law should be counted as part of the building for purposes of taxation.

The graded tax probably offers as strong a stimulus to building and to home ownership as was afforded by the New York tax exemption law of 1920. It has the advantage of being more economically sound, since it does not involve subsidy, and more equitable, in that it involves no discrimination between old and new buildings. It is rather surprising that the graded tax has not been more widely adopted in the United States. It may have suffered from the advocacy of the fanatic fringe of Henry George's disciples, and it has certainly lacked the official support which zoning has been fortunate enough to obtain.

\section{German and British Practice}

The German cities have a simple and direct method of controlling land values by owning a considerable part of their own area and leasing it for building purposes. Some of this land is part of their ancient heritage. Some they have bought in recent years as it came on the market at advantageous prices through forced sale or otherwise. The large degree of home rule in German cities, already referred to, makes this wholly a matter of 
local policy. It has been found in practice that city ownership of one third of the land is sufficient to prevent harmful speculation. Ulm is said to own $80 \%$ of her territory.

The method has considerable to commend it, but is unlikely to be adopted in the United States, as it is contrary to our habits and would require radical constitutional amendments.

An essential part of the English Garden City idea is that land shall be acquired at agricultural prices and that the increased values created by the community shall be conserved for the community instead of going to the developing company or to individual speculators. This will be more fully discussed in the next chapter. It is necessary for the working out of this plan that there should be no individual ownership of land, but that it should be held in trust for the community. The Mariemont experiment in the United States will also be discussed in the next chapter.

\section{Committee on New Industrial Towns}

During the war years, a small, but significant American group, the Committee on New Industrial Towns, sponsored several valuable studies by Herbert S. Swan and Dr. Robert Murray Haig ${ }^{3}$ and tried to persuade the United States Steel Corporation and some of the big ship-building companies to act on their findings. Unfortunately, there was no concrete result.

A résumé of gathered facts by Richard S. Childs, secretary of the Committee, in the Journal of the American Institute of Architects, reprinted in the volume "The

${ }^{3}$ See especially the latter's report on "The Unearned Increment in Gary," published in the March, 1917, number of the Political Science Monthly. 
154 Recent Trends in American Housing

Housing Problem in War and Peace," 1918, is still of interest.

"When the Lackawanna Steel Company put its big plant on a stretch of vacant land near Buffalo and offered work there for several thousand men, the town land was worth $\$ 1,279,000$. The city of Lackawanna, 14,000 population, grew up there, and the land values skyrocketed from $\$ 91$ per person to $\$ 644$ (the plant land being eliminated in each case). That inflated value for standing room was, in fact, enough to keep about half of the Lackawanna Steel Company employees from making their homes there at all, while many of those who do live there, huddle in dingy saloon lodgings and leave large areas idle in the hands of land speculators.

The net unearned increment which Lackawanna has given as a princely gift to miscellaneous lucky private land-owners and speculators is $\$ 6,788,000$, a figure large enough to explain why Lackawanna is mostly ragged and squalid instead of dainty and wholesome. The United States Steel Corporation has taken the logical next step by purchasing town land in various places at the same time as land for the new plant, thus in some degree anticipating and capturing the increment for the benefit of its workers. . . . Having thus acquired town sites, the Steel Corporation plans the streets and sells off the lots without attempting to reap a profit. But as population arrives, the unearned increment arrives too, and confers profits promiscuously upon the successive land-owners. In Gary, Indiana, which this Corporation created, in 1906, on vacant sand-dunes, this generous policy resulted in distributing $\$ 22,358,900$ net to various private owners and speculators during the next ten years, a heavy burden upon the steel workers in their efforts to buy housing accommodations or anything else." 


\section{The Land Question}

The Committee on New Industrial Towns were not urging employers to keep control of the land themselves, which would, it is true, conserve the increment in value for the inhabitants, but at the price of establishing the feudal atmosphere inseparable from company towns. That the employer should also be the landlord, and that a man should be unable to throw up his job without having to lose his home, is by no means a wholesome situation. Their efforts were directed toward the establishment of an independent, non-profit holding company or trust, under which the ownership of homes on lease-hold land should be encouraged. 


\section{CHAPTER IX}

\section{SATELLITE GARDEN CITIES AND OTHER NEW TOWNS}

In this chapter two streams run together-city planning and control of land values. Every new town, deliberately created, involves planning of some sort, good or bad. And the control of land values is potentially present, though it is not usually exercised. A number of new towns have been kuilt in recent years in the United States from a variety of motives. The new industrial towns built by the Government during the War have already been briefly discussed. New towns created by employers have been fairly numerous. The steel towns have been mentiond. In Morgan Park, following the Gary experience, the company retained ownership of the town site, though not in the manner advocated by the Committee on New Industrial Towns. Recent mining towns have been better than their predecessors, but not much to boast of. Company towns in the South provide sewer systems, bathtubs and other modern improvements for the district where the higher employees live, but leave the rank and file to do without. Hershey, Pennsylvania, is an example of a chocolate town, but has won no such place for itself as Bournville or Earswick in England. A good many developments fostered by Chambers of Commerce and others, which are loosely spoken of as garden villages, are really 
garden suburbs of a residential character, not complete communities at all. Kistler, Pennsylvania, built by the Mount Union Refractories Company, may be regarded as an independent town, as it is one and a half miles from the nearest community. Kohler, Wisconsin, is said to be an unusually attractive industrial garden village.

More interesting than one-industry towns, however good, is such a community as Kingsport, Tennessee. It is a business venture - the deliberate attempt of a railroad to increase its haulage by developing a thriving city in a rich, but sparsely settled region. The Carolina, Clinchfield and Ohio was the railroad. The beautiful valley of the Holston River was the scene. The Kingsport Improvement Corporation was organized to do the work. In it were represented a variety of other business interests in addition to the railroad. John Nolen was entrusted with the planning of the new town, and Clinton Mackenzie was its architect. Both have published considerable on the subject. Mr. Mackenzie wrote an article for the Saturday Evening Post and reprinted it as a pamphlet in 1920, under the title of "Industrial Housing," along with a number of plans, photographs and architects' drawings. Dr. Nolen can be most conveniently read in his 1927 book, "New Towns for Old." An illustrated volume, "Kingsport, a Romance in Industry," 1928, by Howard Long, gives historical, industrial, and miscellaneous information, but nothing about housing.

The town of Kingsport was incorporated in 1917. It was lucky in getting started before building costs rose. In 1919 it already had 10,000 inhabitants. There are now about 12,000 , with some 6000 more just outside the corporate limits. In the beginning modern six room houses rented at $\$ 25$ per month or sold for $\$ 2500$ 
on a fifteen-year payment plan. ${ }^{1}$ Shade trees were planted along all the residential streets, and the landscape gardening effects received much attention from the start. There is a Negro section which also has modern improvements, one is glad to note, and its due share of parks and playgrounds, and, apparently, of architectural amenity.

Among the interesting features of Kingsport are the charter of the city, written by the Bureau of Municipal Research (Rockefeller Foundation), which provides for an elected Council and an appointed City Manager, and the group insurance system which protects nearly all workers in Kingsport by health, life and accident policies. Ten large industrial concerns, the city itself and the Metropolitan Life Insurance Company coöperated in bringing this about. The corporation built a hotel, a hospital, a power plant, a golf course, and developed the various industries. Altogether, it sounds a good deal like Heaven. But if it has proved a paying investment to the railroad, why haven't more Kingsports been built?

Longview, Washington, was the creation of a group of lumber men who picked the site in 1922 and organized the Longview Company a year later. It is on the Columbia River, midway between Portland and the Pacific Ocean and offers excellent wharfage to sea-going vessels. In 1928, it was said to have a population of 12,000 with many industries and interests besides lumber.

Palos Verdes, a residential suburb of Los Angeles, is

${ }^{1}$ This happy situation did not last. A well-informed resident, writing June 1,1931 , says that rentals in Kingsport are higher than in any of the neighboring cities and much higher than they should be, as also are real estate values. The large manufacturers have met this problem by building homes for their employees, "modern in every detail," which they rent very reasonably. The Borden Mills have constructed an entire village of several hundred houses. 
Satellite Garden Cities and Other New Towns 159

a seacoast tract containing twenty-five square miles, which has been planned by the Olmsted brothers and Charles H. Cheney, who is now secretary of the Art Jury which passes on all proposed structures. Development began in 1922 and is expected to require an expenditure of 35 million dollars. It is already a rarely beautiful district. There is room on it for twenty thousand of the well-to-do and reasonably comfortable classes to live and play without crowding. But it has no place for the working man.

Rancho Santa $\mathrm{Fe}$, also in California, is, like Kingsport, the creation of a railroad, but is a wholly different sort of community,-residential, agricultural, picturesquely Spanish in architecture, and aiming at some degree of social exclusiveness.

The two California farm colonies, Durham and Delhi, will be considered later (Chapter XIII).

A farm city in North Carolina with an intended population of 10,000 has been planned by John Nolen for private development.

Several resort towns in Florida have been created de novo within the last few years, some of them very well planned.

Happy Valley, Tennessee, is another recent enterprise, the planning of which has been entrusted to the Nolen firm by the Bemberg and Glanzstoff Rayon Companies. In the valley, which lies between Elizabethton and Johnson City, and contains about thirty-two square miles of farms and woodlands, sites have been selected for three satellite communities. About $10 \%$ of the valley will be required for industry as it develops, $10 \%$ will be made a permanent park reservation, and $80 \%$ will be reserved for housing of various types, including farms, and the small local business centers needed. The valley has a great deal of natural beauty which it is 
proposed to preserve. In the first housing project, $35 \%$ of the dwellings were to have four rooms, $55 \%$ five rooms, and $10 \%$ six rooms. Employees of the industries were to have the privilege of purchasing their homes ("Regional Planning of Happy Valley," Tennessee, by John Nolen, in City Planning, July 1928).

\section{English Garden Cities}

The official definition of an English Garden City, adopted by the (British) Garden Cities and Town Planning Association, states that it is: "A town built for industry and health living; of a size that makes possible a full measure of social life, but not larger; surrounded by a permanent belt of rural land; the whole of the land being in public ownership or held in trust for the community." So defined, there are just two Garden Cities in the world,--Letchworth and Welwyn, founded in 1903 and 1920 respectively, and both within thirty-five miles of London.

It will be observed that a Garden City is not a garden suburb, not a dormitory town, where people sleep, going elsewhere to work. It is a self-contained industrial community, where people both live and labor. It is limited to a size where everyone may walk to work and go home for his mid-day meal. In other words, it is a community from which traffic and transit problems have been largely eliminated. No one spends hours night and morning tightly packed in a moving sardine box, swapping microbes with his neighbors, in order to get to and from his job. The healthful, but nearly obsolete art of walking is encouraged. The bicycle is again in evidence. The Garden City is a slumless town and must always remain so. Its maximum population is deliberately determined in advance, in the belief that 
it would cease to be such a good place to live in if it permitted itself to expand beyond the walk-to-work size. The thing to do when the maximum population is reached is to start another Garden City.

The permanent agricultural belt is expected to prevent involuntary extension-unregulated growth immediately outside the Garden Cities own borders. It also serves to keep town and country linked together,to give Garden City residents a continuous contact with country life, as it gives the farmers and their families the schools, theaters, shops and churches of the town conveniently at hand. The number of families per acre on the town-site is limited to twelve, with various requirements as to size of yards and height of buildings, which we in the United States arrive at by zoning, and further requirements as to the planting and care of yards, which zoning cannot reach. Overcrowding is permanently excluded and unkempt neglect equally so.

Holding the land in trust for the community is an essential part of the idea. It was bought at agricultural prices. The holding and developing company pays limited dividends to its stockholders-5\% in the case of Letchworth, 7\% in that of Welwyn, which was started when interest rates were high. All in excess will be used for the benefit of the community. No land is sold except for churches and other public purposes. Long leases are given to those erecting either factories or homes. There is mild architectural supervision. Public utility societies build homes for the small-salaried class. Local authorities, according to recent English custom, build for most of the manual workers. Land speculation is eliminated, and the increment of value created by the community, remains community property.

These two towns, now of about 17,000 and 7,000 in- 
habitants, extraordinarily healthy, very full of enterprise and public spirit, very charming to look upon, are among the most important social experiments ever made. The throng of pilgrims from all parts of the world going to inspect them must be a considerable nuisance to the residents. Although there have been no complete imitations anywhere, the influence of these two towns on better planning, better housing and the philosophy of decentralization and recentralization has been world-wide. The inspiring genius of it all, Sir Ebenezer Howard, died at Welwyn in May 1928, at a ripe old age, beloved as few men have been.

It is quite within the possibilities of practical politics that the great English cities may, within the next few years, adopt a policy of simultaneous attack on their housing and traffic problems by founding new satellite towns, wholly outside their own boundaries, but near enough to remain within their economic, educational and social orbit, to which industries and the homes of industrial workers will be removed. This policy has been advocated for years by the Garden Cities and Town Planning Association and has acquired the support of responsible statesmen, including the recent Minister of Health, Neville Chamberlain. Such cities, it is said, will be like wise parents who encourage their children, when the right time comes, to found separate establishments of their own instead of trying to squeeze all the growing families into the old homestead. The analogy also holds good in the perfectly natural selfishness which impels parents to cling to their children and cities to hold tight to the industries and population which they have.

The reader in search of information on the two English Garden Cities should consult C. B. Purdom's big volume on "The Building of Satellite Towns," 1925. 
Satellite Garden Cities and Other New Towns 163

Raymond Unwin's writings on the underlying principles of town planning and decentralization are numerous, convincing and authoritative.

\section{Mariemont}

Mariemont, Ohio, may perhaps be described as a civic adventure, the first American attempt to build a town in the spirit of the English Garden City. Bleecker Marquette in his article in the National Municipal Review, May 1927, calls it "An American Garden Village," and a prospectus issued by the Mariemont Company dubs it "A National Examplar." But its sponsors have shown so much zeal in describing what it is not, that one is almost afraid to attach a positive label to it. It is not a philanthropy. It is not a laboratory experiment. It is not paternalistic. It is not a profit-making scheme (quite obviously). Dividends are limited to $6 \%$ upon the money invested. Fifty acres of parks fully equipped, the drive and Grand Concourse along the top of the bluff overlooking the Little Miami River, the beautiful little English Norman undenominational church, the first public school buildings, and probably other items, are out-and-out gifts from Mrs. Emery. The company prospectus actually says: "It is a real estate development, pure and simple, on normal American lines, except that there is a limit put on the profit to the owner to give force to the idea that the maximum of return should not be extracted from the man who earnestly desires a home for his own use." And Mr. Marquette's article repeats a couple of years later: "Yet it is in the main a normal real estate development, except that everything about the town was planned in advance and built in the best possible way, and neither pains nor money spared in the effort to safeguard the 


\section{Recent Trends in American Housing}

future owner or builder." If those exceptions do not separate it wholly from "normal real estate developments," the writer needs to brush up on the meaning of the English language. But, after all, the desire to camouflage one's disinterestedness is so rare that it may be ungracious to protest.

Mrs. Mary M. Emery of Cincinnati provided all the finances for Mariemont, and Charles J. Livingood has acted throughout as her advisor and as president of the Mariemont Company since its organization. Something like fifteen years of discussion and preparation preceded the announcement of the project in 1923. The acquisition of the land, comprising 420 acres, had been going on quietly for years. The location is particularly beautiful, most of it on high ground commanding a wide view. The distance from the heart of Cincinnati is only nine miles, and the city limits are already close to the village. There are two sections reserved for industry, one on the bottom lands at the foot of the bluff and one on the higher level at the extreme west of the site. It is hoped that at least part of those employed in the works will live in Mariemont, but it is realized that most of the residents will be Cincinnati commuters.

The development aims to show how much better persons of small and medium income can live than they ordinarily do, where the best technique of town planning has been followed out and speculative profit eliminated. John Nolen is the planner. A variety of architects have been employed to insure against monotony. The first 350 houses and apartments built in the Dale Park section at the beginning of 1924 were all for rent, as it was felt that standards could best be set during the early years in that way. Rentals ranged from $\$ 35$ to $\$ 100$ a month. Later houses have been put up by private builders. No house in Mariemont can cost less 

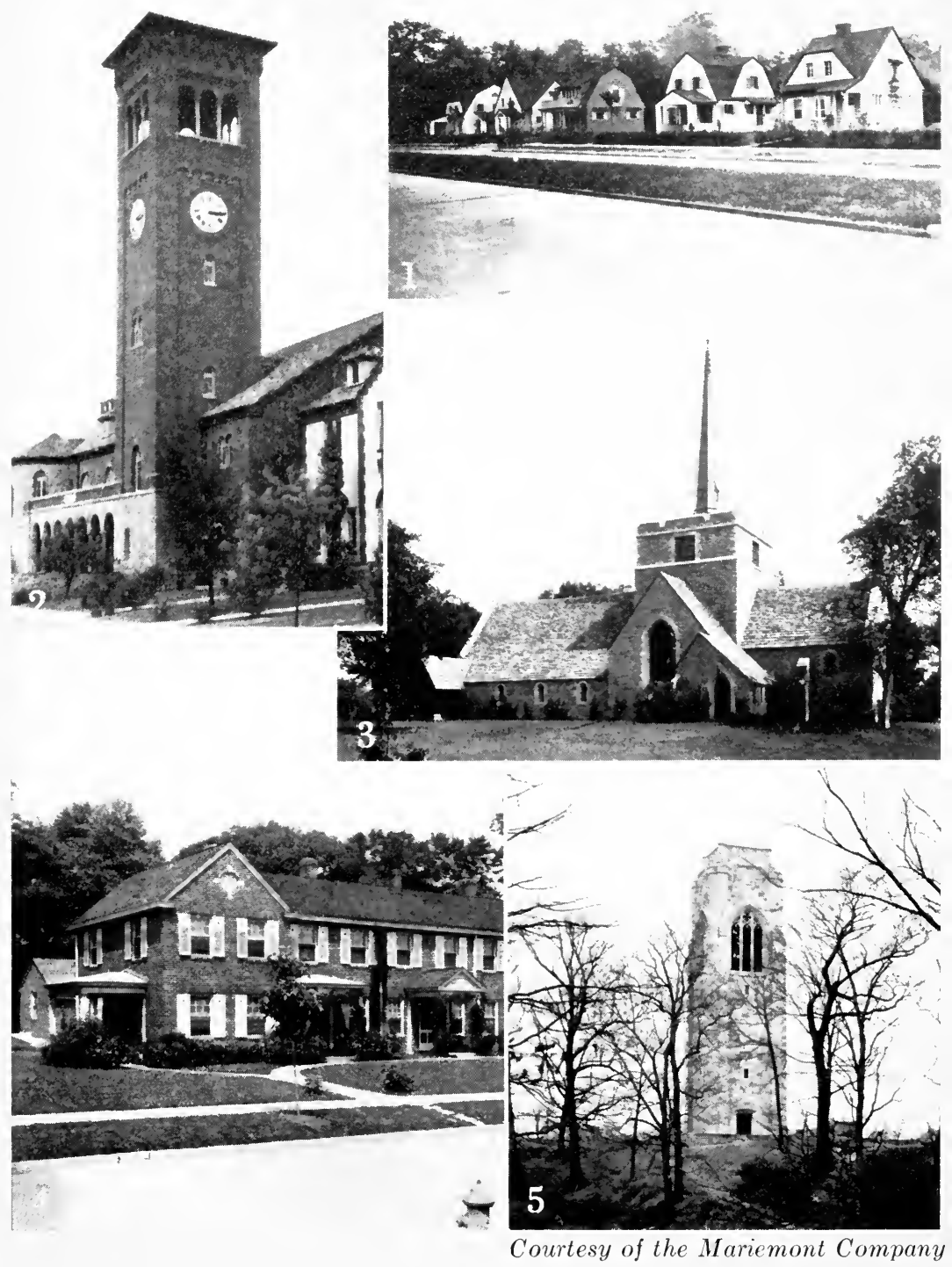

Mariemont garden village, Cincinnati. 1. Detached houses. 2. Recreation building. 3. Community church. 4. Group houses. 5. Carillon tower. 

Satellite Garden Cities and Other New Towns 165 than $\$ 5000$ or more than $\$ 25,000$. It is fully admitted that the unskilled wage earner cannot live at Mariemont. The skilled mechanic and the small salaried office worker can. An interesting feature of Mariemont is that most of the houses get their heat from a central plant.

Eventually some 750 lots are to be sold and houses built on them in the ordinary manner, subject to fiftyyear restrictions. The theory is the one adopted at Sunnyside, that after having lived under the restrictions so long and observed how much better off they are than their unrestricted neighbors, the owners may be trusted to retain them. At all events, it presents the easiest way out. It would be far more difficult in the United States than in England to build a town whose homes should be on leasehold land. In England such a plan is not contrary to custom or psychology. Its difficulties are chiefly financial-the difficulty of tying up such large sums of money with no quick returns.

Mariemont departs from the English Garden City definition not only in the matter of land tenure, but in the lack of an agricultural belt. English critics further claim that it is too small to be a really self-contained town (it will have a population of about 5000 when complete) and that it is too near Cincinnati to be anything but a suburb. In fact, it will shortly be included within the city limits. Even so, it is a delightful, worth-while and public spirited undertaking. Before Mrs. Emery's death in the autumn of 1927, she had seen her project sufficiently advanced to make its success assured.

\section{Radburn}

The next step in American town building with a civic motive was the creation of Radburn, N. J., by the City 
Housing Corporation of New York. The influence of the English Garden City was strong, and any departure from it was a matter of regret to the projectors. But the agricultural belt was promptly thrown overboard and land tenure ultimately followed it. The distance from New York necessary to make it a truly self-contained satellite was sacrificed to ease of operation and because the risk of failure otherwise seemed excessive, and this decision in turn made really cheap land out of the question. Optimum size had, therefore, to be reduced, though not so far as in the case of Mariemont. The tract on which Radburn is being built contains about two square miles against four for Welwyn and seven for Letchworth, but the agricultural belt accounts for much of the difference. Radburn's distance from New York is 17.5 miles. It is situated in Bergen County to the west of the Hudson River. It has rail and bus communication, but requires the new Hudson River bridge to make it readily accessible.

Radburn lacks the rolling country and well wooded tracts which give Mariemont so attractive a natural setting. Its one scenic possession is a nice line of blue hills on the horizon. Most of its beauty has to be created, but with the coöperation of planner, architect and landscape gardener, this is being done with noteworthy success. Clarence S. Stein and Henry Wright are the company's architect and planner here as at Sunnyside. With them have been associated Frederick L. Ackerman, Robert D. Kohn, Andrew J. Thomas, Thomas Adams, and Raymond Unwin.

Like Mariemont, Radburn will have an industrial section, but-also like Mariemont-if it is to serve as a demonstration of decentralization and redistribution by housing its own workers, it will have to confine its industries to those employing highly skilled-and there- 


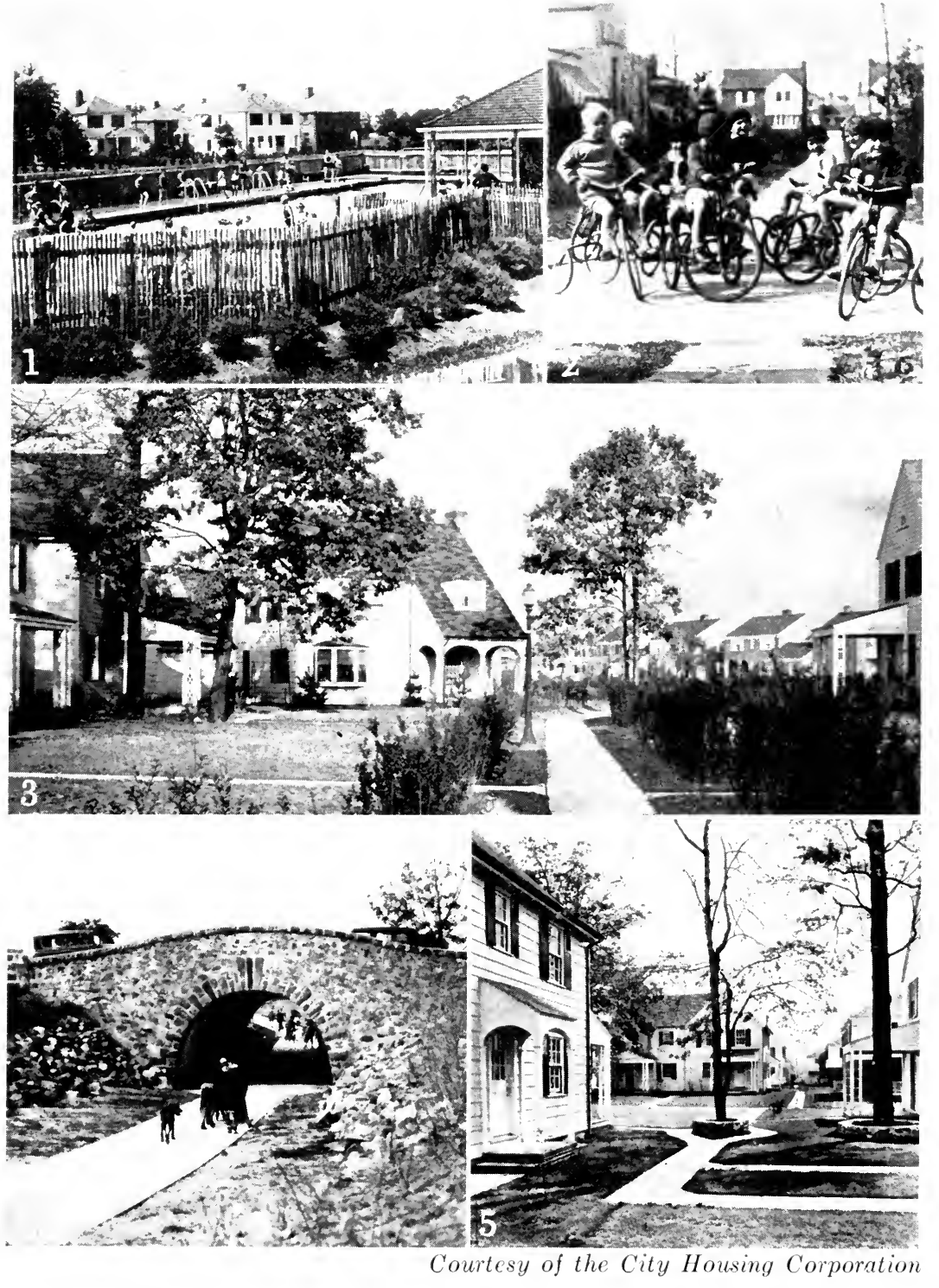

Radburn, New Jersey. 1. Swimming pool. 2. Radburn's best product. 3. The park "core" of a super-block. 4. An underpass. 5. The houses face on foot-paths and gardens. 

Satellite Garden Cities and Other New Towns 167 fore highly paid-labor. Just how far down in the economic scale Radburn will be able to reach remains to be demonstrated, but probably not below the $\$ 2000$ income class, as New Jersey has no tax exemption law. This situation is inevitable in the United States so long as we lack either housing by public authorities or an abundant supply of low-interest-bearing capital for limited dividend companies to work with. As in the case of Mariemont, Radburn is likely to be the home of a great many business, professional and other middleincome persons who earn their living elsewhere. In the case of Radburn, this may mean New York or the near-by Jersey towns of Paterson and Passaic.

Alexander M. Bing, president of the City Housing Corporation, is the father of Radburn, as he is of Sunnyside, and deserves highly of his fellow man on both counts. His initiative started them and his self-sacrificing devotion of time, energy and means, together with his large business experience in building and real estate, have made their success possible.

Radburn, in its planning, embodies the first attempt to carry out the super-block or residential-unit-basedon-elementary-school-population idea evolved for the Russell Sage Foundation by Clarence A. Perry. Its prospectus calls it "a town for the motor age", which is probably good sales psychology and is certainly accurate. The first 300 houses have built-in garages for convenience and esthetics. But far more fundamental is the super-block plan for safety, peacefulness and relief to taut nerves. The essential idea is that traffic streets pass around, not through it. Its own motor needs are served by a series of cul-de-sac driveways penetrating it from its circumference. No car enters such a driveway except to reach one of the dozen or fifteen houses located on it. Dust, noise, and especially danger to 
children and others are thus minimized. Moreover, the houses are built with their backs to these motor entrances. Living rooms face the other way on gardens and give access to footpaths which lead to the park occupying the core of each super-block. The school is located in the park, so that the children walk to and from it in absolute safety. Underpasses are built connecting super-block with super-block, so that the children may also visit their friends or go on an errand to the grocery without crossing a traffic street. Prophecy is dangerous, but there are already many signs that this feature of Radburn is destined to be widely imitated. In fact, the plan is so simple and so rational that there seems no excuse for going on in the old wasteful, nerveracking, extra-hazardous way.

The 1258 acres of land on which Radburn is being built cost in the neighborhood of $\$ 2,800,000$ or an average of about $\$ 2250$ per acre. The whole development is expected to involve an expenditure of fifty to sixty million dollars and to take ten years to carry out. The business depression may quite possibly prolong the period. Ultimate population is put at 25,000 .

The site was assembled in many parcels in 1927. Work began early in 1928. It was a district of market gardens in the rural township of Fairlawn, with only a handful of inhabitants. Roads, sewers, water, gas and electricity had to be provided. About $\$ 3,000,000$ worth of work had been completed by the end of 1929 , including 175 one-family residences, 10 two-family houses, and a garden apartment group for 92 families designed by Andrew J. Thomas. There was also a commercial block across the way from the new railroad station, of which the company will retain ownership. Homes in the first group were sold at from $\$ 7,900$ to $\$ 18$,200 and varied in size from four rooms with dining alcove 
and bath to eight rooms with two baths and a two-car garage.

The 1930 program, besides carrying on the earlier type of building, included a new section south of the railroad, in which six-room-bath-and-garage houses were built to sell as low as $\$ 7,400$. Terms of sale involve a down-payment of $10 \%$, and a monthly payment, in the case of minimum priced houses, of $\$ 60.75$, $\$ 11.10$ of which goes to amortize the mortgage. The township of Fairlawn built a modern school in the first super-block in time for the school year of 1930-31 while the company equipped a model play field adjoining it. One of the most popular features proved to be the swimming pool of varied depth, with its attendant life guard and swimming teacher. It was patronized to the limit by old and young through the summer of 1930 . A second swimming pool was built in the super-block south of the railroad to be ready for 1931 .

The Radburn Association was organized under New Jersey law as a corporation not for pecuniary profit. It was made up, to start with, of trustees representing the City Housing Corporation and prominent citizens of New Jersey. Ultimately, membership and control will pass to the residents of Radburn.

"The Radburn Association enforces the restrictions, maintains the architectural control, holds title in trust for the residents to the community property such as parks, maintains the parks, furnishes and supplements municipal services not furnished or only inadequately supplied by the borough, and finances and directs recreational and health work. It obtains its funds from an annual charge levied on the property covered by the restrictions. . . . The trustees of the Radburn Association determine its general policies, adopt the annual budget after public advertising and public hearings, 
and then leave the details of administration to a manager employed by them." (Sixth Annual Report City Housing Corporation, 1930, p. 6.) First Radburn Citizens' Association, composed wholly of residents, has worked so far in close coöperation with the Radburn Association. Other citizens associations will be formed as building progresses. The community life of the town (which on April 27, 1931, contained 335 families and 1015 inhabitants, of whom 267 were children under ten years of age is developing in an unusually happy and fruitful manner. 


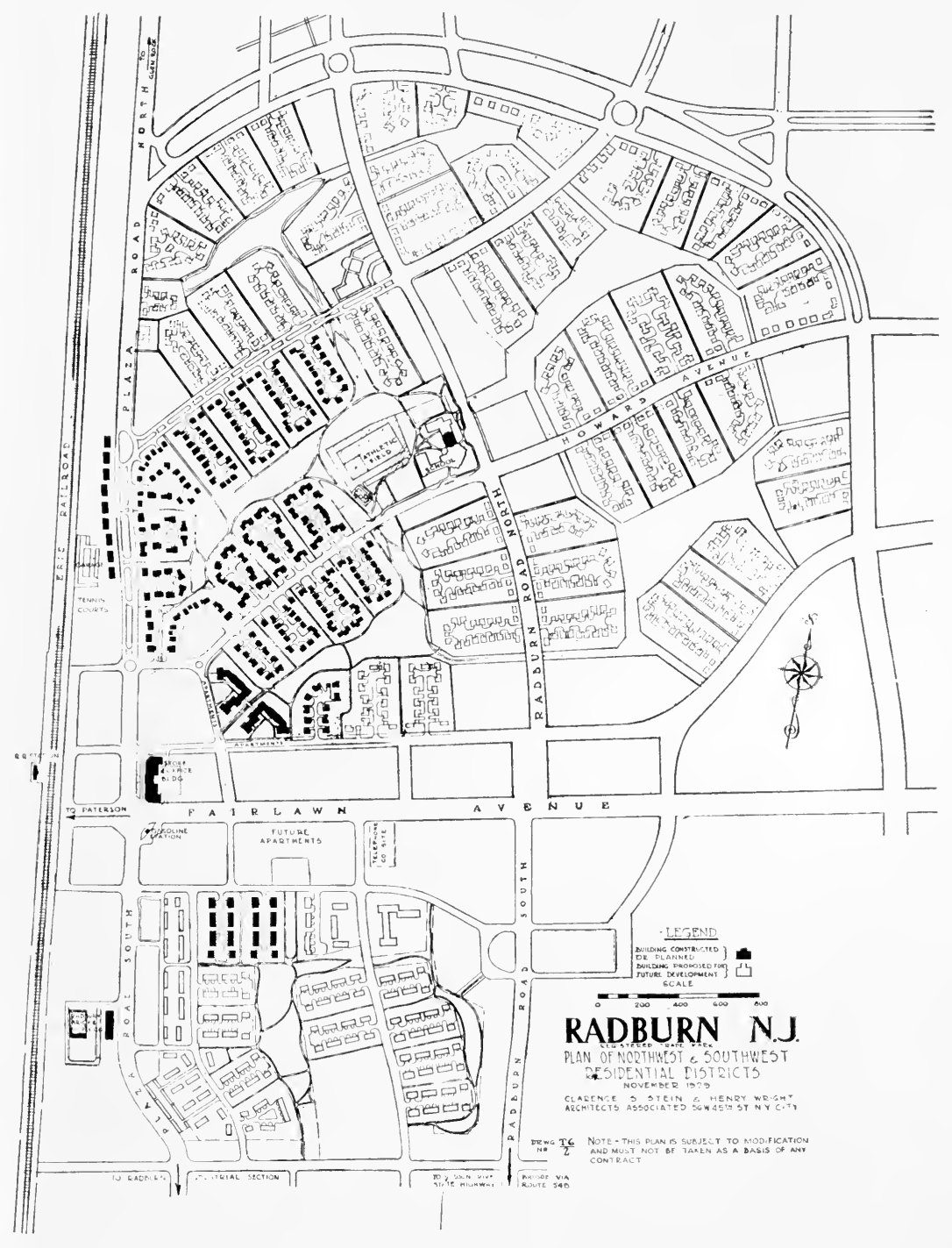





\section{CHAPTER X}

\section{THE ADVENT OF COOPERATIVE HOUSING}

THE advent and healthy growth of coöperative housing is one of the encouraging developments of recent years. But, in the interest of clarity, real coöperative housing should be carefully distinguished from joint tenant-ownership of apartment houses, which has also had considerable development in some of our cities since the War and has also, unfortunately, been called coöperative. Coöperation has such a definite meaning and such enormous development in Europe that it is highly undesirable for us to attach the label in the United States to something fundamentally different.

The so-called coöperative apartments of Park Avenue and other expensive localities in New York, as well as the interesting developments by the Queensboro Corporation at Jackson Heights for families of more moderate means, are instances in point. The purchaser buys his apartment single or duplex, absolutely as he would buy a house and lot. In addition, he has joint ownership with the other tenant-owners in halls, stairs, elevators, roof, basement, courts and gardens, and joins with them in managing the common property or in appointing an agent to do it for them. Usually, there are restrictions in his deed requiring him to get the approval of his associates for any family to whom he may wish to sell or lease his apartment. But what he leases or sells it for is nobody's business except his own. If he 
makes a profit, so much the better. He had always regarded his apartment as an investment as well as a home.

Joint ownership is a perfectly legitimate and often a convenient form of ownership, but it is not coöperative. Under real coöperative ownership, no person holds individual title to the property he occupies. The coöperative society holds the title, and the individual subscribes to shares in the society equal to the capital value of his apartment or house, on which he has a 99-year (or other virtually perpetual) lease. Usually he pays for his shares over a term of years. His rent is calculated to cover expenses including purchase of shares if not already paid for. If it does not, it must be increased. If there is a surplus, it can be diminished. If he moves away, the society buys back his shares for the exact amount he has paid for or on them and cancels his lease. There is neither profit nor loss in the transaction. If he wants to sub-let during a temporary absence, he must not make a profit from it. It is provided in the articles of incorporation that if the society is dissolved, after its obligations are paid, the members may receive back what they put in, but any surplus shall be devoted to a specified public purpose. Where this is not the case, as occurred with some of the Brooklyn societies, a strong inducement is offered the members by any marked rise in real estate values to sell out and divide the profit. This also is perfectly legitimate, but it is not coöperative housing.

Members of a real housing coöperative are homeseekers, not profit-seekers. It is because they have put it out of their own power to commercialize their undertaking that European governments show them so many favors in the shape of housing loans at low interest rates, tax exemptions, and-in the post-war yearssubsidies. If persons who thus acquire homes below 


\section{The Advent of Coöperative Housing}

market rates were free to turn around and sell them at market rates, most of them would quite naturally do so, and the Government would have failed to accomplish its purpose of securing better health and better environment for families unable to achieve them unaided and would have interfered in a harmful way with private business.

On the other hand, it is precisely these financial favors offered by their governments which provide the chief inducement to organize coöperative housing societies in European countries. So far, in the United States, no similar inducement is offered except by the New York State Housing law of 1926 and, to a lesser degree, by the Wisconsin Act of $1919 .^{1}$

One group of Finns in Brooklyn formed a coöperative to acquire homes for themselves in 1916 and another group organized in 1919. Omitting some early idealistic experiments which have only a historical interest, this was the beginning of coöperative housing in the United States. Both groups proved that their plan was work-

${ }^{1}$ An account of coöperative housing in the United States can be found in Chapter V (pp. 90-95) of Bulletin 437 of the United States Bureau of Labor Statistics, "Coöperative Movement in the United States in 1925" (other than agricultural), published in 1927. An article on the Milwaukee experiment is in the Monthly Labor Review for December 1922, pp. 155-158. The February 1926 number of Coöperation, monthly organ of the Coöperative League of the U.S. A., lists and briefly describes the Brooklyn and other New York societies of that date, while its December 1926 and February 1928 numbers feature the United Workers' Coöperative and the Amalgamated Coöperative Apartments respectively. The Amalgamated and other recent projects coming under the State Board of Housing are described in its reports for 1928, 1929, 1930 and 1931. Louis H. Pink in his "New Day in Housing" gives some account of the United Workers', Amalgamated and Rockefeller houses. The last named have issued literature of their own.

The Coöperative League of the U. S. A. (167 West 12th St., New York) have assisted the movement by issuing ten-cent pamphlets on "The A-B-C of Coöperative Housing" and a "Model Lease for Cooperative Apartment House," beside some descriptive pamphlets on European coöperative housing, and have assisted various groups in drawing up their constitution and by-laws. 


\section{Recent Trends in American Housing}

able, though there was nothing spectacular in either the quantity or the quality of their results. They had numerous imitators with varying histories. In February 1926 the Coöperative League listed twenty-six of these small housing societies in Brooklyn as being genuinely coöperative, admitting there might be a few more. The addresses show them as localized to a surprising degree, all lying between 40 th and 47 th streets and between 6th and 9th Avenues in South Brooklyn. The members are mostly, though not exclusively, Finns and Scandinavians, who brought the coöperative habit with them from the old country. What they have built or bought are small apartment houses, mostly four-story walk-ups, accommodating from 8 to 32 families.

The Bureau of Labor Statistics (Bulletin 437), getting returns from 22 of the Brooklyn societies, showed that they included 534 families, and 21 of them reported the cost of their land and buildings as aggregating $\$ 2,176,000$. The monthly payments of members ran from minima of $\$ 12$ for three rooms, $\$ 16$ for four rooms and $\$ 20$ for five rooms, to maxima of $\$ 46.50$ for three, $\$ 62$ for four and $\$ 65$ for five rooms. Doubtless much of this difference was due to date of construction, and some would correspond to varying standard, while there would be a residuum dependent on efficiency of management. Those who got started before building costs soared were extremely fortunate and must have realized it when the housing shortage and rise of rents hit New York. Those who are paying most are not going beyond the market rentals for modern apartments in that section of Brooklyn and are acquiring collective ownership as they go along. On the other hand, they have tied up a certain amount of capital from which they would otherwise be receiving returns. They are 
an example of coöperation for its own sake without any assistance from public authorities.

Meanwhile miscellaneous coöperatives had been started in Manhattan and the Bronx (which the Bureau of Labor Statistics somewhat surprisingly distinguished from Brooklyn as "New York City"), 13 being listed by the Coöperative League and 9 by the Bureau. Some were groups of professional people, some were Jewish organizations, and the largest one (United Workers), while incidentally Jewish, was primarily left wing labor. The six societies reporting to the Bureau of Labor Statistics gave monthly charges ranging from minima of $\$ 18$ for three rooms, $\$ 24$ for four and $\$ 30$ for five, to maxima of $\$ 54, \$ 72$ and $\$ 90$ respectively. Initial payments for stock (including Brooklyn) had varied from $\$ 100$ to $\$ 2000$ per family, not always in proportion to the number of rooms. Capital cost per apartment in the older buildings ran from $\$ 2000$ to $\$ 4313$, and in the newer buildings from $\$ 3094$ to $\$ 6750$. Neither the United Workers, nor the next largest group, Yiddische Coöperative Heim Gesellschaft, had built at the date when the federal report was compiled.

At Sunnyside, in Queens, the City Housing Corporation built two apartment houses in 1924 and 1925, which it sold to coöperative housing societies organized under the wing of the Coöperative League. In the very successful Sunnyside development, the coöperatives proved the least successful feature and have not been repeated either at Sunnyside or Radburn. The trouble is psychological. The families went into the societies, not because they were coöperative, but because they offered a way to get good apartments at low cost. These families were a heterogeneous group with nothing in common but the desire for a home. Few, if any, of them had known or cared anything about the coöperative 
movement or the coöperative spirit. Apartments to rent and houses to sell at Sunnyside went like hot cakes. Only the coöperatives dragged. And there are usually one or two coöperative apartments listed for re-sale (or for re-lease with transfer of stock, to be accurate).

Coöperative housing cannot be a success unless the participants coöperate. When the group gets together spontaneously to build, there is almost necessarily some bond of friendship, of race, occupation, trade union or religion in the first place, a bond which has been greatly strengthened by the time they have gone through the processes of site purchase, plan making, financing and building. But where some one else-in this case the City Housing Corporation-has done all that in advance, the chance home-seekers who form the coöperative society in order to get the apartments have passed through no such disciplinary apprenticeship. The same is true of the Rockefeller coopperative apartments. Here the company will retain the management so long that a coöperative spirit may possibly grow up among the tenant owners before they take it over. At the present stage, there seems much more likelihood of such a favorable outcome at the Paul Laurence Dunbar than at the Thomas Garden Apartments.

Something similar to the Sunnyside experience seems to have occurred in Milwaukee, where an interesting experiment was carried out, which we are frequently assured was highly successful, but which has so far shown no signs of healthy growth.

The Garden Homes Company was organized and financed in a manner so unusual in this country that it must be noticed at some length in a later chapter. What we are concerned with here is the coöperative feature, which was introduced by the promotors to preserve the mobility of labor. Between 1921 and 1923, 
105 small detached houses were built in open layout, at an average cost, counting land and improvements, of about $\$ 5000$. Instead of selling them, stock in the company was sold to an equivalent extent. The monthly payment on a six-room house was $\$ 50$, covering stock purchase, interest, taxes and up-keep. The houses were quickly taken, and it is always said that the takers were very much pleased with them. ${ }^{2}$ But there has been no move in all these years to build more houses. According to a letter from Mayor Daniel W. Hoan of Milwaukee of August 21, 1928, quoted by Mr. Pink in "The New Day in Housing" (p. 163), some of the tenant owners, not having had the coöperative idea sufficiently "sold" to them in advance, became dissatisfied at not owning their homes outright. Wherefore the law was amended to permit a deed to be given to those who wished it. It is not stated how many availed themselves of the privilege. But obviously it marked the end of the venture as purely coöperative.

The story of the United Workers' Coöperative and of the Yiddische Coöperative Heim Gesellschaft, both of New York, must be briefly related here, although one ended in disaster and the other barely escaped it, bearing witness to the enormous difficulty of city workers' solving their own housing problems without community aid, where they are trying to secure something of higher standard than is currently offered them. At all events, these two groups staged a gallant attempt.

The United Workers' Coöperative Association was organized by a radical, predominantly Communist group including many trades and races. Many of them were Russian or Polish Jews who had been living under de-

${ }^{2}$ For a late reference to this project as an unqualified success, see a short article by Mayor Hoan in the July, 1930, number of The American City. 
cidedly poor housing conditions on the Lower East Side or in Brooklyn. They had had several years' successful experience in operating a large summer camp on coöperative principles as well as a small apartment house on Madison Avenue. Their early moves seemed eminently sagacious. They bought five wholly undeveloped city blocks facing on Bronx Park and running north from Allerton Avenue, and built 339 five-story walk-up garden apartments on the first block with a coverage of about 50\%. These were at the time (begun in 1926 and finished early in 1927) of unprecedentedly high standard for workers' homes, though the Amalgamated apartments, which followed, were even better. A similar group of buildings containing 365 apartments went up on the second block in 1928. An effort was made to organize for the third block under the State Housing Law, but apparently they had already undertaken more than they could carry through. They had fallen in arrears as to interest, amortization, taxes and assessments to an amount in excess of $\$ 200,000$. The title company which held the first mortgage instituted foreclosure proceedings. It looked as if they would lose their homes and as if their fellow workmen who had made them a second mortgage loan would lose their money. Fortunately well-wishers came to their rescue and a compromise arrangement was worked out. The unbuilt-on land was lost. The two developed blocks are owned today by the Workers' Colony Corporation, the common stock of which is held in trust for the tenant investors, and the preferred stock of which has been exchanged for the second mortgage bonds held by their comrades. The arrearage has now been paid off and the management of their enterprise, temporarily controlled by the first-mortgage holder, has been returned to the stock holders. 
The Jewish Nationalist group who organized the Yiddische Coöperative Heim Gesellschaft represented various occupations, including printers, clothing workers and many small tradesmen. They built on Giles Place in the Bronx within sight of ground where the Amalgamated houses went up a few months later. Like the United Workers, they got started a lap ahead of the State Housing Board, and failed to realize at the outset how much they would gain by reorganizing under it. They built 220 apartments in five-story garden walk-ups. The apartments were of excellent standard, but cost a great deal more than the estimates. The coöperators were unable to raise the additional money. Efforts to save them failed. Mortgages were foreclosed, and they were not even able to stay on as tenants.

Another Jewish group has been more fortunate-the Jewish National Workers' Coöperative Homes Association, which built still farther north in the Bronx at the junction of Williamsbridge Road and Mathew Avenue. Their first group containing 125 apartments was finished in 1927 and the second, of about the same size, early in 1928. For their third project, completed in November 1928, they secured the approval of the State Board of Housing. For this unit, containing 128 apartments, the Farband Coöperative Housing Corporation was organized. The Farband has successfully demonstrated the possibility of automatic elevators in a six-story apartment at no higher rentals than would be necessary in a five-story walk-up. In its wake followed the 1929 project of the Amalgamated Housing Corporation and the Grand Street development of Amalgamated Dwellings in 1930. The Farband rentals have, indeed, been notably low. They average only $\$ 9.65$ per room, and the minimum rental is $\$ 8.80$. This is in contrast to the earlier buildings of the Jewish National Workers, where 
carrying charges average about $\$ 16$ per month per room. The difference is much greater than can be explained by tax exemption and suggests the benefit of the expert financial advice obtainable from the State Board of Housing. In connection with the low rents in the Farband as compared with other State Housing Law enterprises, it must be pointed out that they cover $69 \%$ of their site-almost as much as the $70 \%$ permitted by the Tenement House Law. They still have well-lighted rooms because the peculiar shape of their site gives them an unusual amount of street frontage, but their inner landscaped court is much reduced in comparison with the delightfully spacious ones of the Amalgamated.

The Amalgamated group have unquestionably produced the best and most successful coöperative housing thus far seen in the United States. A substantial part of this success is due to the State Board of Housing, of whose usefulness they are a shining example. The financial data concerning them will, therefore, be given in connection with the State Board of Housing (Chapter XIV). The present section will be descriptive of standard attained.

The Amalgamated Clothing Workers of America are an extremely strong organization with a membership of over 50,000 in the metropolitan district of New York. Since 1910 they have succeeded in transforming the men's clothing industry from one of sweat shops, long hours and notoriously low pay to one carried on during a 44-hour week in new sanitary factories with a wage scale above the average. They have founded two banks in New York and Chicago for their savings, which have an aggregate capital of 13 million dollars. Much of this record of achievement is due to the leadership of their president, Sidney Hill- 
man. But leadership implies following, and the years of struggle have welded the members into a real brotherhood.

It was natural that they should take up coöperative housing. They had talked about it before the United Workers started and had gone so far as to purchase 13 acres of undeveloped land at the southeast extremity of Van Cortland Park. Fortunately, as it turned out, their plans remained in cold storage until the State Housing Board was in action. Their site included a whole city block of irregular shape and part of the adjoining block. It is near the Mosholu Parkway subway station (above 200th Street) in the Bronx and in the immediate vicinity of the new DeWitt Clinton High School and the new Hunter College, as well as of the park. A large reservoir offers a lake view from many of their windows. They built five-story walk-ups of light colored brick covering about $50 \%$ of their land with an interior park of exceptional beauty. The rooms are large, sunny and airy. The 303 apartments contain from two to six rooms, but predominantly three or four. There are 1185 rooms in all. Living rooms average 207 square feet and bed rooms 166 square feet. Bathrooms and kitchens are thoroughly modern. All refuse is disposed of by chutes which connect each apartment with incinerators. Their steam heat is produced by oil burners. Much credit belongs to the architects, Springsteen and Goldhammer.

Much credit also belongs to A. E. Kazan, president of the Amalgamated Credit Union and of the Amalgamated Housing Corporation, which owes an incalculable amount to his enthusiastic, sagacious and devoted leadership.

Opening ceremonies in the first buildings were held on Christmas day 1927. The buildings in the adjoining 
block were finished in the late summer of 1928 . Additional land in the block west of the second group was secured and six-story elevator apartments built on it during the year 1929, being completed in December. There are 208 apartments in this group, making 511 for the whole development. Adjacent to the new group the coöperators maintain a really delightful playground for their numerous children, shaded by trees already growing on the site. The coöperative spirit, under Mr. Kazan's leadership, has developed in a wonderful way. The tenant owners buy electricity, milk and ice wholesale and distribute it themselves. Being in a residential neighborhood, they cannot have neighborhood stores in their basement, but can and do have coöperative commissaries to provide themselves with groceries, meats, fruit and vegetables. Except for the fact that they cannot sell to outsiders, these establishments are indistinguishable from coöperative stores. They handle an excellent quality of food and serve to keep down the cost of living.

The women run a tea-room in the basement. In the evening the men gather there to smoke, talk and play checkers or other games. Two women on duty by turns in the adjoining kitchen serve tea or coffee and cakes at 15 cents per order. After school and on summer afternoons, children can be served with ice cream or soft drinks. The profits of this and some other activities have been invested in an autobus which carries the children to and from school and serves for picnics and excursions. The basement also houses a barber and a cobbler, as well as a kindergarten, a library and an auditorium. During the summer of 1930 they employed a recreation leader to take their children to a swimming pool in the forenoon and to the park for games in the afternoon or off on all-day excursions. They had 


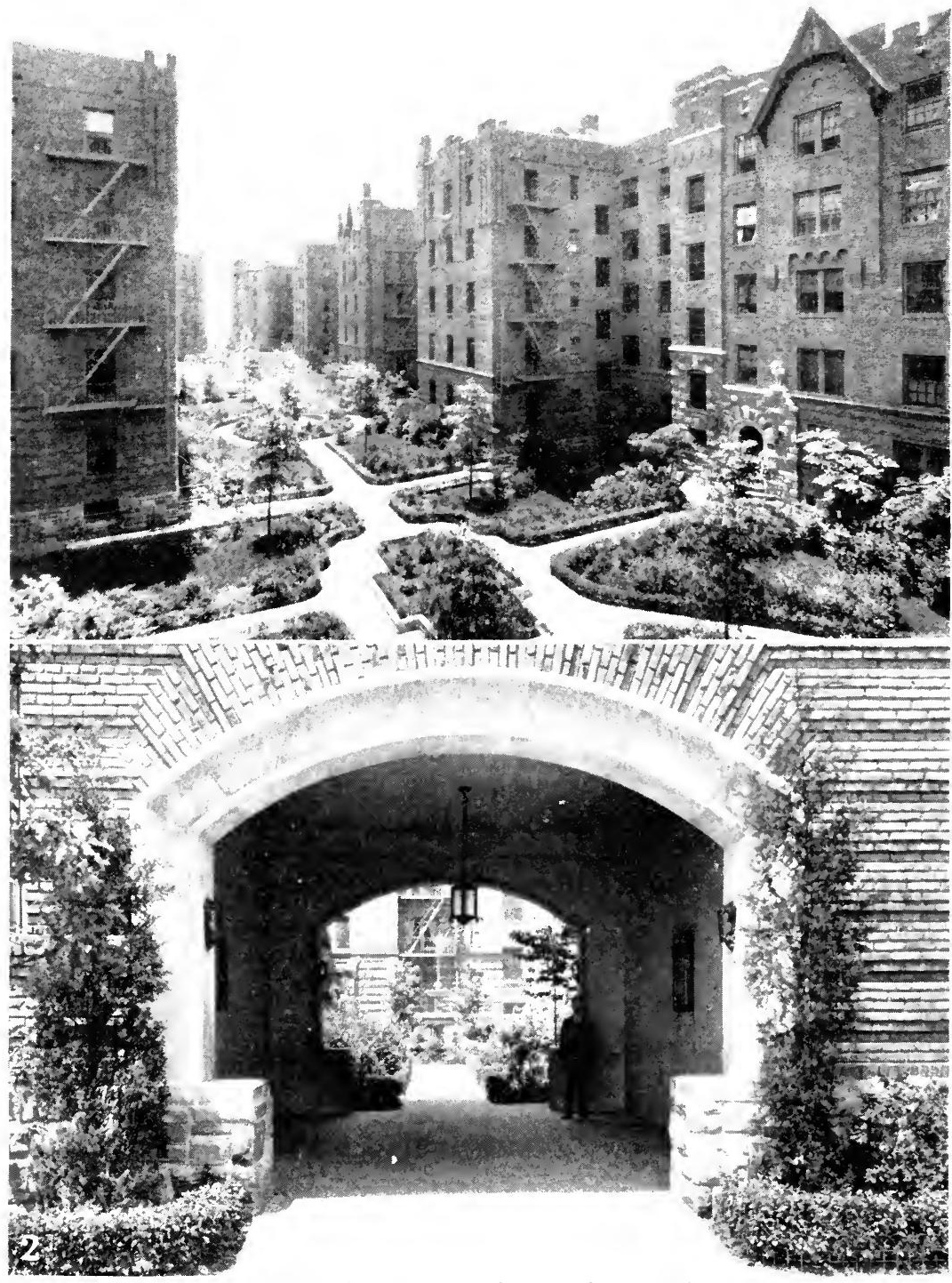

Cometesy of the Amaluamated Honsing ('orponation

Amalgamated Housing Corporation. Bronx. New York. 1. The gardens of the first unit. 2. Main entrance with a glimpse of the nomised land beromel. 

most of the advantages of a summer camp at nominal expense without leaving home.

It is only fair to say that, while the number and completeness of these coöperative activities under the Amalgamated Housing Corporation are unique, similar activities had in many cases been started even earlier by the United Workers, Yiddische Heim Gesellschaft and Jewish National Workers, who deserve credit as pioneers. The rivalry between the various groups has no doubt had a stimulating effect all around.

The latest venture in coöperative housing is noteworthy as the first attempt to invade the Lower East Side and to triumph over its excessive land costs. Its history will be given in connection with that of the State Board of Housing, to which it especially belongs. The Amalgamated Dwellings Inc. has Mr. Kazan for its manager and profits by the experience accumulated in the Bronx. The development occupies the block bounded by Grand, Sheriff, Broome and Columbia Streets with a coverage of $60 \%$ and a spacious interior court planted and fountained after the best Park Avenue manner. The buildings are of six stories with automatic elevators. They were completed in the autumn of 1930. The architectural effect is simple and dignified. Springsteen and Goldhammer were again the architects. ${ }^{8} \quad$ Whether the population in Amalgamated Dwellings will be as homogeneous as in the Amalgamated Housing Corporation and whether it will be possible to develop in them a spirit so admirably coöperative, it is of course much too soon to predict. If leadership alone is sufficient, Mr. Kazan's presence will doubtless work the miracle.

${ }^{8}$ This development received the American Institute of Architects medal as the best apartment house built in 1930 in the New York district. 
184 Recent Trends in American Housing

The coöperative features of the Rockefeller developments, Thomas Garden Apartments and Paul Laurence Dunbar Apartments, being rather secondary, will be described later in connection with Mr. Rockefeller's contributions to the solution of the housing problem.

A coöperative housing venture for a higher economic group was initiated in 1928 and completed in 1930. A twelve-story fireproof building was erected on West 21st Street, near the Hudson River, by Consumers' Cooperative Services Inc., which has had some years' successful experience in the management of a chain of cafeterias and food shops. There are 66 apartments of from one to four rooms, and rentals are from $\$ 25$ to $\$ 35$ per room per month. ${ }^{4}$

${ }^{4}$ Monthly Labor Review, May, 1930. 


\section{CHAPTER XI}

\section{HOUSING LOANS AT LOW INTEREST}

"THE finance of home building, especially for second mortgages, is the most backward segment of our whole credit system. It is easier to borrow $85 \%$ on an automobile and repay it on the installment plan than to buy a home on that basis-and generally the house requires a higher interest rate."

So said President Hoover, in the early autumn of 1930 , to the group to whom he entrusted the planning of his projected Conference on Home Building and Home Ownership. It is a pronouncement to which disinterested students of the subject can give emphatic assent.

It is at this point and at the neighboring one of commercial profit that European systems aim to reduce the cost of housing (see Introduction, Sec. 5). The reduction of interest rate sometimes has more effect in reducing carrying charges and rentals, and therefore in determining whether a given family can afford to occupy a given house, than a reduction in capital cost (Introduction, Sec. 13). Systems which have made available a large percentage of the capital necessary for a new home, at or near a government-bond rate of interest, with amortization spread over a long term of years, have had the net effect of making it possible for families in the middle income groups to live in homes which, on a commercial basis, would only have been within the reach of families with incomes in the upper 
economic third. As was shown in Section 12 of the Introduction in some detail, our American Building and Loan Associations offer an excellent means of financing the purchase of a new home for families in the lower half of the upper economic third of our American population and sometimes make possible the purchase of an older house by families in the upper half of the middle economic third. Beyond this, in a downward direction, they do not and cannot go.

When the financial side of the acquisition of a home is being considered, the first question is how much cash can the purchaser pay down? Next, how large a first mortgage loan can he get? Then, at what interest rate, and how long does it run? If cash plus first mortgage do not cover the cost, can he get a second mortgage for the balance? What must he pay for it, and how soon must it be paid? In many places the second mortgage is very hard for a small home-buyer to secure, and it is in all places costly. Where a speculative builder accepts a second-mortgage note as part of the purchase price, he ordinarily intends to turn it into cash by selling it at a substantial discount. To protect himself from loss in this transaction, he adds a corresponding sum to the selling price of the house. Thus the homepurchaser is paying much more for his second mortgage than appears on the surface.

There is an excellent discussion of this situation in the Department of Commerce pamphlet already referred to, "Present Home Financing Methods." As the authors (John M. Gries and Thomas M. Curran) point out, home-purchasers who can supply $50 \%$ or more of the price of the home have their choice of several sound and simple ways of obtaining a first mortgage loan for the remainder. They may borrow from building and loan associations, life insurance companies, savings 
banks, trust companies, mortgage companies, or private investors. National banks, since 1927, have been permitted to invest up to one half of their savings deposits in realty loans for periods up to five years, but this is not long enough to meet the needs of most homepurchasers.

The second group of home-purchasers, having from 25 to $40 \%$ of the needed capital, are in a much less favorable position. Building and loan associations are their best friends if willing to lend on a first mortgage the 60 to $75 \%$ lacking. Otherwise the purchasers are up against a second mortgage, for none of the other agencies mentioned make such large first mortgage loans.

The Department of Commerce authors do not paint a bright picture of the prospects of the third group who can only pay down 10 to $15 \%$ of the purchase price. The only methods they describe are the excessively costly third mortgage and the excessively risky land contract system of the Middle West, where the title does not pass till the later stages of installment purchase have been reached.

The implications of this authoritative review are quite in line with the familiar "sound", disinterested business advice to the home-seeking family: "Don't try to buy until you have saved enough money to pay for all that is not covered by a first mortgage loan." Except in the few cases where employers or limited dividend companies have offered special financing facilities, there can be no doubt of the soundness of this position. Nor can it be denied that in most cases that means saving at least a third of the amount needed before attempting to build or purchase. This will be from $\$ 1000$ to $\$ 2500$ minimum according to the part of the country-perhaps an average of $\$ 1500$. It must be kept in mind that, in general, 
where building costs are low, wages and salaries are also low, and where incomes run high, so do building costs. So it cannot be said that one section of the country is strikingly better off in this respect than another. But there are certain inequalities. There is, for instance, more difference between Philadelphia and New York in the price of a small house than there is in their respective wage scales. And a climate like that of southern California, which permits building without cellars or provision for central heating, results, naturally, in lower building costs than where they must be included.

A young married couple with even one or two children and an income of $\$ 1500$ to $\$ 2500$ (according to the section of the country), or $\$ 2000$ where conditions are average, would require from 10 to 15 years, with great self-denial and no bad luck in respect to illness or unemployment, to save such a sum. In other words, the early childhood of their children, when good housing is most important, would already be past, and the more they wanted to hasten the home, the greater would be the danger of their skimping on food, doctors' bills or housing standard in the meantime (Introduction, Sec. 8 and Sec. 12).

The remedying of such a situation should be a matter of public concern. Moreover, every step toward making the acquisition of a home financially easier by lessening down-payments or interest rates or principal installments or all three, enlarges the boundaries of the class who are potential home-buyers. It is only the demand of the top economic third which has been satisfied. Millions of families would jump at the chance if home ownership were really put within their reach. The building trades would go to work again, other industries would follow in their wake and the present era of depression would be over. 
This also Mr. Hoover recognizes, as indicated in his introduction to the Home Financing pamphlet already quoted and in his instructions to the organizing committee of the Home Building and Home Ownership Conference. The American Construction Council would seem to be a logical agency to push this point of view. ${ }^{1}$

\section{Building and Loan Associations}

Progress in the direction of easier financing for lower income groups has been blocked so far by the opposition -among others - of the powerful Building and Loan Associations. As the writer believes this opposition to be due to a misapprehension which it is or ought to be possible to remove, it may be desirable to pause here for a brief consideration of these interesting organizations.

Interest rates charged by Building and Loan Associations vary from $5 \%$ in Massachusetts to cruel heights in some parts of the West. Thus, $10 \%$ is common in Texas, and the California State Building and Loan Commissioner (Report for 1927) lists societies charging as high as $12 \%$, though most of them have a rate between 8 and $9 \%$. It is hard to see on what grounds such societies can claim to be in any sense the borrower's friend. In most eastern and central states, however, the rate is $6 \%$. Perhaps the best claim of the group to be rendering superior public service lies in the fact that they frequently make larger first mortgage loans than the savings banks or insurance companiestwo thirds of the value, perhaps, as against one half. In rare cases, it may be even more. In Massachusetts $60 \%$ is the maximum loan permitted by law to the Cooperative Banks (Massachusetts name for Building and

${ }^{1}$ For reference to what they have already done, see page 282. 
Loan Associations). Practice varies in different localities and in different societies. If a house is in a locality or of an architectural type which would make it difficult to sell, it is not likely to get more than a $50 \%$ loan. The method of repayment is another point in favor of the Building and Loan societies, as it is easier for the borrower than the other American systems.

American Building and Loan Associations have just celebrated the completion of their first century of existence, the original one having been founded in Philadelphia, on the model of the already established English Building Clubs, in 1831 ("Housing of the Unskilled Wage Earner," pp. 232-234, 268, 269, 276). Varying somewhat in their organization in different parts of the country, they are in their essence groups of persons who make regular monthly savings and invest them in first ${ }^{2}$ mortgages on homes, the borrower usually being required to become a member, if not already one, and to repay what he has borrowed, with interest, by making regular monthly payments, which being placed out in loans like the rest, earn interest which helps to reduce the number of the borrower's payments. The borrower subscribes to enough shares in the Association to cancel his debt when mature. Where the interest rate is $6 \%$, a $\$ 200$ share, paid for at the rate of $\$ 1.00$ a month, instead of taking 200 months (16 years and 8 months) to mature, takes only 11 or 12 years, according to the organization's success in keeping its overhead low and its funds busy.

${ }^{2}$ A few Building and Loan Associations, especially in Pennsylvania, make second mortgage loans, but this is exceptional. Unique, in the writer's belief, is the action of the Philadelphia Housing Association in founding in 1925 the Better Housing Building and Loan Association for the purpose of making second mortgage loans to small home-purchasers without the fees, commissions, and bonuses which usually make second mortgages so burdensome. Bernard J. Newman, director of the Housing Association, is president of this subsidiary. 
Very simply organized, with very little overhead, no full-time employees, little or no rent, depending on the sagacity of their board of directors in making loans, and their first-hand acquaintance with neighbor-borrowers, protected in most states by legislation which puts their books under close supervision and auditing by state authorities, these organizations provide a safe and easy way of saving for all. They also provide an advantageous way of borrowing in comparison with other existing American methods, or permanently for the economic classes able to meet their conditions. Their growth has been phenomenal.

The Annual Report of the Secretary of the United States Building and Loan League at its convention held at Grand Rapids, Mich., July 29-31, 1930, gives the following stupendous figures:

Number of local associations ...........

Number of members ..................

Total assets

12,342

$12,111,209$

$\$ 8,695,154,220$

The Secretary estimates that the aggregate amount of mortgage loans made in 1929 was $\$ 1,800,000,000$, obviously a very round number.

The group could not have reached their present development without an enthusiastic belief in themselves and in the usefulness of their system. They have a right to be proud of what they have done and are doing. It is perfectly natural that they should view with alarm any proposal to underbid them in their own field. A responsible agency which offered to lend $90 \%$ of total cost of home, at $4 \%$ interest, over 25 or 30 years, would destroy the market for loans of $66 \% 3 \%$ of total cost at $6 \%$ interest, for about 12 years, if there were free competition between the two. It is, therefore, important that any proposed new agency should be safe-guarded 
by provisions which would limit its use to those economically unable to use the Building and Loan machinery. This is important (1) as a matter of justice to a group who deserve consideration, (2) as a matter of policy to remove the reason for their opposition, and (3) because no one source of finance could possibly supply all the loans needed for all classes of housing, and it is imperative that the new supply should go where it is needed most.

Members of the Building and Loan group quite honestly and very vociferously believe that any self-supporting American family can, with thrift, achieve home ownership through their system. They need to study distribution of income in these United States and the economic limits below which their plan ceases to function. When they have done so, the writer has faith that they will not oppose the creation of special machinery for the exclusive use of the lower income groups.

Meanwhile, in the interest of accurate information, is it too much to ask the Building and Loan League to keep precise records and to present reliable statistics in place of loose estimates, which, in the past, have been too often misunderstood even by their own members? The reform has perhaps already started, for the 1930 report does not contain the paragraph which had appeared with varying figures for years in substantially the following form (1924 Report U. S. League of Building and Loan Associations, p. 28) :

"Based on the figures obtained from states which compile the amount of mortgage loans made annually on mortgage security, it is estimated that the total amount so loaned by building associations last year aggregated one billion, two hundred and sixty million dollars against about nine hundred million dollars the year before. Assuming that the average loan made was 
about thirty-five hundred dollars, these associations financed three hundred and sixty thousand homes during the year." 3

H. F. Cellarius of Cincinnati, the veteran secretary of the League, would no doubt be the last to call the foregoing statements statistics. ${ }^{4}$ They are estimates, and, as such, legitimate enough if nothing better is available. Unfortunately, not only the newspapers and general public, but many responsible state and local officers of Building and Loan Associations all over the country, have received them and repeated them as accurate figures and as referring to new houses.

Analyzing the statement just quoted, note first that the aggregate amount of loans made during the year is an estimate based on the returns of the states which keep a record of aggregate loans. (At that date there were only 10 such states, see p. 29 of the Report cited. From the 1930 report it appears that in 1928 the number had grown to 18 and in 1929 to 24 . This is real progress.) Note next that we must assume the average loan to be about $\$ 3500$. The writer asked Mr. Cellarius on what that assumption was based and was told that three states, California, Indiana and Massachusetts, kept their records in a form which made the deduction possible. Now not all mortgage loans granted by Building and Loan Associations are on homes at all, though most of them are. If on a home, the mortgage may be granted (1) to build or buy a new home, (2) to buy an

${ }^{8}$ The statement made in July 1927 report reads: "During the past year associations loaned $\$ 1,945,000,000$ on mortgage security, which provided the means for the purchase or building of over 550,000 homes."

4 This expression may be too optimistic. In June, 1931, the writer observed in the American Section of the International Housing and Town Planning Exhibition at Berlin, a chart bearing the caption: "Number of homes financed by the Building, Savings and Loan Associations of the United States, 1901-1930." It carried the old, familiar figures, and the reader was referred to $\mathrm{Mr}$. Cellarius for further information. 
old home, (3) to repair or improve an old home already owned, (4) to raise money for some business or personal purpose on the security of an already owned home. Only in the first case is the total supply of homes being increased or the total amount of home ownership. Yet the country has been flooded yearly with statements that such and such a number of hundreds of thousands of new homes had been built since last year with the aid of the Building and Loan Associations, this figure being identical with Mr. Cellarius' hypothetical number of homes financed. ${ }^{5}$ Such a statement recently found its way into a French government report with added information as to the number of persons living in such houses. By a remarkable coincidence, the population was just five times the number of houses.

In only two states, Indiana and California, do the Building and Loan Associations keep their records so as to show what the loans are made for. Thus, the Department of Banking of Indiana, in an abstract of Reports of Condition of Building and Loan Associations for 1927 is able to give the following:

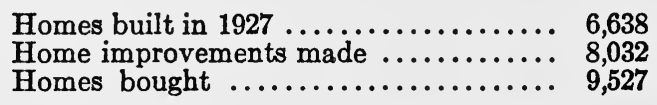

From which it may be deduced that only a little over one quarter of the loans made during that year represented new homes.

If the rest of the states would keep their records in

5 Thus, the New York Herald-Tribune of August 11, 1929, says: "Statistics made public recently by the building loan and savings associations of the United States show that in the last eight years the 13,000 thrift associations scattered through the country have financed the erection of $3,796,000$ homes, valued at $\$ 13,144,600,000$. . . It was estimated that 700,000 homes were financed last year to the value of $2,300,000,000 \ldots$ More than one-seventh of the entire population of the country is now housed in buildings financed by these associations, the number provided for being 18,965,000." 
analogous form and the national organization would report the result, a real service would be rendered.

\section{Other Lending Institutions}

The Mutual Savings Banks of the United States are tax exempt as being public utility rather than profit making organizations. They exist solely as depositories for the savings of the people. According to the "Statistical Abstract of the United States for 1928," they guarded 8 billion dollars for 11 million depositors, ${ }^{\circ}$ while Savings departments in National and State banks and Trust Companies held 18 more billions for 37 million depositors. A substantial proportion of these assets have to be kept liquid to meet withdrawal demands. Much is invested in commercial building, much goes to finance the speculative builder of homes. Comparatively little is used to finance the small home-purchaser. Here, it would seem, is an appropriate place for action. On the analogy of European practice, it might be reasonable to require Mutual Savings Banks to invest 25\% of their assets in long term mortgage loans to lowincome families purchasing a home, at or near the rate of interest paid to their depositors, which is usually $4 \%$.

As has been stated elsewhere ("Housing of the Unskilled Wage Earner," pp. 229, 266, 267, 269, 276, and "Housing Problems in America," Vol. IX, pp. 125-132, also "Proceedings National Conference of Social Work," Washington, 1923, pp. 349-352, and The American Contractor, March 8, 1924), Postal Savings deposits represent the cheapest potential source of housing loans in

${ }^{6}$ According to the president of the Bowery Savings Bank, reports of the National Association of Mutual Savings Banks showed at the close of 1930 well over $12,000,000$ depositors and assets of more than 10 billion dollars. Even in that year of depression, the gain in deposits was over $\$ 300,000,000$. 
the United States without subsidy, since they pay only $2 \%$ interest to their depositors. Their aggregate amount is not large. But their use for this purpose would make home ownership possible to an entirely new group-if it were effectively reserved for their use.

How little our banks in general have done to aid home ownership among small-income families may be inferred from the great interest manifested all over the country in a plan evolved by the Holyoke (Mass.) National Bank at the time of the housing shortage in 1920. The bank offered to make a construction loan to any approved builder for any family in Holyoke or vicinity who had had $\$ 1000$ on deposit in its savings department for six months. The lot must not be less than $50 \times 120$ or $60 \times 100$ feet in size. The house must be sewer-connected, have modern improvements and cost not less than $\$ 5000$. When the house was satisfactorily completed, the bank would help the owner get a savings bank loan for $50 \%$ of the cost of the house and lot, and lend him the remainder needed beyond his own cash at $6 \%$ interest, payments to be made weekly or monthly. There were no extras or discounts. Thus on a $\$ 5000$ house, with $\$ 1000$ cash from the owner, the first mortgage would be for $\$ 2500$ and the bank's note for $\$ 1500$. Payment of the note was expected to be made at the rate of $\$ 10$ per week and to be completed in something less than three years. Interest payments would be about $\$ 19$ per month, taxes, insurance, water and repairs $\$ 16$, or $\$ 35$ in all. But the note would call for nearly $\$ 45$ per month in addition. How many working-class families could pay $\$ 80$ a month for three years to acquire a home? ${ }^{7}$

${ }^{7}$ Figures and conditions are taken from "The Holyoke National Way of Solving the Housing Problem," by J. H. Fiefield, a 30-page booklet issued by the bank. 
The Equitable Life Assurance Company has developed a plan for combining life insurance with paying off a mortgage on a completed home by monthly installments during 10,13 , or 15 years. The life insurance feature is extremely useful, as the Belgian General Savings Bank plan has been demonstrating for more than forty years, and the length of time permitted is an advantage to many. On the other hand, the amount of the loan appears to be limited to $50 \%$ of value. The monthly charges per $\$ 1000$ loan and insurance, fifteen year plan, vary from $\$ 10.13$ at age 21 to $\$ 15.28$ at age 60. According to the company's literature, more than 50,000 home owners have used this plan during the 20 years of its operation for a total exceeding $\$ 170,000,000$.

The Land Bank of the State of New York was intended to add to the amount of capital available for financing small homes, but has had rather a disappointing history. Its bonds are not tax exempt and carry a low interest rate, so there has been no great demand for them. It has a capital of $\$ 1,000,000$ and a membership of 134 savings and loan associations (the New York name for building and loan), with bonds outstanding amounting to $\$ 14,383,000$ (Report of the State Superintendent of Banks, March 14, 1930). Its function is to issue and sell to the public bonds secured by mortgages assigned by member associations and in turn to lend a like amount to the member association. In other words, its purpose is to increase the amount of capital at the disposal of building and loan associations to lend under the usual conditions. It extends their activity among the classes they have always served. It does nothing to open up new markets.

Precisely similar would have been the effect on a national scale of the Federal Home Loan Bank bill 
which seemed for a time very likely to be enacted. Although nothing resulted from the effort, it had sufficient historical importance to be recorded.

Late in 1920, the Senate of the United States appointed a select committee, consisting of Senators Calder of New York, Edge of New Jersey and Kenyon of Iowa, "to inquire into the general building situation and to report to the Senate before December 1, 1920, such measures as may be deemed necessary to stimulate and foster the development of construction work in all its forms." A brief preliminary report was submitted about the date mentioned and a final one in March 1921. This 61-page document is of considerable interest. It admitted the seriousness of the housing shortage and its effect on health and morals, as well as the responsibility of the War for paralysing the building industry by diversion of capital and by increased costs, and hence the duty of the Federal Government in connection with its relief. It took, however, the traditional American business man's point of view that the solution must come through private business initiative and that all the Government could do was to remove a few barriers to the action of supply and demand. It dismissed the housing policies of England, France and Canada as economically unsound and predicted that if the United States followed their example, the moral ${ }^{8}$ and economic standards of the country would be lowered. "It is an insult to the ingenuity and enterprise of the American people to assume that structural and material costs can not be satisfactorily reduced. If there is anything in which the American people have confidence, ${ }^{\circ}$ it is in their own ingenuity and low-cost quantity production."

${ }^{8}$ The comparative crime records of England and the United States in the post-war years make instructive reading in this connection.

${ }^{9}$ It would be interesting to know whether these gentlemen feel that the events of the past decade have justified such a confidence. 


\section{Housing Loans at Low Interest}

The Calder Committee Report recommended ten measures embodied in ten bills. The first of these would have established "in the Department of Commerce a division for the gathering and dissemination of information as to the best construction practices and methods, technical and cost data, and matters relating to city planning and improved building practices throughout the country." The bill failed of enactment, but Mr. Hoover, then Secretary of Commerce, established the Division of Building and Housing by executive order.

The fourth measure would have amended the Federal Reserve Act "to permit the Federal Reserve Board to direct the use of savings and time deposits of National banks for long-time loans, thus giving each depositor greater security and supplying a source of long-term money for home building." The 1927 amendment of the banking laws, already referred to, was at least a step in this direction.

The fifth recommendation was "to provide for district home banks, which may sell, under federal supervision, bonds secured by the aggregate loans deposited by the member banks." This was, in effect, an endorsement of the Home Loan Bank bill, first introduced in the Senate by Mr. Calder in July 1919 (66th Congress S. 2492) and by Mr. Nolan in the House (H. R. 7597). Following the issuance of the Calder Committee Report, it was reintroduced April 13, 1921 (67th Session S. 797). This bill had its origin, apparently, in a conference between the Department of Labor and the Building and Loan Associations, ${ }^{10}$ and was obviously influenced in form by the Federal Farm Loan Act and in

${ }^{10}$ See testimony of Chas. O. Hennessy, President Franklin Society for Home Building and Savings, New York, in hearings before the Committee on Banking and Currency of the House of Representatives on H. R. 7597, Oct. 31, 1919. 
content by the statute creating the Land Bank of the State of New York.

It is regrettable, as well as rather surprising in view of its organized support, that the bill failed to pass.

\section{Government Loans for Farm Homes}

It is not generally realized that the Federal Government has actually (since 1916) provided the machinery for financing farm homes under the Federal Farm Loan Act, although there is no way of finding out just to what extent it has been used for that purpose. Authorization is contained in Section 12 of the Act, which states that loans may be made "to provide buildings and for the improvement of farm land; the term, 'improvement' to be defined by the Federal Farm Loan Board." A request for information from the Farm Loan Bureau brought a copy of the Board's rules and regulations and the assurance that farm houses were among the buildings for which loans could be made. In the annual reports, tables show the purposes for which loans have been made, but as there is no sub-division of the classification "Buildings and improvements", there is no way of ascertaining how much went for homes. The 12th Annual Report of the Federal Farm Loan Board for the year ending Dec. 31, 1928, shows that up to that date borrowers from Federal Land Banks had stated their intention of using $\$ 72,445,346$, or $5 \%$ of their borrowings, for "Buildings and improvements", (pp. 138-140) while borrowers from Joint Stock Land Banks intended to use $\$ 26,133,881$, or $3.2 \%$ of theirs, for the same purpose.

A similar situation exists in regard to the State of Oregon's Rural Credits. From 1913 a campaign was led by Dr. Hector MacPherson and others which re- 
sulted in an amendment to the state constitution ratified Nov. 7, 1916, and the necessary supplementary legislation a few months later. Article XI-a,-Rural Credits, authorized the issuance of Oregon farm credit bonds in an amount not to exceed $2 \%$ of the assessed valuation of all the property in the state, the proceeds to be available for farm loans to be made for several specified purposes which include the farm home. Loans cannot exceed $50 \%$ of the value of the farm and improvements, but may run for 36 years. Interest and amortization are covered by a $6 \%$ annual payment, whereas the loan companies charge $7 \%$ or more for interest alone. The bonds, which are tax exempt, pay $4 \%$, the margin paying costs of administration. The great need for the state system was lessened by the almost simultaneous appearance of the federal facilities. Nevertheless, loans in excess of $\$ 456,000$ had been made on May 1, 1929, according to the Oregon Blue Book for that year. There is no way of telling how much or how little of this helped to finance farm homes.

Oklahoma's Home Ownership Loan Law, 1915, amended 1917, definitely directed toward financing the farm home, was briefly described on pages 225 and 226 of the "Housing of the Unskilled Wage Earner." Repeated efforts to get the information to bring this narrative up to date, addressed to the Commissioners of the State Land Office and to other state officials have failed to elicit any response. But it appears that the law is still in operation.

South Dakota amended her constitution in 1920 to permit state credits for home building and passed what was known as the Home Builders' Act in 1921. It was to be administered by the Rural Credits Board which was carrying on a rural credit system dating from 1916 and 1917. The Board's management of rural 
credits about that time fell under investigation and proved to have involved the State in considerable loss. The housing loan plan was involved in the general wreckage and may be said to have been killed before it was born. No bonds were ever issued or loans made under the provisions of the Home Builders' Act (Chap. 254 of the Laws of 1921). The law was declared unconstitutional by the Supreme Court of South Dakota (Chapman vs. Rural Credits Board, 46 S. D. Reports, p. 72).

\section{Attempts to Secure State Loans}

The most important efforts to obtain state housing credits have been those in New York, with which the name of Governor Alfred E. Smith has been identified. The long-range recommendations of the Housing Committee of the Reconstruction Commission in 1920, including an amendment to the state constitution to permit state loans to limited-dividend housing companies, the Governor's endorsement of the program and the Legislature's lack of interest in it were briefly described in Chapter III. In the autumn of 1920, Governor Smith was defeated for reëlection, and for the two years he was out of office, the proposals of his Housing Committee slept. On his return to the governorship, an early act was to ask legislative authority to appoint a Commission of Housing and Regional Planning, to be a fact-finding and policy-recommending body. This was granted, and the Governor appointed Clarence S. Stein, the secretary of the late Housing Committee, as its chairman.

The first duty of the commission was to investigate existing housing conditions in order to give the Legislature the necessary information on which to base an 


\section{Housing Loans at Low Interest}

extension of emergency rent laws, which would come to an end without their action. This report was under date of Dec. 22, 1923 (see page 107). In the section on Conclusions and Recommendations, we find the following passages:

"In the Commission's preliminary investigation several fundamental difficulties in the solution of the housing problem have developed. One of these is the absence of sufficient capital at a low rate of interest for housing purposes. If enough private capital can not be made available for these purposes, the deficiency will have to be met by resorting to the aid of public credits.

"The State should be placed in a position to extend its credit for housing through the State Land Bank and other agencies, under wise regulation. To make this possible a constitutional amendment is necessary. It requires at least two years to secure a constitutional amendment, and for this reason the Commission recommends that steps be taken to that end at the present session of the Legislature."

This also received the Governor's strong endorsement, and the appropriate bills were introduced in both houses of the Legislature as administration measures in 1924 and again in 1925. The result was that the bill passed once in one chamber. Otherwise it failed to emerge from committee. How much of this situation was due to inherent hostility to the proposal and how much to the fact that the Republicans had a majority in both houses both years, it is impossible to say.

The third year, being advised by its distinguished counsel, Julius H. Cohen, that the State possessed authority, without constitutional amendment, to establish a Housing Loan Bank, the Commission prepared and the Governor sent to the Legislature a bill for that 


\section{Recent Trends in American Housing}

purpose (February 1926). The bank was to issue bonds and make loans on first mortgage sucurity to limited dividend housing companies to the extent of two thirds of the capital needed for their purposes, at a rate of interest dependent on the market rate of the bonds. It was believed that this would be about $4 \frac{1}{4} \%$. The other features of the bill, which were retained in the law as passed, will be discussed in Chapter XIV, but the credit and banking features were omitted entirely from the re-written bill. Undoubtedly, an honest doubt as to its constitutionality played an important part in defeating this effort for something closely approximating state credit. Inherent conservatism would have opposed it in any case. And the political situation was peculiarly unfavorable. But there was no lack of publicity or of public support. To the latter fact, is doubtless due the survival of the 1926 State Housing Act.

The Michigan campaign for a constitutional amendment to make state housing loans possible is of more recent origin. The first effort to get the necessary bill through the Legislature was in 1929. The Michigan Housing Association, which was its principal sponsor, was founded early in 1928 by Dr. S. J. Herman, who had been a student of the subject for some years. Its Board of Directors was a distinguished and representative group, including the Governor of the State, the Mayor of Detroit, and the President of the University of Michigan. The objective was to make home ownership and good living conditions possible to families with incomes of $\$ 1800$ or less, who could not achieve it by existing means. Cheap land and quantity production of garden suburbs were counted on, but abundant cheap money was also necessary. The work was to be carried on, not by limited dividend, but by absolutely non- 
profit corporations organized for the purpose. Finances were to come from regional bond issues. The resolution introduced in the Legislature read as follows: "That Section 12 of Article 10 of the Constitution of the State of Michigan, reading 'The credit of the State shall not be granted to, nor in aid of any person, association or corporation, public or private,' be amended by adding the following:- 'except that the Legislature shall have the power to enact laws to foster and finance home building and home ownership for and by citizens of lower wage or income groups as may be designated by the Legislature, may provide for the creation of home loan districts, with power to raise moneys on the credit of the district and advance said moneys to local non-profit, state-supervised housing associations on such terms as the Legislature may direct."

After a hard struggle, this resolution was adopted in the Assembly, with an amendment to this effect: "Provided that no territory in any county may be included in such district without the approval of a majority of the qualified electors of such county voting thereon." In the interests of ultimate harmony, the Michigan Housing Association decided not to continue the fight in the Senate for the time being, but to give objecting organizations time to propose something which would accomplish the same purposes and suit them better. The end of the story is still in the lap of the gods.

The unsuccessful North Dakota experiment, the partly successful Milwaukee experiment, and the wholly successful California experiment on behalf of veterans, which might, in some of their aspects, be considered here, will all be treated of in the Chapter on Housing by Public Authorities. 


\section{CHAPTER XII}

\section{ELIMINATING COMMERCIAL PROFIT}

Every dwelling, as has been said, represents, within itself, a whole series of profits. No way has been found in practice to eliminate them all. But to cut out the final entrepreneur's profit of the speculative builder and the promoter's or sales costs which accompany it, is to accomplish a good deal. This, in effect, is what limited dividend housing companies do, whether cooperative or not. It is what housing foundations do. It is also what takes place in housing by public authorities. In the last two cases, there are additional means of saving. Another category, which has only recently appeared in this country, is limited-rent housing, which may or may not be associated with limited dividends. Some employers' housing, while in effect limited dividend and limited rent, is neither legally, as the employers have not wished to tie their own hands.

Employers' housing, good, bad and indifferent, has existed in the United States since the beginning of the industrial era. ${ }^{1}$ Experiments in limited dividend housing began shortly after $18700^{2}$ A year or two previous to our entrance in the World War, a type of organization was evolved which was intended to combine the virtues and avoid the defects of both,--namely, limited dividend housing companies under the auspices of Chambers of Commerce. Housing foundations were represented in

${ }^{1}$ See Bulletin 263, U. S. Bureau of Labor Statistics, "Housing by Employers in the United States," discussed in Sec. 6, Introduction.

${ }^{2}$ See the "Housing of the Unskilled Wage Earner," Chapter IV, Model Housing in the United States. 
the pre-war United States by two almost microscopic examples and housing by public authorities was nonexistent.

The Chamber of Commerce companies proved, on the whole, disappointing. More than 150 Chamber of Commerce Housing Committees, appointed during the housing shortage period after the War, made surveys and reports advocating the immediate formation of limited dividend companies. Possibly half of these arrived at the stage of incorporating and started campaigns for stock subscriptions. Perhaps half of those which incorporated reached the point of buildingusually on a much smaller scale than at first intended. Companies which undertook a second building operation after the first was completed could probably be counted on the fingers of one hand. Among the successful few were the Chamber of Commerce housing companies established in Bridgeport, Conn., Kenosha, Wis., and Flint, Mich. A report published by the Pennsylvania Housing Association in 1925, showing the after-history of Pennsylvania organizations of this and similar types, would do equally well, with a change of names, for most of the rest of the country. Of 14 companies organized between 1917 and 1924 which actually built houses, 4 were still operating, but of the 4, 2 were only started in 1924, so had hardly had time to collapse. One company had apparently dissolved after realizing a profit of $\$ 50$ each on its houses, and 9 had been liquidated with varying degrees of loss, described in one case as "heavy" and in another as $30 \%$. Only 3 had built as many as 100 houses.

Very few of the pre-war limited dividend companies have been active since the War. One of the best of them, Mr. Schmidlapp's Model Homes Company in Cincinnati, tried, but stopped, discouraged by the high cost 
of building. The Octavia Hill Association of Philadelphia since January 1, 1917, has built 57 new houses, containing accommodations for 73 families.

The City and Suburban Homes Company of New York, dating from 1896, was the largest of the pre-war limited dividend companies. It had a paid-in capital of nearly four million dollars in 1911 and was landlord to almost 3000 families by 1917 . Its stock-holders had contented themselves, in the pre-war period, with a $4 \%$ return on their money, and in the writer's opinion a unique opportunity for public service was lost when, after the War, the dividend limit was raised to $6 \%$ Their first building venture after the War, the construction of Homewood Garden Apartments in Brooklyn in 1920, for 100 families, proved so expensive that no further new work was undertaken until 1930, when the Celtic Park property in Queens was acquired (something over two city blocks) and is being built on in a way which will yield 800 to 1000 apartments. Various properties were bought and sold during the intervening decade, but a more interesting undertaking was the rehabilitation of three run-down buildings on the Lower East Side in 1928 and 1929. The company found, to their regret, as others had before them, that the rehabilitation of railroad or dumb-bell tenements was a structural impossibility. Their experiment had, therefore, to be made on inferior specimens of the new-law tenement (built since 1901). The three houses purchased at the corner of Goerck and Houston Streets had been badly neglected for years and had never been much to boast of. Bathrooms, steam heat and hot water were installed for the first time, as well as new floors, walls and ceilings, and electric light fixtures. The 73 renovated apartments, containing from three to five rooms and bath, are modern and thoroughly habit- 


\section{Eliminating Commercial Profit}

able. Rents have a wide range corresponding to floor and outlook, the buildings being six-story walk-ups and the courts and yards no larger than the law required. The average per room per month rental is $\$ 11.62$.

This has been a useful demonstration both of what could and what could not be done in the way of renovation. Neighborhood standards will doubtless be raised and there will be some emulation on the part of near-by landlords - the more, the better. On the other hand, it is helpful to know-as the truth is always helpful in the end-that rehabilitation of old buildings offers no general economic solution of the housing problem. Although various circumstances make precise comparison impossible-such as the cost of land, tax exemption or obligation to purchase stock-it remains true that the average rent in these Goerck Street houses is higher than that in the Metropolitan houses, the Lavanburg Homes, the Brooklyn Garden Apartments, the Farband or Amalgamated Coöperatives in the Bronx and very nearly as high as that in the wonderful new Amalgamated Dwellings near by on Grand Street. It seems, therefore, to be a fair deduction that a given amount of capital would be more usefully employed in building new garden apartments under the State Housing Law, than in renovating old houses that cover $70 \%$ of their lot.

\section{The Metropolitan Life Insurance Company}

The housing work of the Metropolitan Life Insurance Company during the post-war shortage has proved of great importance, in itself and in what it has led to. It proved what could be done with good planning and large scale operation, with fairly cheap land and some years' tax exemption, on the basis of a $6 \%$ return on 
money invested. The Metropolitan undertook the demonstration at the request of the Lockwood Committee. This was the first of the limited rent undertakings. The special enabling act which permitted life insurance companies to build and rent apartments specified that they should be rented at not more than $\$ 9$ per month per room. The Metropolitan Company secured several large tracts of land, containing from one to three city blocks, in the borough of Queens, at points accessible to subway stations, but at that period only beginning to be developed. Apartments were built for 2125 families between 1922 and 1924. Andrew J. Thomas and D. Everitt Waid were the architects. The demonstration was concerned, not only with low costs and low rents, but with the introduction of definitely higher standards. The New York Tenement House Law of 1901 set $70 \%$ as the maximum coverage for interior lots and $90 \%$ for corner lots. It had been the universal practice of builders of moderate priced apartments to build to that limit. Mr. Thomas had been showing for some years on paper that by eliminating waste space in halls, by developing a whole block at a time instead of a 50 or 100 -foot frontage, by throwing all the open space together instead of cutting it up into small courts and yards, and by planting the open center of the block with grass and shrubbery, he could produce an equal number of square feet of rentable space on a much smaller land coverage, and that the renting space so secured was much more valuable because of the better light and air and the amenity conferred by growing plants. He had demonstrated the correctness of his theories on Park Avenue. The Metropolitan Life Insurance Company gave him his first chance to demonstrate it for the working man. All the garden apartment housing of subsequent date by Mr. Rockefeller or under the State 
Board of Housing, as well as that in Chicago, is lineally descended from the Metropolitan Apartments in respect to lay-out and floor plan. That the later ones are better should be a source of rejoicing, not a reason for forgetting what a big step in advance these $1922 \$ 9$-a-rooma-month apartments embodied.

The Metropolitan houses cover little more than half of the land. They are five-story walk-ups, U-shaped with the open end turned to the center of the block, all of which, together with the projections between the wings of the $\mathrm{U}$, is attractively planted with flowers, shrubs, trees and grass. Sixteen foot paved spaces between building and building, running from street to garden, provide additional light and ventilation. ${ }^{3}$

The Metropolitan houses have central heat, hot water, parquetry floors, gas ranges, electric lights, tiled bathrooms-in other words, all the usual range of modern improvements except elevators and artificial refrigeration. Apartments contain from three to five rooms, sometimes with the popular dining-bay opening from the kitchen. Monthly rents range from $\$ 27$ to $\$ 45$. The rooms in the Metropolitan apartments are often criticised as being small. In comparison with the Amalgamated rooms, they are. But they are also $\$ 2$ per room

${ }^{3}$ To protect the gardens from vandalism, it has been found necessary to enclose them with high open-wire fencing. Tenants enjoy the beautiful garden outlook from their windows. They cannot wander or sit down among the green things. Nor is any play space provided for their children. At Paul Laurence Dunbar, no fences intervene between the residents and their greenery, but there is a watchman on constant duty to see that no damage is done, and a supervised playground as well as some indoor recreational opportunities have been provided for the children. At the Amalgamated houses in the Bronx, there is neither fence nor watchman, because the cooperator-owners have imposed rules on themselves and their children which make it possible for them to live intimately among the growing things without doing them appreciable damage. At the same time, they have made remarkable provision for the children's play, indoors and out. The differences have a psychological interest in connection with tenancy and ownership. 
per month cheaper (not to mention the capital investment required by the coöperatives), and they compare favorably in size with commercially built apartments renting for double the money.

The Metropolitan experience proves it is possible, by intelligent care in selecting tenants, to keep model housing renting below market rates for the economic groups for which it was intended. There were some 10,000 applications for the 2000 apartments built. All families with incomes over $\$ 4000$ were first ruled out. Then those with children were given preference and also building trade men who had worked on the construction of the houses. The following table of occupations of tenants is taken from Mr. Stabler's pamphlet, "Comfortable Homes in New York City at $\$ 9$ a Room a Month," p. 11:

Metropolitan employees .................... 119

Managers, foremen ...................... 105

Telephone operators $. . . \ldots \ldots \ldots \ldots \ldots \ldots \ldots . .28$

Stationary engineers $\ldots \ldots \ldots \ldots \ldots \ldots \ldots \ldots \ldots \ldots, 42$

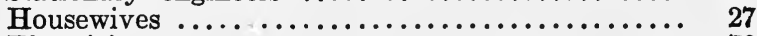

Electricians $\ldots \ldots \ldots \ldots \ldots \ldots \ldots \ldots \ldots \ldots \ldots \ldots, \quad 79$

Mechanics ............................... 69

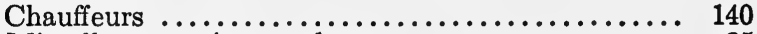

Miscellaneous city employees..$\ldots \ldots \ldots \ldots \ldots \ldots .25$

Waiters and cooks $. . \ldots \ldots \ldots \ldots \ldots \ldots \ldots \ldots \ldots, 27$

Salesmen and saleswomen $. . \ldots \ldots \ldots \ldots \ldots \ldots, 166$

Factory workers ............................ 31

Owners of business ........................ 26

Accountants, clerks and secretaries $. . . \ldots \ldots \ldots \ldots . .658$

City firemen ............................. 61

City policemen $\ldots \ldots \ldots \ldots \ldots \ldots \ldots \ldots \ldots \ldots \ldots \ldots \ldots, \quad 73$

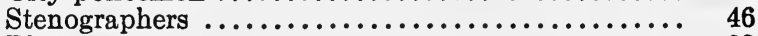

Plasterers ................................ 32

Plumbers and steamfitters .................. 48

Laborers $\ldots . \ldots \ldots \ldots \ldots \ldots \ldots \ldots \ldots \ldots \ldots \ldots \ldots \ldots, \quad 79$

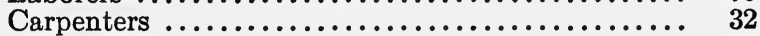

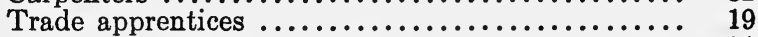

Postal employees .............................. 31

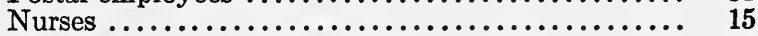

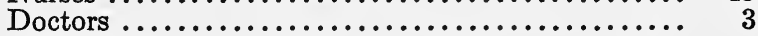

Teachers $. \ldots \ldots \ldots \ldots \ldots \ldots \ldots \ldots \ldots \ldots \ldots \ldots \ldots \ldots, 11$

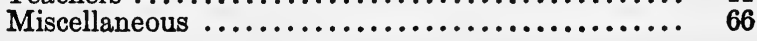


A story is told in an article descriptive of the houses in the magazine which the Metropolitan distributes to its industrial policy holders (Vol. XXIX, 9-24).

"A woman was making application for one of the \$9-aroom apartments which the Metropolitan Life Insurance Company recently completed in Queens Borough, Greater New York. She had been standing in line for nearly an hour, waiting her turn. ... 'How many children have you?' asked the agent. 'Oh dear!' exclaimed the woman, 'that's always the trouble. How many children have I? - as though it were a crime to have children. Everywhere I go they find some excuse to turn me away. I have five children.' The agent smiled at her, pulled over a chair and told her to sit down. 'Madam,' he said, 'You've come to the right place. If you had one child you would be welcome. If you had two children, you would be doubly welcome. Since you have five children, you'll have to figure out for yourself how welcome you are. All I can say is that your having five children puts your name forward on the application list so far that you are certain of getting one of the five room apartments.'"

In the type of apartment built and the type of tenant secured, the Metropolitan development has been extremely successful. Financially, it has been equally so. The total cost of the undertaking was $\$ 7,477,935$, or less than $\$ 3600$ per family. Mr. Pink's "New Day in Housing" (p. 142) gives these figures:

$\begin{array}{cccc} & \text { Gross Rental } & \text { Disbursement } & \text { Net Return } \\ 1925 & 1,041,457 & 383,199 & 658,257 \\ 1926 & 1,041,708 & 360,635 & 681,073 \\ 1927 & 1,041,209 & 363,491 & 677,717\end{array}$

Thus in 1925, the net return was $8.8 \%$. The Metropolitan allows itself $6 \%$ on the money invested and applies the balance (in this case $2.8 \%$ ) toward amortizing the principal. The 1926 return on this diminished amount was something over $9.3 \%$. This meant over $3.3 \%$ for amortization with the result that in 1927 the 
principal was reduced to $\$ 7,060,279$ and the net return was $9.59 \%$. Tax exemption comes to an end in 1932, but by that time the principal will be so much reduced that $6 \%$ interest can still be paid, and there will probably be a small margin. There are never any vacancies in the Metropolitan apartments. Mr. Stabler estimates, according to Mr. Pink, that in three and a half years, out of a rent roll of $\$ 3,500,000$, the company did not lose over $\$ 2000$.

Incomes of Metropolitan tenants run as low as $\$ 1500$. It seems to be theoretically possible, then, to house the whole middle income group in New York City in new buildings of a very satisfactory standard with a $6 \%$ return and the help of tax exemption. The Metropolitan, again according to Mr. Pink, has $\$ 12,500,000$ to invest every week. Why didn't it go on? What a dent it could have made in New York's housing problem! Not to mention the rest of the country. But it felt that building and renting houses was not the proper business of an insurance company. It made its demonstration and retired.

The Prudential Company's experiment in housing at Newark, N. J. will be discussed in the next chapter.

\section{The City Housing Corporation: Sunnyside}

The City Housing Corporation of New York was founded by Alexander M. Bing and a small group of friends in March 1924. Its dividends are limited to $6 \%$, which it has successfully paid from the start. Its first project was the building of Sunnyside Gardens in the borough of Queens on a 70-acre tract purchased from the Pennsylvania Railroad,-an avowed try-out preceding the building of a Garden City. Radburn followed in due course (Chapter IX). 
Mr. Bing's experience and sound business judgment and his generous sacrifice of time, energy and substance, have made the success of Sunnyside and Radburn possible. The technical men associated with him, Clarence S. Stein and Henry. Wright at their head, have counted for much in this success. Cheap land was the first asset, close to the Bliss Street subway station, and within 15 minutes of Grand Central Station. At the date of purchase, the site of the future Sunnyside could best be described as a dump heap.

One of the aims of the builders of Sunnyside was to prove that persons of very moderate means can afford to live in small brick homes among gardens in an accessible part of New York City. Another aim was to prove home ownership possible for these groups. A third aim was to show how much better use can be made of the interior of a block than is done in current practice. A high degree of success has been achieved at all three points.

The third aim had to be carried out subject to the limitations of the New York City layout of streets and blocks. The prescribed gridiron could not be departed from. Within the block, however, much was accomplished. The earlier blocks were developed with small houses around the periphery and the center laid out as a common park. Coverage was about $30 \%$. Tennis courts originally placed in the center of blocks have generally been moved to the community park, as have all the playgrounds for older children. Sand boxes and sometimes play equipment for the little children remain, where their mothers can keep an eye on them from the kitchen windows. In the later blocks, a series of closes have been built at right angles to the street, the houses facing on these grassy lawns instead of on the paved street. This imparts a pleasant cosiness and 
privacy and a green outlook from the front of the house. But these good things have been attained at the expense of the big central park. There are advantages in both layouts. Garages are accumulated at one place, surrounded by a not-unsightly brick wall, up which ivy is creeping. This means a longer or shorter walk to get one's car, the price Sunnysiders have to pay for their parks and gardens. Only one third of Sunnyside families, however, own cars.

The company has equipped a three-acre tract as a recreation park, with tennis courts, volley ball, basket ball, and hand ball courts, junior baseball field, separate playgrounds for small children and for older children, croquet grounds and horse-shoe pitching courts. A two-story brick building supplies comfort stations and offices downstairs and the living quarters of the supervisor above. Land, building and equipment cost $\$ 82$,000. Until June, 1928, the company shared in up-keep expense, but at that date the Sunnyside Community Association made itself responsible for future maintenance. Dues are $\$ 1.00$, per month per family, and most Sunnyside families belong. Little allotment gardens for the children are a feature of the park. Every spring, under expert supervision, the youngsters plant and cultivate the flowers or vegetables of their choice.

In addition to single-family six-room-and-bath houses, a number of two and three-family houses were built and proved popular, as the rent from the extra apartment or apartments helps the purchaser to meet his monthly payments and promises to be a permanent source of income. Two-family houses have either four or five rooms and bath on each floor. Three-family houses have a six-room-and-bath apartment for the owner downstairs and two three-room-and-bath apartments upstairs. Separate entrances assure privacy.

These houses have sold at prices ranging from $\$ 8200$, 


\section{Eliminating Commercial Profit}

the minimum for a single-family house, to $\$ 19,200$ for a three-family house. Ten per cent down payment was all that was asked for, and in some cases less was accepted. At first a single mortgage at $6 \%$ was given for the remaining $90 \%$, with 23 years, if necessary, to complete the payments. It was found that so large a first mortgage was not marketable, and for the company to hold it tied up too much of its capital. The customary two mortgages were, therefore, used, the first mortgage being sold, and the second, still at six per cent, without discounts or premiums, being held by the company. The second mortgage is paid off first in 12 to 14 years. Carrying charges, including everything but repairs and heat, for the houses built in time to secure tax exemption, run $\$ 10$ to $\$ 11$ per room per month. Those with the two and three-family houses receive enough in rent to make the net charges on their own quarters much less. The apartments were in great demand, so that, as a rule, the company secured the tenants before selling the house. This made it possible to standardize rents as well as assuring the purchaser against loss through vacancy.

In addition to the small houses, the company built during its first two years the coöperative apartments already referred to. Later it built three larger apartment groups, Hamilton, Monroe and Wilson Courts, of which it retains ownership. The first two are built around large central gardens. Its apartments net the company 7\%, which helps to maintain the even keel. Two-year leases are offered at a lower rate than one, and three-year leases lower still. The company saves enough on redecorating to make up for it, and an inducement is offered the tenant to check his restless city habit of yearly moving. Thus a five-room apartment which rents for $\$ 79$ a month on a one-year lease, is reduced to $\$ 74$ on a two-year and $\$ 67$ on a three-year 


\section{Recent Trends in American Housing}

lease. A four-room apartment which is $\$ 70$ a month for a year is only $\$ 60$ for three years.

In 1924 homes (houses or apartments) were built for 128 families

In 1925

In 1926

In 1927

In 1928 for 227 families for 295 families for 357 families for 224 families

TOTAL $=1231$

The total value of residential buildings was $\$ 8,117$, 606. Sunnyside is commonly spoken of as a ten-million dollar development, that sum including the cost of the land and some $\$ 496,000$ for stores, garages and park. On December 31, 1928, the building of Sunnyside being complete, capital stock was $\$ 2,394,300$ and surplus $\$ 325,522$ (Fifth Annual Report). It will be observed that the cost per family is more than twice as great as that in the Metropolitan development. Against which, it will be recalled that Sunnyside rooms are larger, the number of rooms per family greater, and the coverage of land by buildings much less.

The Fourth Annual Report (1928) gives information on occupations gleaned from property owners at Sunnyside. It is not given for tenants.

Mechanics ................................... 116

Office Workers ............................. 79

Tradesmen and owners of small business ........ 55

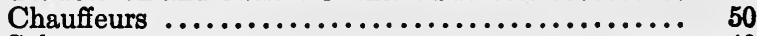

Salesmen $. . . \ldots \ldots \ldots \ldots \ldots \ldots \ldots \ldots \ldots \ldots \ldots, \quad 49$

Federal, State and Municipal employees ........... 35

Restaurant workers ........................ 18

Domestic servants ........................ 12

Housewives .............................. 16

Social workers $. . \ldots \ldots \ldots \ldots \ldots \ldots \ldots \ldots \ldots \ldots, \ldots, 16$

Teachers ............................... 24

Architects, draftsmen and engineers ............ 14

Doctors and dentists ........................ 7

Miscellaneous occupations .................... 24

Miscellaneous professions including

actors, artists, trained nurses ................. 38

No information $\ldots \ldots \ldots \ldots \ldots \ldots \ldots \ldots \ldots, 11$ 
The trend is somewhat more toward business and the professions than in the Metropolitan apartments. But Sunnyside, with its approximately 5000 inhabitants, represents a fair cross section of the population, with both extremes omitted.

Concerning income, the Fourth Annual Report states that the "average wage" of purchasers of Sunnyside houses is about $\$ 200$ per month and that listed incomes range from $\$ 125$ per month to $\$ 800$, the higher ones usually representing the earnings of two or more members of the family. The Third Annual Report, dealing with a smaller number (387) says that almost 50\% of the families are in the income group below $\$ 3100$ and that the next largest group, about $35 \%$, fall between $\$ 3000$ and $\$ 4000 .^{4}$ That $\$ 200$ per month should almost certainly be interpreted as meaning median income of the head of the family. If to that, we add the $\$ 500$ per year, by which the Sunnyside Community Association found in its 1929 census the average family income exceeded that of the head of the household, we shall find little conflict between the two reports. ${ }^{5}$

1 The details are as follows:

Families with incomes from $\$ 1500-2000$

$2100-3000$

$3100-4000$

$4100-4500$

28

${ }^{5}$ A census taken by the Community Association and published in the Sunnyside News of September 1929 is interesting as giving tenants' incomes in addition to owners' and showing the former run slightly lower. Income of Head of Household-Year 1928.

Owners

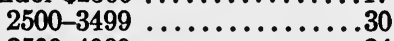

$3500-4999$..............24

5000 and over $\ldots \ldots \ldots \ldots .29$

100
Tenants

$23 \%$

37

30

$\frac{10}{100}$

Income figures were secured from a little over one third of all Sunnyside families, so their being somewhat higher than the companies may only show that those with high incomes would be more likely to give them than those with low. 
Maintenance of the center of the blocks for common use is provided for by a 40-year easement. After 40 years, if the owners wish to put up fences and have individual back yards, they may. But it is hoped that by that time they will not care to. Maintenance of the central park in the meantime is in the hands of four trustees for each block. Two are appointed by the company and two elected by the residents. Block maintenance charge is included in monthly payments, amounting to $\$ 3$ in the case of a single-family house. Each family has also a small space of its own for flowers, and there has been a healthy rivalry among Garden Club members and an annual awarding of prizes.

Various activities have sprung up in the community. In 1929 the Sunnyside Play House carried off the second prize in the National Little Theater competition. Two years before a group from Welwyn Garden City had taken first prize. A modern nursery school was started in the early days by a group of mothers and put in charge of one of them who had had kindergarten training. It has grown into a model school under the guidance of Professor Patty Smith Hill of Teachers' College, with a staff of four teachers and pupils from 18 months to seven years. The school occupies quarters over the company's office, and the roof furnishes their playground.

This account of Sunnyside cannot be closed without quoting Mr. Bing's wise suggestion that if American philanthropists would acquire the habit of making their princely gifts to universities, churches or hospitals in the form of limited dividend housing company securities, they would be making their money perform a double service. That surely ought to appeal to the American efficiency instinct. The difficulty in securing capital has always been the stumbling block in the expansion 
of limited dividend companies. It is easier to secure outright gifts for a good cause than $6 \%$ investments which seem to fall psychologically between the stools of business and philanthropy. Foreign nations have broken the deadlock by government loans or government controlled loans. If Mr. Bing can induce American private capital to adopt the double-use plan on a large scale, perhaps those Americans who insist we have no need of government action, can prove their point. It is gratifying to learn that the Russell Sage Foundation and others have bought blocks of City Housing Corporations stock. But the main thesis is still to be proved.

\section{The Rockefeller Houses}

The interest in housing manifested by John D. Rockefeller Jr. has been a welcome phenomenon of the postwar years, - the more so as the subject had so curiously failed to attract our men of wealth in the past. Mr. Rockefeller's approach has been cautious and exceedingly quiet. He plays a lone hand and would seem to be working out his problems from the bottom without much reference to the rest of the world. He shuns publicity and lets his results speak for themselves. $\mathrm{He}$ evidently believes in Andrew J. Thomas and disbelieves in tax exemption.

The first venture was at Bayonne, N. J., where a Chamber of Commerce limited dividend housing project launched in 1919 had been held up by lack of stock subscriptions. In $1924 \mathrm{Mr}$. Thomas was secured as architect and Mr. Rockefeller supplied the funds. Architectually, Mr. Thomas is seen at his best in this development, which is characterized by dignity, simplicity and fine proportions. The buildings are only four stories in height and cover but $36 \%$ of the land. 
Socially and economically, the development has been less successful. If it was, as currently supposed, intended for the rank and file of Standard Oil workers, it failed to reach them. It has certainly provided excellent homes for the somewhat higher income families who were eventually accepted as tenants. It is generally understood that the development has not paid the 5 or $6 \%$ dividends anticipated.

The buildings contain 149 apartments of four rooms and $a$ bath, five rooms and $a$ bath, and six rooms and two baths. The last represent a pet idea of Mr. Thomas'sand in the writer's opinion a mistaken one. Mr. Thomas argues the tenants will take lodgers to help pay the rent and that the consequences will be less unfortunate if the lodgers have a room and private bath somewhat separate from the family quarters. The writer maintains that a model housing development can and should prevent the taking of lodgers, and that the two-bath plan makes rents so high as to force tenants to take lodgers, who would have no need to do so in a smaller apartment at lower rental. Rents are $\$ 9$ per room per month on the top floor, $\$ 10$ and $\$ 10.25$ lower down.

The next undertaking of Mr. Rockefeller and Mr. Thomas seems to have been successful in reaching the class intended and in bringing the expected financial return. But the class was an easier one to reach. The apartments built are on Avenue A and 65th Street, New York, overlooking the East River. They are near the Rockefeller Institute and are largely, though not exclusively, tenanted by its employees. The building covers $56 \%$ of the land and contains 82 apartments renting at from $\$ 12$ to $\$ 15$ per room. According to Mr. Pink, it pays $61 / 4 \%$ on the investment.

The third experiment was the least happy of them all from any point of view. The Thomas Garden Apart- 
ments, named in compliment to the architect, were built in 1926 on Mott Avenue, between 158th and 159th Street, Bronx, facing on Franz Sigel Park. The land had been bought by members of the International Ladies Garment Workers Union for a coöperative, but they found themselves unable to raise the necessary capital, and asked Mr. Rockefeller to take it off their hands. If, as is commonly supposed, he built with this group in view, he did not reach them. Esthetically, the effect is over-ornate. On the economic side, the apartments proved difficult to dispose of. Large sums were spent in advertising. Concessions were made as to down payments. In the summer of 1930, the carrying charges per room had to be increased $\$ 2.50$ per month. Tenantowners, rebellious at first, finally agreed.

The plan called for $100 \%$ coöperative ownership, tenant-owners subscribing to stock equal to the capital value of their apartments. Mr. Rockefeller turned over the development at cost, asking $6 \%$ interest on his money while tied up. Until the preferred stock is retired, which is expected to take place in 15 years, management is in the hands of Mr. Rockefeller's representatives, although there is meanwhile an Advisory Board of Tenant Subscribers who will be ultimately merged into the Board of Directors. Payment for stock is to be completed in 25 years. It was intended that there should be at the beginning a cash subscription to stock of from $\$ 1000$ to $\$ 1700$. This requirement is understood to have been considerably relaxed. The cost of land and buildings was $\$ 1,400,000$. Accommodations were provided for 175 families-an average of $\$ 8000$ per family,-obviously beyond the means of the Ladies Garment Workers. Individual apartments were priced from $\$ 6000$ for the cheapest 4 rooms and bath to $\$ 9700$ for 6 rooms, 2 baths and a sun parlor. Carry- 
ing charges ran from $\$ 64$ to $\$ 100$ per month. More than half of these payments represent installment on stock subscription and interest. Full particulars are given in a 22-page prospectus issued by Thomas Garden Apartments, Inc. Mr. Pink suggests that Bronx tenants demand automatic elevators and fewer rooms. His points are well taken, but the writer would add to the list of handicaps the psychological effect produced by Mr. Thomas' terra cotta stork bearing a baby in a napkin suspended from its beak, which hovers over the main entrance.

The fourth and largest of Mr. Rockefeller's contributions toward the solution of the housing problem is by far the most successful and the most socially useful. Paul Laurence Dunbar Apartments for Negro families in Harlem is the first recent attempt to meet a need so great as almost to beggar description. On the one hand, Negroes receive lower wages than whites, and on the other, they pay higher rents for worse homes. Even well-to-do Negroes have difficulty in securing comfortable homes. In a 1928 study of 1014 families in various parts of the city conducted by the United Neighborhood Houses and the League of Mothers' Clubs, the West Harlem Negro families were found to average $17 \%$ lower in income than the white workers elsewhere and to be paying an average rent nearly $\$ 3$ per room per month higher. They were paying almost one third of their income for rent against one fifth for the white families. Harlem is badly overcrowded. Its houses, originally built for white tenants, have in most cases suffered from lack of repairs and in many cases from being divided to squeeze in more families. Many years ago, in 1904 and 1911, the City and Suburban Homes Company built two apartment houses for Negro tenants on West 62nd and West 63rd Streets, with ac- 


\section{Eliminating Commercial Profit}

commodations for 173 families. Otherwise, nothing had ever been done for them in New York City.

Mr. Rockefeller's advent in this field was most welcome. His site comprises the city block between Seventh and Eighth Avenues, 149th and 150th Streets, just south of the Harlem River. The need for economy held Mr. Thomas to the straight lines and well proportioned masses in which he excels, and though it also required six stories and a 50\% coverage, the central gardens are so well planned that the effect is one of spaciousness. The New York Chapter of the American Institute of Architects awarded to the Paul Laurence Dunbar its first prize for apartment houses built in 1927. Entrances to stair halls are from the garden instead of the street. Access to the garden is through a series of arches giving a glimpse of green which looks like a bit of paradise from the parched street outside. Dividing the gardens in two, a supervised playground for children occupies the center of the block. In the basement adjoining it are a day nursery and after-school club rooms for the older children-a boon to mothers who must work away from home. Much is done for the children's health and wholesome recreation. An exceedingly useful service is the Vocational Placement Bureau. The rental of stores on Seventh and Eighth Avenues helps to reduce expenses. Learning of the lack of banking facilities in Harlem, Mr. Rockefeller established a bank in one of these sites with Negro employees and a mixed directorate.

The system at Paul Laurence Dunbar is one of ultimate coöperative ownership, as at Thomas Garden Apartments. The prospects of success are, however, much brighter; (1) because race constitutes among $\mathrm{Ne}$ groes a really strong bond of union, while the residents of Thomas Garden Apartments are hopelessly heteroge- 
neous; (2) because the housing difficulties of Negroes have been so overwhelming as to make them deeply appreciative of any opportunity for better things; (3) because for twenty years the management is in Rockefeller hands; and (4) because Mr. Rockefeller's representatives in this management are two exceptionally well qualified members of the Negro race, professionally trained and socially minded,-Mr. and Mrs. Roscoe Conkling Bruce.

The total number of apartments is 511 . The number of rooms ranges from three to seven, with many apartments having dining bays, counted as half a room. The total number of rooms is about 2400 . The total cost of land and buildings has been put at $\$ 3,300,000$. This means a per-family average of $\$ 6500$ or a per-room cost of $\$ 1375$. There were between 7000 and 8000 applications for the apartments. Many were turned down on the score of character. The sporting and criminal element was not wanted. Many deserving families had to be refused on account of their obviously inadequate incomes. Mr. Rockefeller reduced the return on his money to $51 / 2 \%$ and the down payments for stock to $\$ 50$ per room. The carrying charges on this basis vary from $\$ 11.50$ to $\$ 17.50$ per month per room, according to floor and outlook, with an average of $\$ 14.50$. The purchase of stock on this basis was expected to require nearly 30 years, but economies effected in management give promise of reducing the time to nearer $20 .^{\circ}$ The apartments were opened in February 1928 and $100 \%$ occupied in May.

The rather frequently heard criticism that the Dunbar Apartments are occupied exclusively by well-to-do families-the "aristocracy of Harlem"-is met by Mr. Bruce's summary of occupations and incomes in a re-

- Twenty-three years is the present estimate. 

cent brochure on "The Paul Laurence Dunbar Apartments of New York." Mr. Bruce gives the occupations of 336 out of his 511 heads of families-all in which 10 or more persons were engaged. Among these, 13 teachers represent the only professional group. The largest group is made up of 72 post-office clerks, and there are 12 letter-carriers. Domestic service is credited with 58 . There are 22 chauffeurs, 15 dressmakers, 10 unskilled laborers, 18 stenographers, etc. Of the 465 tenantowners for whom Mr. Bruce had exact figures, one half were receiving less than $\$ 148.86$ per month. We may, therefore, put the median income at $\$ 1800$ a year. The lowest quartile, according to Mr. Bruce, received not-toexceed $\$ 122$ per month, which is a trifle under $\$ 1500$ a year, and the highest quartile $\$ 177$ or more ( $\$ 2124$ ). This shows decidedly lower income grouping than in any of the post-war developments for white families, except Lavanburg Homes, although the charges involved are higher than in a number of them. It was believed that a sprinkling of successful and distinguished members of the Negro race in this community of about 2000 persons would have a stimulating effect on the racial pride and personal ambition of the others. There is much to be said in favor of such an idea.

Mr. Rockefeller has an indisputable right to object to tax exemption so much that he will not let his housing developments benefit by it, and $\mathrm{Mr}$. Bruce has an equally undoubted right to agree with Mr. Rockefeller. But when, in the brochure already quoted, under the heading "Our Community too Self-Respecting to Desire Tax Exemption," Mr. Bruce states that "The Dunbar coöperative community rejoices that it has not been called upon to sacrifice its own civic selfrespect by foisting upon others its due proportion of the burden of taxation," one may be pardoned for a 
certain amount of skepticism as to the extent of the rejoicing.

\section{Lavanburg Homes}

The Fred L. Lavanburg Foundation is of especial interest as the only housing foundation in the United States." Mr. Pink in his "New Day in Housing," dismisses the Lavanburg Homes as "charity tenements" and therefore without social significance. This is hardly fair to self-respecting tenants who are paying from $\$ 7.50$ to $\$ 10.50$ per week for their apartments,as much as they or their neighbors have ever paid, though of course they are getting far more for their money. Those of us struggling to meet the term bills of our children in college hardly feel that they are attending "charity schools" even though the colleges are endowed institutions and we are frequently informed that tuition charges do not more than half cover actual costs.

No one is likely to suggest that the housing problem can be solved by housing foundations alone. On the other hand the services of foundations in setting standards and in making demonstrations have been noteworthy. Without going back to the somewhat ancient history of the London housing foundations, it would be hard to deny the world-wide influence of Mr. Cadbury's Bournville, the product of a foundation, on twentieth century housing and town-planning. Not so familiar in this country, but equally certain, is the influence on recent Parisian housing of the standards set by the Lebaudy and Rothschild foundations established twenty to thirty years ago.

7 The small Boston and St. Louis foundations cited in "The Housing of the Unskilled Wage Earner" have since been turned to other uses, in accordance with the terms of their endowments. But see pp. 251, 252. 
Mr. Lavanburg unfortunately died before the Lavanburg Homes were quite ready for occupancy, so that he did not have the satisfaction of seeing the happiness of the 110 families (about 550 persons) who live there.

The foundation was incorporated in March 1927, and three months later building was under way. The site chosen was on Goerck Street, in the heart of the Ghetto, two blocks from East River and a block south of Houston Street. The plot is 210 feet long by 100 deep. The buildings erected are six stories high and form a great $\mathrm{E}$ with the long line at the rear and the two big open courts facing the street. The courts are paved instead of planted, which at that date on the Lower East Side was probably inevitable. The apartments are excellent, well lighted, and aired, with all the usual modern improvements. The exterior makes no claim to beauty, but is not lacking in dignity.

The tenants moved in during January 1928. Their selection had raised many problems. There were over 2000 applications, 850 of which were considered promising enough to receive visits to their homes. A study of 930 rejected applications shows the following reasons for rejection-sometimes more than one in a given case. $^{8}$

High income ......................... 535

Low standard of living $\ldots \ldots \ldots \ldots \ldots \ldots \ldots \ldots, \quad 90$

No children $\ldots \ldots \ldots \ldots \ldots \ldots \ldots \ldots \ldots \ldots \ldots, \quad 91$

Grown up children $\ldots \ldots \ldots \ldots \ldots \ldots \ldots \ldots \ldots \ldots, 137$

Miscellaneous (living in modern

buildings, seeking boarders, etc.) .......... 71

In other words, all tenants were selected from families with young children, whose income did not permit them to rent modern apartments at current commercial prices, and whose standard of cleanliness in their former homes gave promise of their profiting by good surroundings.

${ }^{8}$ First Annual Report, Fred. L. Lavanburg Foundation, 1929. 
Character references were carefully checked up. The income limitations were not hard and fast, but varied with the number and age of children, being based on the budget allowances of the Jewish Social Service Association.

The newspapers of the time repeated ad nauseam that Mr. Lavanburg had built for families with incomes of $\$ 25$ per week or less, but had found to his surprise that there were no such families in New York. This yarn fitted into the prosperity picture of the period, but was wholly apocryphal. It is, I believe, true that Mr. Lavanburg had hoped to be able to rent at $\$ 5$ or $\$ 6$ per month per room, to meet the needs of the lowest income groups, but when he studied land and building costs, found it impossible,- -which is quite a different thing. The rents charged are:

$\$ 7.50$ per week for 3 rooms and a bath

8.50 per week for 4 rooms and a bath

10.50 per week for 5 rooms and a bath

with 25 cents less on the fifth floor and 50 cents less on the sixth. Per-room-per-month rent is thus seen to lie between $\$ 8.57$ in four and five room apartments on the top floor and $\$ 10.71$ in three-room apartments on the lower floors. The foundation does not, so far, receive tax exemption. The aim is to cover upkeep and expenses with something laid by for depreciation. Just what this last item will amount to can hardly be determined for several years.

Nine of the Lavanburg tenants are in receipt of allowances from philanthropic or government agencieschiefly mothers' pensions. The incomes of the others are classified as follows:

13 tenants earn $\$ 25$ to $\$ 30$ per week

38 tenants earn 30 to 35 per week

32 tenants earn 35 to 40 per week

10 tenants earn 40 to 45 per week

5 tenants earn over 45 per week 
From which it may be deduced that $65 \%$ of the families have incomes between $\$ 30$ and $\$ 40$ per week, or between $\$ 1500$ and $\$ 2000$ per year, $21 \%$ have incomes under $\$ 1500$ and $14 \%$ have over $\$ 2000$. An attempt to compare Lavanburg and Dunbar incomes would show the Lavanburg median slightly lower, the highest quartile of the Dunbar entirely missing at Lavanburg and the lowest quartile somewhat lower at Dunbar than at Lavanburg. The higher proportion of children at Lavanburg lessens the significance of the comparison.

Lavanburg tenants, with few exceptions, were already East Side residents and had been paying from $\$ 15$ to $\$ 25$ per month for three or four rooms in old-law tenements. In regard to occupation, the largest group (21) are cloak operatives, the next largest (9) peddlers. Then we have taxi drivers, truck drivers, shipping clerks, street cleaners, sales clerks, barbers, bookbinders, city laborers, and a large list of trades with one or two in each.

The cost of land in this development was $\$ 164,494.82$, or $\$ 7.42$ per square foot. The cost of the buildings was $\$ 528,045.49$, a total of $\$ 629,540$, or $\$ 6400$ per family. Annual rent receipts are approximately $\$ 46,000$, which is less than $62 / 3 \%$ gross return on capital cost.

A large share of credit for the success of the first years and for the fine community spirit developed by the tenants belongs to the supervisor, Abraham Goldfeld, whose work calls for tact, patience and executive ability of a high order. Everything remotely savoring of paternalism or institutionalism has been avoided. Tenants who do not care to take part in community activities have their wishes respected. The management stands ready to coöperate with those desiring to organize, but has had rather to restrain them from scattering their energies too widely than to stimulate them to start things. The roof has been enclosed with wire and made a safe 
place for mothers with babies and for playing children. On summer evenings, it is used by all the family. Movies and other entertainments are frequently given there. The basement has been gradually fitted up, in response to demand, with club rooms, for boys, girls and adults, a game room and a library. The Board of Education has carried on a Summer School there and during the winter an English class for mothers. There is a dramatic group known as the Lavanburg Players. There is a Nature-Study Club for boys, who gratify their collecting instinct by stocking the shelves of their "Museum" with specimens gathered on hikes.

There were no changes in tenancy at the end of the first year, and all rents had been promptly paid. Loss from vacancies may obviously be omitted from calculations.

As to the extra-mural influence of Lavanburg Homes, the writer was struck within a few months of their opening by the effect on neighboring landlords. Up and down Goerck Street signs were displayed on old houses: - "Baths and electric lights being installed. Ready for occupancy such and such a date," or, "This house is being modernized and redecorated. Steam heat. Gas for cooking." No such activity was visible in adjacent streets. The neighborhood was looking up.

Mr. Lavanburg made the Foundation his residuary legatee. When the estate is settled, there is expected to be enough for another housing experiment,- approximately $\$ 1,150,000$. Meanwhile, there is to be a tryout in renovating an old-law tenement. In March 1931, the Foundation acquired title to a five-story building on the corner of Goerck and Broome Streets, which, modernized, will contain 16 three-room-and-bath apartments. 


\section{Chicago}

When Mayor Dever of Chicago appointed the wellloved head of the University of Chicago Settlement, Mary E. McDowell, as Director of the city's Department of Public Welfare, it was expected that something would be done for better housing. The first step was a survey by Elizabeth A. Hughes, to which reference was made in the Introduction, Sec. 6, of the "Living Conditions of Small Wage Earners in Chicago," with especial reference to Negroes and Mexicans (1925). There had been a large Negro migration to Chicago from the South during and following the World War. One-twentieth of the population in 1925 was estimated to be Negro. The Mexican group was small-only 1141 in 1920, but estimated five years later at 8000 .

The survey showed the housing of Mexicans as worse than that of Negroes, and the housing of Negroes as worse than that of any other population group. A table showing earnings of 1244 families is interesting to compare with the New York study by the United Neighborhood Houses. Ten per cent had incomes from $\$ 200$ per month up. The class from $\$ 125$ to, but not including, $\$ 200$ accounted for $14 \%$. That leaves $76 \%$ with incomes of less than $\$ 125$ per month. The table further shows that $47 \%$ had less than $\$ 100$ per month and $33 \%$ had less than $\$ 80$.

The familiar story of overcrowding, dilapidation, insanitary toilets, insufficient light and air, lack of modern conveniences, is quietly told, with pictures and figures allowed, for the most part, to speak for themselves. The few generalizations are the fruit of much experience.

"It is no solution of the problem of housing wageearning families to let them have the almost worn out, 
sloughed-off houses of other groups which have prospered enough economically to seek new and more desirable places of residence. And yet how pitifully few are the examples in this country of earnest, intelligent search for any other way of meeting the need of working families for decent homes." (p. 29)

Miss McDowell in her foreword appeals to the civic pride of Chicago to grapple earnestly with the problem, vast as it is. In the conclusion, she recommends limited dividend companies as probably offering the best solution, but wisely calls attention to the need of "some program for retiring worn-out houses" at the same time new ones are being built.

An all-day conference of prominent citizens was called to consider this report and take action on it (April 16, 1926). In response to the request of this group, the Mayor appointed a City Housing Commission. The general principle of limited dividend housing, on a very large scale, in several different centers, was agreed upon. Some changes in legislation were desired and, I believe, in due course secured.

Two large developments have so far resulted, neither of which can be said to reach below the middle group of incomes- the Marshall Field Estate houses for white families and the Julius Rosenwald houses for Negroes.

The Marshall Field Garden Apartment Homes, completed April 1, 1929, occupy two city blocks on the North side, between Hudson Avenue, Blackhawk, Sedgwick and Sigel Streets. The site was previously occupied by substandard housing which it was an advantage to be rid of. There are 627 apartments of from three and one half to six rooms $(2,908$ in all) and 20 stores. Rents range from $\$ 12$ to $\$ 15$ per room per month, the average being $\$ 13.55$.

The cost of the land was $\$ 1,211,834$ and the build- 
ings and heating plant $\$ 4,467,166$, a total of $\$ 5,679,000$, approximately $\$ 9000$ per family or $\$ 1900$ per room. There is no limited dividend company here in the legal sense, but the practical result is much the same. The gross returns would seem to be less than $81 / 2 \%$ if there were no vacancies. But vacancies are said to have been a problem from the start, due to the undesirable neighborhood, rents being beyond the reach of families already in bad neighborhoods. Chicago has no tax exemption.

Mr. Rosenwald's contribution, as described by his son-in-law, Alfred K. Stern, director of the Julius Rosenwald Fund, in the March 1929 number of The American City, seems to have been undertaken with the idea of catering only to the well-to-do among Negroes in the hope of proving it to be profitable, and thereby stimulating private business enterprise to come into the field. The development occupies an entire city block on the South Side, between Michigan and Wabash Avenues, 46 th and 47th Streets,- - six-acre site. Coverage is only $40 \%$. The buildings are of five stories and contain 421 apartments with 1641 rooms. The center of the block is landscaped. Electric refrigerators are included in the equipment. The entire cost of the project is approximately $\$ 2,700,000$, or a trifle over $\$ 6400$ per family, or $\$ 1645$ per room. Rents are intended to be "moderate, not low" and to produce a $6 \%$ return or better. This also, then, is not in the legal sense a limited dividend enterprise. Rents run from a minimum three-room apartment rental of $\$ 45$ to a maximum five-room rental at $\$ 85$. Automatic electric refrigeration adds $\$ 1$ more. The average rate per room per month is $\$ 16$. Construction was completed late in 1929.

According to an article by the manager of the Michi- 
gan Boulevard Garden Apartments, Robert R. Taylor, in the March 1931 number of Opportunity, the apartments were $97.5 \%$ occupied during 1930 , and losses from bad debts amounted only to $1.1 \%$ of rentals. There was a net return on the equity at the end of the year of $5.6 \%$, the interest paid on the mortgage being $5.5 \%$.

Mr. Taylor says $\$ 2400$ is approximately the average family income of the tenants. He adds that families with much less cannot afford to live in the apartments. There are two nursery schools, a playground, community rooms, a roof garden, and an active Tenants' Organization.

In a letter to the writer dated March 4, 1931, Mr. Stern says that so far as he knows there is no plan afoot to build at lower rentals for Chicago Negroes. 


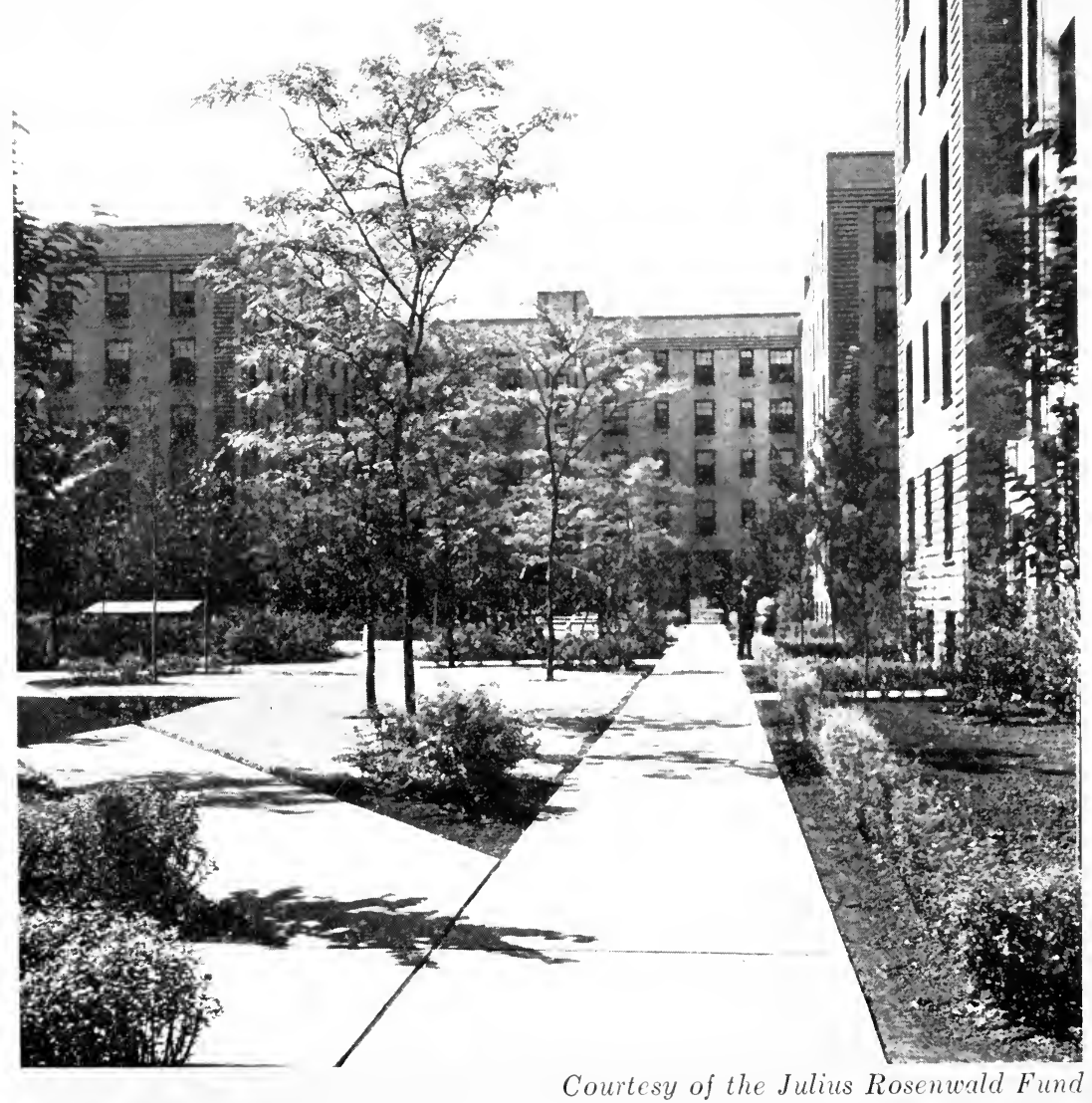

Michigan Boulevard Garden Apartments, Chicago. 



\section{CHAPTER XIII}

\section{HOUSING BY PUBLIC AUTHORITIES}

Most Americans would probably assert that no such thing exists in this country. But they would be wrong. Some of the items on the following list represent projects that were never carried out. Some represent developments too small to have any great importance. But the list includes undertakings of real potential significance and-for the United States-of substantial extent.

\section{Housing by National Authorities}

In the interest of chronology, the National Government's War Housing has already been described (Chapter I). Topically, it belongs here. However exceptional it may have been in origin and purpose, it existed -and on a fairly large scale. Its history has been a creditable one and its influence socially useful. Had it lasted longer, it would have been more so.

The one fragment of the Government's war housing which survives in government ownership and management was mentioned in Chapter III,- the hostels for women clerks of the federal departments in Washington. The facts that they meet an urgent need and that they cost the tax-payers nothing were mentioned. Being in temporary structures on land destined ultimately for public buildings, they cannot be continued indefinitely,-unless the Government has a change of heart.

A bill now before Congress would intrust a new piece 
of work to the United States Housing Corporation. Its purpose is the elimination of Washington's alley slums. Further particulars will be found in Chapter XV.

It should be recorded here that the National Government does and always has provided housing at its military and naval stations for officers and enlisted personnel of the army, navy and marine corps. It houses civil as well as military employees at the Isthmus of Panama and, to a less extent, in other outlying territory. It has recently begun to acquire homes for ambassadors and others in its diplomatic service. It cannot be said that there is any wide social significance in all this, or any indication of a change in policy toward the homes of the people in general. It is simply a fact.

\section{The State of Massachusetts}

The attitude of the orthodox toward the Massachusetts demonstration of state housing has always been that of Midshipman Easy's nurse in the matter of her baby. It ought not to count because "It was such a little one". Its small size does indeed indicate that the blocking forces were stronger than the backing forces. In itself, it has been in no sense a failure, but it is legitimate enough to claim that the lack of follow-up has made it a failure so far as its larger purposes are concerned. A fairly full account of the Massachusetts Homestead Commission will be found in the Sixth Chapter of the "Housing of the Unskilled Wage Earner." Suffice it here to say that under the leadership of Henry Sterling, Union Labor had secured an amendment to the state constitution in the fall of 1915 permitting the Legislature to authorize the Commonwealth "to take land and to hold, improve, subdivide, build upon and sell the same for the purpose of relieving congestion of population and providing homes for citizens; provided, 
however, that this amendment shall not be deemed to authorize the sale of such land or buildings at less than the cost thereof." In 1916 the Homestead Commission asked the Legislature for a $\$ 100,000$ appropriation to conduct a demonstration in suburban housing. In 1917 the Legislature gave it $\$ 50,000$ for its purpose. By that time the cost of building had so greatly increased that the small appropriation produced only a dozen four and five-room-and-bath houses on a seven-acre tract in the outskirts of Lowell. They were promptly sold and are being paid for according to plan.

Meanwhile the Labor group had transferred its main interest to municipal housing, which the 1915 amendment had been originally intended to include, but, as passed, did not. In 1917 they secured the inclusion of the phrase and the providing of shelter in a constitutional amendment authorizing cities and towns, as well as the State, to provide food and other common necessaries of life "during time of war, public exigency, emergency or distress." The untimely death of Henry Sterling and certain adverse legal opinions as to the housing shortage constituting an emergency are probably the reasons why this promising Massachusetts movement has had no sequel.

\section{State of Louisiana}

The State Legislature passed a resolution (Laws of 1918-Extra Session-No. 13) creating a State Housing Commission "to act in conjunction with the United States Secretary of Labor to obtain Federal aid for the purpose of erecting wage earners' dwelling houses." ${ }^{1}$

1 For this reference, as well as for her first acquaintance with the Oregon and South Dakota enactments described in Chapter XI and with the extremely important California activities under the Veterans' Welfare Board to be described later in this chapter, the writer is indebted to an unpublished digest of Constitutional and Statutory Provisions prepared under the direction of Dr. S. James Herman of the Michigan Housing Association in 1926. 
This may have been intended for credit rather than building. but st all events nothing came of it.

\section{The State of North Dakota}

The ill-starred effort of the Non-Partisan Lesgue to include state housing in its half-baked program of eclectic reform has given considerable comfort to the antis. who point to the incident ss showing thst housing by public suthorities cannot take root in American soil. It might of course. ss well be argued that the fonPartisan League s failure to improve the marketing facilities of the farmers proved that this also can not be done.

The growth of the Non-Partisan League from 1915 to 1920 in North Dakots and twelve other western states. with a membership of some $230.000 \mathrm{ws}$ due to a genersl feeling of discontent smong the farmers and a belief that they were being exploited by those who handled their products Arthur C. Townley sppesred like snother Moses offering to lesd them into the promised land. and they started of without much inquiry into his objectives or his qusliticstions for lesdership. They were graduslly disusted by his mismansgement and sutocrstic methods and by the excessive taxation in which they found themselves involved. The 1020 elections gresily reduced the Non-Partissn Lesgue majorities and a Recall election in 1921 completed the work of knocking down the house of cards:

The housing festure had been only s minor detsil. In 1919 the North Dakota legislature sdopted a messure (Chsp. 150) declsring it to be the purpose of the State to "engage in the enterprise of providing homes for residents of the Stste and to thst end to establish "See "Socisl Politios in the Tnited States," Frad. E. Haypes, Chspter
XIII, The Non-Partisen Lesgue. 
a business system operated by the State under the name of the Home Building Association of North Dakota." The proposed organization was to be managed by the Industrial Commission of North Dakota. Land was to be bought, houses built and sold on a basis of $20 \%$ down and monthly installments. No house was to cost more than $\$ 5000$. One hundred thousand dollars was appropriated to carry out the provisions of the act. In $1921, \$ 250,000$ was appropriated to wind up the affairs of the Home Building Association. What, if anything, happened in between, this inquirer has never been able to learn.

\section{The State of Wisconsin (Milwaukee)}

As a not-too-successful coöperative venture, the Garden Homes Company of Milwaukee was briefly described in Chapter X. It was there stated that its organization and financing presented features highly unusual in this country. It would seem logical to call it an experiment in financing by public authorities, rather than housing by public authorities, had not the Mayor of Milwaukee, Hon. Daniel W. Hoan, recently described it under the latter head. In the July, 1930, number of The American City, he calls it "the first semimunicipal housing project ever undertaken in this country," and his connection with it has been so intimate that we must defer to his diagnosis.

The first step had been the appointment by the Mayor of a Housing Commission of eleven members, with William M. Schuchardt as chairman, which presented an unusually thorough-going report on November 30,1918 . It dealt not only with emergency relief for the housing shortage, but studied "the best methods pursued in this country and abroad" and offered "a plan 
of action whereby all the elements of our social structure may be properly and economically housed in adequate environments". The plan included the elimination of speculative land value in residential districts, zoning, city planning, elimination of waste in building, acquiring for wage earners of benefits of ownership without interfering with labor mobility, legislation aiming to stimulate the erection of wage earners' homes, and public instruction as to the possibilities of housing betterment.

The legislation finally decided on and secured with the aid of Mayor Hoan and others, was an enabling act permitting cities and counties of the state to purchase preferred stock in coöperative housing companies in order to assist in their financing. This stock is eventually retired as the tenant-owner pays for common stock to replace it. He also pays interest on it in the meantime, so that there is no subsidy involved or expense for the taxpayer. The method is fairly often employed in Europe and is considered very conservative.

Under this act, the Garden Homes Company was organized, the preferred stock of $\$ 550,000$ being subscribed for by the City and County of Milwaukee and by a group of business men representing the Chamber of Commerce. ${ }^{3}$

At the Third Congress of the Coöperative League of

${ }^{3}$ From a type-written report sent by Frank J. Harder, one of the directors, to Prof. Benj. R. Andrews, of Teachers College, Columbia University, in Feb. 1927, the following particulars are taken.

"The company purchased a 30 acre tract of land adjoining the City at a price of 1000 per acre, upon which were erected 105 homes. The entire plot contained when plotted, 164 building lots, and an entire square which was given to the City for park purposes and another tract which was sold to the School Board for the erection of a school house. Although we have paid a little less than $\$ 30,000$ for the entire tract, we have realized over $\$ 55,000$ from the sale of the vacant property, which were the lots remaining after the erection of the 105 homes. This not only gave us without cost the 105 lots upon which the homes 
America in 1922, Mayor Hoan said that there had been 600 applications for the 90 houses then completed and that it was hoped 1923 would see 1000 homes ready for occupancy. An ultimate program of several thousand was anticipated.

In view of the fact that nothing further has been done in all these years after completing the first project of 105 houses, it is hard to share Mayor Hoan's conviction as to its success, however much we would like to. The coöperative spirit was lacking in the tenant owners. The Chamber of Commerce, one learns from various sources, was luke-warm or worse as to further financing. But the demonstration had been made that it could be done, the enabling legislation is still in existence, the need for housing undoubtedly still exists, municipal administration is still in the same hands. May we not hope that the necessary changes in method will be made and that Mayor Hoan will show us in Milwaukee an example, rather than a sample, of successful municipal housing?

\section{State of New York (Cohoes)}

This is an instance of undoubted municipal housing, which, however, proves very little. Like so many

were erected, but also left a sum of over $\$ 20,000$ remaining for operative expenses during the construction period."

For a house costing $\$ 4800$ (a trifle above the average) the down payment was $\$ 500$, according to a table furnished by Mr. Harder, with a monthly payment of $\$ 49$ for 25 years, when the purchase will be complete. Of this, $\$ 24$ a year goes for administration, $\$ 48$ to a contingent fund to repurchase stock at cost from those who leave, \$9 fire insurance, $\$ 172$ is credited the first year to taxes, repairs and depreciation, which increases to $\$ 294$ in the 25th year. Interest payments are $\$ 215$ the first year and decrease to $\$ 33.11$ in the 25 th year, while the amount credited to purchase of stock increases from $\$ 120$ in the first year to $\$ 179.89$ in the 25 th.

Mr. Harder feels that quantity production decreased the cost of the houses by $\$ 1000$ to $\$ 1500$ each. The development is now within the city limits. 
others, this industrial town in the Albany district suffered from the post-war housing shortage and found the private builders and private capital too timid to enter the field. The City Council thereupon made an appropriation in the neighborhood of $\$ 100,000$ and the city itself built and sold as many small frame houses, costing about $\$ 4500$ each, as its funds would produce. No enabling legislation was sought, and there has been no court test of the legality of the Council's action. The question as to whether municipal housing would require an amendment of the state constitution is no nearer settlement than before.

\section{State of New Jersey (Newark)}

Chapter 12 of the Laws of 1917 authorizes "any city, for the purpose of housing and caring for the poor of such city, to acquire lands, within or without such city, by purchase or condemnation, to improve such lands, to erect, reconstruct, enlarge and furnish buildings and to sell lands and buildings used for said purpose." This is another case of still-born legislation.

Of a very different sort is Chapter 201 of the Laws of 1929 enacted to permit the Prudential Insurance Company to undertake slum clearance and rehousing operations in Newark with the coöperation of the municipality. The act as passed contains a preamble setting forth that "congested, unsanitary and dangerous housing conditions" exist in cities of the first class, which it is the purpose of this legislation to eradicate. It empowers insurance companies to present plans for the approval of the governing body of the city looking to the purchase and demolition of insanitary and unsafe buildings and the "construction of new housing facilities 
under public supervision." Supervision extends to rentals, which must be "within the means of wage earners of the lowest earning capacity." If this provision is carried out, another provision forbidding the insurance company to make more than a $6 \%$ profit on its investment will be quite superfluous. Where the insurance company is unable to acquire an approved tract at a fair price, the city may exert the power of eminent domain on its behalf.

Such a relationship is a long way from full-fledged municipal housing, but it does constitute a sort of partnership. As originally planned by Mayor Jerome T. Congleton, there would have been a situation not unlike that which existed in London between 1870 and 1890, when the Metropolitan Board of Works condemned, acquired and cleared slum areas and sold the re-planned sites to housing foundations or to limited dividend companies for the erection of model tenements.

So far, the city's powers of condemnation have not been invoked. Without its help, the Prudential Company has acquired three sites. The first occupies the block bounded by Passaic and Fleming Avenues and Lexington and Oxford Streets. Garden apartments are being erected on this site, of the general type which has now become familiar, covering only $39 \%$ of their site. They are planned to rent at from $\$ 11.50$ to $\$ 14$ per room per month and will house 406 families. This group is in what is known as the Ironbound District of Newark and will be called the Chellis Austin Apartments. It is not expected that their net return on the investment will be more than $4 \%$.

A two-block site in the Negro section of the Third Ward is bounded by Somerset, Barclay, Montgomery and Spruce Streets. Plans call for two-room-deep 
apartments on the long sides of the blocks and for the acquisition and development of the centers and ends by the city as parks and playgrounds. The city's action was held up, temporarily, by a tax-payers' suit.

A third site comprising 19 acres is being reserved for future development to serve the projected Westinghouse plant and other industries on recently reclaimed Newark meadows.

Altogether, while the city's participation in the Newark housing projects is encountering considerable opposition, it also has strong backing, and the end is still uncertain. As to Newark's great need of better housing, there can hardly be two opinions.

It is of interest to note that Lawrence Veiller has been acting as consultant to the Prudential Company in connection with its housing plans. It should, perhaps, be added that he is not responsible for the writer's classification of the Newark project as semi-municipal housing.

State of California (Land Settlement Act and Veterans' Farm and Home Purchase Act)

California is a state geographically and temperamentally removed from the conservatism of the East, given to seeing things in the large, to wrestling with new problems, and not afraid to experiment.

The Land Settlement Act was passed by the Legislature in 1917 and amended in 1919. Its object is stated to be "to provide employment and rural homes for soldiers, sailors, marines and others . . . , to assist deserving and qualified persons to acquire small improved farms, to demonstrate the value of adequate capital and organized direction in subdividing and preparing 
agricultural land for settlement, and to provide homes for farm laborers." The veteran feature has never been emphasized.

A Land Settlement Board of five was appointed with Dr. Elwood Mead of the University of California, an irrigation engineer with Australian experience, as chairman. Dr. Mead gave much thought and constructive enthusiasm to the project. Two settlements resulted, neither of which in final outcome, has proved wholly successful, though one came much nearer to it than the other.

Durham Land Settlement is in Butte County, about ninety miles north of Sacramento. The Board purchased the tract, subdivided it in farm allotments of 20 to 160 acres and in farm laborers' allotments of 2 acres and sold it to settlers during the summer and fall of 1918 , leasing part of the tract to be sold later. The 1917 appropriation had been for $\$ 260,000$. A million was added in 1919, when a second settlement was provided for. The Board completed an irrigation project costing $\$ 140,000$. There are 22 miles of open ditches and 12,580 feet of concrete pipe, the latter chiefly supplying the laborers' allotments.

Terms of sale were $5 \%$ down and the balance in semiannual installments for 20 years, with interest at $5 \%$. Loans were also made for improvements, livestock, implements, etc., not to exceed $\$ 3000$ to any individual or $60 \%$ of the appraised value of the security. The settler was not to be an owner of agricultural land worth more than $\$ 15,000$, including this purchase. He must be ready to take up bona fide residence on his land within six months.

The rural community center contains school, church, stores and community hall. Twenty-two acres covered with oak trees were reserved for a park and play- 
ground. A bus carried the children to and from school. The Board employed a superintendent to act as the friendly practical adviser of settlers. A "farmstead engineer" helped plan farm buildings and to lay out the farms. He specialized in plans for unit houses, so that a settler might start with a two-room cottage costing $\$ 500$ and his own labor and gradually acquire a fully equipped $\$ 5000$ home.

The Durham tract contains 6200 acres. About 5000 acres were sold to 90 farmers and 26 farm laborers, 360 acres were leased for three years and subsequently sold. About 700 acres were too high to be irrigated by gravity and were reserved for pasture. About $\$ 30,000$ was spent in preparing farms for cultivation before they were turned over to settlers, apart from the irrigation project already mentioned. The irrigated land is suitable for grain, fruit, alfalfa and vegetables. On June 30, 1920, the total indebtedness of the settlers at Durham to the State was about $\$ 900,000$, of which less than $\$ 10,000$, or about $1 \%$, was in arrears. The surplus of assets over liabilities was $\$ 185,000$. The initial capital of the farmers at Durham varied from $\$ 1500$ to $\$ 15,000$, the average being $\$ 6700$. The capital of farm laborers varied from $\$ 20$ to $\$ 4,700$. At the close of 1924 there were 140 families in the Durham settlement. The then chairman of the Board, C. M. Wooster, in a December 1924 letter to the writer, expressed the belief that the Durham Settlement would pay for itself without loss to the State, while the less fortunate settlement at Delhi would probably involve considerable loss.

The Delhi tract, comprising 8,700 acres, is in the San Joaquin Valley, 98 miles south of Sacramento. It is desert land, depending wholly on irrigation. The land was seeded in alfalfa and 130,000 rooted grape vines were planted before the farms were sold. In December, 
1924, 220 families had settled there. Extensions had been made of unpaid interest installments. In the letter already referred to, Mr. Wooster said: "Those who have the determination, fitness and grit will, doubtless, pull through successfully, but will not have realized their expectations. The loans to settlers were stopped because the funds became exhausted. Funds were too liberally advanced, and some were impoverished by over-credit, and some who were misguided expected the impossible." The passage of time did not improve the situation. In 1925 nearly $\$ 300,000$ owed the State by Delhi settlers was wiped out in a revaluation of their land. A Legislative Committee of the same year recommended that the State of California should never enter into another land settlement scheme. In 1927, the Legislature transferred the administration of the settlements to a Division of Land Settlement created for the purpose in the Department of Agriculture, and one feels that arrangements are being made for the patient's funeral. The new Division's first report, Dec. 1927, contains the statement: "The responsibility amounted to a virtual receivership, involving 14,600 acres of land, 390 settlers, and an investment of some $\$ 3,000,000$ on the part of the State." The figures bear out the statement so far as Delhi is concerned. In regard to Durham, the matter is at least debatable.

Under legislation of 1928 and 1929, measures have been taken to effect the complete withdrawal of the State from the colonization enterprise. It remains a mortgage holder and an owner of unsold land, but the colonists are taking on all administrative responsibilities. In a letter dated April 29, 1931, Charles W. Cleary, Chief of Division of Land Settlement, says that "the State has been willing to sustain a loss of nearly two and a half million dollars in order to effect immediate 
withdrawal," that the withdrawal is already complete as to Delhi and will soon be as to Durham, and that then "every vestige of paternalism will be eliminated."

While these experiments in rural community building were in progress, the State Commission of Immigration and Housing had been seeking aid for the urban population. In 1921 it drafted a bill providing state aid to home builders. The Legislature postponed the issue by passing the Flaherty bill directing the Commission to "investigate the practicability of the State of California assisting the workingmen to acquire and build homes, and to report to the next session of the Legislature a bill or bills carrying it out, whereby, with the assistance of the State, workingmen may acquire lots of ground and build houses thereon, such lots and houses to become homesteads and to be sold on the installment plan" (Ninth Annual Report, Commission of Immigration and Housing of California, Jan. 9, 1923, p. 85).

The Commission made a survey of congestion and housing conditions in San Francisco, Los Angeles, Oakland, Sacramento, San Jose, Fresno, Long Beach, Hayward, Venice and Watts, which together contain $45 \%$ of the population of the state. They also collected existing material on the relation between bad housing, infant mortality, tuberculosis, etc., and on methods of financial aid adopted in European countries and in the United States to relieve the housing shortage. Their resulting Report on Housing Shortage was issued early in 1923. Their survey, which had included homes of all grades of manual and clerical labor, pronounced $45.7 \%$ of them bad and $14 \%$ fair, both of these groups falling below the minimum standard set by the State Housing Law. Thirty per cent of the homes visited were overcrowded, $48.5 \%$ were without adequate bath- 


\section{Housing by Public Authorities}

ing facilities and $30 \%$ without adequate toilets. Owned homes averaged much better than rented ones.

As directed by the Legislature, the Commission offered with their report a bill "to assist persons of moderate means in acquiring lots of ground and building houses thereon, such lots and houses to become homesteads and to be sold on the installment plan and making an appropriation therefore" (Senate bill No. 53, Assembly bill 94, Legis. 1923). Any citizen of the United States whose assets did not exceed $\$ 1000$ and whose gross income did not exceed $\$ 1800$ might be an applicant for one lot or house, which he must be prepared to occupy within six months. The Commission of Immigration and Housing, after approving applicant and proposed home, was to acquire same at not-to-exceed $\$ 5000$, applicant to pay down at least $5 \%$ of purchase price, balance to be amortized in not-to-exceed 40 years, with interest at $5 \%$. Sale or transfer forbidden without consent of Commission until payments were complete. Insurance and other safeguards to be required. An appropriation of $\$ 2,000,000$ was asked for, $\$ 50,000$ of which was to be for administrative purposes, the rest to constitute a revolving fund for the purchase of homesteads. The bill failed to pass. For the time being, at least, the efforts of the State Commission in this direction came to an end.

Another California project, the outcome of which is still uncertain, should be noted at this point. Several years ago, through the efforts of William Mead, a public spirited citizen especially interested in housing, the Los Angeles city charter was amended to permit the appointment by the Mayor of a Housing Commission of fifteen members. The Commission is empowered (1) "To incur indebtedness by the issuance of bonds in the name of the City of Los Angeles, under such terms and condi- 
tions as shall be prescribed by the Council by ordinance, for any of the purposes for which the board is authorized to provide ... provided that such bonds shall be a lien upon the property of the Municipal Housing Commission alone and the city shall not be liable on account thereof." (2) "To provide by purchase, lease, condemnation, construction or otherwise, and to improve, rent, manage, sell and repurchase lands, dwellings, apartment houses, lodging houses or tenement houses, for the purpose of improving the health, safety and welfare of the inhabitants of said city, by providing homes for those who might otherwise live in overcrowded tenements, unhealthy slums, or the most congested areas, ... provided that whenever any such property shall have been transferred into private ownership, the same shall immediately become subject to taxation." The Commission is also authorized to receive gifts or bequests.

In order to test the constitutionality of the principal charter provisions, the City authorized a million dollar bond issue, which was made the subject of a friendly suit before the State Supreme Court. A favorable decision was eventually rendered. Meanwhile, however, Mr. Mead had died. His will provided $\$ 200,000$ to establish the Mead Housing Trust, the balance of the estate going to Mrs. Mead for her lifetime, with reversion to the Housing Trust at her death. Mrs. Mead is anxious to carry out her husband's wishes, and if a suitable plan of action can be worked out, she is prepared to give substantial assistance.

California is one of the States with a constitutional bar to housing loans. The revolving fund for purchase and sale of homesteads, which had been proposed by the Commission of Immigration and Housing, was intended to avoid this difficulty. As will be seen, a similar ex- 
pedient was adopted in the case of the legislation for veterans. In both cases, the net result is precisely equivalent to a system of state housing loans. It is because of these legal features that both measures are treated here under the head of housing by public authorities rather than housing loans by public authorities. The lack of success of the Commission's bill in the Legislature would appear to be due to a lack of the vigorous and well organized public support which secured the enactment of the American Legion's measure about to be considered.

We have now arrived at what the writer believes to be one of the two events of outstanding importance in the post-war American housing field,- the adoption and carrying out of a plan under which the State of California has already aided over $7,500^{4}$ of her veterans to attain home ownership, in a movement still in full swing, without a cent of expense to the tax-payers.

In its session of 1921, the Legislature enacted several bills sponsored by the American Legion. The one which chiefly concerns us here was the Veterans' Farm and Home Purchase Act (Chap. 519). The California Veterans' Welfare Act (Chap. 590) is also important for us in that it created the Veterans' Welfare Board, which administers the Home Purchase Act. It was also intended to establish one or more agricultural colonies for veterans, but inquiry among them showed that no substantial demand existed for such developments. For individual homes, and to a less extent for individual farms, the demand was-and still is-keen.

The Farm and Home Purchase Act authorized an issue of bonds to the amount of 10 million dollars to be used in the purchase of homes and farms to be resold to veterans on the installment plan (approved by vote of

47213 are purchasing homes and 290 are acquiring farms. 
the people, November 1922). This amount was exhausted in 1925, when an additional issue of 20 million dollars was authorized (Chap. 430, Statutes of 1925) and approved by referendum in 1926 . This issue was also exhausted in 1929, when a further 20 million dollar bond issue was provided for and approved by referendum in November 1930.

The Report of the Veterans' Welfare Board to June 1930 , records 35,520 applications received for home or farm, 15,455 of which had been approved (including 7,503 under contract) and 650 of which were pending. Of the remaining 19,415, 181 had been canceled by death, 550 at the applicant's request, and 4077 "for lack of coöperation." The remainder had been nermanently or temporarily disapproved as not coming under the provisions of the law-too much property, lack of dependents (home), lack of farm experience (farm) etc. Of those who have already received homes, 1789 are wounded or disabled and 5424 able-bodied. The farmers include 87 wounded or disabled and 203 able-bodied. According to the estimate of the Board, over $90 \%$ of these men and women could not have acquired homes or farms in any other way.

The applicant must have served in the active forces of the army, navy or marine corps during any war in which the United States has been engaged, including Indian Wars, Philippine Insurrection, and Boxer Rebellion, must have been a bona fide resident of California at the time of enlistment or commission, and must possess an honorable discharge. He must not be in possession of real estate, including what he is planning to acquire, exceeding $\$ 15,000$ in value. He must be seeking the home or farm for his own occupancy. The State will not expend more than $\$ 7,500$ for a farm or more than $\$ 5000$ for a home, but a home may cost up 

to $\$ 7500$ if the veteran finances the difference himself. The home may be one already built or one which is to be built. The veteran must pay $5 \%$ of the purchase price of a home financed by the State as a down payment, or $10 \%$ of the price of a farm, and $5 \%$ in either case to cover the cost of administration throughout the life of his contract. He amortizes the remainder of the purchase price and pays $5 \%$ interest on the balance in equal monthly installments extending over 20 years. Thus on a $\$ 5000$ home, he will make a $\$ 500$ payment ( $\$ 250$ down payment on principal and $\$ 250$ administration charge) and his monthly payment of principal and interest will be $\$ 33.10$. On a $\$ 7,500$ farm, his annual payment will be $\$ 560.50$

This, of course, does not include the taxes, fire insurance and repairs which are usually given in reckoning carrying charges. For California veterans acquiring a home under this act, the tax item is almost non-existent. In a majority of counties, such property is tax exempt as long as the title remains in the name of the State, or until payments have been completed. In all parts of the state, veterans are entitled to a $\$ 1000$ tax exemption and are only taxable on their equity, from which the $\$ 1000$ is deducted. The Board has arranged for blanket fire insurance which reduces the cost $40-60 \%$. The item of repairs, then, is the chief addition to be made to the very low charges recorded.

The advantages to the veteran are:

1. A lower price for his home because it is a cash purchase. The inflated sales price due to a discounted second mortgage and the expense of a first mortgage have been eliminated. The Board estimates this saving at from 10 to $15 \%$.

2. The small down-payment required.

3. Low interest rate. The difference between $5 \%$ and the $7-10 \%$ charged by private business concerns, including 
Building and Loan Associations, in California, is substantial.

4. Repayment spread over 20 years.

5. Partial or complete tax exemption under California law.

6. The very great advantage to the veteran of the trained business judgment of the Board in guiding his selection of a home in the matters of site, plan, building materials, workmanship and price, in which the inexperienced are so likely to make serious mistakes. The Board is concerned to see that the veteran gets his full money's worth, not only for his own sake, but in order to insure the safety of the State's investment.

The average cost of the homes so far purchased has been $\$ 4,742$. (Farms, $\$ 5,491$.) The photographs of sample homes which illustrate the reports show a high grade of modern comfort and in many cases of architectural charm.

It is of interest to know how these seven thousand and odd veterans (many of them disabled) and widows of veterans are making out. Enough years have passed to make a pretty fair test. One hundred and six have got enough ahead of the game to complete their payments instead of spreading them over twenty years. The number of homes repossessed and resold up to June 30,1930 , was 246 , and the result was a net gain to the State of $\$ 7,134.33$. Of the farms, 34 went through the same process, with a net gain to the State of $\$ 3,372.95$. That is certainly a remarkable record, bearing eloquent testimony to the careful administration of the Veterans' Welfare Board in the public interest. At the same date, 1532 accounts (21.27\% of the total number) were in arrears to an average amount of $\$ 81.90$, or a total of $\$ 125$,469.56. Sickness and assessments for improvements were the chief trouble in the earlier years. Unemployment became a factor toward the end. The proportion of delinquents was naturally much higher among the 
disabled. But it was expected that most of them would eventually pull through. The state bonds issued have paid interest at $4,41 / 4$, and $41 / 2 \%$. The difference between that and $5 \%$ interest paid by the veterans, less expenses of bond issue, has built up a reserve fund to protect the State from possible loss. Administration costs, the veteran himself has paid for. The Board has been able to retire $\$ 2,000,000$ of the bonds.

Past National Commander John R. Quin of the American Legion, who has also served as Chairman of the California Veterans' Welfare Board, has called the Farm and Home Purchase Act "the most far-sighted piece of veteran legislation enacted by any state." "By this legislation," he says, "the State of California acknowledges the war service of the veteran by helping the veteran to help himself. It is self-sustained, free from any element of charity, and accomplishes the two-fold objective of adequately expressing appreciation for war service while building substantial, law-abiding, homeowning citizenship."

The claim is fully justified. It is so much the most far-sighted piece of veteran legislation since the War that there is no comparison. Imagination fails in trying to conjure up the picture of what might have been the result if the other states had been equally wise, or if the National Government had enacted a similar measure on a nation-wide scale instead of the unsound, ineffective bonus act for which the tax-payers must expend billions, and by which the veterans benefit so little.

Inevitably, the next thought comes. If it is good for the veterans, why not for the rest of the population? Since there is no bonus-no subsidy-no expense to the tax-payers, why not go back to the idea of the Commission of Immigration and Housing and have a homepurchase act for all small-income families? 
It can never again be truthfully said that no American state has lent its aid to home-ownership, or that it has never been done successfully, or that it has never been done on a large enough scale to have significance. Credits of 50 million dollars are not an insignificant figure. Seven thousand five hundred homes and farms are not an insignificant accomplishment, nor do the even greater number of approved applicants waiting their turn suggest any slackening of interest. 


\section{CHAPTER XIV}

\section{THE NEW YORK STATE BOARD OF HOUSING}

THE two outstanding developments in American housing of the past decade are found at opposite extremities of the continent. One is the aid to home ownership given by the State of California, described in the last chapter, the other the aid to housing by limited dividend companies given by the State of New York. The California aid is confined to veterans, the New York aid has no limitation as to class of beneficiary. California excludes veterans who have means enough to take care of their own housing. New York excludes housing organizations which do not limit their profits to $6 \%$. California got started five years earlier and has a much larger accomplishment record by number of families provided with homes. If present New York results were compared with California results of five years ago, however, they would not be very different in a numerical sense. One of the most striking differences is that the California law has been taken advantage of in 54 out of the 58 counties in the state, whereas no use whatever has been made of the New York law outside of New York City. Obviously, California is fostering home ownership, which is even better adapted to small towns and rural districts than to the big cities, while the rental basis or coöperative ownership possible under the New York law makes it normally urban. It could conceivably be used for building individual homes, 
but is not likely to be. Both in California and New York, it was the impossibility of having state housing loans without changing the state constitution which produced the particular kind of assistance given. The supervisory powers of the state administrative board are of great service to the inexperienced beneficiary in both cases. Tax exemption figures in both as a means of reducing costs. California places a maximum value on homes and farms she will finance, in order to confine the benefits of the law to those who really need them. New York fixes maximum rentals in order that the law's benefits may be conserved for tenants and cooperators who need help.

\section{The New York State Housing Law of 1926}

The recommendations of the Housing Committee of the Reconstruction Commission for an amendment to the state constitution permitting state housing loans, Governor Smith's endorsement, and the Legislature's lack of interest, all of 1920, have already been described. In Chapter XI, will be found an account of the efforts of Governor Smith and the Commission of Housing and Regional Planning on behalf of the proposed constitutional amendment in 1924 and 1925 and the effort in 1926 to secure a State Housing Bank which would afford the desired credit without amending the constitution. We are now concerned with what remained of the housing bank bill after the housing bank had been cut out of it.

At first sight, the shell without the egg hardly seemed worth preserving, but Governor Smith wisely decided to sign the mutilated measure presented to him, and in practice it has produced surprisingly good results.

1. The preamble and legislative finding at the be- 


\section{The New York State Board of Housing 261}

ginning of the Act form a valuable statement of intolerable existing housing conditions and of the responsibility of the State to find a remedy. ${ }^{1}$

2. The act created the State Board of Housing as an unpaid board of five, appointed by the Governor, with a paid technical staff, having the fact-finding and policyadvising functions of the Commission of Housing and Regional Planning, which it superseded, as well as the duty of administration of the new law.

3. Two types of limited dividend housing company were recognized, distinguished as "public" and "private." The chief difference was that the public limited dividend company may exercise the power of condemnation, but may not sell or otherwise dispose of land so acquired except to another public limited dividend housing company, the transfer being approved by the State Board of Housing. The private limited dividend company has no power of eminent domain, but has greater freedom in disposing of its property, always, however, subject to the approval of the State Board. In practice, the private form has been used, so far, exclusively.

4. In order to receive the approval of the State Board

${ }^{1}$ Chapter 823, Laws of 1926, describes itself as "An Act to promote the public health and safety by providing for the elimination of unsanitary and dangerous housing conditions, to relieve congested areas, and the construction and supervision of dwellings and for the letting of apartments at reasonable rentals." The legislative finding begins: "It is hereby declared that congested and unsanitary housing conditions which exist in certain areas of the state in low priced dwellings are a menace to the health, safety, morals, welfare and reasonable comfort of the citizens of the state. The correction of these conditions in such areas being now otherwise impossible, it is essential that provision be made for the investment of private funds at low interest rates, the acquisition at fair prices of adequate parcels of land, the gradual demolition of existing unsanitary and unsafe housing and the construction of new housing facilities under public supervision in accord with proper standards of sanitation and safety at a cost which will permit monthly rentals which wage earners can afford to pay and not in excess of the rates hereinafter provided." 
of Housing and the consequent benefits, limited dividend companies, whether public or private, must provide one third of the capital necessary for their project and must limit themselves to a $6 \%$ return on it. They must raise the balance by first mortgage on which they may not pay over $5 \%$ interest. They are permitted to accumulate a surplus not exceeding $12 \%$ of the outstanding capital stock. Any excess of receipts above authorized interest and surplus shall be applied to the reduction of rents. In case of dissolution, non-distributed earnings in excess of $6 \%$ shall go to the State of New York.

5. In addition to the above characteristics of the limited dividend company, those operating under the State Housing Law must also accept limited rent. This is on a per-room-per-month basis, including heat, and varies in location in relation to average cost of land. As passed in 1926, the maximum rental was $\$ 12.50$ in the borough of Manhattan, $\$ 11$ in Brooklyn and the Bronx, $\$ 10$ in Queens and Richmond and in first class cities generally, and $\$ 9$ elsewhere. At the request of the Housing Board, the law was later amended to change these absolute maxima into average maxima, as it was found necessary, especially in walk-ups, to vary rentals within a building according to the relative desirability of the apartments. Later still, also on the Board's recommendation, the $\$ 9$ and $\$ 10$ categories were cut out, leaving $\$ 11$ as the maximum average rent anywhere outside of Manhattan. ${ }^{2}$

6. Approved limited dividend companies complying with these terms are exempt from State taxes or fees. Municipalities may exempt the buildings and improvements of these projects from local taxation. And, as

2 The act was amended, at the request of the Board, in 1927, 1928 and 1930, to make it work more smoothly, but the other changes need not detain us. 
The New York State Board of Housing 263

already mentioned, public limited dividend companies may, with the approval of the Housing Board, exercise the right of condemnation, in order to round out a site of suitable size and shape. So far, the right has not been used.

7. In the writer's judgment, one of the most useful features of the law is the control established over the business procedure of the approved companies by the State Board of Housing, one of whose members is obliged to serve on the board of directors of each company. In the case of coöperative companies made up of persons of small means without much building or business experience, this supervision is invaluable. It literally saves them from themselves.

\section{New York City Grants Tax Exemption}

The Legislature having cut out the housing bank which was to lend money to limited dividend companies at a low interest rate, the only way offered by the law to reduce rentals, aside from the elimination of speculative profit by limiting the dividend and the minor saving by exemption from state taxes, was the exemption from local taxation, which the Legislature could only permit-not order. The matter has never received serious consideration except in New York City. Due to an unfortunate lack of team-work between the Governor and the Mayor, it came very near not receiving it there. It took persistent hammering by a number of civic organizations and more than a year of delay to secure the passage of an ordinance granting twenty years' tax exemption to buildings erected prior to January 1, 1937, by public or private limited dividend housing companies under the state law. ${ }^{3}$

${ }^{3}$ Local Law No. 9 of the City of New York, approved by the Mayor on June 22, 1927. A copy is printed in the appendix of the Report of the State Board of Housing of February 29, 1928. 
vested capital would otherwise have brought them. Rent tables in the Board's 1930 Report (pp. 22, 23) show that more than four fifths of the apartments in the two Amalgamated Housing Corporation projects have from three to four and a half rooms (the half room being a dining alcove), and that rentals, which average $\$ 11$, actually run from $\$ 9$ to $\$ 12.50$. Monthly rentals of apartments run from below $\$ 25$ to over $\$ 72.50$, the great bulk of them being between $\$ 30$ and $\$ 55$.

Some families down to the $\$ 1500$ limit would be able to live in the cheaper apartments, but they would also be the families least likely to have saved up enough capital to buy their stock without help. It would only be those without children, one would think, who could manage the repayment of a note in addition to rent. Mr. August Heckscher, having picked up in a casual way the idea that garment workers make from $\$ 10$ to $\$ 19$ a day (which may be true of a few cutters and highly skilled piece-workers, but is far from true of the generality), jumped to the conclusion that the Amalgamated houses were peopled by families at this income level and gave considerable disparaging publicity to the project and to the State Housing law on that basis. Mr. Sidney Hillman, president of the Amalgamated Clothing Workers of America, wrote Mr. Heckscher a letter of protest in the early days of 1928, in which he called attention to the fact that the (average?) wages of clothing workers in New York City at that time were offcially reported (presumably by the State Commissioner of Labor), as $\$ 39$ per week, and that the seasonal character of the work resulted in an average employment of 40 weeks per year, making average weekly wages throughout the year only $\$ 30 .^{7}$ But Mr. Hillman did

${ }^{7}$ The correspondence was published in a Heckscher pamphlet, "A Review of the Housing Situation," early in 1928. 
The New York State Board of Housing 267

not say to what extent garment workers making only average wages were able to live in the coöperatives.

Fortunately, this question is answered for us in a standard of living study of 400 Amalgamated Housing Corporation families, which forms part of the March 10, 1931, Report of the State Board of Housing. Only twenty-four per cent of heads of families earned less than $\$ 40$ per week when fully employed, indicating, as was to be expected, that the group is economically above the clothing trade average. On the other hand, $80 \%$ of the families fall below the minimum assumed by Mr. Heckscher to be typical. Less than a third of the Amalgamated tenants, by the way, belong to the clothing trades at all. In confirmation of the writer's conclusion, expressed in the Introduction, before this material was available, is the showing that sources apart from the chief earner account, on an average, for only $12.4 \%$ of the family income. Table XXXI, giving family income, is so important that it is appended in full.

Number and Per Cent Distribution of Families Classified by Size of Family Income

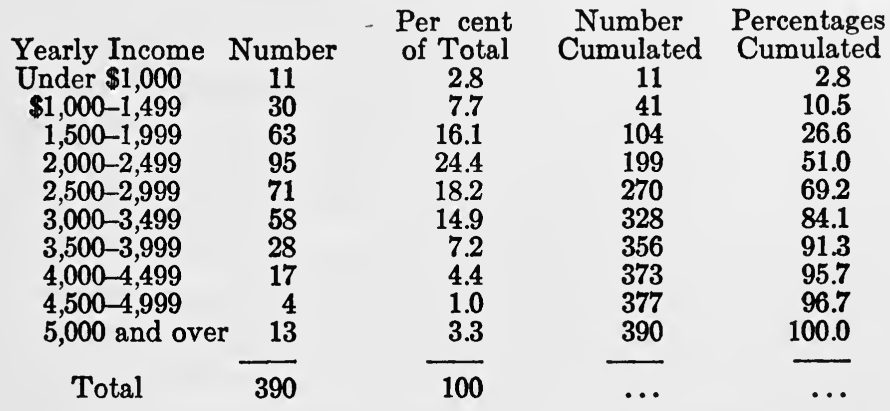

It will be observed that 104 families have incomes under $\$ 2000$ and that 41 of them are under $\$ 1500$. The largest group (95 families, $24.4 \%$ of the total) lie between $\$ 2000$ and $\$ 2500$. 
tenant Governor Lehman, purchased the site, when opportunity offered, and transferred it at cost to a limited dividend coöperative housing company as soon as one could be organized. Messrs. Lehman and Rabinowitz are also aiding in the financing of that third of the capital which has to be privately raised. The Bowery Savings Bank gave a mortgage at $5 \%$ for approximately two thirds of the total cost, estimated at $\$ 1,500,000$. As already stated, the undertaking is sponsored by the Amalgamated Clothing Workers and has Mr. Hillman for its president and Mr. Kazan for its vice-president and manager. There are 234 apartments with a total of $9191 / 2$ rooms, and there are 14 stores. Average rental is $\$ 12.50$ per month per room, with some as low as $\$ 10$. The project was completed in November 1930 . Tenant owners, here, as in the Bronx Amalgamated development, will have to subscribe to $\$ 500$ worth of stock per room, though a smaller cash payment is accepted.

The last three projects, sponsored by two firms of builders, have an interest all their own, because they are neither coöperative nor altruistically civic, but purely commercial. In times of prosperity, the State Housing Law would have had little attraction for them. Speculative builders do not normally agree to limit their profits to $6 \%$ on their investment. But in these days of business depression, 20 years of tax exemption, and a fairly safe $6 \%$, with a near-certainty that there would be no vacancies in their limited-rent apartments, looked better than inaction to a number of them. When it came to the point, a good many could not overcome the second-nature habits of years sufficiently to accept the low coverage and high standards set by the Housing Board. Others, who were willing enough to comply, could not assemble large enough plots of land for the garden apartment layout. But Lippman and Charles 


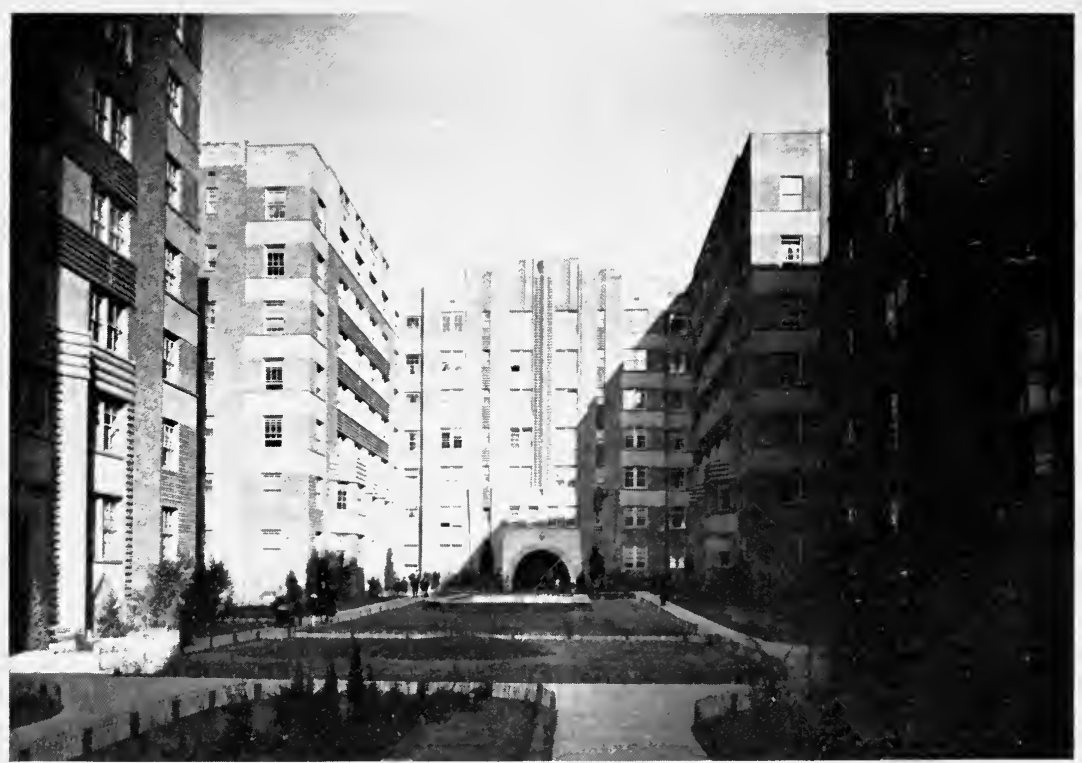

Courtesy of the New York State Board of Housing Amalgamated Dwellings, Grand Street, New York. 

The New York State Board of Housing 271

Schnurmacher and associates (Stanton Homes Corporation), were given the approval of the Board for a small apartment house at 193-197 Stanton Street, with a 100-foot frontage, which was completed late in 1930, and on February 21, 1931, the chairman of the Board, Mr. James, announced the Board's approval of their second project (Manhattan Housing Corporation), which will run from 176 to 182 East Third Street (105 foot frontage). Both projects are six-story elevator apartments, with incinerators and electric refrigerators, and the rents are limited to an average of $\$ 12.50$ per room. No stock purchase is involved. The number of apartments is 44 in each project.

The other commercial undertaking (Academy Housing Corporation), announced by Mr. James at the same time, is a much larger one. It will occupy the former site of the Clason Point Military Academy in the Bronx, overlooking the East River and Long Island Sound and will provide for 474 families, covering $43 \%$ of the ground. Total cost is estimated at $\$ 2,158,000$, of which the Metropolitan Life Insurance Company will provide $\$ 1,320,000$ covered by the usual 20 -year mortgage. The business men behind this development are Jacob Leitner and David Rose.

\section{Prognostications for the Future}

The getting under way of operations under the State Housing Law was slowed up by two difficulties-(1) lack of cordial coöperation by the city administration, as exemplified by the long delay in granting tax exemption, and (2) the competition of August Hecksher's rashly announced and widely advertised $\$ 8$-a-room-amonth-fire-proof-elevator-apartments, which have since evaporated into thin air without even an apology for 
the havoc wrought by their apparition. Obviously, proposals to raise money to build apartments to rent at $\$ 12.50$ per month per room fell on deaf ears so long as there seemed to be a prospect from another source of houses as good or better which would rent for $\$ 8$ per room.

These handicaps, however, have been overcome and the movement is gathering momentum. Just as it stands, it has a very useful part to play. It can occupy itself just so far and so long as capital is forthcoming in providing high-grade homes for families in the middle income group and for a few families in the lowest economic third. Those who wish to see rentals lowered sufficiently to cater to a large number of families in the lowest third can bring it about by putting through that long-talked-of amendment to the state constitution and a system of bond issues for housing loans controlled by the State Board of Housing. Loans should be permitted to coöperative societies or to public limited dividend companies for $95 \%$ of the necessary capital, as is done for the California veterans, or for $100 \%$, as is done in Holland for coöperatives and for publicwelfare housing societies. If that were done, we could have coöperatives without investments in stock, and the lower interest rate would reduce rentals. The public limited dividend companies would be multiplied many fold, as it is the difficulty of raising one third of the capital which limits their growth.

There is no need to offer public loans to commercial builders. They would wish to invest their own capital in order to get even a $6 \%$ return. Would it not be possible, however, on the basis of the recent experience, to include in plans for stabilization of industry and employment, a method by which, in times of financial depression, or when there had been over-building in the cus- 
The New York State Board of Housing 273 tomary residential field, builders should be encouraged to carry on large-scale limited-dividend operations under the State Housing Law, which would appeal to the unsatisfied wants of the lower income groups? This would keep organizations intact, prevent unemployment and improve housing. It is possible to imagine a sort of rhythm by which building during prosperity periods would be for the comparatively well-to-do and during depression periods for those of modest incomes. Prosperity building would be for the top economic third, and depression building for the middle third. 


\section{CHAPTER XV}

\section{SLUM CLEARANCE}

IF this work confined itself to goals attained or to concrete accomplishments, there would be no chapter on slum clearance, for so far, no such thing exists in the United States. But since it deals with trends, the subject can hardly be omitted. No one sensitive to the direction of popular feeling and popular aims can fail to realize that, in New York at least, we are rapidly approaching a slum-clearance frame of mind.

In Chapter VII on City and Regional Planning, will be found a brief discussion of a very few small-scale American efforts to get rid of slums, as such, by way of a city plan or a piece-meal establishment of playgrounds.

Washington has been making sporadic attempts to do something about its alley slums for the past fifty years. Quite recently the National Capital Park and Planning Commission evolved a plan, which was referred to in Chapter XIII, to use the organization of the United States Housing Corporation in the task of eliminating alley dwellings over a period of ten years. The plan involves the creation of a revolving fund composed of $\$ 500,000$ which the Housing Corporation already has to its credit and an equal amount to be appropriated by Congress. Congress is still to be heard from.

New Yorkers in recent years have at least become familiar with the term, slum clearance. They have accepted oft-repeated statements that nearly a third of the population live in old-law tenements, most of which ought to be torn down. 
The Heckscher agitation was fundamentally for slum clearance and rehousing by the municipality. Greatly stirred by the bad housing of which, apparently, he had suddenly become aware, Mr. Heckscher spent the summer of 1926 in Europe studying European methods. He came back firmly convinced that New York needed municipal housing and municipal slum clearance. His announcements to that effect did not awake much response. He next offered to be one of a hundred men of means to give half a million dollars each to a fund for clearance and rebuilding by private enterprise, if that must be the American way. But the other ninetynine failed to appear. Some one suggested utilizing the machinery of excess condemnation to arrive at municipal slum clearance without special legislation. Immediately, excess condemnation became the keystone of the Heckscher program, and a flood of publicity in favor of its use was launched by people, most of whom obviously did not understand either its purpose, its nature or its limitations.

Excess condemnation, secured in New York State through a constitutional amendment in 1913, permits a public authority acquiring property for street widening, the creation of a park or other public purpose, to buy more than is needed for the immediate project in order to control the surroundings (as of a park or public building) or to prevent having to pay high damages on uneconomic remainders of lots. The excess land, so acquired, must be sold or leased to the highest bidder. It has obvious uses in connection with slum clearance and might conveniently afford a method of initial experiment in municipal slum clearance-a sort of tryout before asking the legislature for proper direct authorization. Amusingly enough, its use for such a purpose had been suggested several years before by Lawson 
Purdy, who was the most scathing critic of the Heckscher proposals. But to suggest either that slum clearance had been one of the purposes for which excess condemnation had been secured, or that a great city program of slum clearance, involving the expenditure of hundreds of millions of dollars, could be carried on as an incident of widening streets, many of which did not really need widening, was absurd.

At all events, Mayor Walker endorsed the Heckscher plan in the early summer of 1927, and it thereupon became the Heckscher-Walker plan. It was necessary to amend the city charter to permit long leases of the leftovers obtained by excess condemnation. This was done by the Municipal Assembly and approved by the Mayor on September 2 and ratified by a popular vote, after a whirlwind publicity campaign, on November 8 .

The Heckscher-Walker plan, which formed the substance of the publicity campaign, promised streetwidening activity on a large scale, which should result in the city's incidentally acquiring and tearing down a great many old houses. The sites were then to be leased, for a long period, to individuals or companies on the basis of a $4 \%$ return to the city. The lessees were to build 10-story fire-proof elevator tenements to be rented at $\$ 8$ per room. Beyond that, everything was pretty hazy. Mr. Heckscher believed that the builder could do this and get $10 \%$ on his equity. As time went on, the references began to read " $\$ 8$ or $\$ 10$ " and some statements might be interpreted as meaning that rentals quoted did not include heat, for which an extra charge would be made. The consensus of responsible builders and architects was increasingly to the effect that the Heckscher estimates were based on insufficient study and could not, in fact, be carried out.

The first understanding was that the initial experi- 
ment would be made on ten blocks in connection with widening the lower part of Allen Street. Later, the scene was shifted to the seven blocks between Forsyth and Chrystie, East Houston and Canal Streets. After long delay, this site was acquired by the city and eventually the houses were torn down. Meanwhile, however, Mr. Heckscher had been discouraged by the delays (or had become convinced that his figures were wrong) and withdrew from the housing field, giving instead $\$ 4,000,000$ to his Foundation for Children, to be used in establishing a summer camp for children, as well as health centers and playgrounds in congested districts. ${ }^{1}$ Since which time, Mayor Walker has been described as carrying on a series of negotiations to get some one to build on that site. Recently, the Sub-Committee on Housing of the City Affairs Committee has been trying to persuade the Mayor to have the city do the building.

Mr. Heckscher, with the aid of the late Sophie Irene Loeb, has given slum clearance its widest publicity in New York and also its worst let-down. Those who know Mr. Heckscher and his record of benefactions cannot doubt his kindly intentions or his complete sincerity. They may well, however, doubt the wisdom of his course and regret the blanketing effect which his showy proposals had on the early efforts of the State Housing Board. They may also feel that he incurred, through his repeated promises, an obligation to the people of New York in connection with housing which could not be met by making them a gift of something else. Four million dollars as a housing foundation, operating under

${ }^{1}$ At the beginning of 1927, Mr. Heckscher had formed a National Housing Committee for Congested Areas with Mr. Hoover, then Secretary of Commerce, as Honorary Chairman, and an imposing list of university presidents and other laymen as members. Professor Charles Gray Shaw of New York University was executive secretary. The Committee, as such, never functioned, nor did the activities of Mr. Heckscher and Dr. Shaw ever get beyond New York. 
the State Housing Law, with 5\% mortgage money and no return on the equity (an average of $31 / 3 \%$ on the whole $\$ 12,000,000$ ), and 20 years tax exemption, would have meant good homes for about 2500 families on slum sites with rentals about $\$ 1.50^{2}$ per room per month less than the maximum allowed under the State Housing Law. And he could have controlled the system of choosing tenants so as to exclude all who could afford to pay more.

In the 1929 election for the Mayoralty, housing was featured as a fairly important issue. The Socialist candidate, Mr. Thomas, was out uncompromisingly for municipal housing. The Republican candidate, Mr. La Guardia, proposed to put the full strength of the city administration behind the State Board of Housing for greatly increased activities. Mayor Walker said less than either of the others. But he reaffirmed his faith in the excess-condemnation slum-clearance idea (although Mr. Heckscher had already retired) and promised prompt action at Chrystie-Forsyth Street.

Slum clearance has been advocated in many sources wholly unconnected with the Heckscher-Walker campaign. Lawrence Veiller has several times emerged from his Rip Van Winkle retirement to advocate slum clearance for New York, provided it is not attempted by back-door or haphazard methods. He points out that direct enabling legislation should be secured and a special authority created to carry it out. As chairman of the Division on Housing of the vast City Committee on Plan and Survey which Mayor Walker appointed at the beginning of his first administration, he wrote in its final report (1928) that nothing is more needed or more desirable in New York than slum clearance if the

${ }^{2}$ See table page 32, Report Commission of Housing and Regional Planning, March 6, 1925. 
city can afford it. He pointed out that in view of the enormous expenditures involved, "some method must be found by which a portion of the areas cleared of old buildings can be made so remunerative to the City as to pay a substantial part of the cost of the scheme." $\mathrm{He}$ also wisely said "Whatever is done should be closely related to a Comprehensive City Plan."

There was never a more perfect opportunity to relate slum clearance to a comprehensive city-and regional -plan than was open to the Committee on the Regional Plan of New York and its Environs, which, however, successfully side-stepped the whole issue. The Regional Plan Association is now calling for a general housing survey preliminary to such a step. But that does not answer the question why it was not done by the Sage organization while the staff and the funds were in being.

A body very much interested in some phases of slum clearance is the East Side Chamber of Commerce, which has made several useful little surveys of its own, as in regard to rear tenements and estate ownership. The advantages of walking to work over daily endurance of the subway sardine-packing process and the large number of white collar workers in the down-town financial district have inspired this wide-awake body with a vision of the East Side in which the river frontage is to become a series of Sutton Places and its hinterland one vast Tudor City.

This calls to mind that there are two wholly distinct reasons for promoting slum clearance: (1) the health, morals and welfare of the people now living under unwholesome conditions, and along with this goes a benefit

${ }^{3} \mathrm{Mr}$. Veiller has also expressed himself on the need and technique of slum clearance at the last National Housing Conference (Philadelphia, January, 1929) and in the pages of his quarterly, Housing. 
to the whole city on the social side, and (2) increase in real estate values in a blighted area, which entails a certain economic benefit to the whole city. The two should be kept scrupulously separate and not allowed to intertwine. If public money is to be spent or philanthropic coöperation invited for slum clearance, it should be with the first set of aims exclusively in view. So long as we keep them in view, re-housing is an essential part of the process,- - not re-housing for a new set of tenants, but re-housing for the same tenants. This may be on the original site or elsewhere. But unless it meets the needs of these identical tenants, the effort and expenditure have been wasted. When real estate men wish to tear down old houses and put up new ones, to be rented at a commercial profit to economically higher grade tenants, hoping eventually to change the character of the neighborhood and raise its property values, their object is perfectly legitimate. But they should not receive public aid, nor should their project masquerade as one of health and welfare or of benefit to the underprivileged classes.

There is room for both types of enterprise in New York, since its blighted districts are more extensive than the needs of the low-income group who are obliged to remain there. But in so far as the commercial group succeed in rehabilitating any particular neighborhood, they will raise the price of land and make the wage earner's lot within it worse than it is now.

There will be a tendency for commercial projects to attach themselves to the skirts of welfare projects, and this tendency should be energetically and clear-sightedly resisted.

In June 1930 the Housing Association of the City of New York was organized for the improvement of housing conditions, under the presidency of Alfred E. 
Smith, honorary vice-presidents being Felix Adler and R. Fulton Cutting, vice-presidents Alexander M. Bing, Frederic A. Delano, Ruth Pratt and Mary K. Simkhovitch, and the chairman of the executive committee Stanley M. Isaacs. Early in the autumn Edward T. Devine was made executive director. The organization represents widely divergent views as to how the improvement of housing conditions can be brought about and it is still in the formative period of trying to find its soul. It has so far made no pronouncement on slum clearance as such, or as to the part which the city should take in it. It is not without significance, however, that, in its first circular, asking for membership, issued early in 1931, and previously approved by the Board of Directors, it should state that "fortunately ... the essential tasks are already clearly defined" and that among the four such essential tasks it names should be

"(1) Clearing away buildings which are unfit for habitation and cannot be made so-obliteration of black spots;

"(3) Gradual re-housing of the 2,000,000 people who are still living in old-law tenements, such as it has been unlawful to build for the past thirty years."

Perhaps the two most hopeful features in the New York situation are the extent to which the people who live in obsolete tenements have shown that they want to get away from them and the extent to which the owning of such property has become unprofitable. The high percentage of vacancies in the worst of the oldlaw tenements is an indication of the former and a cause of the latter. It has become "socially compromising" to live in a cold-water flat, especially if it is a railroad flat. Unfortunately, hard times and unemployment are tending in the other direction, and pushing families back where rents are cheaper. But if the 
badly-housed people in New York ever get even a halfway clear idea of what they want and even a half-way practicable notion of how to get it, there will be something doing, for they control about a third of the votes. And if the owners of shoe-string equities in old tenements come to realize that they are not going to make fortunes, but may perhaps be saved from bankruptcy, they may eventually be found on the same band wagon.

The interest in slum clearance is not confined to New York and Washington. In the spring of 1930 the American Construction Council held conferences in Chicago and New York on the possibility of launching a national movement for the rebuilding of slum districts. As a result, letters were sent to the Mayors of all large cities and the Governors of all the states suggesting that this be done. It was proposed that slum clearance should be conceived and carried out strictly as a part of city and regional planning. It was further suggested that rebuilding should be carried on with the cordial cooperation of, but not by, the municipal authorities, and on the other hand that it must be on a non-speculative basis. Limited dividend corporations were mentioned as the probable best solution."

These proposals have been strongly advocated by The American City, and in other responsible quarters for their own sake and as a means of relieving unemployment and starting industry to moving. They were inspired by suggestions of Governor Franklin D. Roosevelt in an address to the New York Board of Trade.

"See 5-page leaflet, "The Rebuilding of Slum Districts," Preliminary Report of the Special Committee of the American Construction Council, June 1, 1930. (Can be obtained from the Council's office, 28 W. 44th St., New York.) See also Harold Riegelman's proposal for a 10-year slum clearance plan in New York in connection with the State Board of Housing in the Feb. 1931 issues of the Real Estate Magazine and Better Times. 


\section{CONCLUSION}

We have arrived at the end of our survey of the last fourteen years of American housing. The net result of accomplishment is hardly one to justify a high degree of optimism. The progress inaugurated by the Government's high standards in war housing was wiped out by the post-war years of housing shortage accompanied by congestion, lack of repairs, and generally lowered standards. As already stated in Chapter II, it took us ten years or thereabouts, to get back to the point from which we had started. Most of the old houses which were sub-standard at the beginning of the period, were still in existence at the end, ten years older, and in a much worse state of repair. The new houses built showed advances in comfort and convenience. For the top economic third, housing standards have undoubtedly risen. This is what responsible Americans presumably mean when they talk about our housing standards being the highest in the world.

So far as the other two thirds of the population are concerned, compared with the rest of the world, we have lost ground. If Europe was a generation ahead of us in her attitude toward the housing problem at the war period, the distance is greater now. Great Britain's and Germany's huge building accomplishment for the lower income groups, measured by the million families, and Holland's, which has provided for one fifth of her people, have already been mentioned. France is carrying out a five-year program for 250,000 working-class homes. Britain is just starting on a vast nation-wide slum clearance effort. And we are still thanking God 
that we are not as other men are and that we do not interfere with the sacred laws of supply and demand in the matter of providing homes for those who need them. ${ }^{1}$

By far the largest amount of American housing progress in the past fourteen years has been made in zoning and in the adjoining field of city and regional planning. This line of advance is preventive of bad conditions in the future and highly desirable to secure. At the same time, progress along the lines of the earlier-developed restrictive housing law of the Veiller type has been completely-and in the writer's opinion regrettably-arrested.

With some years of energetic residential building for the top economic third of the population, those less fortunate have fallen heir to some of the dwellings vacated by those who moved into new ones. The amount of limited dividend housing provided directly for them has been negligible in relation to the total, though interesting in itself in some instances. Even in New York City, where it has received much more attention than anywhere else in the country, it has produced in the post-war years accommodations for about 6000 families, which is almost exactly $1 \%$ of what has been produced during the same period by private business initiative with the profit motive, for the top economic third. Even limited dividend housing has not reached, except in sporadic cases, those in the lowest economic third of the population. Yet each American business man who becomes interested repeats the experiment of trying to cater to them on the basis of a 5 or $6 \%$ return

1 The writer has wondered, when told the American workingman is too proud to live in a home which has received any sort of government assistance, even that of a mortgage loan, why the American farmer does not consider himself humiliated by the Farm Loan Bank, why the American owners of steamship lines do not protest against subsidy, or how the American manufacturer can bring himself to accept the aid of a protective tariff. 
on his investment without tax exemption or other subsidy. None of them has pursued the experiment farther than proving that the really low income groups cannot be built for in this way. On the economic side, each begins again at the beginning. None of them has shown any disposition to profit by European experience and few have studied it. Most of the efforts to secure state loans for housing, or municipal participation in building have been ill-advised or weakly supported and have come to nothing, or have been used on so small a scale as to have little significance. Nothing that can properly be called slum clearance has yet taken place. The housing shortage brought about sporadic rent restriction and anti-eviction legislation, the most effective being in the District of Columbia and in New York City, which it took some years to get rid of. It also brought about temporary tax exempton on new residential construction in New York City, which resulted in a large volume of building for the top economic third and a large amount of profit for the speculative builders. This negative subsidy has cost the New York tax-payers a great deal more than London has paid for her "assisted" working-class housing.

So much for the negative side. But some things have happened which have helped. The checking of immigration has simplified our problem, because the yearly flood of strangers willing to live anywhere, anyhow, and quite unable to protect themselves from exploitation made the worst sort of old housing profitable. On the other hand, as will be seen later, this same halting of immigration may be indirectly responsible for a great evil. The added purchasing power of the Ameri-

2 The writer does not recall any protest from New York builders against the humiliation of this "dole." Perhaps they accepted it in a spirit of altruism to spare the working people from having it forced on them? 
can wage has helped-18\% or whatever it may precisely be. There has been progress in community and neighborhood planning, especially exemplified in Radburn. There has been progress in apartment house design, thanks primarily to Andrew J. Thomas. There has been a real beginning in coöperative housing, though it is safe to say it will not get very far without state loans or the equivalent. There is presumably to be in the President's Conference on Home Ownership an opening up of the problem of home financing. There is persistent talk of slum clearance which may some time produce action. There is a growing interest in municipal housing as a thing not desired, but perhaps offering the only way out. There are an increasing number of people aware that something interesting is taking place in a number of European countries in connection with the homes of their people.

Above all, there are the two activities which have already been called the outstanding housing achievements of the American post-war period,-activities which have not only been successful in themselves, but which carry with them the possibility of great expansion and great development. They are only first steps, but they are in the direction in which progress lies-the only direction in which it can lie except by economic revolution. Since the 1930 Census puts the population of California at 5,672,000 and that of New York City at $6,930,000$, and since the housing of California veterans with state assistance had passed the 7500 mark on June 30,1930, whereas all the post-war limiteddividend housing in New York, built or building at that time, did not reach $5700,{ }^{3}$ it is evident that California

${ }^{8}$ This figure excludes coöperatives except such as have been built under the state housing law. If they were included, the figure would still be under $\mathbf{7 5 0 0}$. 
takes first place, absolutely and relatively, in volume of accomplishment. On the other hand, the large number of experiments in New York, independent of each other, probably indicates a more widely diffused interest.

Some day America will inevitably awake to the cost of bad housing. The wanton wastefulness of it will trouble the American sense of efficiency. As the progressive manufacturer ruthlessly scraps obsolete machinery, though it represents a large investment of capital, so will the up-to-date town systematically scrap its obsolete dwellings. Of course, the task is colossal. If, as we claim, a third of our American homes are bad enough to be demolished, that would involve the building of some nine million new ones. With standardization, quantity production, and the use in some places of multiple dwellings, it is possible that it could be done at an average cost of about $\$ 4000$ per family, or some 36 billion dollars, or when we add the excessive price which would probably be paid for some slum property, let us say 40 billion. It is pretty appalling of course. But look at the other side.

How much do our obsolete dwellings cost us yearly in preventable deaths, sickness and crime? The question is asked in a purely economic sense. Human happiness and human misery cannot be weighed in such scales. But we can learn considerable without leaving the practical field of dollars and cents.

The Australian Year Book has assembled national death-rates for the year 1926-the last one for which all the data could be obtained. ${ }^{4}$ Countries ranking be-

4 The figures in the Australian Year Book are crude rates. The actuary of the Prudential Insurance Company recently prepared standardized rates for five-year periods, ending in 1925, which do not seriously differ from the Australian table. Neither Uruguay nor Germany ranked at that time above the United States, but Switzerland did. 
low the United States are omitteu for the sake of brevity. The higher ones are as follows:

\begin{tabular}{|c|c|c|}
\hline 1. New Zealand & 8.7 & per 1000 \\
\hline 2. Australia & 9.4 & " \\
\hline 3. Netherlands & 9.8 & “ \\
\hline 4. Norway, & 10.9 & “ \\
\hline 5. Denmark & 11.1 & “ \\
\hline 6. Canada & 11.4 & " \\
\hline 7. England and Wales & 11.6 & " \\
\hline 8. Sweden & 11.8 & “ \\
\hline 9. Uruguay & 11.8 & " \\
\hline 10. Germany & 11.9 & " \\
\hline 11. United States & 12.1 & “ \\
\hline
\end{tabular}

Why are we so far down the list? Is it poverty? ignorance? density of population? bad climate? Or is there some public health policy which they follow and we do not? Housing is the answer. Ours is the only one among these nations which considers it no concern of the community that a third of its families live in homes which lower their resistance to disease and multiply their chances of infection. Germany used to have a high death-rate, before the War as well as since. She used to house the bulk of her working classes in one and two-room tenements, many of them inadequately lighted. She has greatly improved that situation and is already reaping her reward. That she has had greater difficulties to overcome than we would encounter is hardly debatable. Holland has an exceedingly dense population. England is carrying a twelve-year burden of large-scale unemployment.

Some of our statisticians have been saying recently that we must not expect much further diminution of death-rates, that, on the contrary, they are liable to increase as the age proportion of the population changes. Our great gains have been in reducing infant mortality. More babies than formerly grow up. There has been no gain in expectation of life at the age of fifty. As 
more and more people reach middle life, death-rates will become higher, they say.

It would seem fairly obvious that we should study the death-rates which have been actually attained in other countries before deciding that we have already reached the minimum. Standardizing them for age does not alter their message. If New Zealand can keep her death-rate down to $8+$ per thousand, we should surely not be content in the United States with $12+$. If densely populated Holland can get below 10 and debtburdened England and Germany lose only 11 and a fraction, should we not feel humiliated at losing 12 ?

A difference of one per thousand in a population of 122 million, means the loss of 122,000 lives a year, which might be saved if we were willing to take the trouble. At the rough-and-ready figure of $\$ 5000$ per life, that means a yearly financial loss to the nation of $\$ 610,000$,000 . On the basis of the difference between the New Zealand death-rate (8.7) and that of the United States (12.1), we are sustaining a needless yearly loss of 415,000 lives, whose economic value would be considerably over two billion dollars.

Death-rates, however, tell only a part of the story. Only a small fraction of illness results in deaths, but all illness involves financial loss. When the Committee on the Cost of Medical Care in the United States completes its work, we shall doubtless have more precise information. It has already issued a preliminary report on the "Extent of Illness and of Physical and Mental Defects prevailing in the United States," Alden B. Mills, November 1929. From it we learn that the average man is absent from work 7 days a year because of illness, the average woman 8 days, while the average school child misses 10 days from school for the same reason. That accounts for about half of the popula- 
tion. Concerning the other half, there is no available information, but their amount of illness is probably similar. The cost includes wages lost and money spent for doctors, hospitals or medicines. It involves also the loss to industry or office where a worker who was expected and planned for does not appear and the waste at school when the child does not receive the instruction for which the tax-payers are paying.

According to Dr. Ray Lyman Wilbur, who is chairman of the Committee on the Cost of Medical Care (in a statement to the press May 22,1928), the "cost of illness to the people of the United States is probably more than five billion dollars a year." Some estimates have been nearly twice as high. It is generally roughly assumed that half of the existing illness is preventable. Judging by reports from manufacturers at the Garden City of Letchworth, the excellent housing conditions under which unskilled and semi-skilled as well as skilled workers live there have reduced absence from work because of illness to much less than one half. Assuming, however, that only half of existing illness is preventable, and taking Dr. Wilbur's low total, we should have two and a half billion dollars as the annual loss from this source.

Our third great national waste is crime. Commissions innumerable have tried to find out how we attained our bad eminence in this respect. We are shown that conditions of law-breaking have existed for a long time, but that with us they have grown worse, while in other countries they were growing better. In 1904 England had a prison population of 20,000. Now it is about 7000. A hundred years ago she had 250 local prisons, now only 33 . Our thirty-one times as high homicide rate has become painfully familiar. The most striking feature, perhaps, is that during the post-war years, 
while England has been suffering from continued business depression and unemployment, which would be expected to produce an abnormal amount of crime, she has been growing more and more law-abiding, and we, with unprecedented prosperity most of the time, have been traveling in the opposite direction.

The situation is complex. Not one cause, but many are doubtless at work. Writers blame it, according to their own outlook, on prohibition or increased divorce or the breakdown of religion or the prevalence of this or that racial group. The racial explanation has received a considerable blow from Dr. Clifford R. Shaw's recent studies in Chicago, where he plotted the addresses of 60,000 truants, delinquents and criminals on a map of the city for thirty years and showed that the Loop and other areas of bad housing were always the areas of bad conduct whatever racial group inhabited them. Racial groups moving to better areas improved in conduct. The latest immigrant wave always drew the worst housing and became the worst behaved.

Several things our numerous crime commissions and studies seem to have established fairly conclusively.

1. The customary sequence between truancy, delinquency and crime. Most criminals have been juvenile delinquents. Most delinquents have a previous history of truancy.

2. These groups have more than their proportionate share of mental defectives, but they appear to contain an overwhelming proportion of the emotionally unstable.

3. Nearly every study recognizes the coincidence between bad housing areas and juvenile delinquency. It has frequently been said that $90 \%$ of juvenile delinquents came from physically bad homes.

The Crime Commission of the State of New York pub- 
lished a "Study of Environmental Factors in Juvenile Delinquency" in 1928. The first of its four recommendations read: "Housing. The relation of bad housing to delinquency has been clearly indicated in this study. Every effort should be made by the authorities to speed a housing program of broad scope, that will replace oldlaw tenements with modern structures. Private individuals should also be encouraged to participate in this housing program, as one progressive step in delinquency prevention." As the report truly says "Home life cannot take place unless there is actually a home in which it may take place." It points out that the five blocks productive of the greatest amount of juvenile delinquency in 1926 were blocks of bad housing construction or bad sanitation or both. In these blocks 161 out of 175 tenement buildings are old-law structures, $80 \%$ of them with rooms whose only light and air comes from partition windows to adjoining rooms. "In four small blocks of wretched housing, under an elevated structure, 58 boys and girls, or nearly five times the average for the area, were reported as conduct problems during 1926."

This last statement suggests the noise factor and its effect on the child's nervous system, which the present writer believes has never received sufficient attention.

Dr. Shirley W. Wynne, Commissioner of Health of the City of New York, in the Report of the Noise Abatement Commission appointed by him (1930, p. 215) makes the following profoundly significant statement:

"I venture to say that in crowded sections of our city are children who never know a moment when their ears are not bombarded by noise. In the light of what has been discovered about noise and the fear reaction, it would seem that these children must be constantly keyed to a fighting pitch. This seems especially signifi- 
cant to me when I consider the increase of the gangster type in the last twenty years. As far as I know, no study has ever been made along these lines. But, if we could only make a study of this phase of the question -and in time we shall-I am confident the facts would be very revealing."

One of the studies made for the Noise Abatement Commission was by Dr. Foster Kennedy, neurologist at Bellevue Hospital, and showed that the explosion of a paper bag increased pressure on the brain to four times normal for seven seconds, with thirty seconds needed for recovery. Hypodermic injections of morphine and nitro-glycerine, the most powerful known agents for raising brain pressure, produced less effect.

Dr. Arnold H. Kegal, Commissioner of Health of Chicago, calls noise a health hazard. He says that noises not sufficient to wake a sleeping person will cause muscles to become tense for periods as long as thirty minutes. Sleep under such conditions is not satisfying. People wake up feeling tired. He says that scientific research has proved that it requires $19 \%$ more energy to perform given duties in a noisy location than in a quiet one.

Most of the discussions of noise have centered about street noises or factory noises. But Dr. Wynne's remarks would indicate his awareness that there is nothing more continuously or irritatingly noisy than a tenement house. It contains too many people, and many of them are conspicuously lacking in reticence. The partitions are too thin. The courts are too narrow. When windows are open in warm weather, every noise in every room of two adjoining six story tenements is shared by all, whether it is a baby crying, a child being punished, a drunkard falling over a chair, or a man and 
woman quarreling. There is no such thing as quiet in the whole twenty-four hours.

Now if there is any one thing the health authorities are agreed on, it is the need of young children for quiet, undisturbed sleep. As Dr. D. A. Thom says in "Everyday Problems of the Everyday Child," "A well regulated routine life for a child is absolutely essential to his physical and mental welfare." $\mathrm{He}$ especially recognizes the impossibility of providing proper sleeping quarters for children in a four-room tenement (one, two or three rooms are not even mentioned) and says the situation demands the attention of social and governmental agencies.

This is the place to recall that while immigrants were pouring into the country unrestrained, each new wave displaced the last one in the worst of the tenements. When immigration was checked, the last wave stayed where it was. It is only in the past few years that we have seen boys and girls who were born in our slums come to maturity in the same ugly surroundings, with small likelihood of getting away from them except for the gifted few-or by the easy short-cut of crime. May this not be one among the causes of our recent crime epidemic?

The growing up of a generation born and bred in the older tenements is probably, however, linked more closely with the sudden outburst of crime in another way than in the one just mentioned. Criminals and delinquents, whether mentally subnormal or above average intelligence, are disproportionately characterized, as has been said, by emotional instability. To a very large extent, they are also products of tenement house homes. Is this a mere coincidence, or do parents of the unstable type, because of low earning power, gravitate to the poorest housing, or do tenement houses 
tend to produce emotional instability? The last two hypotheses are by no means mutually exclusive, but only the last offers an explanation of a sudden recent crime increase or of why it should be present in New York and absent in London. It would be of great importance to find out whether the noise and congestion of the tenements, affecting the child from the moment of birth, after affecting the mother during pregnancy, do produce emotional instability.

Psychologists tell us that children are not born emotionally unstable, but with a nervous condition which favors their becoming so. Dr. Thom, in his "Mental Health of the Child," describes this predisposing condition as one of exaggerated reaction to stimuli either from within or without. Such an infant's first troubles are with eating, sleeping and elimination. It does not adjust itself as the ordinary child does to its environment. It develops peculiar mannerisms, tics and convulsions. It has far more than its share of crying, temper tantrums and negativistic reactions. Such a child, though mentally bright, does not show normally good judgment in weighing consequences when selecting a line of conduct. In other words, here is the material from which delinquents and criminals are made. The treatment for such cases must be applied very early indeed to be hopeful. It consists chiefly of physical and spiritual quiet, abundant sleep and fresh air,-precisely the things which the tenement child can not get.

There would seem to be room here for some exceedingly fruitful research.

Returning from our detour to establish closer connection between crime and housing, we shall have to admit that estimates so far made of the amount of our annual crime bill vary so greatly as to make them of little practical value. Apparently responsible figures 
run from 3 to 20 billion dollars, 12 billion being a fair average. Such figures include the cost of maintaining police, courts, jails and reform schools, as well as damages to person and property, and the vast amount of loot stolen, embezzled or obtained by counterfeiting, forgery or fraud.

While fully admitting the provisional character of the available figures, we feel little doubt that the truth lies somewhere between the extremes offered in the following table as indicating the pecuniary saving that would be effected annually by tearing down our nine million worst homes and building the same number of good ones.

By reduction in number of deaths, from 1.5 to 2 billion dollars By reduction in amount of illness, from 1.25 to 2.25 billion dollars By reduction in amount of crime, from 1.5 to 10 billion dollars

Total saving, from 4.25 to 14.25 billion dollars

That $40^{5}$ billion dollars which looked so hopelessly vast when we spoke of it a few pages back does not seem so formidable now, for we see how we could save it in from three to ten years, and all after that would be clear profit. If the cost of that gigantic slum-clearance and re-housing scheme were all borne by the tax-payers as in the case of the public schools,- - which no one would dream of suggesting,-if it were all out-go and no income, it might still be the best investment the country ever made. For the first time since we got away from the pioneer stage, it would give every American child something like an even break to show the stuff that was in him.

The American Construction Council should not per-

${ }^{5}$ The American Construction Council leaflet, already quoted, speaks of a probable expenditure of 50 to 100 billion dollars in the 10-year program they advocate. The two ideas are not, however, precisely comparable. 
mit its proposal of a ten-year nation-wide program of rebuilding slum districts to be forgotten or pigeonholed. It is much more economically sound as a means of ending unemployment than the accepted multiplying of public expenditures for roads and post office buildings which we could perfectly well do without for a while. It is, in fact, the most statesmanlike proposal yet made for turning hard times into good ones. One of the factors that brought prosperity back to France after the War was that until the Devastated Regions were rebuilt there could be no unemployment. Can we not have vision enough to re-build our Devastated Regions without waiting for a war to destroy them?

Wanted: A Major Statesman to make Housing on the Grand Scale the chief plank in his platform. 



\title{
BIBLIOGRAPHY
}

\section{References Dealing with the United States}

\author{
PRE-WAR PERIOD
}

\section{Books of General Interest}

"How the Other Half Lives", Jacob A. Riis, 1890

"The Housing of the Working People", E. R. L. Gould, Eighth Special Report, U. S. Commissioner of Labor, 1895. (A general survey of great value)

"Ten Years' War", Jacob A. Riis, 1900

"The Battle with the Slum", Jacob A. Riis, 1902

"The Tenement House Problem", Robert W. de Forest and Lawrence Veiller, 1903. (Contains report of the Tenement House Commission of 1900 and other interesting documents)

"Housing Reform", Lawrence Veiller, 1910. (Statement of the Veiller philosophy of housing)

"Beauty for Ashes", Albion Fellows Bacon, 1913. (Story of the winning of the Indiana State Housing Law by the woman who did it)

"A Model Housing Law", Lawrence Veiller, 1914, 1920. (Still the best guide in drafting a restrictive housing law)

"The Housing of the Unskilled Wage Earner", Edith Elmer Wood, 1919

Reports and Surveys

U. S. Bulletin of Labor, Vol. IX, No. 54, 1904, Housing of Working People in the United States, G. W. W. Hanger

U. S. Department of Labor, Children's Bureau, Infant Mortality Studies:

Johnstown, Pa., 1915.

Montclair, N. J., 1917

Manchester, N. H., 1917

Housing Problems in America, (Proceedings of the National Housing Association) from 1911 
National Housing Association, Various pamphlets.

Tenement House Legislation, State and Local, F. H. MacGregor, 1909

Housing Problem, A Summary of Conditions and Remedies, James Ford, 1911

Baltimore

Housing Conditions in Baltimore, Janet E. Kemp, 1907

Boston

Tenement House Census, Massachusetts Bureau of Labor Statistics, 1891

Report, Commission to Investigate Tenement House Conditions, 1903-4

Report, Housing Committee of the Boston 1915 Movement, 1910

Report, Women's Municipal League, 1916

Report, Mayor's Committee on Housing, 1919

Bridgeport, More Houses for Bridgeport, John Nolen, 1916

California

Commission of Immigration and Housing, Reports. From 1915 Chicago

Studies by Breckinridge and Abbott, Comstock and others, relating to 29th Ward, West Side, Steel Mills district, Italian districts, housing of Negroes, etc, 1910, 1911

Report, Chicago's Women's Club, Tenement Housing Conditions in the Twentieth Ward, 1912

Report, Chicago School of Civics and Philanthropy, Housing Problems in Chicago, 1915

Cleveland

Department of Public Welfare, Investigation of Housing Conditions of Cleveland's Workingmen, 1914

Columbus, $\mathrm{O}$.

Report on Housing Conditions, Otto W. Davis, 1910

Des Moines

Report, Housing Commission of Des Moines, 1917

Fall River

Housing Conditions in Fall River, Carol Aronovici, 1912

Grand Rapids

Report on Housing Conditions, Udetta D. Brown, 1913

Kansas City

Report on Housing Conditions in Kansas City, 1912

Massachusetts

Massachusetts Homestead Commission, Reports, from 1912 Michigan

Report Michigan Housing Commission, 1916

Minneapolis

Report Civic and Commerce Association, Housing Problems in Minneapolis, Otto W. Davis, 1914 
New Haven

Housing Conditions in New Haven, Carol Aronovici, 1913

New York

Report of the A. I. C. P. on the Sanitary Condition of the Laboring Classes, 1853

Report of the Legislative Committee of 1857

Report of the Council of Hygiene and Public Health, 1865

Report, Tenement House Commission of 1884

Report, Tenement House Committee of 1894

Report, Tenement House Commission of 1900

Reports, Tenement House Department, from 1902-3

Report Commission on Congestion of Population, 1911

Philadelphia

Reports of the Octavia Hill Association, from 1896

Reports of the Philadelphia Housing Commission, from 1910

Good Housing That Pays, F. L. Waldo, 1917. (An account of the activities of the Octavia Hill Association)

Pittsburgh

The Housing of Pittsburgh Workers (Pittsburgh Survey), E.

W. Dinwiddie and F. E. Crowell, 1914

Providence

The Houses of Providence, John Ihlder, Madge Headley and Udetta D. Brown, 1916

Richmond

Housing and Living Conditions in Neglected Sections of Richmond, Gustavus A. Weber, 1913

Saint Louis

Housing Conditions in Saint Louis, Charlotte Rumbold, 1908

San Francisco

Reports of the San Francisco Housing Association

Springfield, Ill.

Housing in Springfield, Ill. (Springfield Survey), John Ihlder, 1914 Texas

Housing Problems in Texas, G. W. Briggs, 1911

Washington

Report of the President's Homes Commission, 1908

POST-WAR PERIOD

Books of General Interest

"Housing Problems in War and Peace", F. L. Ackerman, C. H. Whitaker, R. S. Childs, E. E. Wood and others, 1918. (Reprints from the Journal of the American Institute of Architects)

"The Joke about Housing", Charles Harris Whitaker, 1920 
"The Housing Famine", Frederick L. Ackerman, Edith Elmer Wood and John J. Murphy, 1920

"Housing and the Housing Problem", Carol Aronovici, 1920

"The New Day in Housing", Louis H. Pink, 1928

\section{Reports and Surveys}

International Labor Office, Housing Situation in the United States, Leifur Magnusson, 1925

Report of the United States Housing Corporation, Henry V. Hubbard, Editor, 2 vols., 1919

Report of the Housing Division, Emergency Fleet Corporation, to the Senate, A. Merritt Taylor, 1919

Report of the Calder Committee to the Senate, March 1921

U.S. Dept. of Labor, Bureau of Labor Statistics, Bul. 263, Housing by Employers in the United States, Leifur Magnusson, 1920

- Bul. 437, Cooperative Movement in the United States in 1925, Chap. V, 1927

- Monthly Labor Review, files

- Children's Bureau, Infant Mortality Studies

Waterbury, Conn., 1918

Brockton, Mass., 1919

Saginaw, Mich., 1919

New Bedford, Mass., 1920

Akron, Ohio., 1920

Gary, Ind., 1923

Baltimore, 1923

Causal Factors in Infant Mortality, 1925

Maternity and Child Care Studies

Rural Children in Selected Counties of North Carolina, 1918

Maternity Care and the Welfare of Young Children in a Homesteading County in Montana, 1919

Maternity and Child Care in Selected Rural Areas of Mississippi, 1921

Nutrition and Care of Children in a Mountain County of Kentucky, 1922

Child Labor and the Work of Mothers in the Beet Fields of Colorado and Michigan, 1923

Maternity and Infant Care in a Mountain County in Georgia, 1923

Welfare of Children in Cotton-growing Areas of Texas, 1924

U. S. Dept. of Agriculture

The Farm Woman's Problem, Florence E. Ward, 1920

Nebraska Farm Homes, 1923 (with Agricultural Experiment Station, University of Nebraska) 
The Farmers' Standard of Living, a socio-economic study of 2886 white farm families in selected localities in eleven states, E. L. Kirkpatrick, 1926

U. S. Dept. of Commerce, Bureau of the Census,

Home Ownership in the United States

Dwellings and Families

Selected Farm Expenses

U. S. Dept. of Commerce, Division of Building and Housing

How to Own Your Own Home, 1923

Present Home Financing Methods, 1928

Housing Problems in America. (Proceedings of the National Housing Association)

Housing Betterment, quarterly publication of National Housing Association through 1927

Housing, same from 1928

Better Homes in America, publications

Reports of U. S. League of Building and Loan Associations

Reports, California Commission of Immigration and Housing

- Veterans' Welfare Board, 1928, 1930

Massachusetts Special Commission on the Necessaries of life, from 1920

- Dept. of Public Welfare, Division of Housing and Town Planning, publications

- New York Committee on Housing, Reconstruction Commission, 1920

—_ Commission of Housing and Regional Planning, 19231926

- State Board of Housing, from 1927

Lexington, Ky., Board of Health, Housing Conditions in Lexington, Madge Headley, 1924

Chicago Dept. of Public Welfare, Living Conditions for Small

Wage Earners in Chicago, Elizabeth A. Hughes, 1925

Cincinnati Better Housing League

Philadelphia Housing Association

Reports of the City Housing Corporation, New York, from 1925

Negro Housing in Indianapolis, T. J. Woofter, Jr. Also similar studies by the same author in Dayton, Winston-Salem and elsewhere. A study of Negro housing in Philadelphia has been made by Mrs. Madge Headley Priest, and the Urban League has sponsored several in New York.

Industrial Housing, Morris Knowles, 1920

Industrial Housing, Clinton Mackenzie, 1920

Primer of Housing, Arthur C. Holden, 1927

Zanesville and 36 Other American Communities, Literary Digest, 1927

"Middletown", Robert S. and Helen M. Lynd, Chap. IX, 1929

Rebuilding of Slum Districts, American Construction Council, 1930 


\section{Articles in Periodicals}

Dinosaur Cities, Clarence S. Stein, Survey Graphic, May 1925

The Public Control of House Rents, Marcus Whitman, Journal of Land and Public Utility Economics, July 1925

Improved Housing as a Means of Crime Prevention, James Ford, Annals Amer. Acad. Polit. and Soc. Sci., May 1926

The Statistics of Room Congestion, Edith Elmer Wood, Journal of the Amer. Statis. Assoc., September 1928

The Modern Apartment House, Henry Wright, Architectural Record, March 1929

Minimum Costs for Low-rental Apartments, Alexander M. Bing, Journal of Land and Pub. Util. Econ., May 1929

Congestion and Its Relation to Important Social and Health Problems. S. James Herman, City Health (pub. by Detroit Dept. of Health), July and August 1929

Slums and the City Plan, Edith Elmer Wood, American City, August 1929

Related Subjects including City and Regional Planning and Zoning

U. S. Dept. of Commerce, Division of Building and Housing

A Zoning Primer

A Standard State Zoning Enabling Act

A Primer of City Planning

A Standard City Planning Enabling Act

Planning Problems of Town, City and Region. (Proceedings of the National Conference on City Planning)

"The Law of City Planning and Zoning", Frank B. Williams, 1922

"The Legal Aspects of Zoning", Newman F. Baker, 1927

Zoning, Chamber of Commerce of the United States

"City Planning", John Nolen, 1916, 1929

"New Towns for Old", John Nolen, 1927

"Our Cities Today and Tomorrow", Theodora Kimball Hubbard and Henry Vincent Hubbard, 1929

Survey and Plan of New York and Its Environs, 1929-(12 vols.)

"Mastering a Metropolis", R. L. Duffus, 1930

"Principles of City Planning", Karl B. Lohman, 1931

"Economics of the Household", Benjamin R. Andrews, Chaps. VI and VII, 1923

"House and Home", Greta Gray, 1923, 1927

"Land Planning in the United States", Harlean James, 1926

New York State Crime Commission, Study of Environmental Factors in Juvenile Delinquency, 1928

"Prosperity, Fact or Myth", Stuart Chase, Chap. IV, 1929 


\section{References Dealing with Foreign Countries}

(This list is intentionally brief. Its comparative fulness in British titles is due to the belief that they will have the greatest interest for most American readers)

\section{PRE-WAR PERIOD}

U. S. Department of Labor, Bureau of Labor Statistics, Bul. 158, Government Aid to Home Owning and Housing of Working People in Foreign Countries, 1915. (Contains a wealth of official material)

Proceedings of ten International Housing Congresses, from Paris, 1889 to The Hague, 1913

"Garden Cities of Tomorrow", Ebenezer Howard, 1898

"A Housing Handbook", W. Thompson, 1903

"Housing Up to Date", W. Thompson, 1907

Reports of the Local Government Board. (Chapters dealing with the housing of the working classes)

"Housing of the Working Classes 1855-1912", London County Council, 1913

\section{POST-WAR PERIOD}

International Labor Office, Geneva.

European Housing Problems Since the War, 1924

Methods of Compiling Housing Statistics, 1928

Housing Policy in Europe, 1931

Proceedings of International Housing and Town Planning Congresses from 1920

Bulletins of International Federation for Housing and Town Planning, (headquarters, London)

Publications of International Housing Association, from 1929 (headquarters, Frankfurt a/Main)

"Housing Progress in Western Europe", Edith Elmer Wood, 1923

\section{Great Britain}

Tudor Walters Report, 1918

"Housing and Public Health", John Robertson, 1919

"The Home I Want", Richard Reiss, 1919

Reports of the Ministry of Health, from 1919

"The Housing Problem", John J. Clarke, 1920

"The Betrayal of the Slums", Christopher Addison, 1922 
"The Housing Question", by a Former Housing Commissioner, 1922

"Housing, the Facts and the Future", Harry Barnes, 1923

"National Housing Manual", Henry R. Aldridge, 1923

Supplements to "National Housing Manual", Henry R. Aldridge, 1924 and 1925

"A Handbook of Housing", B. S. Townroe, 1924

"New Housing Handbook", Richard Reiss, 1924

"The Building of Satellite Towns", C. B. Purdom, 1925

"The Housing of the Nation", T. E. Freemantle, 1927

"The Slum Problem", B. S. Townroe, 1928

London County Council, Housing, 1928

"War Against Slums", T. Speake, 1930

"Housing of the Working Classes of Scotland", G. W. Clark, 1930

"Decentralization of Population and Industry", Raymond Unwin and others, 1930

London County Council, Housing, 1931

\section{Germany}

"Wohnungsbau in Deutschland nach dem Weltkriege", Albert Gut, 1928

"Die Wohnungsnot und das Wohnungselend in Deutschland", Bruno Schwan, 1929

Austria

Die Wohnungspolitik der Gemeinde Wien, 1929

Periodicals

Garden Cities and Town Planning, London

Town Planning Review, Liverpool

Housing and Building, Frankfurt a/Main

Zeitschrift für Wohnungswesen, Berlin

L'Habitation à Bon Marché, Brussels

Le Musée Social, Paris

Tijdschrift voor Volkshuisvesting, Amsterdam 


\section{INDEX}

A

Abbott, Edith, 20

Aberdeen, Md., 77

Academy Housing Corporation, 271

Ackerman, Frederick L., 66, 69, 166

Adams, Thomas, 144, 147, 166

Addison, Christopher, 16

Addison Housing Act, 16

Adickes, Franz, 127

Adler, Felix, 85, 281

Akron, Ohio, 22, 99

Alabama, 32

Albany, 102, 103, 104, 117, 118, 143, 244

Allegheny County, Pa., 142, 151

Alliance, O., 77

Altona, Germany, 127

Amalgamated Clothing Workers, $146,188,267,270$

Amalgamated Coöperative Apartments, 173, 178, 179, 180-183, 209, 211, 264-267

Amalgamated Dwellings Inc., 183, 209, 269, 270

Ambler Realty Company, 132

American Association of University Women, 26, 28, 90, 91

American City, 282

American Construction Council, $189,282,296,297$

American Federation of Labor, 77

American Institute of Architects, $77,86,183,225$

American International Shipbuilding Company, 72

American Legion, 253, 257

American Shipbuilding Company, 72

Amsterdam, Holland, 19

Amsterdam, N. Y., 103
Andrews, Benjamin R., 55, 56, 242

Andrews, Lulah T., 80, 81

Arkansas, 30

Atlanta, 99

Atlantic Corporation, 72

Australia, 12, 95, 287, 288

Austria, 93, 96, 97, 98

B

Bacon, Albion Fellows, 8

Ball Rent Law, 99

Baltimore, 5, 22, 37, 99, 126

Barnes, Harry, 7

Bassett, Edward M., 129, 147

Bath, Maine, 72, 77

Bayles Shipyard, Inc., 72

Bayonne, N.J., 221, 222

Belgian General Savings Bank, 13,197

Belgium, 2, 36, 39, 92, 97, 197

Bemberg and Glanzstoff Rayon Companies, 159

Bénoit-Levy, 142

Bergen County, N. J., 166

Berlin, 193

Bethlehem, $\mathrm{Pa}$., 74, 107

Bethlehem Shipbuilding Corporation, 72

Better Housing Building and Loan Association, 190

Bing, Alexander M., 167, 214, 215, 220, 221, 281

Borden Mills, 158

Boston, 4, 5, 22, 99, 101, 114, 126, $135,138,142,228$

Boston City Planning Board, 138, 139

Boston Coöperative Building Company, 11

Boston Metropolitan District, 142

Bournville, 15, 156, 228

Breckinridge, Sophonisba P., 20 
Bridgeport, Conn., 77, 207

Bristol, Pa., 72

British Housing of the Working Classes and Town Planning Act of $1909,127,135$

British Town and Country Planning bill, 128

Brockton, Mass., 22

Bronx (Borough of New York City), 111, 119, 146, 175, 178, 179, 181, 211, 223, 224, 262, 264, 271

Brooklyn (Borough of New York City), 11, 38, 111, 119, 146, 172, $173,174,175,178,208,262,264$, 268, 269

Brooklyn Garden Apartments, 209, 268, 269

Bruce, Roscoe Conkling, 226, 227

Budapest, 93

Budgets (Place of housing in relation to), 53-59

Buffalo, 99, 104, 154

Building and Loan Associations, $39,58,186,189-195,199,256$

Building Materials, 62, 63

Bureau of Industrial Housing. See U. S. Housing Corporation.

Burnham, Daniel H., 136

\section{C}

Cadbury, George, 228

Calder, William M., 198, 199

California, 36, 115, 129, 159, 188, $189,193,194,205,239,246-258$, $259,260,286$

California Commission of Immigration and Housing, 4, 22, 250, 251, 252, 257

California Land Settlement Act, 246-250

California Veterans' Farm and Home Purchase Act, 246, 253$258,259,260,286$

California Veterans' Welfare Board, 60, 239, 253, 254, 255, 256,257

Camden, N. J., 72

Canada, 12, 143, 144, 151, 198, 288

Cawl, F. R., 53
Cellarius, H. F., 191, 193, 194

Census, 27, 28, 30, 31, 37, 50, 88, 286

Chamberlain Housing Act, 16, 106

Chamberlain, Neville, 16, 106, 162

Chamber of Commerce Housing Companies, 206, 207

Charlestown, W. Va., 77

Chellis Austin Apartments (Newark), 245

Cheney, Charles H., 159

Chester, $\mathrm{Pa}$., 72

Chester Shipbuilding Company, 72

Chicago, 4, 20, 53, 99, 136, 137, 180, $211,233-236,282,291,293$

Chicago Women's City Club, 20

Children's Bureau. See U. S. Dept. of Labor

Childs, Richard S., 153

Chrystie-Forsyth Street Clearance, 277, 278

Cincinnati, 12, 142, 164, 165, 193, 207

Cincinnati Better Housing League, 21

City and Suburban Homes Company, 12, 208, 209, 224, 225

City Beautiful, 136, 137

City Housing Corporation, 166, $169,170,175,176,214-221$

City Planning, 135-141, 156, 279, 282, 284

Clark, G. W., 28

Cleary, Charles W., 249

Cleveland, 39, 40, 85, 99, 132, 151

Clyde, Calif., 72

Cohen, Julius H., 203

Cohoes, N. Y., 103, 143, 243, 244

Colorado, 33

Columbia University, 105, 220, 242

Columbus, O., 10

Committee on New Industrial Towns, 153-155, 156

Conference on Home Building and Home Ownership, 185, 189, 286

Congleton, Jerome T., 245

Connecticut, 11, 32, 99, 145

Consumers' Coöperative Services Inc., 184 
Coolidge, Calvin, 101

Coöperative housing, 18, 47, 171$184,223,225,242,243,264,265$, $268,269,270,272$

Coöperative League of the U. S. A., $173,174,175$

Copenhagen, 93

Cornell Heights, $\mathrm{Pa} ., 72$

Council of National Defense, 67, 68

Council of Social Agencies, 53

County Planning Boards, 142

Court decisions, 125, 127, 130, 131, 132, 133, 202, 252

Cram, Ralph Adams, 138

Crime, 290, 291, 294, 295, 296

Curran, Thomas M., 186

Cutting, Robert Fulton, 281

\section{D}

Dark rooms, 4, 5, 19, 288, 292

Dayton, Ohio, 99

Death rates, $19,151,287,288,289$, 296

Deegan, William F., 117

Delano, Frederic A., 144, 281

Delaware, 143

Delhi, Calif., 159, 248, 249, 250

Denmark, 93, 288

Des Moines, 37

Des Moines Housing Commission, 4,19

Detroit, 22, 28, 29, 142, 151

Detroit Shipbuilding Company, 72

Dever, William E., 233

Devine, Edward T., 281

District of Columbia Planning Commission, 142, 274

District of Columbia. See Washington.

Duffus, R. L., 147

Durham, Calif., 159, 247, 248, 249, 250

Dwelling Law, 119, 120

\section{$\mathrm{E}$}

Earswick, 15, 156

Eastriggs, Scotland, 66

Edge, Walter E., 198

Edison, Thomas A., 63
Eidlitz, Otto M., 68

Elizabethton, Tenn., 159

Emergency Fleet Corporation, 68, $71,78,80,82$

Emery, Mary M., 163, 164, 165

Emotional instability, 294, 295

Employers' housing, 20, 21, 156, 206

England. See Great Britain

England and Wales, 16, 17, 18, 28, $40,63,288,289$

English Building Clubs, 190

English standard of housing, 15, $16,18,19,40,41,53,55$

Equitable Life Assurance Company, 197

Erie, Pa., 77

Essington, $\mathrm{Pa}$., 72

Euclid, Ohio (Village of), 125, 132,133

"European Housing Problems since the War," 92-94, 96, 106

Excess condemnation, 275, 276

F

Fairfield County, Conn., 145

Fairlawn Township, N. J., (Radburn), 168, 169

Fall River, Mass., 140

Farband Coöperative Housing Corporation, 179, 209, 268, 269

Farm home loans, 200, 201, 246250

"Farm Woman's Problem," 31, 32

Federal Farm Loan Act, 199, 200, 284

Federal Home Loan Bank bill, $87,197,199,200$

Fiefield, J. H., 196

Finland, 93

Finns in Brooklyn, 173, 174

Flint, Mich., 207

Florida, 159

Ford, George B., 147

Ford, Henry, 62

France, 2, 14, 55, 92, 93, 97, 127, $142,198,283,297$

Frankfurt-am-Main, 127

Fred L. Lavanburg Foundation, $228,229,232$

Fresno, Cal., 99, 250 
G

Garden Cities, 15, 144, 153, 160 $163,165,166,214$

Garden Cities and Town Planning Association, 160, 162

Garden Homes Company (Milwaukee), 176, 177, 241-243

Gary, Ind., 22, 153, 154, 156

General Federation of Women's Clubs, 26, 32

Geneva, 28

George, Henry, 150, 152

Georgia, 33, 34, 37, 123

Germany, 2, 18, 19, 55, 92, 93, 96, $98,127,142,152,153,283,287$, 288,289

Glouster, N. J., 72

Glynn County, Ga., 123, 142

G. M. Standifer Construction Co., 72

Goldfeld, Abraham, 231

Gompers, Samuel, 67

Goodrich, Ernest P., 146

Gove, George, 264

Graded tax on land, 150-152

Grand Rapids, 37, 191

Great Britain, 2, 15-18, 19, 66, 92, $97,106,113,135,142,144,152$, $153,160-163,198,283,290,291$

Gretna, Scotland, 66

Gries, John M., 128, 186

Groton, Conn., 72

Groton Iron Works, 72

\section{HI}

Haig, Robert Murray, 153

Hamburg, 127

Hamilton County, O., 142

Hammond, Ind., 77

Happy Valley, Tenn., 159, 160

Harder, Frank J., 242

Hartman, Edward J., 140

Hauszinsteur (German rent tax), 18

Haynes, Fred. E., 240

Hayward, Calif., 250

Headley, Madge (Mrs. Priest), 20

Heckscher, August, 266, 267, 271, 275-278
Helsingfors, 93

Hennessy, Chas. O., 199

Herman, S. James, 28, 29, 204, 205, 239

Hershey, Pa., 156

Heydecker, Wayne D., 146, 147

Hillman, Sidney, 180, 266, 270

Hill, Patty Smith, 220

Hiss, Philip, 67

Hoan, Daniel W., 177, 241, 242, 243

Holland, 2, 19, 27, 92, 113, 283, 288,289

Holyoke (Mass.), National Bank, 196

Home Index, 28

Home ownership, 27, 35-39, 47, $55-59,151,185-189,201,204$, $205,215,216,217,244,250,251$, 252, 253-258, 259

Hook-worm, 6, 29, 30, 35

Hoover Committee on the Elimination of Waste in Industry

Hoover, Herbert, 43, 61, 90, 128, $185,189,199,277,286$

Houghteling, Leila, 53

Housing Betterment, 132

Housing by public authorities, $13,14,15,16,17,18,19,21,64$, $67-82,102,161,237-258,285$

Housing Division of Fleet Corporation. See Emergency Fleet Corporation

Housing loans, 13, 14, 102, 113, 172, $173,185-205,260,272,285$

"(The) Housing of the Unskilled Wage Earner," 8, 10, 66, 114, $139,190,195,201,206,228,238$

Housing shortage, 21, 22, 38, 83$94,95,96,198,250,283,285$

Howard, Sir Ebenezer, 15, 162

Hubbard, Henry V., 74

Hudson, Ray M., 62

Hughes, Elizabeth A., 20, 233

Hungary, 93

Hyde, Arthur M., 51

Hylan, John F., 117

\section{I}

Ignaciunas, 131

Ihlder, John, 152 
Illinois, 114, 129

Illness, amount and cost of, 289, 290,296

Income of families, 47-52, 53, 212, $219,227,230,233,236,267$

Indiana, 193, 194

Indianapolis, 22

Indian Head, Md., 77

Industrial Survey and Research Service, 26

Infant Mortality, 22, 23, 24, 29, 151

Ingersoll, C. J., 63

International Housing and Town Planning Exhibition, 193

International Labor Office, 28, 92

Iowa, 32, 114, 116, 119

Iowa State Housing Law, 20, 114, 116

Isaacs, Stanley M., 281

Italy, 92, 93, 97

\section{J}

Jackson Heights, 171

Jacksonville, Fla., 72

James, Darwin R., 264, 271

Japan, 13

Jenkins, J. Caldwell, 68, 79

Jersey City, 99

Jewish National Workers Alliance of America, 179, 268

Jewish National Workers' Cooperative Homes Association, 179,183

Johnson City, Tenn., 159

Joint Tenant Ownership, 171, 172 Journal of Land and Public Utility Economics, 99

Journal of the American Institute of Architects, 66, 86, 153

Juvenile delinquency, 29, 291, 292, 294

\section{K}

Kansas, 32, 129

Kansas City, 22, 37

Kazan, A. E., 181, 182, 183, 270

Kegal, Arnold H., 293

Kennedy, Foster, 293

Kenosha, Wis., 207
Kentucky, 29, 32, 33, 115

Kenyon, William S., 198

Keppel, Frederic P., 144

Kern, Robert R., 142

King, W. I., 3, 48, 51

Kingsport, Tenn., 157, 158

Kirkpatrick, E. L., 32

Kistler, $\mathrm{Pa}$., 157

Kohler, Wis., 157

Kohn, Robert D., 166

\section{$\mathrm{L}$}

Lackawanna, N. Y., 154

La Guardia, Fiorello H., 278

Land Bank of the State of New York, 87, 197, 200, 203

Land values, $61,102,119,149-155$, $156,161,165$

Lavanburg Homes, 209, 228-232

League of Mothers' Clubs (New York), 52, 224

Lebaudy Foundation, 228

Lehman, Herbert H., 270

Leitner, Jacob, 271

L'Enfant, Pierre Charles, 136

Letchworth Garden City, 15, 144, $160,161,166,290$

Leven, Maurice, 27

Lexington, $\mathrm{Ky}$., 20

Limited dividend companies, 11 , 64, 112, 206-236, 245, 261-273, 282,284

Lindsay, Samuel McCune, 105

Literary Digest, 25

Liverpool, 111

Livingood, Charles J., 164

Lloyd George, David, 16

Lloyd George Housing Act. See Addison Housing Act

Lockwood Committee (New York State), 86, 87, 101, 210

Loeb, Sophie Irene, 277

London, 111, 160, 228, 285, 295

Long Beach, Calif., 250

Long, Howard, 157

Long Island, 145

Longview, Wash., 158

Lorain, Ohio, 72

Los Angeles, 22, 99, 126, 142, 158, 250, 251, 252 
Los Angeles Housing Commission, 251, 252

Louisiana, 30, 239, 240

Louisville, 115

Lowell, Mass., 140, 239

Lower East Side, 88, 183, 208, 229, $269,271,279$

Lucas County, Ohio, 142

Lynd, Robert S., and Helen M., 24

\section{M}

Mackenzie, Clinton, 157

MacPherson, Hector, 200, 201

Magnusson, Leifur, 20

Maine, 99

Manchester, England, 111

Manchester, N. H., 22

Manhattan (Borough of New York City), 37, 111, 119, 136, 144, 146, 175, 262

Manhattan Housing Corporation, 271

Manitowoc Shipbuilding Company, 72

Manitowoc, Wis., 72

Mare Island, Calif., 77

Mariemont (Cincinnati), 153, 163-165, 166, 167

Marquette, Bleecker, 163

Marshall Field Garden Apartment Homes, 234

Massachusetts, 32, 99, 101, 114, $129,130,139,140,141,189,193$, 238, 239

Massachusetts Department of Public Welfare Division of Housing and Town Planning, 140

Massachusetts Homestead Commission, 139, 140, 238, 239

Massachusetts Special Commission on the Necessaries of Life, 101

McAneny, George, 128

McDowell, Mary E., 20, 233, 234

Mead, Elwood, 247

Mead, William, 251, 252

Medical Care in the United States, Committee on the Cost of, 289,290
Mediterranean coast regional plan (France), 142

Mercer County, N. J., 142

Merchants Shipbuilding Company, 72

Merrill-Stevens Shipbuilding Co., 72

Metropolitan Life Insurance Co., 158, 209-214, 218, 219, 265, 271

Mexicans (housing of), 20, 29, 233

Michigan, 33, 114, 119, 129, 204, 205

Michigan Boulevard Garden A partments, 235, 236

Michigan Housing Association, 204, 205, 239

Michigan Housing Commission, 4

"Middletown," 24

Milan, 93

Mills, Alden B., 289

Milwaukee, 99, 173, 176, 177, 205, 241-243

Milwaukee County, Wis., 142

Minimum standard of housing, 39-43, 69-71

Minneapolis, 114

Mississippi, 30, 32, 33, 34, 48

Missouri Valley D. and I Co., 72

Model Homes Company (Cincinnati) , 12, 207

"Model Housing Law," 114, 116

Monroe County, N. Y., 142

Montana, 33, 34

Montclair, N. J., 22

Montgomery and Prince George Counties, Md., regional plan, 142

Morals and housing, 6, 7, 85, 198

Morgan Park, 156

Mount Union Refractories Co., 157

Muncie, Ind., 24

Municipal housing. See Housing by public authorities

Mutual Savings Banks, 195

\section{$\mathrm{N}$}

National Bureau of Economic Research, 47

National Conference of Charities and Correction, 39 
National Conference of Social Work, 195

National Conference on City Planning, 137

National Housing Association, $10,68,69,76,100,114$

National Housing Committee for Congested Areas, 277

National Industrial Conference Board, 55

Nebraska, 30, 31

"Nebraska Farm Homes," 30

Negro housing, 5, 9, 20, 29, 33, 34, $35,38,54,158,224-228,233,234$, 235,236

Nevada, 99

Newark, 99, 214, 244-246

New Bedford, Mass, 22, 140

New Brunswick, N. J., 77

Newburgh, N. Y., 72

Newburgh Shipyard, Inc., 72

New Castle, Del., 77

New England, 30, 32

New Hampshire, 32

New Jersey, 10, 99, 107, 129, 130, $131,143,145,167,169,244-246$

New Jersey League of Municipalities, 131

New London, Conn., 77, 99

Newman, Bernard J., 33, 38, 44, $46,57,190$

Newport News, Va., 72

Newport News Shipbuilding Company, 72

Newport, R. I., 77

New York City, 4, 5, 10, 21, 41, $49,52,53,64,85,86,87,88,101-$ $105,106-112,116-121,124,128$, $130,136,138,145,146,151,152$, $166,167,171,174,175,180,183$, 188, 208-232, 259-273, 274-282, $284,285,286,287,292,293,295$

New York Commission of Housing and Regional Planning, 21, $64,87,105,108,109,110,111$, $112,143,144,202,260,264,278$

New York Evening World, 21

New York Herald-Tribune, 194

New York, Housing Association of the City of, 280, 281

New York Multiple Dwelling Law, 116-121
New York Regional Plan, 5, 143, 144-148, 279

New York Regional Plan Association, 147, 279

New York Shipbuilding Company, 72

New York State, $33,37,48,53,86$, $99,101-105,129,143,145,197$, $200,202,243,244,259-273,275$, 291,292

New York State Board of Housing, 21, 88, 104, 105, 109, 111, $112,173,179,180,181,210,259$ 273,277

New York State Crime Commission, 291, 292

New York State Housing Law of $1926,107,112,173,178,204,209$, 259-273, 278, 286

New York Tenement House Department, $4,10,11,85,87,117$, 118

New York Tenement House Law, $10,87,117,118,180,210$

New Zealand, 12, 36, 288, 289

Niagara Falls, N. Y., 77, 142, 143

Niagara Frontier Regional Planning Board, 142, 143

Niles, O., 77

Noise Abatement Commission, 292,293

Nolan, John L., 199

Nolen, John, 157, 159, 160, 164

Non-Partisan League, 240, 241

Norfolk, Va., 77

North Carolina, 29, 33, 34, 159

North Dakota, 37, 205, 240, 241

Norton, Charles D., 144

Norway, 27, 288

Nutley, N. J. Case, 130, 131

Oakland, Calif., 250

Ohio, 32, 129

Oklahoma, 142, 201

Old Hickory, Tenn., 71

Olmsted, F. L., Jr., 159

Onondaga County, N. Y., 142

Ordnance Department, 71

Oregon, 200, 201, 239

Overcrowding, $6,20,22,23,24,27$, $28,34,85,224,233,294$ 


\section{P}

Pacific Coast Shipbuilding Co., 72

Palos Verdes, 158, 159

Panama, Isthmus of, 238

Paris, 93, 228

Passaic, N. J., 167

Paterson, N. J., 167

Paul Laurence Dunbar Apartments, 176, 184, 211, 224-228, 231

Pennsylvania, 20, 114, 129, 143

Pennsylvania Housing Association, 207

Penn, William, 135

Per capita income, 48, 49

Perry, Clarence A., 146, 147, 167

Philadelphia, 4, 5, 38, 42, 53, 88, $89,99,138,143,151,188,190$, 208, 279

Philadelphia, Hog Island, 72

Philadelphia Housing Association, 21, 38, 44, 88, 190

Philadelphịa, Pa. (Oregon Ave.), 77

Phillipsburg, N. J., 63

Pink, Louis H., 12, 173, 177, 213, $214,222,224,228,264,268$

Pittsburgh, 24, 151, 152

Pittsburgh Housing Association, 152

Poland, 92

Pompton Lakes, N. J., 77

Port Jefferson, L. I., 72

Portland, Ore., 22, 99, 115, 158

Portsmouth, N. H., 72, 77

Port Sunlight, 15

Postal Savings, 195, 196

Poured Concrete, 63

Pratt, Ruth S. B., 281

"Present Home Financing Methods," 57, 186, 187

Privies, 5, 20, 21, 24, 30, 34, 35

Prudential Insurance Company, $214,244,245,246,287$

Public Ledger, Philadelphia, 53

Public Utility Societies (British), 15

Puget Sound Navy Yard, Wash., 77

Purdom, C. B., 162
Purdy, Lawson, 275, 276

Pusey and Jones, 72

Putnam County, N. Y., 142

$\mathrm{Q}$

Quantico, Va., 72

Queensboro Corporation, 171

Queens (Borough of, New York City), 38, 110, 111, 119, 146, 175, 208, 210, 214, 262

Quinby, Frank H., 269

Quincy, Mass., 77

Quin, John R., 257

$\mathrm{R}$

Rabinowitz, Aaron, 264, 269, 270

Radburn, N. J., 165-170, 175, 214, 215

R. A. Eastman Inc., 25

Rancho Santa Fe, Calif., 159

Reading, Pa., 37

"Recent Economic Changes in the United States," 2, 3, 27

Reconstruction Com mission (New York State), 85, 86, 202, 203, 260

Regional Planning, 141-148, 160, 282,284

Rensselaer, N. Y., 103, 143

Rent restriction, 95-105, 285

Requisitioning of housing, 74, 96, 100

Ribot law, 14

Richmond (Borough of, New York City), 119, 262

Rickets, 4

Riegelman, Harold, 282

Riis, Jacob, 8

Robinson, Charles Mulford, 136

Rochester, N. Y., 103

Rockefeller Foundation, 158

Rockefeller housing, 176, 184, 210, 221-228

Rockefeller Institute, 222

Rockefeller, John D., Jr., 210, 221 , $222,223,224,225,226,227,268$

Rockefeller Sanitary Commission, 30

Rock Island District, Ill., 77

Rome, 93

Roosevelt, Franklin D., 282 
Rose, David, 271

Rosenwald, Julius, 234, 235

Rothschild Foundation, 228

Rotterdam, 19, 63

Ruhr regional plan, 142

Rumania, 113

Rural housing, 14, 29-35, 246-250, 253,256

Russell Sage Foundation, 144, 147, 167, 221

Russia, 13, 95, 96, 97

S

Sacramento, Calif., 247, 248, 250

Saginaw, Mich., 22

Saint Paul, 22, 37, 114

Saint Louis, 5, 228

San Francisco, 4, 250

Sanitary Housing Company, 11

Sanitary Improvement Company, 11

San Jose, Calif., 250

Santa Barbara, Calif., 142

Satellite Cities, 156-170

Saulsbury Resolution, 99

Savannah, Ga., 72

Schenectady, N. Y., 103, 143

Schmidlapp, J. G., 12, 207

Schnurmacher, Lippman and Charles, 271

Schuchardt, William M., 241

Scotland, 15, 17, 18, 28, 40, 66

Seattle, 37, 42, 99, 151

Serbia, 92

Seven Pines, Va., 77

Shaw, Charles Gray, 277

Shaw, Clifford R., 291

Simkhovitch, Mary K., 281

Single-family and multi-family houses, $41-43$

Single tax, 150

Slum clearance, $13,14,15,17,19$, $22,138,139,244,245,268,274$ $282,285,296,297$

Smith, Alfred E., 21, 85, 87, 102 , $104,112,119,143,202,203,260$, $263,264,268,280$

Soldiers and Sailors Relief Act, 99

South Africa, 12

South America, 12
South Carolina, 32

South Dakota, 201, 202, 239

Spain, 113

Sparrows Point, Md., 72

Springfield, Ill., 24

Springfield, Mass., 140

Springsteen and Goldhammer, 181,183

Stabler, Walter, 212, 214

Standards Recommended for Permanent Industrial Housing Developments, 69

Stanton Homes Corporation, 271

Stein, Clarence S., 86, 166, 202, 215

Sterling, Henry, 238, 239

Stern, Alfred K., 235, 236

Subsidy, 14, 15, 16, 17, 18, 19, 64, $92,94,106,111$

Sunnyside, New York (City Housing Corporation), 165, 175, 176, 214-221

Sun Shipbuilding Company, 72

Super-block. See Radburn

Supply and demand, 43-47, 96, 284

Sutherland, George, 125, 132

Swan, Herbert S., 153

Sweden, 14, 36, 97, 288

Switzerland, 93, 287

\section{$\mathrm{T}$}

Taylor, A. Merritt, 69, 71

Taylor, Clara Sears, 100

Taylor, Robert R., 236

Tax exemption, 38, 64, 106-113, $152,221,255,256,260,262,263$, $264,268,285$

Tenant responsibility, 7, 8

Tennessee, 29

Terry Shipbuilding Company, 72

Texas, 33, 35, 189

Texas Shipbuilding Company, 72

Thomas, Andrew J., 166, 168, 210 , $221,222,225,268,286$

Thomas Garden Apartments, 176, 184, 222, 223, 224

Thomas, Norman M., 278

Thom, D. A., 294, 295

Toledo, 37

Townley, Arthur C., 240 
Town Planning. See City Planning

Traylor Shipbuilding Company, 72

Tri-State Regional Plan, 143

Troy, N. Y., 103, 143

Tuberculosis, 4, 29

Tullytown, Pa., 77

Tulsa, Ponca City and Oklahoma City Regional Planning Commission, 142

\section{U}

Ulm, Germany, 153

Unemployment and housing, 91, 273,297

Union, N. J., 63

United Neighborhood Houses (New York), 22, 53, 120, 121, 224,233

United States Building and Loan League, 191, 192

United States Department of Agriculture, $30,31,32$

United States Department of Commerce, Division of Building and Housing, 61, 128, 129, $131,141,142,186,187,199$

United States Department of Labor, 68

United States Department of Labor, Bureau of Labor Statistics, 55, 57, 106, 173, 174, 175, 206

United States Department of Labor, Children's Bureau, 22, $23,24,33,34,35$

United States Department of Labor, Monthly Labor Review, $42,89,90,173$

United States Housing Corporation, $41,68,71,74,76,78,79,80$, $81,82,99,100,238,274$

United States House of Representatives, 76, 199

United States Senate, 77, 198, 199

United States Shipping Board. See Emergency Fleet Corporation

United States Steel Corporation, $153,154,156$
United States Supreme Court. See Court Decisions

United Workers' Coöperative, $173,175,177,178,179,181,183$

University of California, 247

University of Chicago, 20,233

University of Michigan, 204

University of Nebraska, 30

University of Pennsylvania, 53

Unwin, Raymond, 163, 166

Urban housing, 19-29

Uruguay, 287, 288

Utah, 30

\section{V}

Vancouver, Wash., 72

Veiller, Lawrence, 8, 69, 114, 115, 246, 278, 279, 284

Venice, Calif., 250

Vermont, 30, 32

Veterans' Farm and Home Purchase Act. See California Veterans' Farm and Home Purchase Act

Vienna, 13, 64, 93, 97, 98

Virginia, 99

\section{W}

Waid, D. Everitt, 210

Walker, James J., 117, 118, 263, $276,277,278$

Ward, Florence E., 31

War housing, 66-82, 237, 283

Washington, D. C., 12, 22, 48, 77, $99,100,101,136,138,237,238$, $274,282,285$

Washington Rent Commission, 100,101

Waterbury, Conn., 22, 77

Watertown, N. Y., 77

Watervliet, N. Y., 103

Watts, Calif., 250

Wayne County, Mich., 142

Well Hall, Woolwich, England, 66

Welwyn Garden City, 160, 161, $162,166,220$

Westchester County, 103, 145

Westinghouse E. and M. Co., 72 
Wharton School of Finance, University of Pennsylvania, 53

Wheatley Housing Act, 17

Whipple, George C., 129

Whitaker, Charles Harris, 66

White, Alfred T., 11

White City, 136

Whitman, Marcus, 99

Whitten, Robert, 147

Wichita, Kan., 99

Wilbur, Ray Lyman, 290

Williams, Frank B., 126, 127

Wilmington, Del., 72

Wilson, Woodrow, 68

Wisconsin, 129, 173, 241-243

Wohnbausteur (Vienna dwelling tax), 98

Woodbury, N. J., 77
Wooster, C. M., 248, 249

World's Fair (Chicago), 136

Wright, Henry, 166, 215

Wyandotte, Mich., 72

Wynne, Shirley W., 292, 293

$$
\text { Y }
$$

Yiddische Coöperative Heim Gesellschaft, 175, 177, 179, 183 Yonkers, N. Y., 103

Youngstown, 37

\section{Z}

Zanesville, Ohio, 25

Zoning, 122-134, 137, 145, 147, 151, 161, 284 










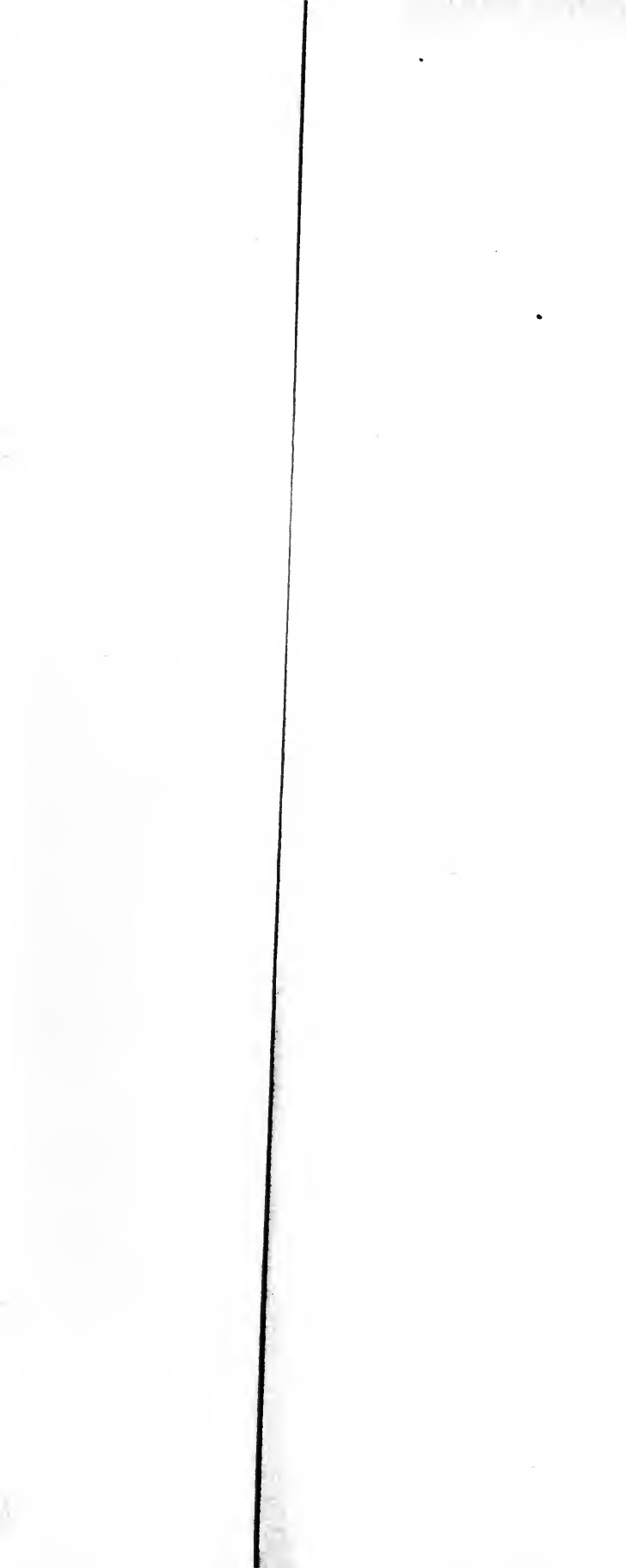


